\title{
Copper-Catalyzed Benzylic C-H Coupling with Alcohols via Radical Relay
}

\author{
Huayou Hu, Si-Jie Chen, Shane Krska, Shannon Stahl
}

Submitted date: 21/05/2019 - Posted date: 22/05/2019

Licence: CC BY-NC-ND 4.0

Citation information: Hu, Huayou; Chen, Si-Jie; Krska, Shane; Stahl, Shannon (2019): Copper-Catalyzed Benzylic C-H Coupling with Alcohols via Radical Relay. ChemRxiv. Preprint.

Cross coupling reactions enable rapid convergent synthesis of diverse molecules and provide the foundation for modern chemical synthesis. The most widely used methods employ sp2-hybridized coupling partners, such as aryl halides or related pre-functionalized substrates. Here, we demonstrate copper-catalyzed oxidative cross-coupling of benzylic $\mathrm{C}-\mathrm{H}$ bonds with alcohols to afford benzyl ethers, enabled by mechanistic insights that led to a novel reductant-based strategy for in situ regeneration of the active copper catalyst. The reactions employ the $\mathrm{C}-\mathrm{H}$ substrate as the limiting reagent and exhibit broad scope with respect to both substrate partners. This approach to direct site-selective functionalization of $\mathrm{sp} 3 \mathrm{C}-\mathrm{H}$ bonds provides the basis for efficient three-dimensional diversification of organic molecules and should find widespread utility in organic synthesis, particularly for medicinal chemistry applications.

File list (3)

Hu Chen Krska Stahl ChemRxiv ms.pdf (1.19 MiB) view on ChemRxiv • download file

Hu Chen Krska Stahl ChemRxiv SI-1.pdf (1.03 MiB) view on ChemRxiv • download file Hu Chen Krska Stahl ChemRxiv SI-2.pdf (8.80 MiB) view on ChemRxiv - download file 


\title{
Copper-catalyzed benzylic $\mathrm{C}-\mathrm{H}$ coupling with alcohols via radical relay
}

\author{
Huayou $\mathrm{Hu}^{1,2,3}$, Si-Jie Chen ${ }^{1,3}$, Shane W. Krska ${ }^{4}$, and Shannon S. Stahl ${ }^{1 *}$ \\ ${ }^{1}$ Department of Chemistry, University of Wisconsin-Madison, 1101 University Avenue, Madison, WI, \\ USA. \\ 2 Jiangsu Key Laboratory for Chemistry of Low-Dimensional Materials, School of Chemistry and \\ Chemical Engineering, Huaiyin Normal University, Huaian, Jiangsu Province, P. R. China \\ ${ }^{3}$ These authors contribute equally. \\ ${ }^{4}$ High-Throughput Experimentation and Lead Discovery Capabilities, Merck \& Co., Inc., Kenilworth, \\ NJ, USA \\ *Correspondence to: stahl@chem.wisc.edu
}

\begin{abstract}
Cross coupling reactions enable rapid convergent synthesis of diverse molecules and provide the foundation for modern chemical synthesis. The most widely used methods employ $\mathrm{sp}^{2}$-hybridized coupling partners, such as aryl halides or related pre-functionalized substrates. Here, we demonstrate copper-catalyzed oxidative cross coupling of benzylic $\mathrm{C}-\mathrm{H}$ bonds with alcohols to afford benzyl ethers, enabled by mechanistic insights that led to a novel reductant-based strategy for in situ regeneration of the active copper catalyst. The reactions employ the $\mathrm{C}-\mathrm{H}$ substrate as the limiting reagent and exhibit broad scope with respect to both substrate partners. This approach to direct site-selective functionalization of $\mathrm{sp}^{3} \mathrm{C}-\mathrm{H}$ bonds provides the basis for efficient threedimensional diversification of organic molecules and should find widespread utility in organic synthesis, particularly for medicinal chemistry applications.
\end{abstract}


Medicinal chemistry efforts in the pharmaceutical industry rely on efficient synthetic methods to prepare molecules with diverse chemical structures and compositions. Coupling methods that unite molecular fragments from two large pools of substrates, such as amide coupling and palladium catalyzed cross coupling, are among the most important and widely used reaction classes in this domain. ${ }^{1,2}$ The prevalent use of $\mathrm{sp}^{2}$-hybridized coupling partners (i.e., aryl, vinyl, acyl electrophiles), however, constrains the topological diversity of molecules that may be accessed and, in many cases, leads to molecules with less desirable physicochemical and other pharmaceutical properties. These limitations have contributed to a growing demand for cross coupling methods involving $\mathrm{sp}^{3}$-hybridized carbon atoms to access molecules with more threedimensional character. ${ }^{3,4} \mathrm{C}\left(\mathrm{sp}^{3}\right)-\mathrm{H}$ bonds adjacent to aromatic and heteroaromatic rings are ubiquitous in key pharmacophores, and methods for selective cross coupling of benzylic $\mathrm{C}-\mathrm{H}$ bonds and other versatile substrate partners (e.g., arylboronic acids, amines, alcohols, Figure 1a) could have a transformative influence on drug discovery. Such reactions would present a wealth of opportunities for elaboration of simple building blocks and pharmaceutical intermediates, as well as late stage functionalization of drug molecules. ${ }^{5}$ The comparatively low bond strength of benzylic $\mathrm{C}-\mathrm{H}$ bonds makes them intrinsically reactive and provides a potential basis for high site selectivity in complex molecules bearing many other $\mathrm{C}-\mathrm{H}$ bonds. Benzylic sites are also notorious metabolic "hot spots" in pharmaceuticals, and their selective substitution has important pharmacological implications. ${ }^{6}$ Here, we report a method for the preparation of benzyl ethers, a prominent motif in pharmaceuticals and bioactive molecules (Figure 1b), via direct oxidative cross coupling of benzylic $\mathrm{C}-\mathrm{H}$ bonds with alcohols. A unique strategy for in situ reductive activation of the catalyst provides the basis for successful reactivity in the present reactions and sets the stage for development of other benzylic $\mathrm{C}-\mathrm{H}$ cross coupling methods. 

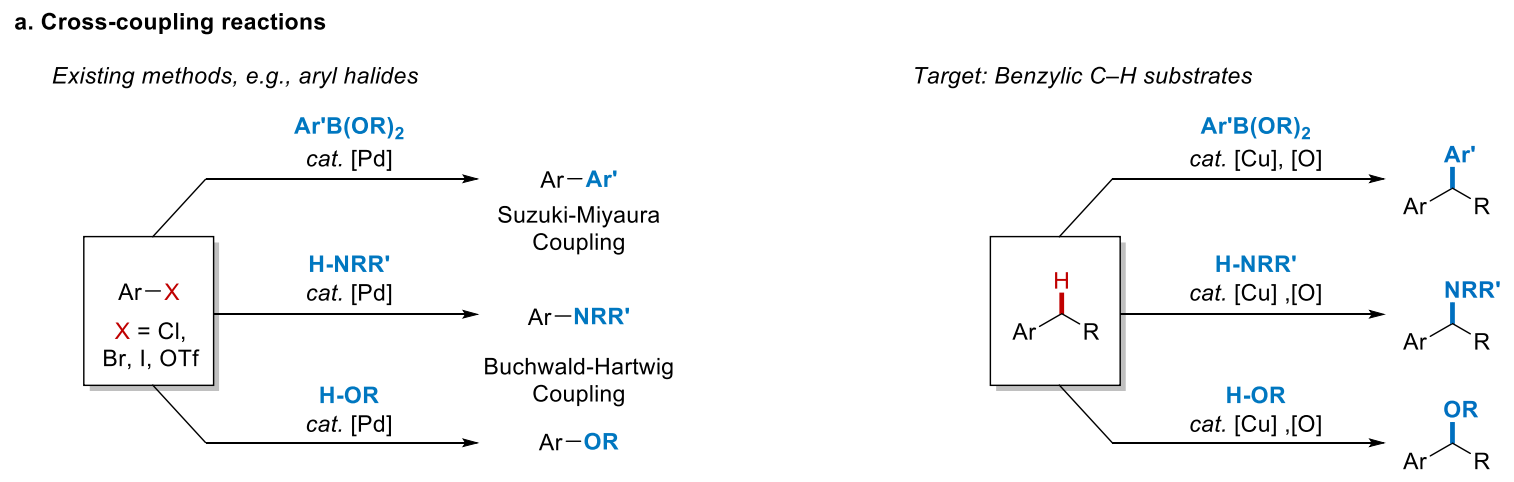

b. Benzylic ethers in pharmaceuticals

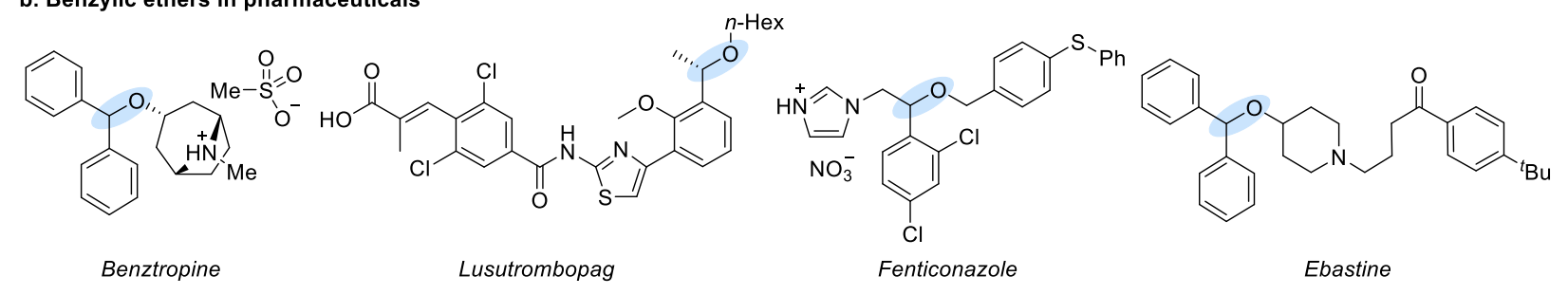

c. Radical relay strategy for cross-coupling of alcohols and benzylic C-H substrates
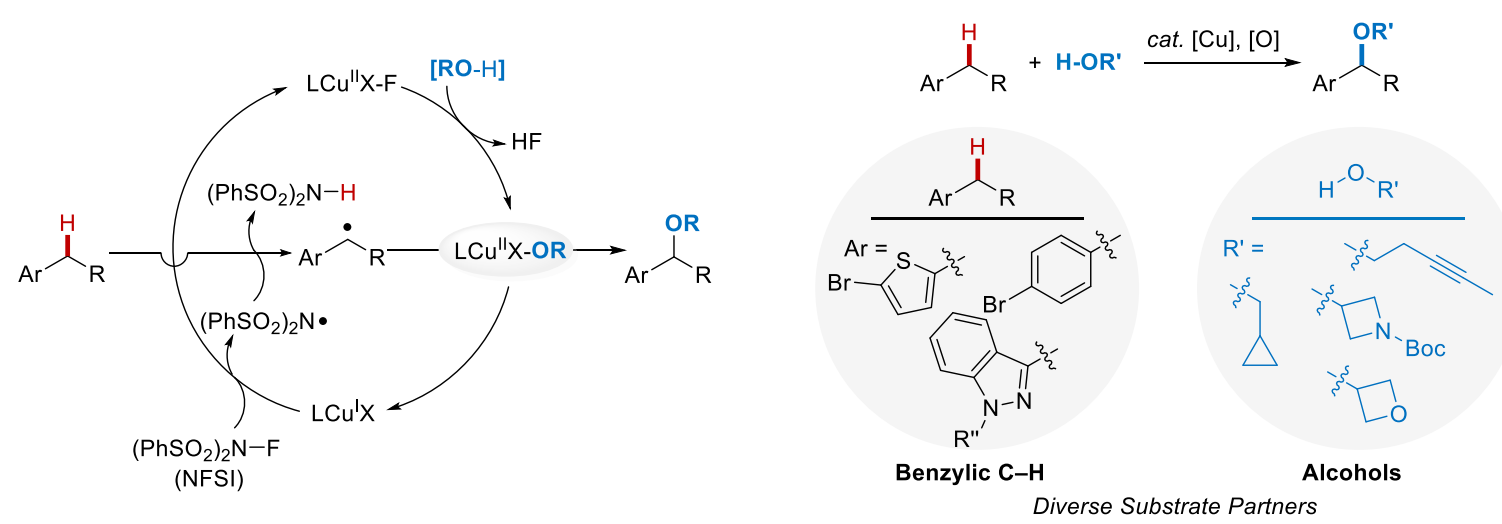

Figure 1. Cross coupling reactions of benzylic $\mathbf{C}-\mathbf{H}$ bonds and alcohols via a radical relay pathway. a, Conceptual similarity between traditional cross coupling reactions of aryl halides and the targeted benzylic $\mathrm{C}-\mathrm{H}$ functionalization reactions. b, Important examples of existing drug molecules containing benzylic ether moieties. c, Proposed radical relay mechanism for benzylic $\mathrm{C}-\mathrm{H}$ etherification enabling the coupling of two diverse pools of substrates.

In recent years, a number of methods have been developed for intermolecular functionalization of $\mathrm{sp}^{3} \mathrm{C}-\mathrm{H}$ bonds that show good site-selectivity, even in the absence of a directing group. Some of the most effective are those that replace the hydrogen atom of a $\mathrm{C}-\mathrm{H}$ bond with a small fragment, for example, oxygenation, ${ }^{7}$ amination, ${ }^{8-10}$ carbene insertion, ${ }^{11}$ halogenation, ${ }^{12,13}$ and various 
pseudohalogenation reactions. ${ }^{14-17}$ Complementary advances have been made in methods for siteselective functionalization of low-cost feedstock molecules, such as alkylarenes, ${ }^{18}, 19$ tetrahydrofuran, ${ }^{20,21}$ or simple hydrocarbons ${ }^{22-24}$ that use excess $\mathrm{C}-\mathrm{H}$ substrate relative to the oxidant and/or functionalization reagent. Collectively, these precedents do not incorporate the characteristics typically associated with "cross coupling" reactions. The most effective cross coupling methods, such as the Suzuki-Miyaura ${ }^{25}$ and Buchwald-Hartwig ${ }^{26,27}$ reactions, have a number of common traits: (a) the most valuable coupling partner is used as the limiting reagent, in ideal cases employing a 1:1 stoichiometry of the two coupling partners, (b) both coupling partners draw from a diverse pool of readily (ideally commercially) available reagents, and (c) the reactions exhibit broad tolerance of the steric, electronic and functional-group properties of both coupling partners.

Alcohols represent an abundant class of building blocks that are widely used as partners in other coupling reactions, including classical methods, such as the Williamson ether synthesis, ${ }^{28}$ in addition to modern catalytic methods. ${ }^{2629}$ Precedents for the direct oxidative coupling of benzylic $\mathrm{C}-\mathrm{H}$ bonds and alcohols, however, are confined to electron-rich arenes that stabilize benzylic cation intermediates, such as those capable of undergoing hydride transfer to DDQ (2,3-dichloro5,6-dicyano-1,4-benzoquinone). ${ }^{30,31} \mathrm{C}-\mathrm{H}$ cleavage via hydrogen-atom transfer (HAT) should be much less sensitive to electronic effects relative to pathways initiated by electron or hydride transfer, ${ }^{32}$ which generate cationic intermediates. Thus, we postulated that a "radical relay" strategy ${ }^{14}$ could provide the basis for selective, broad scope cross coupling of benzylic C-H bonds and alcohols, using the $\mathrm{C}-\mathrm{H}$ substrate as the limiting reagent (Figure 1c). This reaction could be initiated by $\mathrm{Cu}^{\mathrm{I}}$-mediated activation of an oxidant, such as $\mathrm{N}$-fluorobenzenesulfonimide (NFSI), which generates an $\mathrm{N}$-centered radical capable of promoting HAT from the benzylic $\mathrm{C}-\mathrm{H}$ bond. 
The resulting $\mathrm{Cu}^{\mathrm{II}}$ species is then available to mediate coupling of the benzylic radical with the alcohol coupling partner (Figure 1c).

Recent examples of radical relay cyanation, ${ }^{14}$ arylation, ${ }^{33}$ and related functionalization of benzylic $\mathrm{C}-\mathrm{H}$ bonds ${ }^{34-36}$ provided a starting point for this investigation, and we anticipated that reaction conditions similar to these precedents could lead to effective benzylic etherification (Figure 2a). Attempted coupling of 4-ethylbiphenyl and methanol, however, led to negligible yield of the benzylic ether $\mathbf{4}$ with little conversion of the substrate or NFSI (Figure 2a). The good product yields observed from analogous cyanation and arylation reactions suggested that the coupling partner may play an important role in activating the $\mathrm{Cu}$ catalyst. Stoichiometric experiments probing the reaction of $\mathrm{Cu}^{\mathrm{II}}$ with the coupling partners showed that TMSCN and $\mathrm{ArB}(\mathrm{OH})_{2}$ induce rapid reduction of $\mathrm{Cu}^{\mathrm{II}}$ to $\mathrm{Cu}^{\mathrm{I}}$, resulting in the formation of cyanogen ${ }^{37}$ and biaryl. ${ }^{38} \mathrm{In}$ contrast, $\mathrm{MeOH}$ does not reduce $\mathrm{Cu}^{\mathrm{II}}$ under these conditions (Figure $2 \mathrm{~b}$ ).

These observations indicate that the mechanism in Figure 1c is overly simplified and needs to be modified to explain successful reaction with certain coupling partners but not with others. The modified mechanism in Figure $2 \mathrm{c}$ retains reaction of $\mathrm{Cu}^{\mathrm{I}}(\mathbf{A})$ with NFSI to initiate the reaction. This step generates $\mathrm{Cu}^{\mathrm{II}}(\mathbf{B})$ and an $\mathrm{N}$-centered radical (Fig 2c, left cycle). The nitrogen radical can undergo productive reaction with the benzylic $\mathrm{C}-\mathrm{H}$ bond, but it can also react readily with a second equivalent of $\mathrm{Cu}^{\mathrm{I}}$, thereby quenching the radical and converting $\mathrm{Cu}^{\mathrm{I}}$ into a second $\mathrm{Cu}^{\mathrm{II}}$ species $\left(\mathbf{B}^{\prime}\right.$; Fig 2c, right cycle). We postulate that NFSI rapidly oxidizes all of the $\mathrm{Cu}^{\mathrm{I}}$ to $\mathrm{Cu}^{\mathrm{II}}$ when the reaction is initiated, but that certain coupling partners, such as TMSCN or $\operatorname{ArB}(\mathrm{OH})_{2}$, are capable of reducing $\mathrm{Cu}^{\mathrm{II}}$ to regenerate $\mathrm{Cu}^{\mathrm{I}}$ during the course of the reaction (right cycle, red arrow). In these cases, the $\mathrm{Cu}^{\mathrm{I}}$ will react with NFSI to generate an $\mathrm{N}$-centered radical in the absence of a large pool of $\mathrm{Cu}^{\mathrm{I}}$, thereby enabling productive HAT from the benzylic substrate. $\mathrm{MeOH}$ does not readily 
a
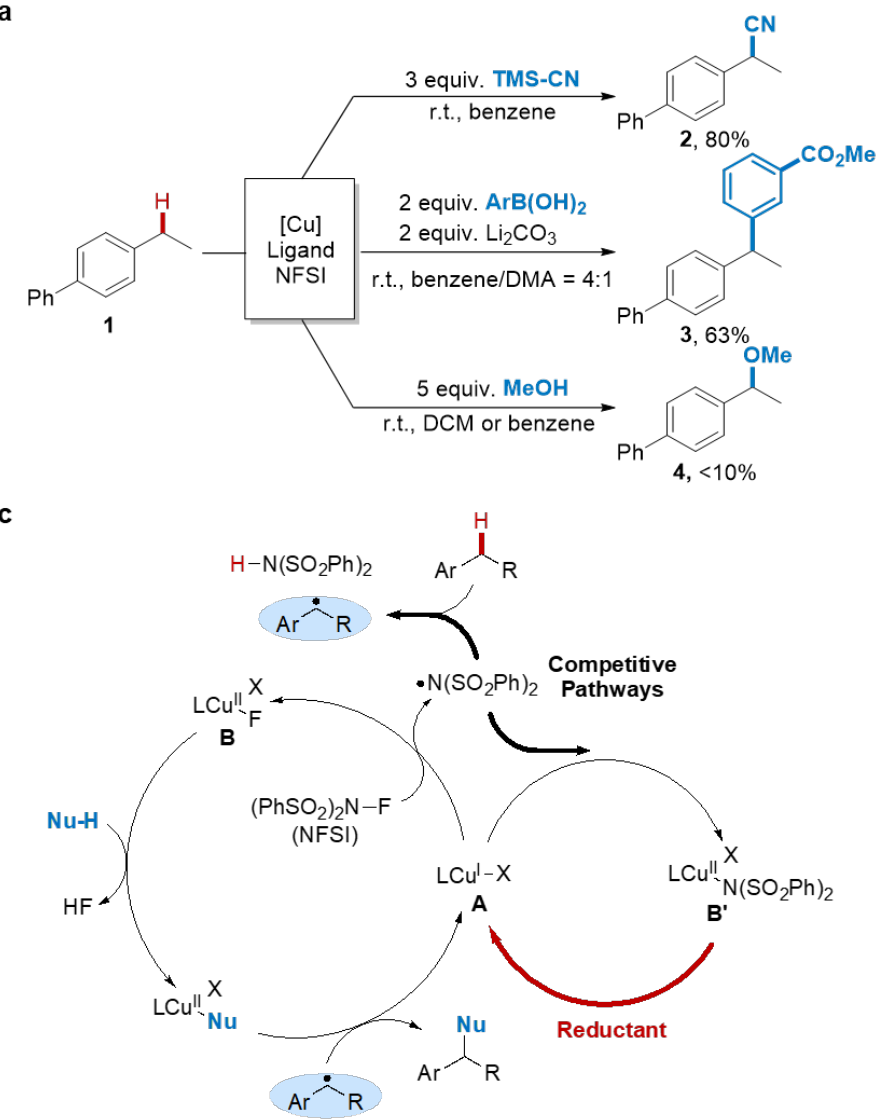

b

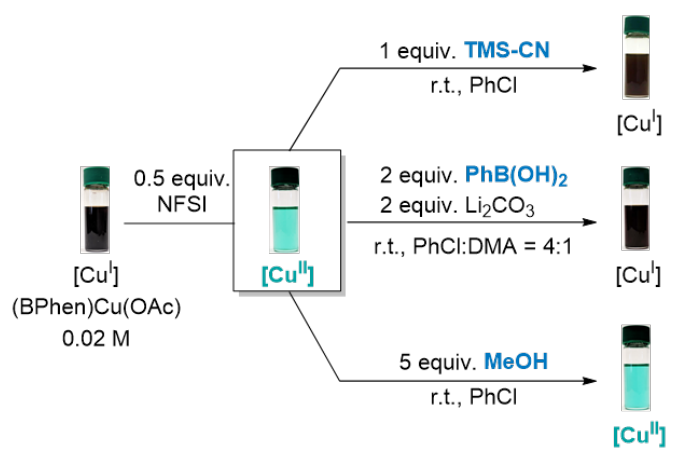

d

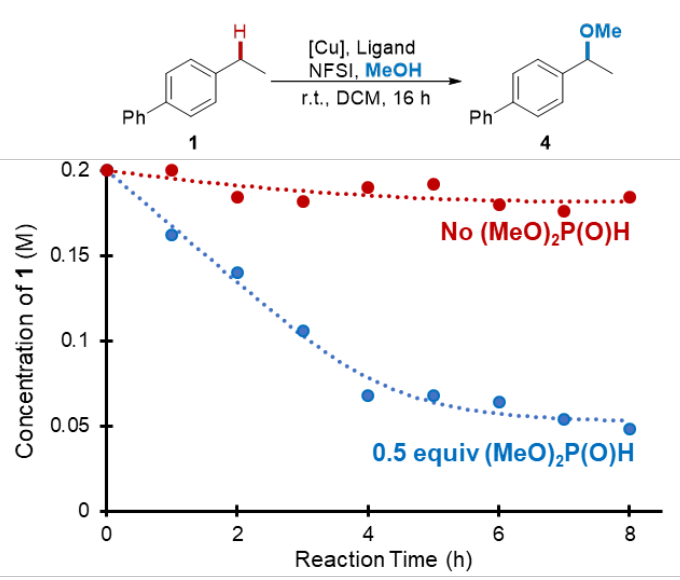

Figure $2 \mathrm{Cu}$-catalyzed benzylic $\mathrm{C}-\mathrm{H}$ functionalization with NFSI as the oxidant. a, $\mathrm{Cu}-$ catalyzed benzylic $\mathrm{C}-\mathrm{H}$ functionalization reactions ${ }^{14,33}$. b, Changes in the $\mathrm{Cu}$ redox state between +1 (brown) and +2 (blue-green) upon addition of NFSI to a solution of the $\mathrm{Cu}^{\mathrm{I}}$ catalyst precursor, followed by addition of cross coupling partners. c, Modified radical relay mechanism (cf. Figure 1d) to account for quenching of the $\mathrm{N}$-centered radical by $\mathrm{Cu}^{\mathrm{I}}$ and regeneration of $\mathrm{Cu}^{\mathrm{I}}$ by a reducing substrate or additive. d, Reaction time course for benzylic etherification conducted in the absence (red) and presence of 0.5 equiv of dimethylphosphite. Reaction conditions: 4-phenylethylbenzene $(0.2 \mathrm{mmol}), \mathrm{NFSI}(0.4 \mathrm{mmol}), \mathrm{MeOH}(1.0 \mathrm{mmol}), \mathrm{CuCl}(0.02 \mathrm{mmol}), 2,2$ '-bioxazoline (0.02 $\mathrm{mmol})$, DCM (1 ml), room temperature.

reduce $\mathrm{Cu}^{\mathrm{II}}$, and the $\mathrm{Cu}$ catalyst will accumulate as $\mathrm{Cu}^{\mathrm{II}}$ (e.g., $\mathbf{B}$ or $\left.\mathbf{B}^{\prime}\right)$. The inability of $\mathrm{Cu}^{\mathrm{II}}$ to react with NFSI under such conditions will cause the reaction to stall. These mechanistic considerations raised the possibility that a reductant could be identified to rescue the catalyst via slow generation of $\mathrm{Cu}^{\mathrm{I}}$ during the reaction. To test this hypothesis, several reductants were tested 
as additives in the etherification reaction with $\mathrm{MeOH}$, including phosphites, silanes, hydrazines, and sodium ascorbate (see Table S3 and S4 in the Supplementary Information for details). Promising reactivity was observed with dimethylphosphite $\left[(\mathrm{MeO})_{2} \mathrm{P}(\mathrm{O}) \mathrm{H}\right]$, and a representative time course of the reaction in Figure $2 d$ illustrates the effect of this additive. In the absence of phosphite, the reaction proceeds to $<10 \%$ conversion of 4-ethylbiphenyl, while inclusion of 0.5 equiv of $(\mathrm{MeO})_{2} \mathrm{P}(\mathrm{O}) \mathrm{H}$ leads to high conversion within $5 \mathrm{~h}$ at room temperature, generating the benzyl methyl ether in 52\% yield (unoptimized). The latter reaction mixture exhibits a blue-green color (cf. Figure $2 \mathrm{~b}$ ), implicating a $\mathrm{Cu}^{\mathrm{II}}$ catalyst resting state, but the phosphite is proposed to serve as a "redox buffer", capable of slowly generating small quantities of reactive $\mathrm{Cu}^{\mathrm{I}}$ to support productive turnover (Figure 2c).

This preliminary result provided the basis for further reaction optimization, and the oxidative coupling of ethylbenzene and methanol was tested with different solvents, ancillary ligands, $\mathrm{Cu}$ sources, and reaction temperatures (see the Supplementary Information for details). A number of monodentate and bidentate ligands were evaluated, and the unsubstituted 2,2'-bioxazoline (biox) ligand led to the best product yields. Use of chiral ligand derivatives did not lead to enantioselectivity under these conditions, but the effectiveness of this ligand class raises prospects for pursuit of this goal in future studies. ${ }^{14,39}$ Inclusion of hexafluoroisopropanol (HFIP) as a cosolvent with dichloromethane (DCM:HFIP = 4:1) led to higher yields and significantly increased the reaction rate, allowing the reaction to proceed at lower temperature $\left(40{ }^{\circ} \mathrm{C}\right) \cdot{ }^{40}$ Under these conditions, reactions of ethylbenzene and 4-ethylbiphenyl, which are electronically similar, generated the 1-methoxyethylbenzene and 4-(1-methoxyethyl)biphenyl in $80 \%$ and $88 \%$ yield, respectively (Figure 3). Use of ethylarenes bearing electron-donating and electron-withdrawing substituents exhibited variable results, with yields ranging from 10-67\% (Figure 3, red bars); 
however, the modular nature of the reaction conditions enabled straightforward optimization of these yields by applying intuitive principles. For example, the electron-rich 4-methoxyethylbenzene is more reactive under the standard conditions and undergoes full conversion with the generation of considerable unidentified side products. Use of more gentle conditions, including removing the co-solvent HFIP, which enhances reactivity, and lowering the temperature from 40 ${ }^{\circ} \mathrm{C}$ to room temperature, led to formation of the desired product in $80 \%$ yield. Substrates bearing electron-withdrawing substituents are somewhat less reactive, as evident from incomplete conversion of the starting material under the original conditions. In these cases, the product yield was improved by raising the reaction temperature to $50{ }^{\circ} \mathrm{C}$ and/or increasing the $\mathrm{Cu}$ catalyst loading to $20 \mathrm{~mol} \%$. After applying these variations, the product yields ranged from $66-88 \%$. Only the 4-cyano derivative, which is very electron deficient, retained a low yield $(10 \%)$ after attempted optimization.
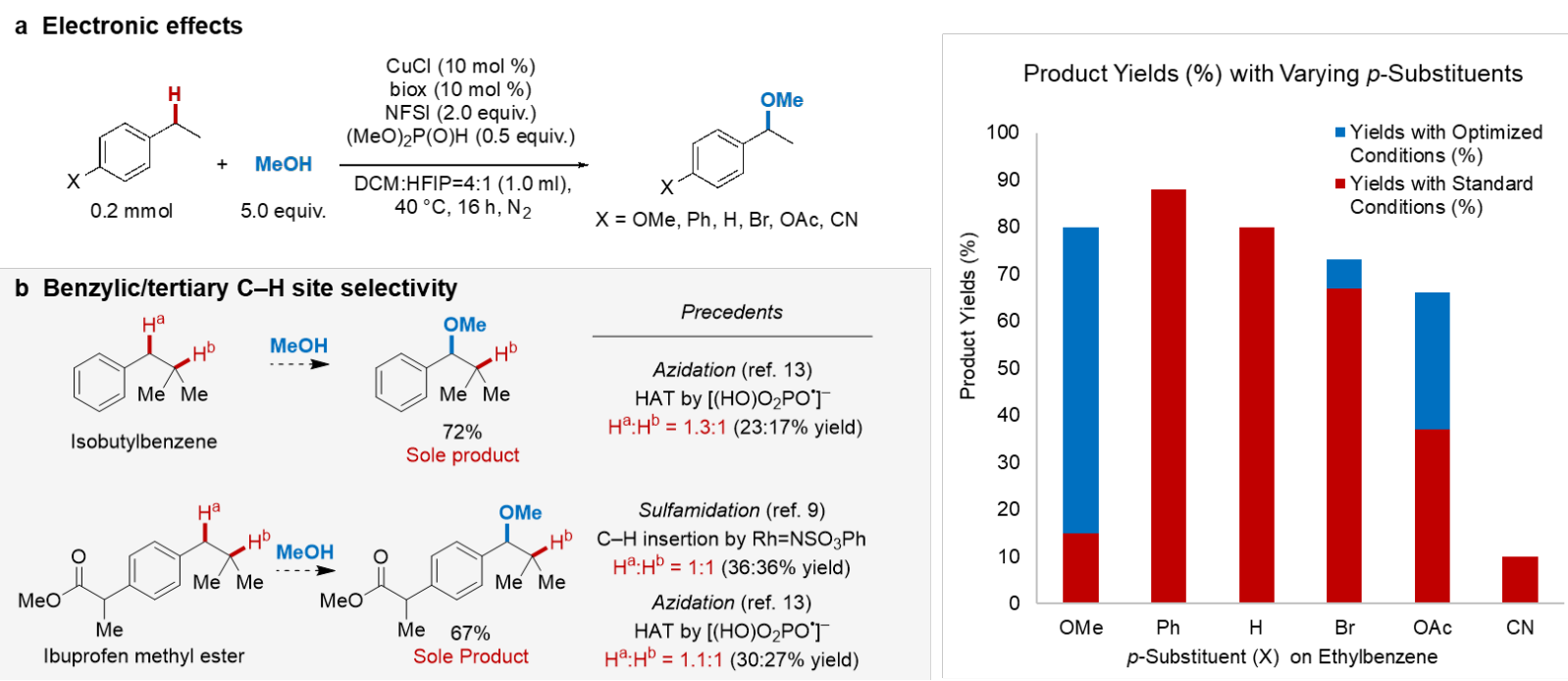

Figure 3 Electronic effects and site selectivity observed in the oxidative coupling of ethylarenes and methanol. a, Results observed from the reaction under standard (red) and individually optimized (blue) conditions ( ${ }^{1} \mathrm{H}$ NMR yields with $\mathrm{CH}_{2} \mathrm{Br}_{2}$ as the internal standard. ${ }^{\text {a }}$ Optimized conditions: $\mathrm{X}=\mathrm{OMe}: 20 \mathrm{~mol} \% \mathrm{Cu} / \mathrm{biox}$ in DCM at r.t.; $\mathrm{X}=\mathrm{Br}: 5 \mathrm{~mol} \% \mathrm{Cu} / \mathrm{biox} ; \mathrm{X}$ $=\mathrm{OAc}: 20 \mathrm{~mol} \% \mathrm{Cu} / \mathrm{biox}$ at $50^{\circ} \mathrm{C}$. b, Analysis of benzylic versus tertiary site selectivity observed in reaction of isobutylbenzene and ibuprofen methyl ester (see Figure 4 for reaction conditions). 
The broad tolerance of arene electronic properties is complemented by nearly exclusive site selectivity. Isobutylbenzene and the ibuprofen methyl ester have been used previously to probe selectivity for benzylic versus tertiary $\mathrm{C}-\mathrm{H}$ activation in photoredox-based azidation ${ }^{13}$ and nitrene insertion $^{9,41}$ reactions. Approximately 1:1 product ratios were observed in the reported reactions with these substrates (Figure 3b). Anticipating that the selectivity depends on the mechanism and reagent involved in the $\mathrm{C}-\mathrm{H}$ cleavage step, we tested these substrates in the present oxidative coupling conditions with methanol. Exclusive reaction at the benzylic position was observed with both substrates (Figure 3b), affording $72 \%$ and $67 \%$ yield of the two methyl ethers, respectively.

Benzylic methoxylation is a valuable transformation in medicinal chemistry, particularly in late-stage functionalization applications, because the introduction of small molecular fragments can significantly influence the activity and pharmacological properties of pharmaceuticals. ${ }^{4,5}$ For example, these groups can modulate the physicochemical characteristics and conformational dynamics of the molecule, introduce hydrogen bond donors/acceptors that can lead to enhanced ligand-target binding interactions, and block reactive sites to slow metabolism and excretion. The methoxy group is an appealing fragment because it has minimal impact on the mass or lipophilicity (i.e., $\log \mathrm{P})$ of the molecule and introduces a potential hydrogen bond acceptor site. ${ }^{5}$

Examination of the substrate scope for benzylic methoxylation began with a number of small molecules and pharmaceutical building blocks as coupling partners (Figure 4). Longer alkyl chains, including those bearing primary alkyl halide substituents are tolerated by the reaction conditions $(\mathbf{1 0 - 1 2}, \mathbf{1 4})$, and good reactivity was also observed with a phenylacetic ester derivative (13). 


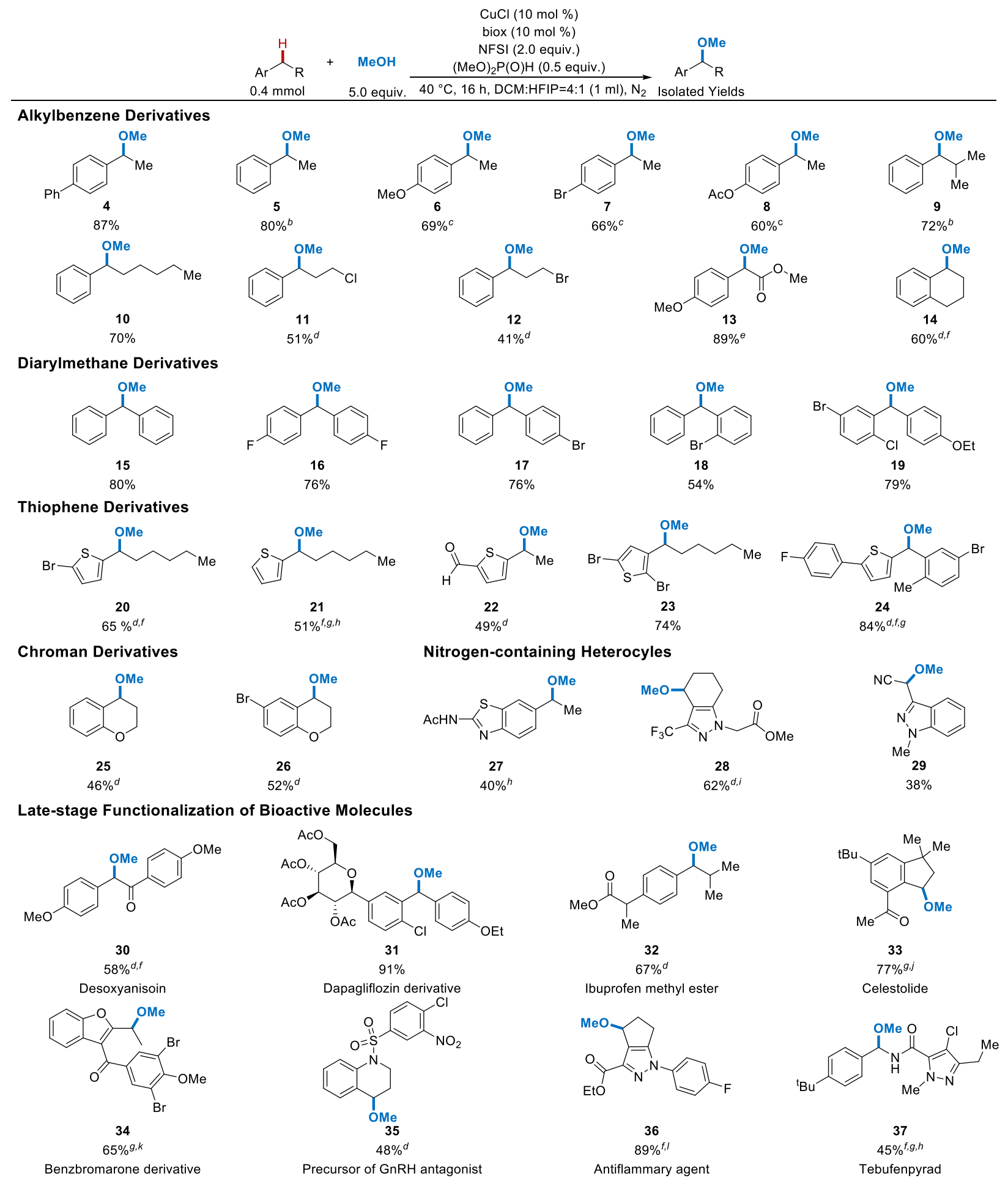

Figure 4. Assessment of different benzylic $\mathrm{C}-\mathrm{H}$ substrates in oxidative cross coupling reactions with methanol. ${ }^{a}$ Isolated yields. ${ }^{b}{ }^{1} \mathrm{H}$ NMR yield; isolated yield unavailable due to compound volatility. ${ }^{\mathrm{c} S e e}$ Figure $3 \mathrm{a}$ for optimized conditions. ${ }^{\mathrm{d}} 15 \mathrm{~mol} \% \mathrm{Cu} / \mathrm{biox} .{ }^{\mathrm{e}}$ Reaction yield at $4 \mathrm{~h} .{ }^{\mathrm{f}}$ At room temperature. ${ }^{\mathrm{g}} \mathrm{DCM}$ as the solvent. ${ }^{\mathrm{h}} 20 \mathrm{~mol} \% \mathrm{Cu} / \mathrm{biox}$. ${ }^{\mathrm{i}}$ Only one regioisomer was observed. ${ }^{j}$ At $30{ }^{\circ} \mathrm{C} .{ }^{k} 30 \mathrm{~mol} \% \mathrm{Cu} /$ biox. ${ }^{1}$ Two regioisomers were observed with a ratio of 9:1. 
Tetralin (14), a substructure present in numerous drugs such as sertraline, treprostinil and rotigotine, underwent effective methoxylation at room temperature. Benzhydryl ethers, including benztropine and ebastine (cf. Figure 1a) represent an important class of antihistamines. ${ }^{42}$ Methyl ethers were obtained in good yield with a series of benzhydryls (15-19) via oxidative cross coupling with methanol. Substrates included the benzhydryl fragment present in dapagliflozin, an approved drug for treatment of type 2 diabetes (cf. 19). This promising reactivity was extended to $\mathrm{C}-\mathrm{H}$ bonds adjacent to medicinally relevant sulfur-, oxygen- and nitrogen-containing heterocycles (20-29). Noteworthy features among these examples include tolerance of (hetero)aryl bromides $(\mathbf{2 0}, \mathbf{2 3}, \mathbf{2 4})$ and a formyl group $(\mathbf{2 2})$, which are versatile functional groups that permit further elaboration of the products. The thiophenylarylmethane core in $\mathbf{2 4}$ is a key fragment in canagliflozin, another commercial drug for type 2 diabetes. Chromans and azoles, which represent important pharmacophores ${ }^{43}$ undergo effective coupling with methanol $(\mathbf{2 5}, \mathbf{2 6}$ and $\mathbf{2 7 - 2 9})$. Some substrates, such as those with pyridine and indole heterocycles, led to lower yields or failed to afford the desired product (see summary provided in Table S5 of the Supplementary Information).

The methoxylation reaction also proceeded effectively in the late-stage functionalization of a number of pharmaceuticals and related bioactive molecules, including the immunosuppressant desoxyanisoin (30); ${ }^{44}$ the natural product celestolide (33); a precursor to a GnRH antagonist (35); ${ }^{45}$ a cyclopentapyrazolyl anti-inflammatory and anti-allergy agent (36); ${ }^{46}$ and the insecticide, tebufenpyrad (37). Each of these underwent effective coupling with methanol and exhibited excellent selectivity for reaction at the benzylic position. For example, no products were obtained from methoxylation of the aliphatic $\mathrm{C}-\mathrm{H}$ bond next to the nitrogen atom in $\mathbf{3 5}$ or adjacent to the alkoxy oxygen atoms in 30. Good selectivity was also observed between the two similar cyclopentyl $\mathrm{C}-\mathrm{H}$ positions in $\mathbf{3 6}$. The 9:1 ratio favoring the product shown over the alternate 
regioisomer probably arises from higher reactivity at the more electron-rich site. Free -OH groups, such as those present in a sugar fragment of dapagliflozin (anti-diabetic), a carboxylic acid of ibuprofen (anti-inflammatory), and a phenol in benzbromarone (xanthine oxidase inhibitor ${ }^{47}$ ) interfere with the etherification reaction, but successful reactivity proceeds when these groups are suitably protected $(\mathbf{3 1}, \mathbf{3 2}, \mathbf{3 4})$.

The potential utility of this method for medicinal chemistry library synthesis is especially evident from assessment of the $\mathrm{C}-\mathrm{H}$ cross coupling reaction with diverse alcohols. The thiophenecontaining fragment of canagliflozin was selected as a representative, moderately complex core structure for these studies (Figure 5). Initial tests employing 2-chloroethanol as the coupling partner led to two products, the desired 2-chloroethyl ether in addition to the methyl ether product in $64 \%$ and $18 \%$ yields, respectively. The latter product derives from participation of the methoxy group from the $(\mathrm{MeO})_{2} \mathrm{P}(\mathrm{O}) \mathrm{H}$ reductant in the reaction. Reevaluation of other phosphites showed that this side product formation could be nearly eliminated $(<2 \%)$ by using diisopropyl phosphite (see Table S6 in the Supplementary Information for details). This insight was then implemented in reactions with numerous other alcohol coupling partners. Several 2-substituted ethanol derivatives, including those bearing chloro, methoxy, BocNH (Boc = tert-butyloxycarbonyl), alkynyl, vinyl, naphthyl, and benzyl ether substituents (38-44), were effective in the reaction, in most cases affording product in good-to-excellent yields. Only the alkene-containing substrate 42 led to a relatively low yield, possibly reflecting competitive reaction with the allylic $\mathrm{C}-\mathrm{H}$ bonds. The presence of benzylic $\mathrm{C}-\mathrm{H}$ bonds in the alcohols $\mathbf{4 3}$ and $\mathbf{4 4}$ did not interfere with successful reactivity. Both afforded the desired product in good yield. Expanding on this compatibility, a series of ortho-, meta-, and para-substituted benzyl alcohols with different electronic and steric 


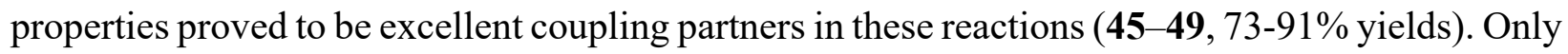
small amounts of benzaldehyde by-product were observed in these reactions.

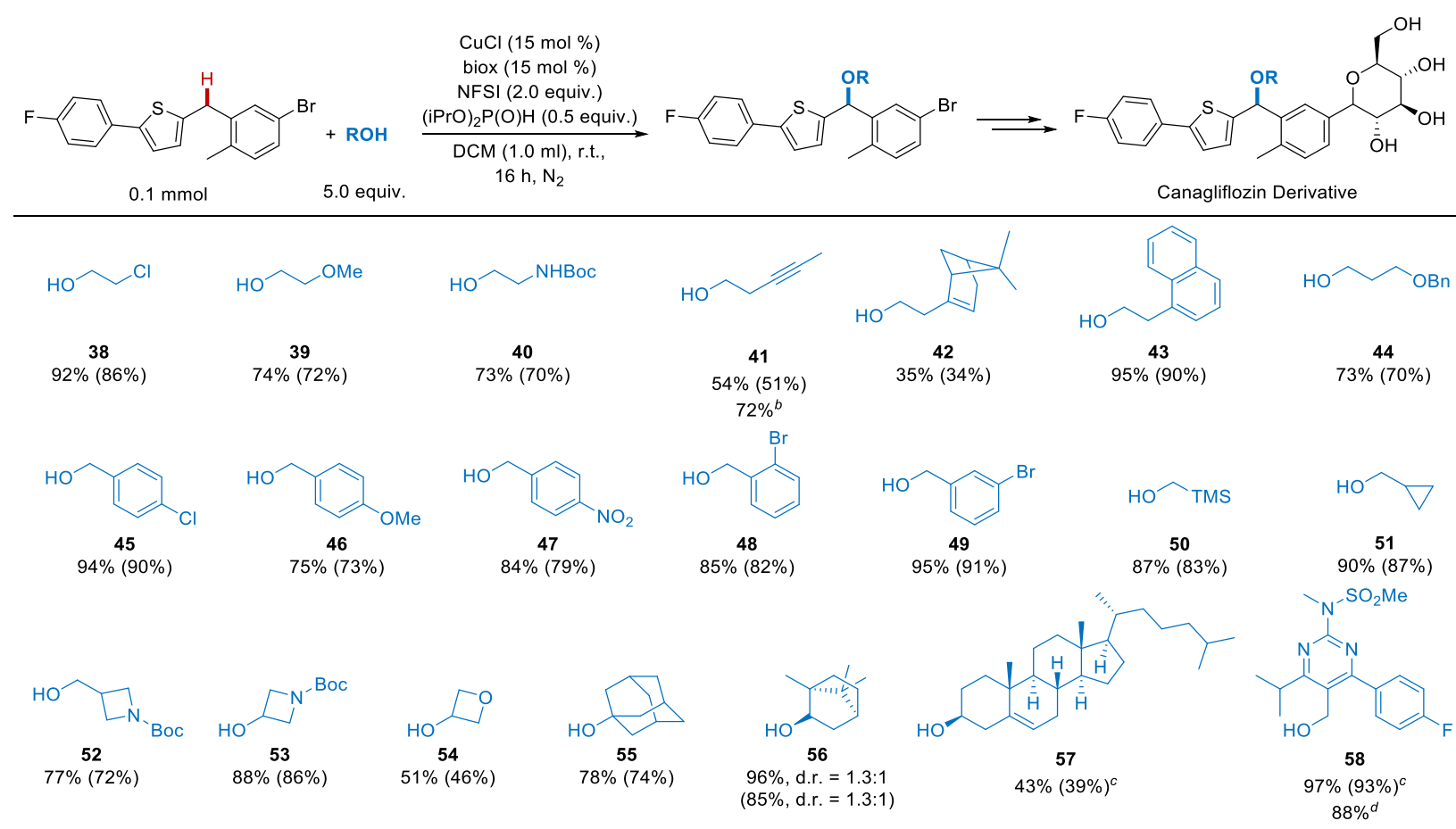

Figure 5. Assessment of different alcohols in benzylic $\mathrm{C}-\mathrm{H}$ etherification reactions. a Calibrated ${ }^{1} \mathrm{H}$ NMR yields using dibromomethane as the internal standard (isolated yields in parentheses). ${ }^{\mathrm{b}} 30 \mathrm{~mol} \% \mathrm{Cu} / \mathrm{biox} .{ }^{\mathrm{c}}$ Conducted with 3.0 equiv. alcohol. ${ }^{\mathrm{d}}$ Conducted with 1.1 equiv. alcohol.

Other aliphatic alcohols were also successful, including trimethylsilylmethanol, cyclopropylmethanol $(\mathbf{5 0}, \mathbf{5 1})$, and several oxetane and azetidine analogs (52-54). Small groups such as these are increasingly featured in preclinical and clinical drug candidates, ${ }^{48,49}$ and the cross coupling of benzylic $\mathrm{C}-\mathrm{H}$ bonds and alcohols provides a compelling strategy to introduce these units. The effectiveness of adamantanol and (-)-borneol $(\mathbf{5 5}, \mathbf{5 6})$ showed that sterically hindered alcohols can serve as effective coupling partners. Finally, the method proved effective with complex alcohols, including cholesterol (57) and a pyrimidinylmethanol precursor to rosuvastatin 
(58). The latter reaction was demonstrated on $>1 \mathrm{~g}$ scale ( $91 \%$ yield, $1.3 \mathrm{~g}$ ) and was also successful with only 1.1 equiv of $\mathbf{5 8}(88 \%$ yield).

Collectively, these results demonstrate a new class of highly selective, non-directed $\mathrm{C}-\mathrm{H}$ cross coupling reactions that create opportunities for efficient synthesis of novel molecules and diversification of chemical structures, ranging from simple aromatic and heteroaromatic building blocks to complex pharmacophores and existing drug molecules. Prominent features of these reactions include good product yields, ability to use the benzylic substrate as the limiting reagent, high benzylic site selectivity, and access to a broad substrate scope with respect to both reaction partners. Mechanistic insights set the stage for these results by revealing that traditional reaction conditions lead to accumulation of the catalyst in an inactive $\mathrm{Cu}^{\mathrm{II}}$ state, and the key breakthrough arose from the discovery that the addition of phosphite allows for slow in situ reduction of $\mathrm{Cu}^{\mathrm{II}}$ to $\mathrm{Cu}^{\mathrm{I}}$ during the course of the reaction. We anticipate that this "redox buffering" strategy will not be unique to this reaction class, but it will lead to the discovery and development of other radical relay

$\mathrm{C}-\mathrm{H}$ cross coupling methods with potential for widespread impact in medicinal chemistry and organic synthesis.

\section{Supplementary Information.}

Experimental procedures for preparation, optimization conditions, characterization data and NMR spectra of compounds (pdf).

\section{Acknowledgements.}

We thank Bing Li (Merck \& Co., Inc., Kenilworth, NJ, USA) for technical assistance. This work was supported by the NIH (R01 GM126832, to S.S.S.), Jiangsu Province (BK20161307 and “333” Talents Project, to H.H.) and Huaiyin Normal University (JSKC18014, to H.H.), and Merck \& 
Co., Inc., Kenilworth, NJ, USA (S.W.K.; travel funds to S.C.). Spectroscopic instrumentation was supported by a gift from Paul. J. Bender, the NSF (CHE-1048642), and the NIH (1S10 OD020022$1)$.

\section{References.}

1. Brown, D. G. \& Boström, J. Analysis of past and present synthetic methodologies on medicinal chemistry: where have all the new reactions gone?: miniperspective. J. Med. Chem. 59, 4443-4458 (2016).

2. Boström, J., Brown, D. G., Young, R. J. \& Keserü, G. M. Expanding the medicinal chemistry synthetic toolbox. Nat. Rev. Drug Disc. 17, 709-727 (2018).

3. Lovering, F., Bikker, J. \& Humblet, C. Escape from flatland: increasing saturation as an approach to improving clinical success. J. Med. Chem. 52, 6752-6756 (2009).

4. Blakemore, D. C. et al. Organic synthesis provides opportunities to transform drug discovery. Nat. Chem. 10, 383-394 (2018).

5. Cernak, T., Dykstra, K. D., Tyagarajan, S., Vachal, P. \& Krska, S. W. The medicinal chemist's toolbox for late stage functionalization of drug-like molecules. Chem. Soc. Rev. 45, 546-576 (2016).

6. Thompson, T. N. Optimization of metabolic stability as a goal of modern drug design. Med. Res. Rev. 21, 412-449 (2001).

7. White, M. C., Zhao, J. Aliphatic C-H oxidations for late-stage functionalization. J. Am. Chem. Soc. 140, 13988-14009 (2018).

8. Muniz, K. \& Bosnidou, A. E. Intermolecular radical $\mathrm{C}\left(\mathrm{sp}^{3}\right)-\mathrm{H}$ amination under iodine catalysis. Angew. Chem. Int. Ed. (2019). doi:10.1002/anie.201901673. 
9. Chiappini, N., Mack, J. \& Du Bois, J. Intermolecular $\mathrm{C}\left(\mathrm{sp}^{3}\right)-\mathrm{H}$ amination of complex molecules. Angew. Chem. Int. Ed. 57, 4956-4959 (2018).

10. Clark, J. R., Feng, K., Sookezian, A. \& White, M. C. Manganese-catalysed benzylic C(sp $\left.{ }^{3}\right)_{-}$ H amination for late-stage functionalization. Nat. Chem. 10, 583-591 (2018).

11. Davies, H. M. L. \& Morton, D. Guiding principles for site selective and stereoselective intermolecular $\mathrm{C}-\mathrm{H}$ functionalization by donor/acceptor rhodium carbenes. Chem. Soc. Rev. 40, 1857 (2011).

12. Liu, W., Groves, J. T. Manganese catalyzed C-H halogenation. Acc. Chem. Res. 48, 1727$1735(2015)$.

13. Margrey, K. A., Czaplyski, W. L., Nicewicz, D. A. \& Alexanian, E. J. A general strategy for aliphatic $\mathrm{C}-\mathrm{H}$ functionalization enabled by organic photoredox catalysis. J. Am. Chem. Soc. 140, 4213-4217 (2018).

14. Zhang, W. et al. Enantioselective cyanation of benzylic $\mathrm{C}-\mathrm{H}$ bonds via copper-catalyzed radical relay. Science 353, 1014-1018 (2016).

15. Sharma, A. \& Hartwig, J. F. Metal-catalysed azidation of tertiary C-H bonds suitable for late-stage functionalization. Nature 517, 600-604 (2015).

16. Huang, X. \& Groves, J. T. Taming azide radicals for catalytic C-H azidation. ACS Catal. 6 , $751-759$ (2016).

17. Czaplyski, W. L., Na, C. G. \& Alexanian, E. J. C-H xanthylation: A synthetic platform for alkane functionalization. J. Am. Chem. Soc. 138, 13854-13857 (2016).

18. Vasilopoulos, A., Zultanski, S. L. \& Stahl, S. S. Feedstocks to pharmacophores: Cucatalyzed oxidative arylation of inexpensive alkylarenes enabling direct access to diarylalkanes. J. Am. Chem. Soc. 139, 7705-7708 (2017). 
19. Wang, Z., Zheng, Z., Xu, X., Mao, J. \& Walsh, P. J. One-pot aminobenzylation of aldehydes with toluenes. Nat. Commun. 9, (2018).

20. Shield, B. J., Doyle, A. G. Direct $\mathrm{C}\left(\mathrm{sp}^{3}\right)-\mathrm{H}$ cross coupling enabled by catalytic generation of chlorine radicals. J. Am. Chem. Soc. 138, 12719-12722 (2016).

21. Heitz, D. R., Tellis, J. C. \& Molander, G. A. Photochemical nickel-catalyzed C-H arylation: synthetic scope and mechanistic investigations. J. Am. Chem. Soc. 138, 12715-12718 (2016).

22. Perry, I. B. et al. Direct arylation of strong aliphatic C-H bonds. Nature 560, 70-75 (2018).

23. Liu, D. et al. Nickel-catalyzed selective oxidative radical cross-coupling: an effective strategy for inert $\mathrm{Csp}^{3}-\mathrm{H}$ functionalization. Org. Lett. 17, 998-1001 (2015).

24. Tran, B. L., Li, B., Driess, M. \& Hartwig, J. F. Copper-catalyzed intermolecular amidation and imidation of unactivated alkanes. J. Am. Chem. Soc. 136, 2555-2563 (2014).

25. Miyaura, N. \& Suzuki, A. Palladium-catalyzed cross-coupling reactions of organoboron compounds. Chem. Rev. 95, 2457-2483 (1995).

26. Ruiz-Castillo, P. \& Buchwald, S. L. Applications of palladium-catalyzed C-N crosscoupling reactions. Chem. Rev. 116, 12564-12649 (2016).

27. Hartwig, J. F. Transition metal catalyzed synthesis of arylamines and aryl ethers from aryl halides and triflates: scope and mechanism. Angew. Chem. Int. Ed. 37, 2046-2067 (1998).

28. Williamson, A. Theory of ætherification. Philos. Mag. 37, 350-356 (1850).

29. Enthaler, S. \& Company, A. Palladium-catalysed hydroxylation and alkoxylation. Chem. Soc. Rev. 40, 4912-4924 (2011).

30. Chapman, L. M., Beck, J. C., Wu, L. \& Reisman, S. E. Enantioselective total synthesis of (+)-psiguadial B. J. Am. Chem. Soc. 138, 9803-9806 (2016). 
31. Maloney, D. J., Chen, S. \& Hecht, S. M. Stereoselective synthesis of the atropisomers of myristinin B/C. Org. Lett. 8, 1925-1927 (2006).

32. Rafiee, M., Wang, F., Hruszkewycz, D. P. \& Stahl S. S. N-Hydroxyphthalimide-mediated electrochemical iodination of methylarenes and comparison to electron-transfer-initiated C-H Functionalization. J. Am. Chem. Soc. 140, 22-25 (2018).

33. Zhang, W., Chen, P. \& Liu, G. Copper-catalyzed arylation of benzylic C-H bonds with alkylarenes as the limiting reagents. J. Am. Chem. Soc. 139, 7709-7712 (2017).

34. Ni, Z. et al. Highly Regioselective copper-catalyzed benzylic C-H amination by NFluorosulfonimide. Angew. Chem. Int. Ed. 51, 1244-1247 (2012).

35. Yang, H. et al. Silver-promoted oxidative benzylic C-H trifluoromethoxylation. Angew. Chem. Int. Ed. 57, 13266-13270 (2018).

36. Xiao, H. et al. Copper-catalyzed late-stage benzylic C(sp3)-H trifluoromethylation. Chem (2019). doi:10.1016/j.chempr.2019.02.006.

37. Janz, G. J. Cyanogen. Inorg. Synth. 5, 43-48 (1957).

38. Demir, A. S., Reis, Ö. \& Emrullahoglu, M. Role of copper species in the oxidative dimerization of arylboronic acids: synthesis of symmetrical biaryls. J. Org. Chem. 68, 10130-10134 (2003).

39. Liu, G., Zhang, W., Wu, L. \& Chen, P. Enantioselective arylation of benzylic C-H bonds via copper-catalyzed radical relay. Angew. Chem. Int. Ed. (2019). doi:10.1002/anie.201902191

40. Colomer, I., Chamberlain, A. E. R., Donohoe, T. J. Hexafluoroisopropanol as a highly versatile solvent. Nat. Rev. Chem. 1, 0088 (2017).

41. Bess, E. N. et al. Analyzing site selectivity in $\mathrm{Rh}_{2}(\text { esp })_{2}$-catalyzed intermolecular $\mathrm{C}-\mathrm{H}$ amination reactions. J. Am. Chem. Soc.136, 5783-5789 (2014). 
42. Loew, E. R., MacMillan, R. \& Kaiser, M. E. The anti-histamine properties of benadryl, $\beta$ dimethylaminoethyl benzhydryl ether hydrochloride. J. Pharmacol. Exp. Ther. 86, 229 (1946).

43. Du, L. et al. Molecular hybridization, synthesis, and biological evaluation of novel chroman IKr and IKs dual blockers. Bioorg. Med. Chem. Lett. 19, 1477-1480 (2009).

44. Rhodes, J. R. Immunopotentiatory agents and physiologically acceptable salts thereof. US Patent US5508310A (1996).

45. Fushimi, N., Yonekubo, S., Ohno, K., Miyagi, T. Nitrogen-containing fused ring derivatives, pharmaceutical compositions containing them and their pharmaceutical use. JP Patent 5308342B2 (2008).

46. Upjohn Co. Cyclopentapyrazole and tetrahydroindazole compounds. WO Patent Appl. 8607357 (1986).

47. Schepers, G. Benzbromarone therapy in hyperuricaemia; comparison with allopurinol and probenecid. J. Int. Med. Res. 9, 511-515 (1981).

48. Talele, T. T. The 'cyclopropyl fragment' is a versatile player that frequently appears in preclinical/clinical drug molecules. J. Med. Chem. 59, 8712-8756 (2016).

49. Wuitschik, G. et al. Oxetanes in drug discovery: structural and synthetic insights. J. Med. Chem. 53, 3227-3246 (2010). 
Supplementary Information

\title{
Copper-catalyzed benzylic $\mathbf{C}-\mathbf{H}$ coupling with alcohols via radical relay
}

\author{
Huayou $\mathrm{Hu}^{1,2,3}$, Si-Jie Chen ${ }^{1,3}$, Shane W. Krska ${ }^{4}$ and Shannon S. Stahl ${ }^{1 *}$ \\ ${ }^{1}$ Department of Chemistry, University of Wisconsin-Madison, 1101 University Avenue, Madison, WI, USA. \\ ${ }^{2}$ Jiangsu Key Laboratory for Chemistry of Low-Dimensional Materials, School of Chemistry and Chemical \\ Engineering, Huaiyin Normal University, Huaian, Jiangsu Province, P. R. China \\ ${ }^{3}$ These authors contribute equally. \\ ${ }^{4}$ Chemistry Capabilities and Screening, Merck Sharp \& Dohme Corporation, Kenilworth, New Jersey, USA \\ *Correspondence to: stahl@,chem.wisc.edu
}

\section{Table of Contents}

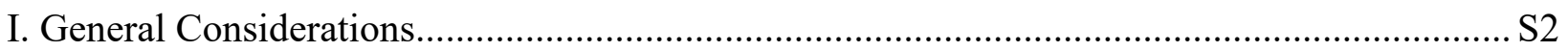

II. Experimental Procedures for Preparations of Compounds ............................................... S2

III. Optimization of the Reaction Conditions .................................................................. S5

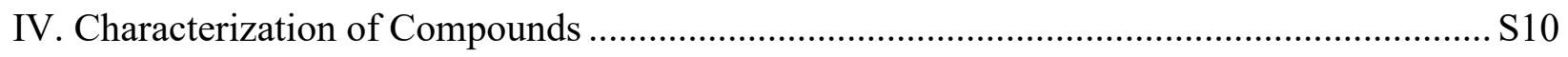

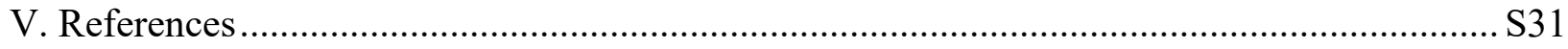

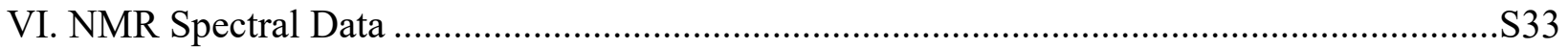




\section{General Considerations}

All reagents were purchased and used as received unless otherwise noted. $\mathrm{Cu}$ salts were purchased from Aldrich. Benzylic C-H substrates were purchased from Oakwood Chemicals, Combi-Blocks, Chem-Impex, Alfa Aesar, TCI America, Ark Pharm, Enamine, AstaTech or Aldrich. With the exception of ligand L8 (cf. Table S1), which was prepared by a literature protocol ${ }^{1}$, ligands were purchased from Aldrich or TCI America. N-Fluorobenzenesulfonimide (NFSI) was purchased from Combi-Blocks and Ark Pharm. Methanol was purchased from Aldrich and Macron Fine Chemicals. Dialkyl phosphites were purchased from Aldrich, TCI America, Alfa Aesar and Oakwood Chemicals. All the reagents were used without further purification.

${ }^{1} \mathrm{H}$ and ${ }^{13} \mathrm{C}$ NMR spectra were recorded on Bruker $400 \mathrm{MHz}$ or Bruker $500 \mathrm{MHz}$ spectrometers and chemical shifts are reported in parts per million (ppm). ${ }^{1} \mathrm{H}$ NMR spectra were referenced to tetramethylsilane at $0.00 \mathrm{ppm}$ and ${ }^{13} \mathrm{C}$ NMR spectra were referenced to $\mathrm{CDCl}_{3}$ at $77.16 \mathrm{ppm}$. Chromatography was performed using either a Combi-flash ${ }^{\circledR}$ with reusable $24 \mathrm{~g}$ or $12 \mathrm{~g}$ Combiflash gold $\AA$ cartridges, or a Biotage Isolera One ${ }^{\circledR}$ with reusable 25 g SNAP Ultra ${ }^{\circledR}$ cartridges or standard silica cartridges. High-resolution mass spectra were obtained using a Thermo Q Exactive $^{\mathrm{TM}}$ Plus (ESI or ASAP-MS) by the mass spectrometry facility at the University of Wisconsin (funded by NIH grant: 1S10OD020022-1).

\section{Experimental Procedures for Preparations of Compounds}

General Procedure (I) for Methoxylation of Benzylic C-H Substrates (pressure tube) Copper(I) chloride (2.0 mg, $0.020 \mathrm{mmol}, 10 \mathrm{~mol} \%$ ), 4,4',5,5'-tetrahydro-2,2'-bioxazole ( $2.8 \mathrm{mg}$, $0.020 \mathrm{mmol}, 10 \mathrm{mo} \%$ ), NFSI (126.1 mg, $0.40 \mathrm{mmol}, 2.0$ equiv.) and benzylic substrate (if solid, $0.20 \mathrm{mmol}, 1.0$ equiv.) were added to a pressure tube under air, and then the tube was moved to a glove box. Solvent (1.0 mL), benzylic substrate (if liquid, $0.20 \mathrm{mmol}, 1.0$ equiv.), methanol (42 $\mu \mathrm{L}, 1.0 \mathrm{mmol}, 5.0$ equiv.) and dimethyl phosphonate $(9.5 \mu \mathrm{L}, 0.10 \mathrm{mmol}, 0.5$ equiv.) were added to the tube. The tube was sealed in the glove box and taken out to a hot plate. The sealed tube was heated at $40^{\circ} \mathrm{C}$ with stirring for $16 \mathrm{~h}$. When the reaction finished, the mixture was cooled down to room temperature, poured into water and extracted with $\mathrm{CHCl}_{3}(10 \mathrm{~mL} \times 3)$. The organic layers were combined and washed by saturated sodium bicarbonate, brine and dried with $\mathrm{Na}_{2} \mathrm{SO}_{4}$ and filtered. Then the mixture was evaporated under vacuum and the crude mixture was purified by automated flash chromatography (silica gel, eluted by pentane:ethyl acetate $=20: 1$ to $4: 1$ ).

General Procedure (II) for Methoxylation of Benzylic C-H Substrates (glass vial) Copper(I) chloride (2.0 mg, $0.020 \mathrm{mmol}, 10 \mathrm{~mol} \%)$, 4,4',5,5'-tetrahydro-2,2'-bioxazole (2.8 mg, $0.020 \mathrm{mmol}, 10 \mathrm{~mol} \%)$, NFSI (126.1 mg, $0.40 \mathrm{mmol}, 2.0$ equiv.) and benzylic substrate (if solid, $0.20 \mathrm{mmol}, 1.0$ equiv.) were added under air to a $4 \mathrm{ml}$ vial containing a magnetic stir bar. Then the vial was capped with a pierceable Teflon cap. A needle was pierced through the cap to facilitate exchange of the vial headspace with the atmosphere. Then the vial was moved into a glove box, 
through three vacuum-nitrogen-backfill cycles. The needle was removed, and the vial was taken out of the glove box (now sealed under an inert gas). Solvent $(1.0 \mathrm{~mL})$, benzylic substrate (if liquid, $0.20 \mathrm{mmol}, 1.0$ equiv. $)$, methanol $(42 \mu \mathrm{L}, 1.0 \mathrm{mmol}, 5.0$ equiv. $)$ and dimethyl phosphonate $(9.5 \mu \mathrm{L}$, $0.10 \mathrm{mmol}, 0.5$ equiv.) were added into the vial by injection through the cap. The sealed vial was heated at $40{ }^{\circ} \mathrm{C}$ and stirred for $16 \mathrm{~h}$. When the reaction finished, the mixture was cooled down to room temperature and triethylamine $(140 \mu \mathrm{L}, 1.0 \mathrm{mmol}, 5.0$ equiv.) was added to quench any unreacted NFSI. Then the mixture was evaporated under vacuum and the crude mixture was purified by automated flash chromatography (silica gel, eluted by pentane:ethyl acetate $=20: 1$ to $4: 1)$.

Procedure for the gram scale experiment.
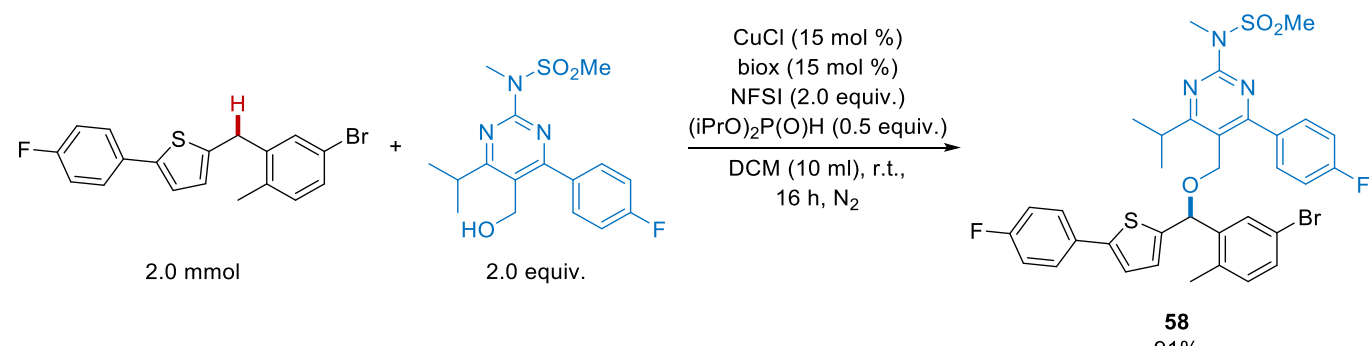

Copper(I) chloride (15 mg, $0.30 \mathrm{mmol}), 4,4$ ',5,5'-tetrahydro-2,2'-bioxazole (42 mg, $0.30 \mathrm{mmol}$ ), NFSI (1261 $\mathrm{mg}, \quad 4.0 \mathrm{mmol}), \quad$ 4-(4-Fluorophenyl)-6-isopropyl-2-[(N-methyl-Nmethylsufonyl)amino]pyrimidine-5-yl-methanol (1414 mg, $4.0 \mathrm{mmol}$ ) and 2-(5-Bromo-2methylbenzyl)-5-(4-fluorophenyl]thiophene $(723 \mathrm{mg}, 2.0 \mathrm{mmol})$ were added under air to a $24 \mathrm{ml}$ vial containing a magnetic stir bar. Then the vial was capped with a pierceable Teflon cap. A needle was pierced through the cap and kept in the cap facilitate the exchange of the vial headspace with the atmosphere. Then the vial was transferred to a glove box, through three vacuum-nitrogenbackfill cycles. The needle was then removed in the glove box. Dichloromethane $(10 \mathrm{~mL})$ and diisopropyl phosphite $(163 \mu \mathrm{L}, 1.0 \mathrm{mmol})$ were added into the vial. The vial was capped, taken out of the glove box and stirred at room temperature for $16 \mathrm{~h}$. When the reaction finished, triethylamine $(1.4 \mathrm{~mL}, 10 \mathrm{mmol})$ was added. Then the mixture was evaporated under vacuum and the crude mixture was purified by flash chromatography (silica gel, eluted by pentane/ethyl acetate $=9: 1) .1 .30 \mathrm{~g}(91 \%)$ of pale-yellow liquid was obtained.

\section{Procedure for the preparation of the substrate 59.}

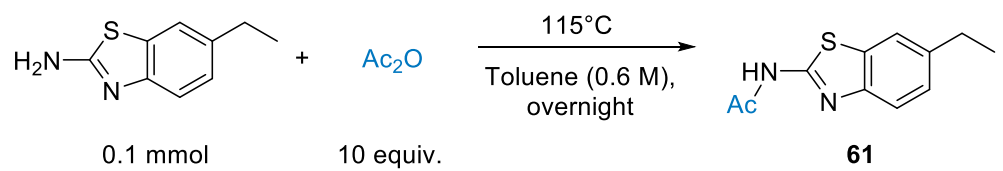

The synthetic protocol for the preparation of $\mathbf{5 9}$ was adapted from a literature procedure ${ }^{2}$. 6-ethyl1,3-benzothiazol-2-amine (446 mg, $2.5 \mathrm{mmol}$ ) was weighed into $15 \mathrm{ml}$ glass vial containing a 
Teflon magnetic stir bar. Toluene $(15 \mathrm{ml})$ and acetic anhydride $(94.5 \mu \mathrm{L}, 10.0$ equiv.) were added into the flask in sequence. The vial was then capped with a Teflon pierceable cap and the reaction mixture was stirred at $115{ }^{\circ} \mathrm{C}$ overnight. The reaction was concentrated under vacuum and the residue was triturated with $5 \mathrm{ml}$ ethyl acetate and $50 \mathrm{ml}$ pentane. The product was filtered out and dried. Trituration and filtration were repeated three times and $473 \mathrm{mg}$ (86\% isolated yield) of 59 (the substrate of 27) was collected.

\section{Procedure for the preparation of the substrate 60.}

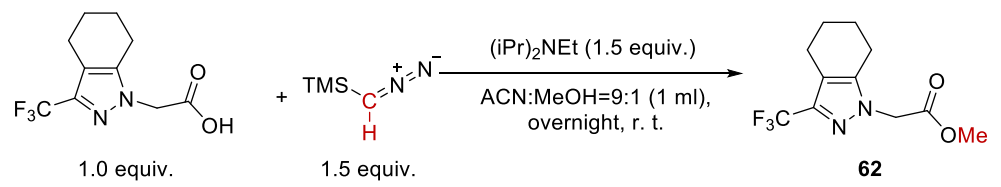

The synthetic protocol for the preparation of $\mathbf{6 2}$ was adapted from a literature procedure ${ }^{3} .2-[3$ (trifluoromethyl)-4,5,6,7-tetrahydro-1H-indazol-1-yl]acetic acid (298 mg, $1.2 \mathrm{mmol}$ ) was weighed into $15 \mathrm{ml}$ vial containing a Teflon magnetic stir bar. A mixture of acetonitrile and $\mathrm{MeOH}(9: 1,4.8$ $\mathrm{ml})$, followed diisopropylethylamine $(0.43 \mathrm{ml}, 1.5$ equiv. $)$ were added into the flask and the mixture was stirred for $10 \mathrm{~min}$, and then trimethylsilyldizaomethane (2.0 M Hexane solution, 0.9 $\mathrm{ml}, 1.5$ equiv.) was added dropwise into the reaction mixture. When no obvious bubbling was observed, the vial was capped with a pierceable Teflon cap and the reaction mixture was stirred at room temperature overnight. The reaction mixture was concentrated under vacuum and the residue was purified by column chromatography (pentane:ethyl acetate $=4: 1) .255 \mathrm{mg}$ white solid $(82 \%$ isolated yield) of $\mathbf{6 0}$ (the substrate of $\mathbf{2 8}$ ) was collected.

\section{Procedure for the preparation of the substrate 61.}
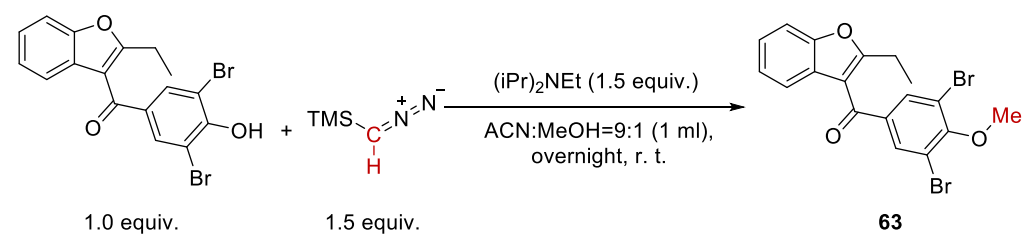

63

The synthetic protocol for the preparation of $\mathbf{6 1}$ was adapted from a literature procedure ${ }^{3}$. Benzbromarone $(1.70 \mathrm{~g}, 4.0 \mathrm{mmol})$ was weighed into a $50 \mathrm{ml}$ round bottom flask containing a Teflon magnetic stir bar. A mixture of acetonitrile and $\mathrm{MeOH}(9: 1,16 \mathrm{ml})$, followed diisopropylethylamine ( $1.44 \mathrm{ml}, 1.5$ equiv.) was added into the flask and the mixture was stirred for $10 \mathrm{~min}$, and then trimethylsilyldizaomethane (2.0 M Hexane solution, $3 \mathrm{ml}, 1.5$ equiv.) was added dropwise into the reaction mixture. A funnel was placed upside down on top of the flask to minimize the evaporation of the solvent and the reaction mixture was stirred at room temperature overnight. The reaction mixture was concentrated under vacuum and the residue was purified by purified by column chromatography (pentane:ethyl acetate $=4: 1) .1 .67 \mathrm{~g}(95 \%$ isolated yield) of 61 (the substrate of 34) was collected. 


\section{Optimization of the Reaction Conditions}

\section{Table S1a. Ligand Optimization}

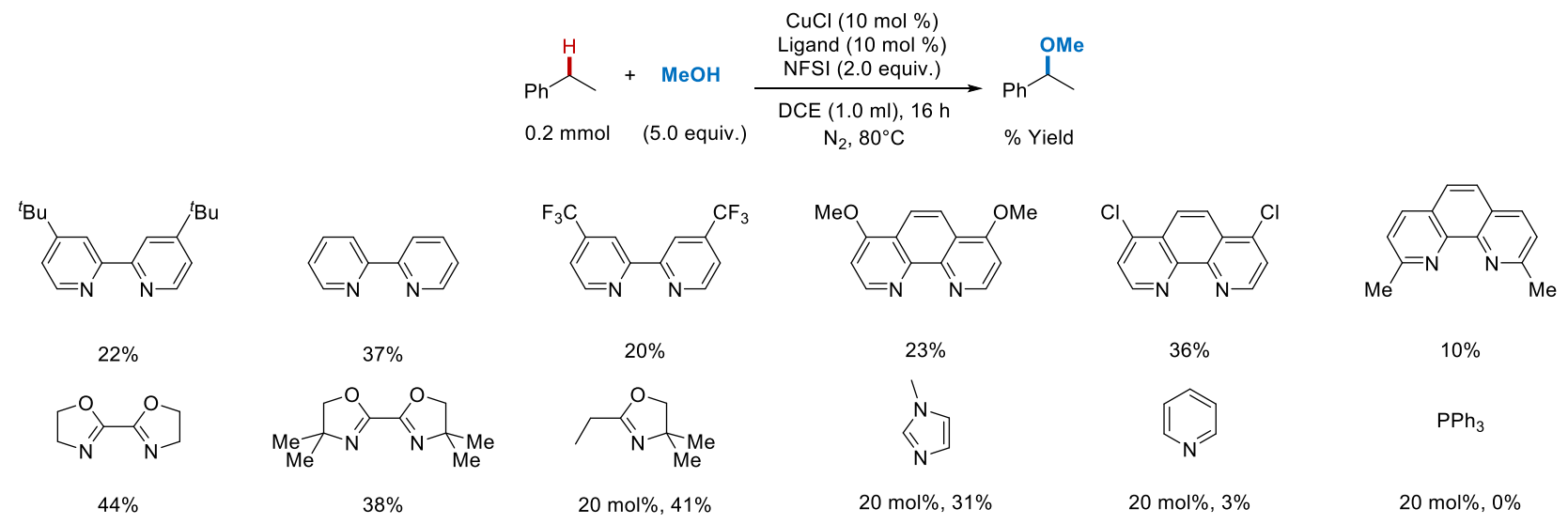

Table S2b. Unsuccessful Ligand Testing for Enantioselective Methoxylation

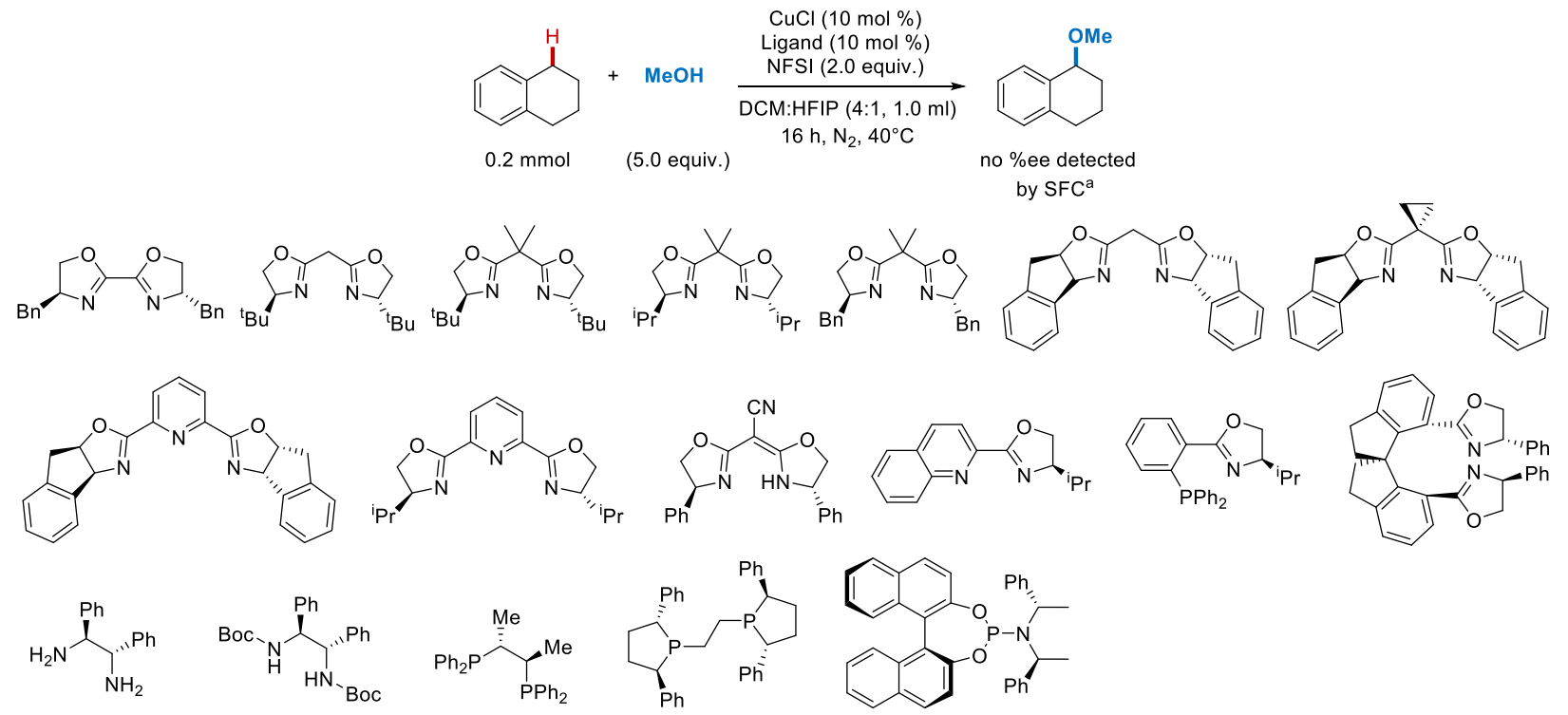

${ }^{a}$ SFC, supercriticial fluid chromatography 
Table S2. Optimization of the Reaction Conditions with Various Solvents, Cu Salts and Temperature

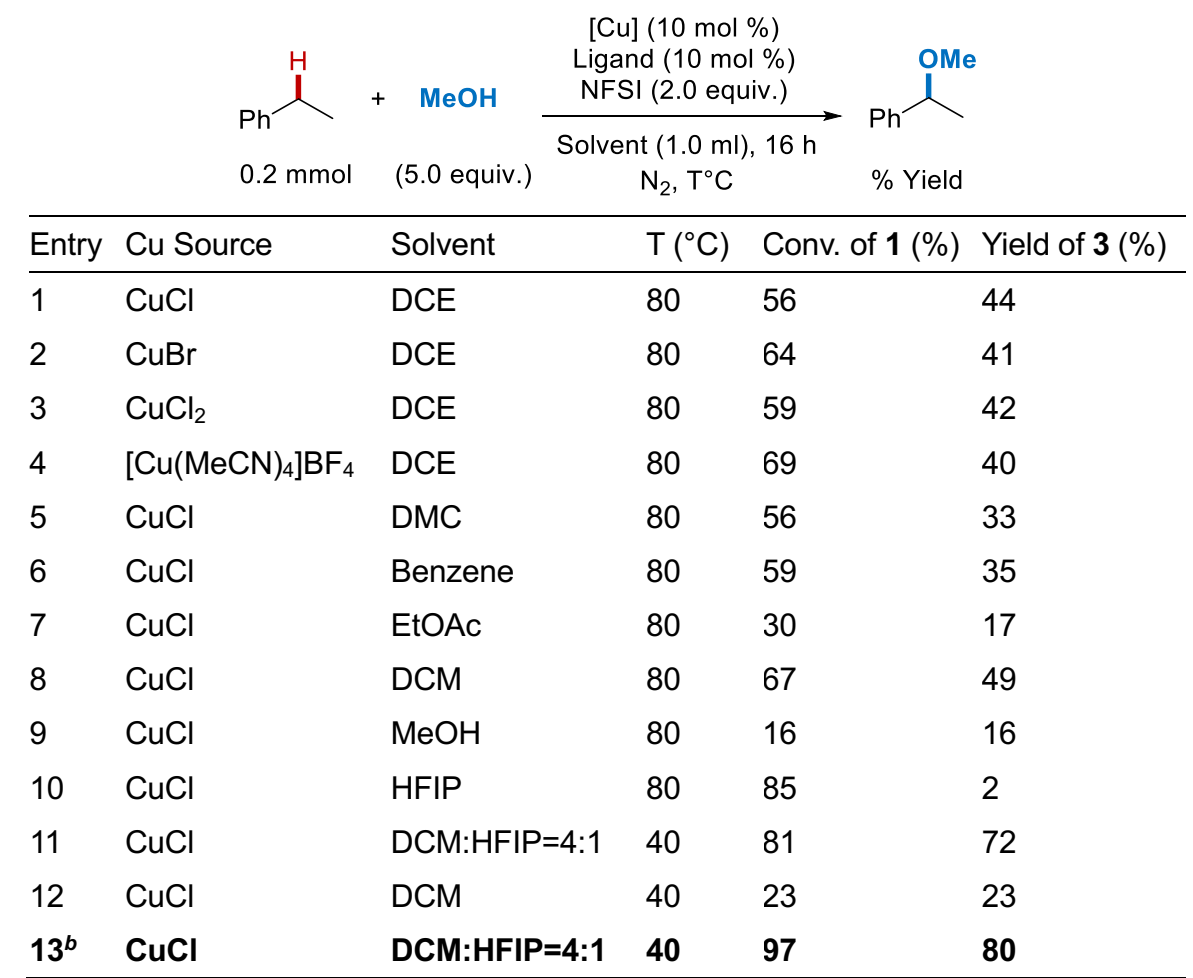

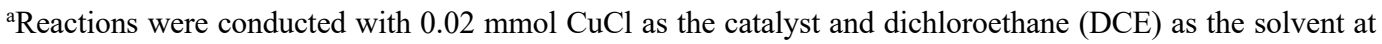
$80^{\circ} \mathrm{C}$. ${ }^{b} 50 \mathrm{~mol} \%$ of $(\mathrm{MeO})_{2} \mathrm{P}(\mathrm{O}) \mathrm{H}$ was added. DCE, 1,2-dichloroethane; DMC, dimethyl carbonate; DCM, dichloromethane; HFIP, hexafluoroisopropanol; T, temperature; Conv., conversion. 
Table S3. Investigation of dimethylphosphite with 4-phenylethylbenzene as the substrate

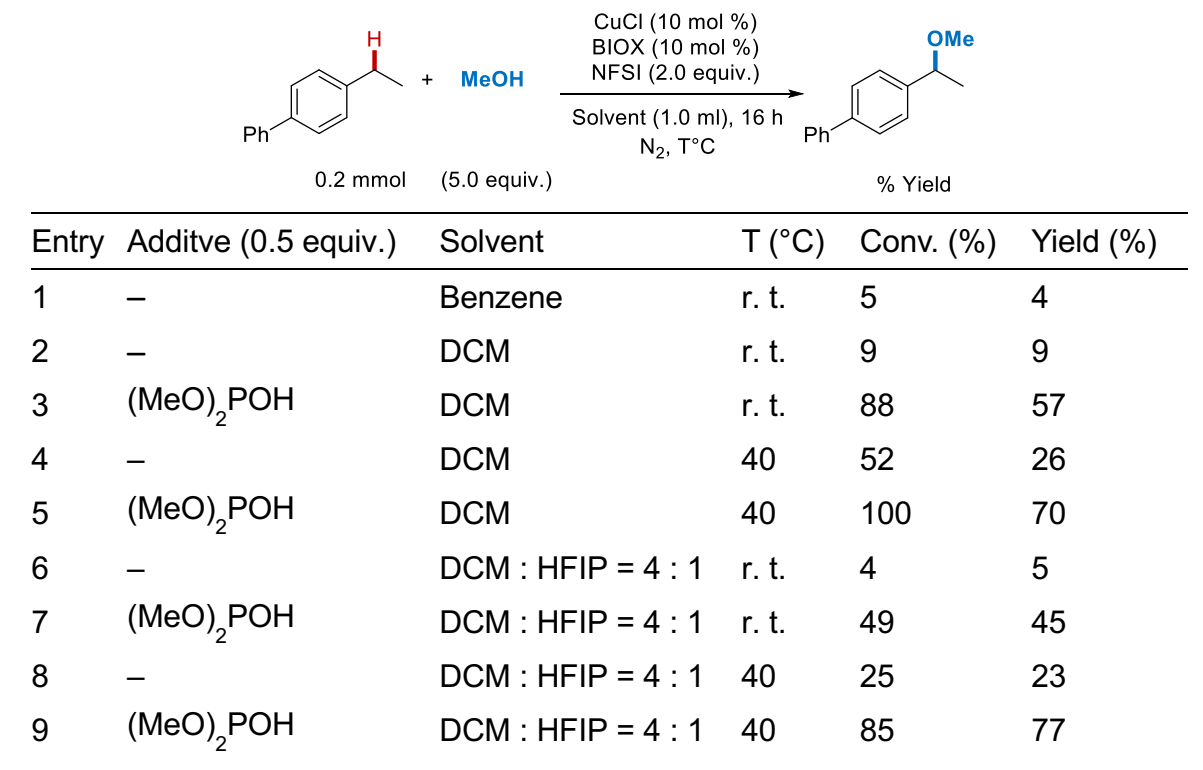

Table S4. Investigation of various reductants with ethylbenzene as the substrate

\begin{tabular}{|c|c|c|c|}
\hline \multirow{2}{*}{\multicolumn{2}{|c|}{$\underset{0.2 \mathrm{mmol}}{\stackrel{H}{H}}+\underset{\mathrm{MeOH}}{(5.0 \text { equiv. })}$}} & \multirow{2}{*}{$\begin{array}{c}\text { CuCl (10 mol \%) } \\
\text { biox }(10 \mathrm{~mol} \%) \\
\text { NFSI }(2.0 \text { equiv.) } \\
\text { Reductant }(0.5 \text { equiv. }) \\
\text { DCM:HFIP }=4: 1(1.0 \mathrm{ml})\end{array}$} & \multirow{2}{*}{$\%$ Yield } \\
\hline & & & \\
\hline Entry & Reductant & Conv. of $1(\%)$ & Yield of $\mathbf{3}(\%)$ \\
\hline 1 & $(\mathrm{MeO})_{2} \mathrm{P}(\mathrm{O}) \mathrm{H}$ & 100 & 80 \\
\hline 2 & $(\mathrm{EtO})_{2} \mathrm{P}(\mathrm{O}) \mathrm{H}$ & 91 & 77 \\
\hline 3 & $(\mathrm{PrO})_{2} \mathrm{P}(\mathrm{O}) \mathrm{H}$ & 88 & 73 \\
\hline 4 & $\left({ }^{t} \mathrm{BuO}\right){ }_{2} \mathrm{P}(\mathrm{O}) \mathrm{H}$ & 34 & 28 \\
\hline 5 & $\left({ }^{n} \mathrm{BuO}\right)_{2} \mathrm{P}(\mathrm{O}) \mathrm{H}$ & 94 & 75 \\
\hline 6 & $(\mathrm{MeO})_{2} \mathrm{MeSiH}$ & 79 & 70 \\
\hline 7 & $(\mathrm{EtO})_{2} \mathrm{MeSiH}$ & 100 & 62 \\
\hline 8 & PhNHNHPh & 7 & 0 \\
\hline 9 & $\mathrm{EtCO}_{2} \mathrm{NHNHCO}_{2} \mathrm{Et}$ & 94 & 62 \\
\hline 10 & $\mathrm{P}\left({ }^{n} \mathrm{Bu}\right)_{3}$ & 37 & 22 \\
\hline 11 & Sodium Ascorbate & 100 & 62 \\
\hline
\end{tabular}




\section{Unsuccessful Substrates.}

Not all substrates tested were effective in the benzylic etherification reaction. The substrates in Table S5a afford methyl ethers in $<40 \%$ yield, based on analysis of the crude reaction mixture by ${ }^{1}$ H NMR spectroscopy (Table S5a). An elimination product was observed in the case of splitomicin. Substrates in Table S5b generally underwent high conversion but led to low-to-negligible yields of the desired products. Pyridines, quinoline and pyrimidine derivatives have been reported to react directly with NFSI and no desirable methoxylated product was observed under all the reaction conditions tested ${ }^{4}$. Substrates in Table S5c are rather inactive, giving low conversions and low yields. Substrates with free phenols or acidic N-H groups suffered from low conversion, possibly reflecting inhibition by coordination to $\mathrm{Cu}$. Sites adjacent to electron-deficient heterocycles were generally unreactive, and unreacted starting material was observed with the substrates in Table S5c.

Table S5. Unsuccessful substrates in benzylic C-H methoxylation

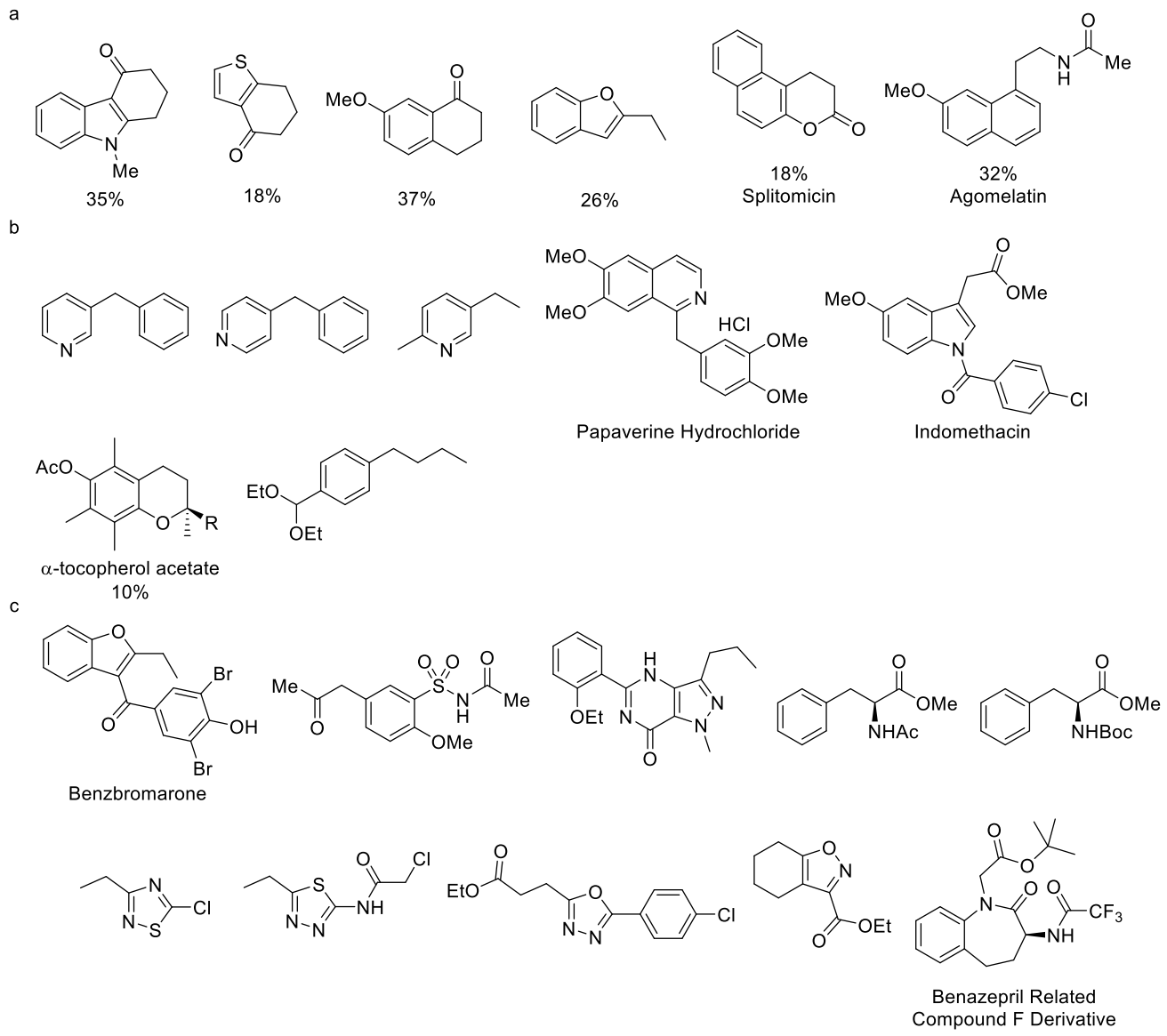


Table S6. Investigation of various phosphites with a canagliflozin precursor

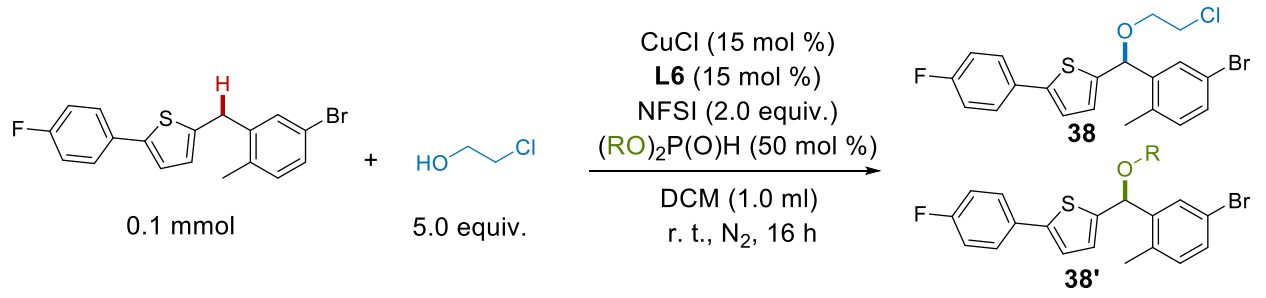

\begin{tabular}{llccc}
\hline Entry & Additive & Conv. of the substrate (\%) & ${\text { Yield of 38' }(\%)^{\mathrm{a}}}^{\mathrm{a}}$ & Yield of 38 (\%) $^{\mathrm{a}}$ \\
\hline 1 & $(\mathrm{MeO})_{2} \mathrm{P}(\mathrm{O}) \mathrm{H}$ & 83 & 18 & 64 \\
2 & $(\mathrm{EtO})_{2} \mathrm{P}(\mathrm{O}) \mathrm{H}$ & 92 & 8 & 81 \\
3 & $\left({ }^{(} \mathrm{Pr}\right)_{2} \mathrm{P}(\mathrm{O}) \mathrm{H}$ & 95 & 2 & 92 \\
4 & $\left({ }^{(} \mathrm{Bu}\right)_{2} \mathrm{P}(\mathrm{O}) \mathrm{H}$ & 94 & 8 & 84 \\
5 & $(\mathrm{Bn})_{2} \mathrm{P}(\mathrm{O}) \mathrm{H}$ & 92 & 13 & 76 \\
6 & $\left(\mathrm{CF}_{3} \mathrm{CH}_{2} \mathrm{O}\right)_{2} \mathrm{P}(\mathrm{O}) \mathrm{H}$ & 69 & 3 & 59 \\
7 & $\left({ }^{(} \mathrm{Bu}\right)_{2} \mathrm{P}(\mathrm{O}) \mathrm{H}$ & 68 & 3 & 65 \\
8 & - & 23 & - & 23 \\
\hline
\end{tabular}

${ }^{a}$ Calibrated ${ }^{1} \mathrm{H}$ NMR yields using dibromomethane as the internal standard. Conv., conversion. 


\section{Characterization of Compounds}<smiles>COC(C)c1ccc(-c2ccccc2)cc1</smiles>

4-(1-methoxyethyl)-1,1'-biphenyl, 4. Characterization data matched those previously reported ${ }^{5}$.

Reaction run at $0.4 \mathrm{mmol}$ scale and $73.8 \mathrm{mg}(87 \%)$ of colorless liquid isolated.

${ }^{1} \mathrm{H} \mathrm{NMR}\left(\mathrm{CDCl}_{3}, 400 \mathrm{MHz}\right): 7.62-7.55(\mathrm{~m}, 4 \mathrm{H}), 7.44(\mathrm{t}, J=7.5 \mathrm{~Hz}, 2 \mathrm{H}), 7.38(\mathrm{~d}, J=8.0 \mathrm{~Hz}, 2 \mathrm{H}), 7.34$ (t, $J=7.4 \mathrm{~Hz}, 1 \mathrm{H}), 4.35(\mathrm{q}, J=6.5 \mathrm{~Hz}, 1 \mathrm{H}), 3.26(\mathrm{~s}, 3 \mathrm{H}), 1.48(\mathrm{~d}, J=6.4 \mathrm{~Hz}, 3 \mathrm{H}) \mathrm{ppm}$.

${ }^{13} \mathrm{C} \mathrm{NMR}\left(\mathrm{CDCl}_{3}, 100 \mathrm{MHz}\right)$ : 142.6, 141.0, 140.4, 128.8, 127.2 (2C), 127.1, 126.6, 79.4, 56.5, 23.9 ppm.<smiles>COc1ccc(C(C)OC)cc1</smiles>

1-methoxy-4-(1-methoxyethyl)benzene, 6. Characterization data matched those previously reported ${ }^{6}$.

Reaction run at $0.4 \mathrm{mmol}$ scale and $45.9 \mathrm{mg}(69 \%)$ of colorless liquid isolated.

${ }^{1} \mathrm{H} \mathrm{NMR}\left(\mathrm{CDCl}_{3}, 400 \mathrm{MHz}\right): 7.23$ (d, $\left.J=8.5 \mathrm{~Hz}, 1 \mathrm{H}\right), 6.89$ (d, $\left.J=8.6 \mathrm{~Hz}, 1 \mathrm{H}\right), 4.25$ (q, $\left.J=6.4 \mathrm{~Hz}, 1 \mathrm{H}\right)$, $3.80(\mathrm{~s}, 3 \mathrm{H}), 3.19$ (s, 3H), $1.42(\mathrm{~d}, J=6.4 \mathrm{~Hz}, 3 \mathrm{H}) \mathrm{ppm}$.

${ }^{13} \mathrm{C} \mathrm{NMR}\left(\mathrm{CDCl}_{3}, 100 \mathrm{MHz}\right): 159.0,135.5,127.4,113.8,79.1,56.2,55.3,23.8 \mathrm{ppm}$.<smiles>COC(C)c1ccc(Br)cc1</smiles>

1-bromo-4-(1-methoxyethyl)benzene, 7. Characterization data matched those previously reported 5 .

Reaction run at $0.2 \mathrm{mmol}$ scale and $28.4 \mathrm{mg}(66 \%)$ of colorless liquid isolated.

${ }^{1} \mathrm{H} \mathrm{NMR}\left(\mathrm{CDCl}_{3}, 400 \mathrm{MHz}\right): 7.47$ (d, $\left.J=8.4 \mathrm{~Hz}, 2 \mathrm{H}\right), 7.19$ (d, $\left.J=8.5 \mathrm{~Hz}, 2 \mathrm{H}\right), 4.26$ (q, $\left.J=6.5 \mathrm{~Hz}, 1 \mathrm{H}\right)$, $3.21(\mathrm{~s}, 3 \mathrm{H}), 1.40(\mathrm{t}, J=6.5 \mathrm{~Hz}, 3 \mathrm{H}) \mathrm{ppm}$.

${ }^{13} \mathrm{C} \mathrm{NMR}\left(\mathrm{CDCl}_{3}, 100 \mathrm{MHz}\right): 142.6,131.6,127.9,121.2,79.0,56.5,23.8 \mathrm{ppm}$.<smiles>COC(C)c1ccc(OC(C)=O)cc1</smiles>

4-(1-methoxyethyl)phenyl acetate, 8 .

Reaction run at $0.4 \mathrm{mmol}$ scale and $46.6 \mathrm{mg}(60 \%)$ of colorless liquid isolated.

${ }^{1} \mathrm{H} \mathrm{NMR}\left(\mathrm{CDCl}_{3}, 400 \mathrm{MHz}\right): 7.31$ (d, $\left.J=8.4 \mathrm{~Hz}, 2 \mathrm{H}\right), 7.06$ (d, $\left.J=8.5 \mathrm{~Hz}, 2 \mathrm{H}\right), 4.29$ (q, $\left.J=6.5 \mathrm{~Hz}, 1 \mathrm{H}\right)$, $3.22(\mathrm{~s}, 3 \mathrm{H}), 2.30(\mathrm{~s}, 3 \mathrm{H}), 1.42(\mathrm{~d}, J=6.4 \mathrm{~Hz}, 3 \mathrm{H}) \mathrm{ppm}$. 
${ }^{13} \mathrm{C} \mathrm{NMR}\left(\mathrm{CDCl}_{3}, 100 \mathrm{MHz}\right):$ 169.5, 149.9, 141.1, 127.2, 121.5, 79.1, 56.5, 23.9, $21.2 \mathrm{ppm}$.

HRMS Calculated for $\left[\mathrm{C}_{11} \mathrm{H}_{14} \mathrm{O}_{3}+\mathrm{NH}_{4}\right]^{+}: 212.1281$, Found: 212.1278.<smiles>CCCCCC(OC)c1ccccc1</smiles>

(1-methoxyhexyl)benzene, $\mathbf{1 0}$.

Reaction run at $0.4 \mathrm{mmol}$ scale and $53.8 \mathrm{mg}(70 \%)$ of colorless liquid isolated.

${ }^{1} \mathrm{H} \mathrm{NMR}\left(\mathrm{CDCl}_{3}, 400 \mathrm{MHz}\right): 7.38-7.31(\mathrm{~m}, 2 \mathrm{H}), 7.31-7.24(\mathrm{~m}, 3 \mathrm{H}), 4.07(\mathrm{dd}, J=7.3,6.0 \mathrm{~Hz}, 1 \mathrm{H}), 3.20$

$(\mathrm{s}, 3 \mathrm{H}), 1.86-1.72(\mathrm{~m}, 1 \mathrm{H}), 1.67-1.55(\mathrm{~m}, 1 \mathrm{H}), 1.46-1.33(\mathrm{~m}, 1 \mathrm{H}), 1.32-1.16(\mathrm{~m}, 5 \mathrm{H}), 0.86(\mathrm{t}, J=6.9$

$\mathrm{Hz}, 3 \mathrm{H}) \mathrm{ppm}$.

${ }^{13} \mathrm{C}$ NMR $\left(\mathrm{CDCl}_{3}, 100 \mathrm{MHz}\right)$ : 142.6, 128.3, 127.4, 126.7, 84.2, 56.6, 38.2, 31.8, 25.5, 22.6, $14.1 \mathrm{ppm}$.

HRMS (ASAP-MS) Calculated for $\left[\mathrm{C}_{13} \mathrm{H}_{20} \mathrm{O}-\mathrm{OMe}\right]^{+}: 161.1325$, Found: 161.1323.<smiles>COC(CCCl)c1ccccc1</smiles>

(3-chloro-1-methoxypropyl)benzene, 11.

Reaction run at $0.4 \mathrm{mmol}$ scale and $37.7 \mathrm{mg}(51 \%)$ of colorless liquid isolated. Characterization data matched those previously reported ${ }^{7}$.

${ }^{1} \mathrm{H}$ NMR $\left(\mathrm{CDCl}_{3}, 400 \mathrm{MHz}\right): 7.40$ - $7.34(\mathrm{~m}, 2 \mathrm{H}), 7.33-7.27$ (m, 3H), 4.37 (dd, $\left.J=8.5,4.8,1 \mathrm{H}\right), 3.71$

(ddd, $J=10.8,8.1,5.6,1 \mathrm{H}), 3.50(\mathrm{ddd}, J=10.8,5.9,1 \mathrm{H}), 3.23(\mathrm{~s}, 3 \mathrm{H}), 2.23$ (ddt, $J=14.2,8.4,5.7 \mathrm{~Hz}$, 1H), 2.01 (dddd, $J=14.3,8.1,6.0,4.9 \mathrm{~Hz}, 1 \mathrm{H}$ ) ppm.

${ }^{13} \mathrm{C} \mathrm{NMR}\left(\mathrm{CDCl}_{3}, 100 \mathrm{MHz}\right): 141.2,128.6,127.9,126.6,80.4,56.8,41.7,40.9 \mathrm{ppm}$.<smiles>COC(CCBr)c1ccccc1</smiles>

(3-bromo-1-methoxypropyl)benzene, 12. Characterization data matched those previously reported ${ }^{8}$. Reaction run at $0.4 \mathrm{mmol}$ scale and $37.7 \mathrm{mg}(41 \%)$ of colorless liquid isolated.

${ }^{1} \mathrm{H}$ NMR ( $\left.\mathrm{CDCl}_{3}, 400 \mathrm{MHz}\right): 7.40$ - $7.34(\mathrm{~m}, 2 \mathrm{H}), 7.33-7.27(\mathrm{~m}, 3 \mathrm{H}), 4.35$ (dd, $\left.J=8.4,4.8 \mathrm{~Hz}, 1 \mathrm{H}\right), 3.61$ $-3.52(\mathrm{~m}, 1 \mathrm{H}), 3.41-3.33(\mathrm{~m}, 1 \mathrm{H}), 3.24(\mathrm{~s}, 3 \mathrm{H}), 2.36-2.26(\mathrm{~m}, 1 \mathrm{H}), 2.15-2.04(\mathrm{~m}, 1 \mathrm{H}) \mathrm{ppm}$.

${ }^{13} \mathrm{C} \mathrm{NMR}\left(\mathrm{CDCl}_{3}, 100 \mathrm{MHz}\right): 141.1,128.6,127.9,126.6,81.4,56.9,41.1,30.3 \mathrm{ppm}$. 
<smiles>COC(=O)C(OC)c1ccc(OC)cc1</smiles>

methyl 2-methoxy-2-(4-methoxyphenyl)acetate, 13. Characterization data matched those previously reported 9 .

Reaction run at $0.4 \mathrm{mmol}$ scale and $74.8 \mathrm{mg}(89 \%)$ of colorless liquid isolated.

${ }^{1} \mathrm{H}$ NMR $\left(\mathrm{CDCl}_{3}, 400 \mathrm{MHz}\right): 7.36(\mathrm{~d} J=8.6 \mathrm{~Hz}, 2 \mathrm{H}), 6.90$ (d, $\left.J=8.8 \mathrm{~Hz}, 2 \mathrm{H}\right), 4.72(\mathrm{~s}, 1 \mathrm{H}), 3.80(\mathrm{~s}, 3 \mathrm{H})$, $3.72(\mathrm{~s}, 3 \mathrm{H}), 3.38(\mathrm{~s}, 3 \mathrm{H}) \mathrm{ppm}$.

${ }^{13} \mathrm{C} \mathrm{NMR}\left(\mathrm{CDCl}_{3}, 100 \mathrm{MHz}\right): 171.4,160.0,128.6,128.2,114.1,82.1,57.1,55.3,52.3 \mathrm{ppm}$.<smiles>COC1CCCc2ccccc21</smiles>

1-methoxy-1,2,3,4-tetrahydronaphthalene, 14. Characterization data matched those previously reported ${ }^{10}$. Reaction run at $0.4 \mathrm{mmol}$ scale and $38.9 \mathrm{mg}(60 \%)$ of colorless liquid isolated.

${ }^{1} \mathrm{H}$ NMR $\left(\mathrm{CDCl}_{3}, 400 \mathrm{MHz}\right): 7.38$ - $7.31(\mathrm{~m}, 1 \mathrm{H}), 7.22-7.14(\mathrm{~m}, 1 \mathrm{H}), 7.12-7.06(\mathrm{~m}, 1 \mathrm{H}), 4.31(\mathrm{t}, J=$ $4.7 \mathrm{~Hz}, 1 \mathrm{H}), 2.83(\mathrm{dt}, J=16.8,5.7 \mathrm{~Hz}, 1 \mathrm{H}), 2.71(\mathrm{ddd}, J=16.7,8.3,6.0 \mathrm{~Hz}, 1 \mathrm{H}), 2.07-1.93(\mathrm{~m}, 2 \mathrm{H}), 1.93$ $-1.83(\mathrm{~m}, 1 \mathrm{H}), 1.79-1.67$ (m, 1H) ppm.

${ }^{13} \mathrm{C} \mathrm{NMR}\left(\mathrm{CDCl}_{3}, 100 \mathrm{MHz}\right): 137.5,136.6,129.3,129.0,127.5,125.7,76.8,56.2,29.1,27.4,18.7 \mathrm{ppm}$.<smiles>COC(c1ccccc1)c1ccccc1</smiles>

(methoxymethylene)dibenzene, 15. Characterization data matched those previously reported ${ }^{11}$. Reaction run at $0.4 \mathrm{mmol}$ scale and $63.4 \mathrm{mg}(80 \%)$ of colorless liquid isolated. ${ }^{1} \mathrm{H} \mathrm{NMR}\left(\mathrm{CDCl}_{3}, 400 \mathrm{MHz}\right)$ : 7.37-7.28 (m, 8H), 7.26 - $7.21(\mathrm{~m}, 2 \mathrm{H}), 5.24$ (s, 1H), 3.38 (s, 3H) ppm. ${ }^{13} \mathrm{C} \mathrm{NMR}\left(\mathrm{CDCl}_{3}, 100 \mathrm{MHz}\right): 142.1,128.4,127.5,126.9,85.5,57.1 \mathrm{ppm}$.<smiles>COC(c1ccc(F)cc1)c1ccc(F)cc1</smiles>

4,4'-(methoxymethylene)bis(fluorobenzene), 16. Characterization data matched those previously reported ${ }^{12}$. Reaction run at $0.4 \mathrm{mmol}$ scale and $71.2 \mathrm{mg}(76 \%)$ of colorless liquid isolated.

${ }^{1} \mathrm{H}$ NMR ( $\left.\mathrm{CDCl}_{3}, 400 \mathrm{MHz}\right): 7.31$ - 7.24 (m, 4H), 7.05 - 6.97 (m, 4H), 5.20 (s, 1H), 3.35 (s, 3H) ppm. ${ }^{13} \mathrm{C} \mathrm{NMR}\left(\mathrm{CDCl}_{3}, 100 \mathrm{MHz}\right): 162.2(\mathrm{~d}, J=244.3 \mathrm{~Hz}), 137.7$ (d, $\left.J=3.2 \mathrm{~Hz}\right), 128.5$ (d, $\left.J=8.1 \mathrm{~Hz}\right), 115.3$ $(\mathrm{d}, J=21.3 \mathrm{~Hz}), 84.0,56.9 \mathrm{ppm}$. 
${ }^{19} \mathrm{~F}$ NMR (377 MHz, $\mathrm{CDCl}_{3}$ ): -114.9 ppm.<smiles>COC(c1ccccc1)c1ccc(Br)cc1</smiles>

1-bromo-4-(methoxy(phenyl)methyl)benzene, 17. Characterization data matched those previously reported $^{13}$.

Reaction run at $0.4 \mathrm{mmol}$ scale and $84.3 \mathrm{mg}(76 \%)$ of colorless liquid isolated.

${ }^{1} \mathrm{H}$ NMR $\left(\mathrm{CDCl}_{3}, 400 \mathrm{MHz}\right): 7.44(\mathrm{~d} J=8.4 \mathrm{~Hz}, 2 \mathrm{H}), 7.35-7.24(\mathrm{~m}, 5 \mathrm{H}), 7.22(\mathrm{dd}, J=8.6,0.6 \mathrm{~Hz}, 2 \mathrm{H})$, $5.19(\mathrm{~s}, 1 \mathrm{H}), 3.36(\mathrm{~s}, 3 \mathrm{H}) \mathrm{ppm}$.

${ }^{13} \mathrm{C} \mathrm{NMR}\left(\mathrm{CDCl}_{3}, 100 \mathrm{MHz}\right): 141.5,141.3,131.5,128.6,128.6,127.8,126.9,121.4,84.7,57.0 \mathrm{ppm}$.<smiles>COC(c1ccccc1)c1ccccc1Br</smiles>

1-bromo-2-(methoxy(phenyl)methyl)benzene, 18. Characterization data matched those previously reported ${ }^{14}$.

Reaction run at $0.4 \mathrm{mmol}$ scale and $59.9 \mathrm{mg}$ (54\%) of colorless liquid isolated.

${ }^{1} \mathrm{H}$ NMR $\left(\mathrm{CDCl}_{3}, 400 \mathrm{MHz}\right): 7.56$ - $7.50(\mathrm{~m}, 2 \mathrm{H}), 7.42$ - 7.37 (m, 2H), 7.35 - $7.29(\mathrm{~m}, 3 \mathrm{H}), 7.28$ - 7.22 $(\mathrm{m}, 1 \mathrm{H}), 7.12(\mathrm{td}, J=7.6,1.7 \mathrm{~Hz}, 1 \mathrm{H}), 5.67(\mathrm{~s}, 1 \mathrm{H}), 3.39$ (s, 3H) ppm.

${ }^{13} \mathrm{C} \mathrm{NMR}\left(\mathrm{CDCl}_{3}, 100 \mathrm{MHz}\right): 141.0,140.5,132.8,129.0,128.5,128.4,127.8,127.7,127.4,123.6,83.5$, $57.2 \mathrm{ppm}$.<smiles>CCOc1ccc(C(OC)c2cc(Br)ccc2Cl)cc1</smiles>

4-bromo-1-chloro-2-((4-ethoxyphenyl)(methoxy)methyl)benzene, 19.

Reaction run at $0.2 \mathrm{mmol}$ scale and $112 \mathrm{mg}(79 \%)$ of colorless liquid isolated.

${ }^{1} \mathrm{H}$ NMR $\left(\mathrm{CDCl}_{3}, 400 \mathrm{MHz}\right): 7.75(\mathrm{~d}, J=2.4 \mathrm{~Hz}, 1 \mathrm{H}), 7.31(\mathrm{dd}, J=8.5,2.5 \mathrm{~Hz}, 1 \mathrm{H}), 7.25(\mathrm{~d}, J=8.7 \mathrm{~Hz}$, 2H), $7.18(\mathrm{~d}, J=8.5 \mathrm{~Hz}, 1 \mathrm{H}), 6.85(\mathrm{~d}, J=8.7 \mathrm{~Hz}, 2 \mathrm{H}), 5.52(\mathrm{~s}, 1 \mathrm{H}), 4.01(\mathrm{q}, J=7.0 \mathrm{~Hz}, 2 \mathrm{H}), 3.36(\mathrm{~s}, 3 \mathrm{H})$, $1.39(\mathrm{t}, J=7.0 \mathrm{~Hz}, 3 \mathrm{H}) \mathrm{ppm}$.

${ }^{13} \mathrm{C} \mathrm{NMR}\left(\mathrm{CDCl}_{3}, 100 \mathrm{MHz}\right): 158.7,142.0,131.7,131.5,131.5,130.9,130.6,128.8,121.0,114.4,80.8$, 63.4, 57.0, $14.8 \mathrm{ppm}$.

HRMS (ASAP-MS) Calculated for $\left[\mathrm{C}_{16} \mathrm{H}_{16} \mathrm{BrClO}_{2}-\mathrm{OMe}\right]^{+}: 322.9833$, Found: 322.9832. 
<smiles>CCCCCC(OC)c1ccc(Br)s1</smiles>

2-bromo-5-(1-methoxyhexyl)thiophene, 20.

Reaction run at $0.4 \mathrm{mmol}$ scale and $72.1 \mathrm{mg}(65 \%)$ of colorless liquid isolated.

${ }^{1} \mathrm{H}$ NMR $\left(\mathrm{CDCl}_{3}, 400 \mathrm{MHz}\right): 6.90(\mathrm{~d}, J=3.7 \mathrm{~Hz}, 1 \mathrm{H}), 6.70(\mathrm{~d}, J=3.7 \mathrm{~Hz}, 1 \mathrm{H}), 4.25(\mathrm{t}, J=6.8 \mathrm{~Hz}, 1 \mathrm{H})$, $3.26(\mathrm{~s}, 3 \mathrm{H}), 1.91-1.78(\mathrm{~m}, 1 \mathrm{H}), 1.67(\mathrm{~m}, 1 \mathrm{H}), 1.46-1.17(\mathrm{~m}, 6 \mathrm{H}), 0.87$ (t, $J=6.9 \mathrm{~Hz}, 3 \mathrm{H}) \mathrm{ppm}$.

${ }^{13} \mathrm{C} \mathrm{NMR}\left(\mathrm{CDCl}_{3}, 100 \mathrm{MHz}\right)$ : 148.3, 129.0, 125.6, 111.6, 79.8, 56.5, 38.1, 31.6, 25.4, 22.5, $14.0 \mathrm{ppm}$.

HRMS Calculated for $\left[\mathrm{C}_{11} \mathrm{H}_{17} \mathrm{BrOS}+\mathrm{Na}\right]^{+}: 299.0076$, Found: 299.0074 .<smiles>CCCCCC(OC)c1cccs1</smiles>

2-(1-methoxyhexyl)thiophene, 21.

Reaction run at $0.4 \mathrm{mmol}$ scale and $40.5 \mathrm{mg}(51 \%)$ of colorless liquid isolated.

${ }^{1} \mathrm{H}$ NMR $\left(\mathrm{CDCl}_{3}, 400 \mathrm{MHz}\right): 7.30$ - $7.23(\mathrm{~m}, 1 \mathrm{H}), 7.01-6.92(\mathrm{~m}, 2 \mathrm{H}), 4.35(\mathrm{t}, J=6.8 \mathrm{~Hz}, 1 \mathrm{H}), 3.25(\mathrm{~s}$, $3 \mathrm{H}), 1.99-1.84(\mathrm{~m}, 1 \mathrm{H}), 1.72(\mathrm{~m}, 1 \mathrm{H}), 1.49-1.34(\mathrm{~m}, 1 \mathrm{H}), 1.33-1.23(\mathrm{~m}, 5 \mathrm{H}), 0.87(\mathrm{t}, J=6.7 \mathrm{~Hz}, 3 \mathrm{H})$ ppm.

${ }^{13} \mathrm{C} \mathrm{NMR}\left(\mathrm{CDCl}_{3}, 100 \mathrm{MHz}\right)$ : 146.4, 126.2, 125.2, 124.8, 79.5, 56.4, 38.3, 31.6, 25.5, 22.6, $14.0 \mathrm{ppm}$. HRMS Calculated for $\left[\mathrm{C}_{11} \mathrm{H}_{18} \mathrm{OS}+\mathrm{Na}\right]^{+}: 221.0971$, Found: 221.0969.<smiles>COC(C)c1ccc(C=O)s1</smiles>

5-(1-methoxyethyl)thiophene-2-carbaldehyde, 22.

Reaction run at $0.4 \mathrm{mmol}$ scale and $33.4 \mathrm{mg}(49 \%)$ of yellow liquid isolated.

${ }^{1} \mathrm{H} \mathrm{NMR}\left(\mathrm{CDCl}_{3}, 400 \mathrm{MHz}\right): 9.88(\mathrm{~s}, 1 \mathrm{H}), 7.66(\mathrm{~d}, J=3.8 \mathrm{~Hz}, 1 \mathrm{H}), 7.07$ (dd, $\left.J=3.8,0.7 \mathrm{~Hz}, 1 \mathrm{H}\right), 4.59$ (qd, $J=6.5,0.7 \mathrm{~Hz}, 1 \mathrm{H}), 3.33(\mathrm{~s}, 3 \mathrm{H}), 1.55(\mathrm{~d}, J=6.5 \mathrm{~Hz}, 3 \mathrm{H}) \mathrm{ppm}$.

${ }^{13} \mathrm{C} \mathrm{NMR}\left(\mathrm{CDCl}_{3}, 100 \mathrm{MHz}\right): 183.0,158.0,142.7,136.3,125.1,75.2,56.8,23.6 \mathrm{ppm}$.

HRMS Calculated for $\left[\mathrm{C}_{8} \mathrm{H}_{10} \mathrm{O}_{2} \mathrm{~S}+\mathrm{H}\right]^{+}: 171.0474$, Found: 171.0473.

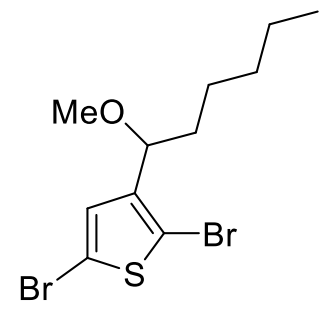


2,5-dibromo-3-(1-methoxyhexyl)thiophene, 23.

Reaction run at $0.2 \mathrm{mmol}$ scale and $52.6 \mathrm{mg}(74 \%)$ of colorless liquid isolated.

${ }^{1} \mathrm{H} \mathrm{NMR}\left(\mathrm{CDCl}_{3}, 400 \mathrm{MHz}\right): 8.43(\mathrm{~d}, J=7.8 \mathrm{~Hz}, 1 \mathrm{H}), 8.24(\mathrm{~s}, 1 \mathrm{H}), 6.88(\mathrm{~s}, 1 \mathrm{H}), 4.23$ (dd, $J=7.2,6.4 \mathrm{~Hz}$, $1 \mathrm{H}), 3.20$ (s, 3H), 1.76 (dddd, $J=13.4,9.8,7.2,5.2 \mathrm{~Hz}, 1 \mathrm{H}), 1.57$ (dddd, $J=13.4,10.0,6.4,5.3 \mathrm{~Hz}, 1 \mathrm{H}$ ), $1.42-1.19(\mathrm{~m}, 6 \mathrm{H}), 0.87(\mathrm{t}, J=6.8 \mathrm{~Hz}, 3 \mathrm{H}) \mathrm{ppm}$.

${ }^{13} \mathrm{C} \mathrm{NMR}\left(\mathrm{CDCl}_{3}, 100 \mathrm{MHz}\right)$ : 143.4, 128.8, 111.5, 109.4, 78.2, 56.8, 36.2, 31.6, 25.1, 22.6, $14.1 \mathrm{ppm}$. HRMS Calculated for $\left[\mathrm{C}_{11} \mathrm{H}_{16} \mathrm{Br}_{2} \mathrm{OS}+\mathrm{Na}\right]^{+}: 376.9181$, Found: 376.9180.

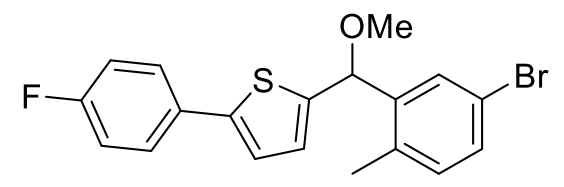

2-((5-bromo-2-methylphenyl)(methoxy)methyl)-5-(4-fluorophenyl)thiophene, 24.

Reaction run at $0.4 \mathrm{mmol}$ scale and $65.7 \mathrm{mg}(84 \%)$ of white solid isolated.

${ }^{1} \mathrm{H}$ NMR $\left(\mathrm{CDCl}_{3}, 400 \mathrm{MHz}\right): 7.72(\mathrm{~d}, J=2.2 \mathrm{~Hz}, 1 \mathrm{H}), 7.53-7.46(\mathrm{~m}, 2 \mathrm{H}), 7.34(\mathrm{dd}, J=8.1,2.2 \mathrm{~Hz}, 1 \mathrm{H})$, $7.07-6.99(\mathrm{~m}, 4 \mathrm{H}), 6.75(\mathrm{dd}, J=3.6,0.8 \mathrm{~Hz}, 1 \mathrm{H}), 5.51(\mathrm{~s}, 1 \mathrm{H}), 3.41(\mathrm{~s}, 3 \mathrm{H}), 2.24(\mathrm{~s}, 3 \mathrm{H}) \mathrm{ppm}$.

${ }^{13} \mathrm{C}$ NMR $\left(\mathrm{CDCl}_{3}, 100 \mathrm{MHz}\right): 162.3(\mathrm{~d}, J=245.7 \mathrm{~Hz}), 143.8,143.7,141.2,134.5,132.3,130.8,130.5(\mathrm{~d}$, $J=3.4 \mathrm{~Hz}), 129.1,127.4$ (d, $J=8.0 \mathrm{~Hz}), 126.9,122.3$ (d, $J=1.2 \mathrm{~Hz}), 120.1,115.8$ (d, $J=21.7 \mathrm{~Hz}), 78.0$, 57.0, 18.8 ppm.

${ }^{19} \mathrm{~F}$ NMR (377 MHz, $\left.\mathrm{CDCl}_{3}\right):-114.5 \mathrm{ppm}$.

HRMS Calculated for $\left[\mathrm{C}_{19} \mathrm{H}_{16} \mathrm{BrFOS}+\mathrm{Na}\right]^{+}: 412.9982$, Found: 412.9980.<smiles>COC1CCOc2ccccc21</smiles>

4-methoxychromane, 25.

Reaction run at $0.4 \mathrm{mmol}$ scale and $30.2 \mathrm{mg}(46 \%)$ of colorless liquid isolated.

${ }^{1} \mathrm{H}$ NMR $\left(\mathrm{CDCl}_{3}, 400 \mathrm{MHz}\right): 7.24(\mathrm{dd}, J=7.7,1.7 \mathrm{~Hz}, 1 \mathrm{H}), 7.28(\mathrm{td}, J=7.7,1.7 \mathrm{~Hz}, 1 \mathrm{H}), 6.89$ (td, $J=7.4$, $1.2 \mathrm{~Hz}, 1 \mathrm{H}), 6.84(\mathrm{dd}, J=8.2,1.2 \mathrm{~Hz}, 1 \mathrm{H}), 4.32-4.21(\mathrm{~m}, 3 \mathrm{H}), 3.44(\mathrm{~s}, 3 \mathrm{H}), 2.18-2.10$ (m, 1H), $2.09-$ $1.98(\mathrm{~m}, 1 \mathrm{H}) \mathrm{ppm}$.

${ }^{13} \mathrm{C} \mathrm{NMR}\left(\mathrm{CDCl}_{3}, 100 \mathrm{MHz}\right):$ 154.8, 130.6, 129.7, 121.6, 119.9, 117.0, 71.8, 62.0, 55.8, $27.2 \mathrm{ppm}$. HRMS (ASAP-MS) Calculated for $\left[\mathrm{C}_{10} \mathrm{H}_{12} \mathrm{O}_{2}-\mathrm{OMe}\right]^{+}: 133.0648$, Found: 133.0646.<smiles>COC1CCOc2ccc(Br)cc21</smiles>

6-bromo-4-methoxychromane, 26.

Reaction run at $0.4 \mathrm{mmol}$ scale and $50.6 \mathrm{mg}(52 \%)$ of colorless liquid isolated. 
${ }^{1} \mathrm{H}$ NMR $\left(\mathrm{CDCl}_{3}, 400 \mathrm{MHz}\right): 7.37(\mathrm{~d}, J=2.4 \mathrm{~Hz}, 1 \mathrm{H}), 7.28(\mathrm{dd}, J=8.8,3.2 \mathrm{~Hz}, 1 \mathrm{H}), 6.72(\mathrm{~d}, J=8.7 \mathrm{~Hz}$, $1 \mathrm{H}), 4.29-4.19$ (m, 3H), 3.44 (s, 3H), $2.16-2.08$ (m, 1H), 2.01 (dddd, $J=14.2,9.6,5.4,3.8 \mathrm{~Hz}, 1 \mathrm{H}) \mathrm{ppm}$. ${ }^{13} \mathrm{C} \mathrm{NMR}\left(\mathrm{CDCl}_{3}, 100 \mathrm{MHz}\right): 153.9,132.9,132.5,123.7,118.9,111.9,71.5,62.3,56.0,26.8 \mathrm{ppm}$.

HRMS (ASAP-MS) Calculated for $\left[\mathrm{C}_{10} \mathrm{H}_{11} \mathrm{BrO}_{2}-\mathrm{OMe}\right]^{+}: 210.9753$, Found: 210.9752.<smiles>COC(C)c1ccc2nc(NC(C)=O)sc2c1</smiles>

$N$-[6-(1-methoxyethyl)-1,3-benzothiazol-2-yl]acetamide, 27.

Reaction run at $0.4 \mathrm{mmol}$ scale and $40.3 \mathrm{mg}(40 \%)$ of white solid isolated.

${ }^{1} \mathrm{H}$ NMR $\left(\mathrm{CDCl}_{3}, 400 \mathrm{MHz}\right): 11.77(\mathrm{~s}, 1 \mathrm{H}), 7.80(\mathrm{~d}, J=1.7 \mathrm{~Hz}, 2 \mathrm{H}), 7.74(\mathrm{~d}, J=8.3 \mathrm{~Hz}, 1 \mathrm{H}), 7.41(\mathrm{dd}, J$ $=8.4 \mathrm{~Hz}, J=1.7 \mathrm{~Hz}, 1 \mathrm{H}), 4.43(\mathrm{q}, J=6.4 \mathrm{~Hz}, 1 \mathrm{H}), 3.27(\mathrm{~s}, 3 \mathrm{H}), 2.30(\mathrm{~s}, 3 \mathrm{H}), 1.50(\mathrm{~d}, J=6.4 \mathrm{~Hz}, 3 \mathrm{H}) \mathrm{ppm}$.

${ }^{13} \mathrm{C} \mathrm{NMR}\left(\mathrm{CDCl}_{3}, 100 \mathrm{MHz}\right): 168.89,159.91,147.17,139.91,132.07,124.80,120.28,119.22,79.52,56.59$, 24.00, $23.57 \mathrm{ppm}$.

HRMS Calculated for $+\left[\mathrm{C}_{12} \mathrm{H}_{14} \mathrm{~N}_{2} \mathrm{O}_{2} \mathrm{~S}+\mathrm{H}\right]^{+}: 251.0849$, Found: 251.0846<smiles>COC(=O)Cn1nc(C(F)(F)F)c2c1CCCC2OC</smiles>

$N$-[6-(1-methoxyethyl)-1,3-benzothiazol-2-yl]acetamide, 28.

Reaction run at $0.4 \mathrm{mmol}$ scale and $72.9 \mathrm{mg}(62 \%)$ of yellow liquid isolated.

${ }^{1} \mathrm{H}$ NMR $\left(\mathrm{CDCl}_{3}, 400 \mathrm{MHz}\right): 4.88(\mathrm{~d}, J=17.5 \mathrm{~Hz}, 1 \mathrm{H}), 4.78(\mathrm{~d}, J=17.5 \mathrm{~Hz}, 1 \mathrm{H}), 4.43(\mathrm{t}, J=3.4 \mathrm{~Hz}, 1 \mathrm{H})$, $3.77(\mathrm{~s}, 3 \mathrm{H}), 3.42(\mathrm{~s}, 3 \mathrm{H}), 2.61(\mathrm{ddd}, J=16.3 \mathrm{~Hz}, J=5.8 \mathrm{~Hz}, J=3.0 \mathrm{~Hz}, 1 \mathrm{H}), 2.46$ (ddd, $J=16.5 \mathrm{~Hz}, J=$ $10.7 \mathrm{~Hz}, J=6.1 \mathrm{~Hz}, 1 \mathrm{H}), 2.14(\mathrm{ddd}, J=14.1 \mathrm{~Hz}, J=5.4 \mathrm{~Hz}, J=2.8 \mathrm{~Hz}, 1 \mathrm{H}), 2.00$ (tdd, $J=10.5 \mathrm{~Hz}, J=$ $8.1 \mathrm{~Hz}, J=5.3 \mathrm{~Hz}, 1 \mathrm{H}), 1.95-1.79(\mathrm{~m}, 1 \mathrm{H}), 1.68-1.54(\mathrm{~m}, 1 \mathrm{H}) \mathrm{ppm}$.

${ }^{13} \mathrm{C} \mathrm{NMR}\left(\mathrm{CDCl}_{3}, 100 \mathrm{MHz}\right): 167.3,142.7,140.0$ (q, $\left.J=37.3 \mathrm{~Hz}\right), 121.6(\mathrm{q}, J=269.4 \mathrm{~Hz}), 116.2,69.3$, $56.5,52.8,50.5,26.5,21.0,17.0 \mathrm{ppm}$.

${ }^{19} \mathrm{~F} \mathrm{NMR}\left(377 \mathrm{MHz}, \mathrm{CDCl}_{3}\right)$ : $-61.5 \mathrm{ppm}$.

HRMS Calculated for $+\left[\mathrm{C}_{12} \mathrm{H}_{15} \mathrm{~F}_{3} \mathrm{~N}_{2} \mathrm{O}_{3}+\mathrm{H}\right]^{+}: 293.1108$, Found: 293.1102<smiles>COC(C#N)c1nn(C)c2ccccc12</smiles>

methoxy(1-methyl-1H-indazol-3-yl)acetonitrile, 29.

Reaction run at $0.4 \mathrm{mmol}$ scale and $30.5 \mathrm{mg}(38 \%)$ of orange to green liquid isolated.

${ }^{1} \mathrm{H} \mathrm{NMR}\left(\mathrm{CDCl}_{3}, 400 \mathrm{MHz}\right): 7.90$ (d, $\left.J=8.2 \mathrm{~Hz}, 1 \mathrm{H}\right), 7.43$ (m, 2H), 7.24 (m, 1H), $5.63(\mathrm{~s}, 1 \mathrm{H}), 4.08$ (s, 
3H), 3.57 (s, 3H) ppm.

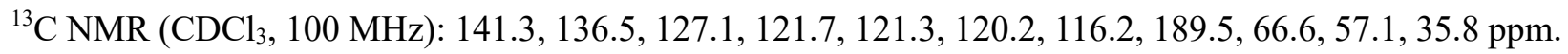
HRMS Calculated for $+\left[\mathrm{C}_{11} \mathrm{H}_{11} \mathrm{~N}_{3} \mathrm{O}_{2}+\mathrm{H}\right]^{+}: 202.0975$, Found: 202.0975<smiles>COc1ccc(C(=O)C(OC)c2ccc(OC)cc2)cc1</smiles>

\{2-methoxy-1, 2-bis(4-methoxyphenyl) ethenone\}, 30. Characterization data matched those previously reported ${ }^{15}$.

Reaction run at $0.4 \mathrm{mmol}$ scale and $66.6 \mathrm{mg}(58 \%)$ of colorless liquid isolated.

${ }^{1} \mathrm{H}$ NMR $\left(\mathrm{CDCl}_{3}, 400 \mathrm{MHz}\right): 7.99(\mathrm{~d}, J=8.96 \mathrm{~Hz}, 2 \mathrm{H}), 7.38(\mathrm{~d}, J=8.62 \mathrm{~Hz}, 2 \mathrm{H}), 6.87$ (d, $J=2.85 \mathrm{~Hz}$, $2 \mathrm{H}), 6.85(\mathrm{~d}, J=3.03 \mathrm{~Hz}, 2 \mathrm{H}), 5.45(\mathrm{~s}, 3 \mathrm{H}), 3.81(\mathrm{~s}, 3 \mathrm{H}), 3.76(\mathrm{~s}, 3 \mathrm{H}), 3.42(\mathrm{~s}, 3 \mathrm{H}) \mathrm{ppm}$.

${ }^{13} \mathrm{C} \mathrm{NMR}\left(\mathrm{CDCl}_{3}, 100 \mathrm{MHz}\right): 195.5,163.5,159.7,131.3,129.0,128.5,127.9,114.3,113.7,85.8,57.2,55.4$, $55.2 \mathrm{ppm}$.

HRMS Calculated for $\left[\mathrm{C}_{17} \mathrm{H}_{18} \mathrm{O}_{4}+\mathrm{Na}\right]^{+}: 309.1097$, Found: 309.1092.<smiles>CCOc1ccc(C(OC)c2cc([C@H]3O[C@H](COC(C)=O)[C@@H](OC(C)=O)[C@H](OC(C)=O)[C@H]3OC(C)=O)ccc2Cl)cc1</smiles>

(2R,3R,4R,5S,6S)-2-(acetoxymethyl)-6-(4-chloro-3-((4-ethoxyphenyl)(methoxy)methyl)phenyl) tetrahydro-2 $H$-pyran-3,4,5-triyl triacetate, 31.

Reaction run at $0.4 \mathrm{mmol}$ scale and $233 \mathrm{mg}$ (91\%) of white solid was isolated. (a mixture of two diastereomers): d. r. $=1.1: 1$ (by ${ }^{1} \mathrm{H}$ NMR spectroscopy. Reported spectral values are of the mixture).

Major diastereomer: ${ }^{1} \mathrm{H}$ NMR $\left(\mathrm{CDCl}_{3}, 400 \mathrm{MHz}\right): 7.54$ (d, $J=2.1 \mathrm{~Hz}, 1 \mathrm{H}$, major diastereomer), 7.48 (d, $J$ $=2.1 \mathrm{~Hz}, 1 \mathrm{H}$, minor diastereomer), $7.34(\mathrm{dd}, J=10.1,1 \mathrm{H}$, minor diastereomer), $7.32(\mathrm{dd}, J=10.1,1 \mathrm{H}$, major diastereomer), $7.28-7.17(\mathrm{~m}, 3 \mathrm{H}), 6.88-6.77(\mathrm{~m}, 2 \mathrm{H}), 5.61(\mathrm{~s}, 1 \mathrm{H}$, minor diastereomer), $5.55(\mathrm{~s}$, $1 \mathrm{H}$, major diastereomer), $5.32(\mathrm{t}, J=9.3 \mathrm{~Hz}, 1 \mathrm{H}$, minor diastereomer), $5.31(\mathrm{t}, J=9.3 \mathrm{~Hz}, 1 \mathrm{H}$, major diastereomer), $5.23(\mathrm{t}, J=9.7,1 \mathrm{H}), 5.11(\mathrm{t}, 9.6 \mathrm{~Hz}, 1 \mathrm{H}$, major diastereomer), $5.06(\mathrm{t}, 9.6 \mathrm{~Hz}, 1 \mathrm{H}), 4.40(\mathrm{~d}$, $J=9.8 \mathrm{~Hz}, 1 \mathrm{H}), 4.27(\mathrm{dd}, J=12.4,4.9,1 \mathrm{H}), 4.18(\mathrm{dd}, J=12.4,2.4 \mathrm{~Hz}, 1 \mathrm{H}), 4.00(\mathrm{q}, J=7.0 \mathrm{~Hz}, 2 \mathrm{H}$, major diastereomer), $3.98(\mathrm{q}, J=7.0 \mathrm{~Hz}, 2 \mathrm{H}), 3.82(\mathrm{ddd}, J=9.9,4.8,2.1 \mathrm{~Hz}, 1 \mathrm{H}), 3.37$ (s, 3H, minor diastereomer), $3.32(\mathrm{~s}, 3 \mathrm{H}$, major diastereomer), $2.09(\mathrm{~s}, 3 \mathrm{H}), 2.06(\mathrm{~s}, 3 \mathrm{H}), 2.01(\mathrm{~s}, 3 \mathrm{H}$, minor diastereomer), $1.99(\mathrm{~s}, 3 \mathrm{H}$, major diastereomer), $1.87(\mathrm{~s}, 3 \mathrm{H}$, major diastereomer), 1.61 (s, $3 \mathrm{H}$, minor diastereomer), $1.38(\mathrm{t}, J=7.0$, $3 \mathrm{H})$.

${ }^{13} \mathrm{C} \mathrm{NMR}\left(\mathrm{CDCl}_{3}, 100 \mathrm{MHz}\right): 170.73,170.36,170.34,169.51,168.90,168.81,158.53,158.47,139.85$, $139.61,135.57,135.37,133.43,133.20,132.42$, 131.94, 129.90, 129.79, 128.81, 128.33, 126.95, 126.79, 
$126.72,126.68,114.50,114.30,114.24,80.81,80.63,79.43,76.15,76.11,74.17,74.14,72.66,72.56,68.54$, 63.40, 63.38, 62.29, 57.12, 56.74, 20.79, 20.67, 20.66, 20.43, 20.19, 14.84, 14.81.

HRMS Calculated for $\left[\mathrm{C}_{30} \mathrm{H}_{35} \mathrm{ClO}_{11}+\mathrm{NH}_{4}\right]^{+}: 624.2206$, Found: 624.2203.<smiles>COC(=O)C(C)c1ccc(C(OC)C(C)C)cc1</smiles>

Methyl 2-[4-(1-methoxy-2-methylpropyl)phenyl]propanoate, 32.

Reaction run at $0.4 \mathrm{mmol}$ scale and $33.5 \mathrm{mg}(67 \%)$ of colorless liquid was isolated.

${ }^{1} \mathrm{H}$ NMR $\left(\mathrm{CDCl}_{3}, 400 \mathrm{MHz}\right): 7.26$ (d, $\left.J=8.3 \mathrm{~Hz}, 2 \mathrm{H}\right), 7.19$ (d, $\left.J=8.2 \mathrm{~Hz}, 2 \mathrm{H}\right), 3.73(\mathrm{~m}, 2 \mathrm{H}), 3.67$ (s, 3H), 3.18 (s, 3H), 1.89 (doublet of septets, $J=6.8 \mathrm{~Hz}, 1 \mathrm{H}), 1.50$ (d, $J=7.2 \mathrm{~Hz}, 3 \mathrm{H}), 0.98(\mathrm{~d}, J=6.7 \mathrm{~Hz}, 3 \mathrm{H})$, $0.73(\mathrm{~d}, J=6.8 \mathrm{~Hz}, 3 \mathrm{H}) \mathrm{ppm}$.

${ }^{13} \mathrm{C} \mathrm{NMR}\left(\mathrm{CDCl}_{3}, 100 \mathrm{MHz}\right): 175.1,140.0,139.4,127.7,127.1,89.4,57.0,52.0,45.1,34.7,19.0,18.9$, $18.6 \mathrm{ppm}$.

HRMS Calculated for $\left[\mathrm{C}_{15} \mathrm{H}_{22} \mathrm{O}_{3}+\mathrm{NH}_{4}\right]^{+}: 268.1907$, Found: 268.1904.<smiles>COC1CC(C)(C)c2cc(C(C)(C)C)cc(C(C)=O)c21</smiles>

1-(6-tert-butyl-3-methoxy-1,1-dimethyl-2,3-dihydro-1H-inden-4-yl)ethan-1-one, 33.

Reaction run at $0.4 \mathrm{mmol}$ scale and $84.1 \mathrm{mg}(77 \%)$ of colorless liquid isolated.

${ }^{1} \mathrm{H}$ NMR $\left(\mathrm{CDCl}_{3}, 400 \mathrm{MHz}\right): 7.66(\mathrm{~d}, J=1.8 \mathrm{~Hz}, 1 \mathrm{H}), 7.36(\mathrm{~d}, J=1.8 \mathrm{~Hz}, 1 \mathrm{H}), 5.21(\mathrm{dd}, J=5.7,3.1 \mathrm{~Hz}$, 1H), $3.42(\mathrm{~s}, 3 \mathrm{H}), 2.62(\mathrm{~s}, 3 \mathrm{H}), 2.18-1.99(\mathrm{~m}, 2 \mathrm{H}), 1.34(\mathrm{~s}, 9 \mathrm{H}), 1.35(\mathrm{~s}, 3 \mathrm{H}), 1.30(\mathrm{~s}, 3 \mathrm{H}) \mathrm{ppm}$.

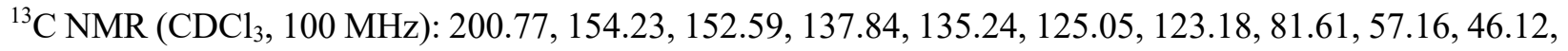
42.63, 34.94, 31.42, 31.19, 29.77, $28.77 \mathrm{ppm}$.

HRMS Calculated for $+\left[\mathrm{C}_{17} \mathrm{H}_{23} \mathrm{O}_{2}-\mathrm{OCH}_{3}\right]^{+}: 243.1743$, Found: 243.1740 .<smiles>COc1cc(C(=O)c2c(C(C)C)oc3ccccc23)cc(Br)c1Br</smiles>

1-(6-tert-butyl-3-methoxy-1,1-dimethyl-2,3-dihydro-1H-inden-4-yl)ethan-1-one, 34.

Reaction run at $0.4 \mathrm{mmol}$ scale and $61.0 \mathrm{mg}(65 \%)$ of white solid isolated.

${ }^{1} \mathrm{H}$ NMR ( $\left.\mathrm{CDCl}_{3}, 400 \mathrm{MHz}\right): 8.03$ (s, 2H), 7.71-7.48 (m, 1H), 7.43-7.33 (m, 2H), 7.32-7.24 (m, 1H), 4.73 
(q, $J=6.6 \mathrm{~Hz}, 1 \mathrm{H}), 3.99(\mathrm{~s}, 3 \mathrm{H}), 3.29(\mathrm{~s}, 3 \mathrm{H}), 1.63(\mathrm{~d}, J=6.6 \mathrm{~Hz}, 3 \mathrm{H}) \mathrm{ppm}$.

${ }^{13} \mathrm{C} \mathrm{NMR}\left(\mathrm{CDCl}_{3}, 100 \mathrm{MHz}\right): 187.6,162.5,158.1,154.0,136.6,133.8,125.7,125.67,124.1,121.3,118.7$, 117.6, 111.9, 71.3, 60.9, 57.0, $19.4 \mathrm{ppm}$.

HRMS Calculated for $+\left[\mathrm{C}_{19} \mathrm{H}_{16} \mathrm{Br}_{2} \mathrm{O}_{4}+\mathrm{H}\right]^{+}:$466.9488, Found: 466.9484 .<smiles>COC1CCN(S(=O)(=O)c2ccc(Cl)c([N+](=O)[O-])c2)c2ccccc21</smiles>

1-(4-chloro-3-nitrobenzene-1-sulfonyl)-4-methoxy-1,2,3,4-tetrahydroquinoline, 35.

Reaction run at $0.4 \mathrm{mmol}$ scale and $36.8 \mathrm{mg}(48 \%)$ of white solid isolated.

${ }^{1} \mathrm{H}$ NMR $\left(\mathrm{CDCl}_{3}, 400 \mathrm{MHz}\right): 8.02(\mathrm{~d}, J=2.1 \mathrm{~Hz}, 2 \mathrm{H}), 7.89(\mathrm{~d}, J=8.3 \mathrm{~Hz}, 2 \mathrm{H}), 7.65(\mathrm{dd}, J=8.5 \mathrm{~Hz}, J=$ $2.1 \mathrm{~Hz}, 2 \mathrm{H}), 7.56(\mathrm{~d}, J=8.5 \mathrm{~Hz}, 2 \mathrm{H}), 7.36(\mathrm{ddd}, J=8.4 \mathrm{~Hz}, J=5.6 \mathrm{~Hz}, J=2.8 \mathrm{~Hz}, 3 \mathrm{H}), 7.16(\mathrm{~m}, 2 \mathrm{H}), 4.04$ $(\mathrm{t}, J=6.8 \mathrm{~Hz}, 1 \mathrm{H}), 3.96(\mathrm{ddd}, J=12.3 \mathrm{~Hz}, J=5.9 \mathrm{~Hz}, J=3.0 \mathrm{~Hz}, 1 \mathrm{H}), 3.72(\mathrm{td}, J=12.3 \mathrm{~Hz}, J=4.9 \mathrm{~Hz}$, 1H), 2.94 (s, 3H), 2.16 (m, 1H), 1.75 (dddd, $J=14.0 \mathrm{~Hz}, J=12.3 \mathrm{~Hz}, J=5.9 \mathrm{~Hz}, J=2.9 \mathrm{~Hz}, 1 \mathrm{H}) \mathrm{ppm}$.

${ }^{13} \mathrm{C} \mathrm{NMR}\left(\mathrm{CDCl}_{3}, 100 \mathrm{MHz}\right)$ : 147.6, 138.1, 135.3, 132.3, 131.4, 131.2, 129.9, 129.6, 129.5, 125.2, 124.4, 124.3, 73.8, 55.7, 42.3, $27.9 \mathrm{ppm}$.

HRMS Calculated for $\left[\mathrm{C}_{16} \mathrm{H}_{15} \mathrm{ClN}_{2} \mathrm{O}_{5} \mathrm{~S}+\mathrm{NH}_{4}\right]^{+}: 400.0729$, Found: 400.0721.

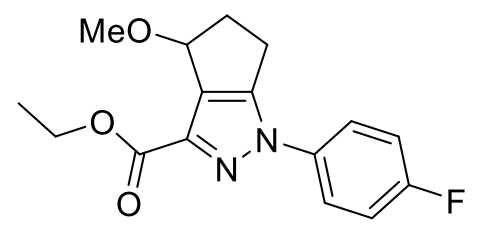

Ethyl-1-(4-fluorophenyl)-4-methoxy-1,3a,4,5,6,6a-hexahydrocyclopenta[c]pyrazole-3-carboxylate, 36a. Reaction run at $0.4 \mathrm{mmol}$ scale and $97.7 \mathrm{mg}(80 \%)$ of colorless liquid isolated.

${ }^{1} \mathrm{H}$ NMR $\left(\mathrm{CDCl}_{3}, 400 \mathrm{MHz}\right): 7.65(\mathrm{dd}, J=8.4 \mathrm{~Hz}, J=4.3 \mathrm{~Hz}, 2 \mathrm{H}), 7.14$ (t, $\left.J=8.2 \mathrm{~Hz}, 2 \mathrm{H}\right), 4.84(\mathrm{~d}, J=$ $5.7 \mathrm{~Hz}, 1 \mathrm{H}), 4.43$ (q, $J=7.1 \mathrm{~Hz}, 2 \mathrm{H}), 3.22(\mathrm{~m}, 1 \mathrm{H}), 2.83(\mathrm{~m}, 2 \mathrm{H}), 2.63(\mathrm{~m}, 1 \mathrm{H}), 1.40$ (t, $J=7.0 \mathrm{~Hz}, 3 \mathrm{H})$ ppm.

${ }^{13} \mathrm{C} \mathrm{NMR}\left(\mathrm{CDCl}_{3}, 100 \mathrm{MHz}\right): 162.1,161.5(\mathrm{~d}, J=247.4 \mathrm{~Hz}), 152.2,138.8,135.7$ (d, $\left.J=3.0 \mathrm{~Hz}\right), 131.3$, $122.3(\mathrm{~d}, J=8.5 \mathrm{~Hz}), 116.2$ (d, $J=23.1 \mathrm{~Hz}), 76.1,61.1,56.6,38.9,24.6,14.3 \mathrm{ppm}$.

${ }^{19} \mathrm{~F}$ NMR (377 MHz, $\left.\mathrm{CDCl}_{3}\right)$ : $-114.3 \mathrm{ppm}$.

HRMS Calculated for $\left[\mathrm{C}_{16} \mathrm{H}_{17} \mathrm{FN}_{2} \mathrm{O}_{3}+\mathrm{H}\right]^{+}:$305.1296, Found: 305.1290. 


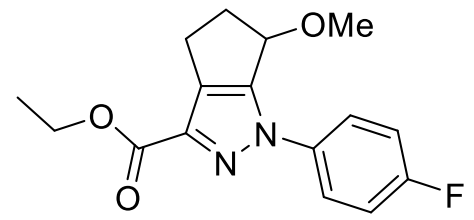

Ethyl-1-(4-fluorophenyl)-6-methoxy-1,3a,4,5,6,6a-hexahydrocyclopenta[c]pyrazole-3-carboxylate, 36b.

Reaction run at $0.4 \mathrm{mmol}$ scale and $11.0 \mathrm{mg}(9 \%)$ of colorless liquid isolated.

${ }^{1} \mathrm{H} \mathrm{NMR}\left(\mathrm{CDCl}_{3}, 400 \mathrm{MHz}\right): 7.84$ (m, 2H), $7.14(\mathrm{~m}, 2 \mathrm{H}), 4.95(\mathrm{~m}, 1 \mathrm{H}), 4.41$ (q, J=7.1 Hz, 2H), 3.00 (m, $1 \mathrm{H}), 2.82(\mathrm{~m}, 2 \mathrm{H}), 2.63(\mathrm{~m}, 1 \mathrm{H}), 1.40(\mathrm{t}, J=7.1 \mathrm{~Hz}, 3 \mathrm{H}) \mathrm{ppm}$.

${ }^{13} \mathrm{C} \mathrm{NMR}\left(\mathrm{CDCl}_{3}, 100 \mathrm{MHz}\right): 162.3,161.6(\mathrm{~d}, J=247.0 \mathrm{~Hz}), 148.5,138.0,135.9(\mathrm{~d}, J=3.0 \mathrm{~Hz}), 134.7$, 122.5 (d, $J=8.4 \mathrm{~Hz}), 116.1$ (d, $J=22.9 \mathrm{~Hz}), 75.7,61.0,54.6,36.9,22.4,14.4$ ppm.

HRMS Calculated for $\left[\mathrm{C}_{16} \mathrm{H}_{17} \mathrm{FN}_{2} \mathrm{O}_{3}+\mathrm{H}\right]^{+}:$305.1296, Found: 305.1291 .<smiles>CCc1nn(C)c(C(=O)NC(OC)c2ccc(C(C)(C)C)cc2)c1Cl</smiles>

4-chloro-3-ethyl-N-[methoxy(4-tert-butylphenyl)methyl]-1-methyl-1H-pyrazole-5-carboxamide, 37.

Reaction run at $0.2 \mathrm{mmol}$ scale and $32.7 \mathrm{mg}(45 \%)$ of white solid isolated.

${ }^{1} \mathrm{H} \mathrm{NMR}\left(\mathrm{CDCl}_{3}, 500 \mathrm{MHz}\right) \delta 7.42(\mathrm{~s}, 4 \mathrm{H}), 7.22(\mathrm{~d}, J=9.0 \mathrm{~Hz}, 1 \mathrm{H}), 6.28(\mathrm{~d}, J=9.1 \mathrm{~Hz}, 1 \mathrm{H}), 4.15(\mathrm{~s}, 3 \mathrm{H})$, $3.53(\mathrm{~s}, 3 \mathrm{H}), 2.63$ (q, $J=7.6 \mathrm{~Hz}, 2 \mathrm{H}), 1.32(\mathrm{~s}, 9 \mathrm{H}), 1.23(\mathrm{t}, J=7.6 \mathrm{~Hz}, 3 \mathrm{H}) \mathrm{ppm}$.

${ }^{13} \mathrm{C} \mathrm{NMR}\left(\mathrm{CDCl}_{3}, 125 \mathrm{MHz}\right): 158.55,151.86,149.71,135.66,130.52,125.75,125.70,125.62,125.58$, 108.16, 81.63, 56.21, 40.79, 34.65, 31.30, 19.23, 12.84 ppm.

HRMS Calculated for $\left[\mathrm{C}_{19} \mathrm{H}_{26} \mathrm{ClN}_{3} \mathrm{O}_{2}+\mathrm{H}\right]^{+}: 364.1786$, Found: 364.1782 .<smiles>Cc1ccc(Br)cc1C(OCCCl)c1ccc(-c2ccc(F)cc2)s1</smiles>

2-((5-bromo-2-methylphenyl)(2-chloroethoxy)methyl)-5-(4-fluorophenyl)thiophene, 38.

Reaction run at $0.2 \mathrm{mmol}$ scale and $75.6 \mathrm{mg}(86 \%)$ of colorless liquid isolated.

${ }^{1} \mathrm{H}$ NMR $\left(\mathrm{CDCl}_{3}, 400 \mathrm{MHz}\right): 7.74(\mathrm{~d}, J=2.2 \mathrm{~Hz}, 1 \mathrm{H}), 7.53-7.46(\mathrm{~m}, 2 \mathrm{H}), 7.35(\mathrm{dd}, J=8.0,2.2 \mathrm{~Hz}, 1 \mathrm{H})$, $7.07-6.99(\mathrm{~m}, 4 \mathrm{H}), 6.77(\mathrm{dd}, J=3.8,0.8 \mathrm{~Hz}, 1 \mathrm{H}), 5.71(\mathrm{~s}, 1 \mathrm{H}), 3.81-3.72(\mathrm{~m}, 2 \mathrm{H}), 3.69$ (td, $J=5.8,1.0$ $\mathrm{Hz}, 1 \mathrm{H}), 2.24(\mathrm{~s}, 3 \mathrm{H}) \mathrm{ppm}$.

${ }^{13} \mathrm{C}$ NMR $\left(\mathrm{CDCl}_{3}, 100 \mathrm{MHz}\right): 162.4(\mathrm{~d}, J=245.8 \mathrm{~Hz}), 144.1,143.2,140.9,134.5,132.3,131.0,130.5(\mathrm{~d}$, $J=3.4 \mathrm{~Hz}), 129.3,127.4(\mathrm{~d}, J=8.0 \mathrm{~Hz}), 127.1,122.4(\mathrm{~d}, J=1.2 \mathrm{~Hz}), 120.2,115.8(\mathrm{~d}, J=21.7 \mathrm{~Hz}), 76.9$, 69.2, 42.8, $18.8 \mathrm{ppm}$.

${ }^{19} \mathrm{~F}$ NMR (377 MHz, $\left.\mathrm{CDCl}_{3}\right)$ : $-114.3 \mathrm{ppm}$.

HRMS Calculated for $\left[\mathrm{C}_{20} \mathrm{H}_{18} \mathrm{BrClFOS}+\mathrm{Na}\right]^{+}: 460.9748$, Found: 460.9744. 
<smiles>COCCOC(c1ccc(-c2ccc(F)cc2)s1)c1cc(Br)ccc1C</smiles>

2-((5-bromo-2-methylphenyl)(2-methoxyethoxy)methyl)-5-(4-fluorophenyl)thiophene, 39.

Reaction run at $0.2 \mathrm{mmol}$ scale and $62.7 \mathrm{mg}(72 \%)$ of colorless liquid isolated.

${ }^{1} \mathrm{H}$ NMR $\left(\mathrm{CDCl}_{3}, 400 \mathrm{MHz}\right): 7.75(\mathrm{~d}, J=2.2 \mathrm{~Hz}, 1 \mathrm{H}), 7.53-7.46(\mathrm{~m}, 2 \mathrm{H}), 7.34(\mathrm{dd}, J=8.1,2.2 \mathrm{~Hz}, 1 \mathrm{H})$, $7.07-6.99(\mathrm{~m}, 4 \mathrm{H}), 6.76(\mathrm{dd}, J=3.7,0.8 \mathrm{~Hz}, 1 \mathrm{H}), 5.72(\mathrm{~s}, 1 \mathrm{H}), 3.73-3.59(\mathrm{~m}, 4 \mathrm{H}), 3.40(\mathrm{~s}, 3 \mathrm{H}), 2.24(\mathrm{~s}$, 3H) $\mathrm{ppm}$.

${ }^{13} \mathrm{C} \mathrm{NMR}\left(\mathrm{CDCl}_{3}, 100 \mathrm{MHz}\right): 162.3(\mathrm{~d}, J=245.7 \mathrm{~Hz}), 143.8,141.4,134.5,132.2,130.8,130.6(\mathrm{~d}, J=3.4$ $\mathrm{Hz}), 129.3,127.4$ (d, $J=8.0 \mathrm{~Hz}), 127.0,122.32,122.30,120.1,115.8$ (d, $J=21.7 \mathrm{~Hz}), 76.6,72.1,68.5$, $59.1,18.8 \mathrm{ppm}$.

${ }^{19} \mathrm{~F}$ NMR (377 MHz, $\mathrm{CDCl}_{3}$ ): $-114.6 \mathrm{ppm}$.

HRMS Calculated for $\left[\mathrm{C}_{21} \mathrm{H}_{20} \mathrm{BrFNO}_{2} \mathrm{~S}+\mathrm{Na}\right]^{+}: 457.0244$, Found: 457.0242.<smiles>CC(=O)NCCOC(c1ccc(-c2ccc(F)cc2)s1)c1cc(Br)ccc1C</smiles>

tert-butyl(2-((5-bromo-2-methylphenyl)(5-(4-fluorophenyl)thiophen-2-yl)methoxy)ethyl)carbamate, 40. Reaction run at $0.2 \mathrm{mmol}$ scale and $72.7 \mathrm{mg}(70 \%)$ of yellow liquid isolated.

${ }^{1} \mathrm{H}$ NMR $\left(\mathrm{CDCl}_{3}, 400 \mathrm{MHz}\right): 7.70(\mathrm{~d}, J=2.2 \mathrm{~Hz}, 1 \mathrm{H}), 7.53-7.46(\mathrm{~m}, 2 \mathrm{H}), 7.35(\mathrm{dd}, J=8.1,2.2 \mathrm{~Hz}, 1 \mathrm{H})$, $7.08-6.99$ (m, 4H), 6.76 (dd, $J=3.6,0.8 \mathrm{~Hz}, 1 \mathrm{H}), 5.63(\mathrm{~s}, 1 \mathrm{H}), 5.03-4.83(\mathrm{~m}, 1 \mathrm{H}), 3.60$ (dt, $J=9.5,5.1$ $\mathrm{Hz}, 1 \mathrm{H}), 3.55$ (dt, $J=9.5,4.9 \mathrm{~Hz}, 1 \mathrm{H}), 3.40(\mathrm{~d}, J=5.5 \mathrm{~Hz}, 1 \mathrm{H}), 3.38(\mathrm{~d}, J=5.5 \mathrm{~Hz}, 1 \mathrm{H}), 2.24$ (s, 3H), 1.43 (s, 9H) ppm.

${ }^{13} \mathrm{C}$ NMR $\left(\mathrm{CDCl}_{3}, 100 \mathrm{MHz}\right): 162.4(\mathrm{~d}, J=245.8 \mathrm{~Hz}), 156.0,144.0,143.6,141.2,134.4,132.3,130.9$, $130.5(\mathrm{~d}, J=3.4 \mathrm{~Hz}), 129.0,127.4(\mathrm{~d}, J=8.0 \mathrm{~Hz}), 127.0,122.3(\mathrm{~d}, J=1.2 \mathrm{~Hz}), 120.1,115.8(\mathrm{~d}, J=21.6$ $\mathrm{Hz}), 79.4,76.5,68.5,40.5,28.4,18.8 \mathrm{ppm}$.

${ }^{19} \mathrm{~F}$ NMR (377 MHz, $\left.\mathrm{CDCl}_{3}\right)$ : $-114.4 \mathrm{ppm}$.

HRMS Calculated for $\left[\mathrm{C}_{25} \mathrm{H}_{27} \mathrm{BrFNO}_{3} \mathrm{~S}+\mathrm{Na}\right]^{+}:$542.0771, Found: 542.0768 .

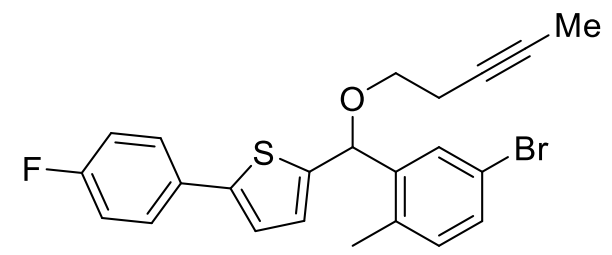

2-((5-bromo-2-methylphenyl)(pent-3-yn-1-yloxy)methyl)-5-(4-fluorophenyl)thiophene, 41.

Reaction run at $0.2 \mathrm{mmol}$ scale and $45.2 \mathrm{mg}(51 \%)$ of colorless liquid isolated.

${ }^{1} \mathrm{H}$ NMR $\left(\mathrm{CDCl}_{3}, 400 \mathrm{MHz}\right): 7.75(\mathrm{~d}, J=2.2 \mathrm{~Hz}, 1 \mathrm{H}), 7.53-7.46(\mathrm{~m}, 2 \mathrm{H}), 7.34(\mathrm{dd}, J=8.0,2.2 \mathrm{~Hz}, 1 \mathrm{H})$, $7.07-6.99(\mathrm{~m}, 4 \mathrm{H}), 6.73(\mathrm{dd}, J=3.6,0.9 \mathrm{~Hz}, 1 \mathrm{H}), 5.69(\mathrm{~s}, 1 \mathrm{H}), 3.60$ (qt, $J=9.0,6.9 \mathrm{~Hz}, 1 \mathrm{H}), 2.50$ (tq, $J$ 
$=7.2,2.5 \mathrm{~Hz}, 1 \mathrm{H}), 2.24(\mathrm{~s}, 3 \mathrm{H}), 1.79(\mathrm{t}, J=2.5 \mathrm{~Hz}, 3 \mathrm{H}) \mathrm{ppm}$.

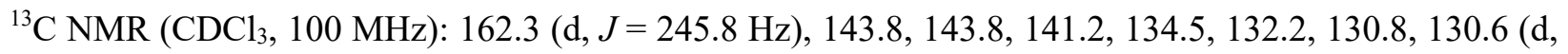
$J=3.3 \mathrm{~Hz}), 129.3,127.4(\mathrm{~d}, J=8.0 \mathrm{~Hz}), 126.9,122.3(\mathrm{~d}, J=1.2 \mathrm{~Hz}), 120.1,115.8(\mathrm{~d}, J=21.7 \mathrm{~Hz}), 77.0$, 76.4, 75.7, 67.9, 20.3, 18.8, 3.6 ppm.

${ }^{19} \mathrm{~F}$ NMR (377 MHz, $\left.\mathrm{CDCl}_{3}\right):-114.5 \mathrm{ppm}$.

HRMS Calculated for $\left[\mathrm{C}_{23} \mathrm{H}_{20} \mathrm{BrFOS}+\mathrm{Na}\right]^{+}$: 465.0295, Found: 465.0294 .

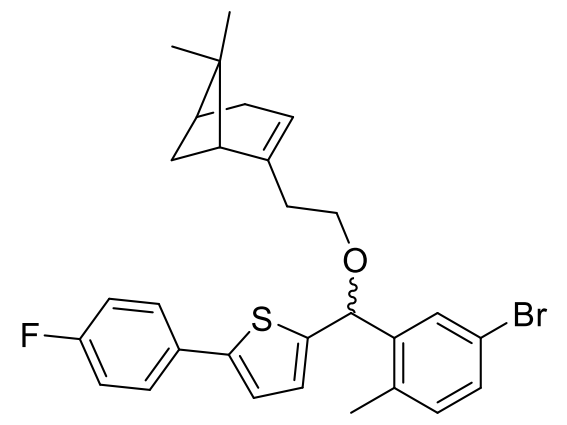

2-((5-bromo-2-methylphenyl)(2-((1R,5S)-6,6-dimethylbicyclo[3.1.1]hept-2-en-2-yl)ethoxy)methyl)-5-(4fluorophenyl)thiophene, $\mathbf{4 2}$.

Reaction run at $0.2 \mathrm{mmol}$ scale and $35.7 \mathrm{mg}(34 \%)$ of colorless liquid isolated.

${ }^{1} \mathrm{H} \mathrm{NMR}\left(\mathrm{CDCl}_{3}, 400 \mathrm{MHz}\right): 7.73(\mathrm{~d}, J=2.2 \mathrm{~Hz}, 1 \mathrm{H}), 7.53-7.46(\mathrm{~m}, 2 \mathrm{H}), 7.34(\mathrm{dd}, J=8.1,2.2 \mathrm{~Hz}, 1 \mathrm{H})$, $7.07-6.99(\mathrm{~m}, 4 \mathrm{H}), 6.71(\mathrm{dd}, J=3.6,0.8 \mathrm{~Hz}, 1 \mathrm{H}), 5.60(\mathrm{~d}, J=2.0 \mathrm{~Hz}, 1 \mathrm{H}), 5.27(\mathrm{ddq}, J=4.7,3.2,1.6 \mathrm{~Hz}$, $1 \mathrm{H}), 3.58-3.45(\mathrm{~m}, 2 \mathrm{H}), 2.42-2.14(\mathrm{~m}, 8 \mathrm{H}), 2.10-2.02(\mathrm{~m}, 2 \mathrm{H}), 1.26(\mathrm{~d}, J=3.7 \mathrm{~Hz}, 3 \mathrm{H}), 1.17(\mathrm{~d}, J=$ $8.5 \mathrm{~Hz}, 1 \mathrm{H}), 0.82(\mathrm{~d}, J=1.5 \mathrm{~Hz}, 3 \mathrm{H}) \mathrm{ppm}$.

${ }^{13} \mathrm{C} \mathrm{NMR}\left(\mathrm{CDCl}_{3}, 100 \mathrm{MHz}\right): 162.3(\mathrm{~d}, J=245.5 \mathrm{~Hz}), 144.9,144.3,143.6,141.7,134.4,132.2,130.7$, $130.6(\mathrm{~d}, J=3.4 \mathrm{~Hz}), 129.3,127.3(\mathrm{~d}, J=8.0 \mathrm{~Hz}), 126.6,122.3,120.1,118.1,115.8(\mathrm{~d}, J=21.6 \mathrm{~Hz}), 76.3$, 67.9, 46.0, 40.8, 38.0, 37.2, 31.7, 31.4, 26.3, 21.2, 18.8 ppm.

${ }^{19} \mathrm{~F}$ NMR (377 MHz, $\left.\mathrm{CDCl}_{3}\right)$ : $-114.6 \mathrm{ppm}$.

HRMS Calculated for $\left[\mathrm{C}_{29} \mathrm{H}_{30} \mathrm{BrFOS}+\mathrm{Na}\right]^{+}:$547.1077, Found: 547.1071.

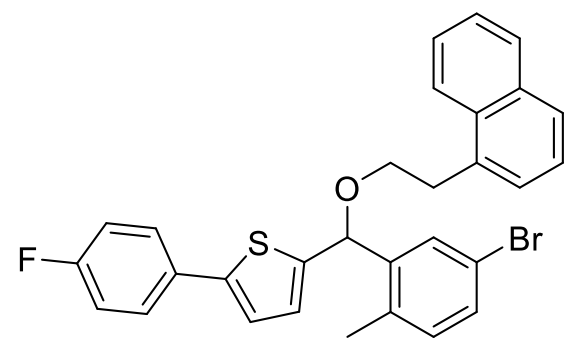

2-((5-bromo-2-methylphenyl)(2-(naphthalen-1-yl)ethoxy)methyl)-5-(4-fluorophenyl)thiophene, 43.

Reaction run at $0.2 \mathrm{mmol}$ scale and $95.7 \mathrm{mg}(90 \%)$ of colorless liquid isolated.

${ }^{1} \mathrm{H}$ NMR $\left(\mathrm{CDCl}_{3}, 400 \mathrm{MHz}\right): 8.02(\mathrm{~d}, J=8.6 \mathrm{~Hz}, 1 \mathrm{H}), 7.84(\mathrm{dd}, J=7.8,1.8 \mathrm{~Hz}, 1 \mathrm{H}), 7.75-7.70(\mathrm{~m}, 2 \mathrm{H})$, $7.53-7.43(\mathrm{~m}, 4 \mathrm{H}), 7.43-7.36(\mathrm{~m}, 2 \mathrm{H}), 7.32(\mathrm{dd}, J=8.1,2.2 \mathrm{~Hz}, 1 \mathrm{H}), 7.08-6.95(\mathrm{~m}, 4 \mathrm{H}), 6.67$ (dd, $J=$ $3.7,0.8 \mathrm{~Hz}, 1 \mathrm{H}), 5.58(\mathrm{~s}, 1 \mathrm{H}), 3.90-3.78(\mathrm{~m}, 2 \mathrm{H}), 3.46(\mathrm{t}, J=7.3 \mathrm{~Hz}, 2 \mathrm{H}), 2.14(\mathrm{~s}, 3 \mathrm{H}) \mathrm{ppm}$. 
${ }^{13} \mathrm{C} \mathrm{NMR}\left(\mathrm{CDCl}_{3}, 100 \mathrm{MHz}\right): 162.4(\mathrm{~d}, J=245.7 \mathrm{~Hz}), 144.0,143.7,141.5,134.7,134.4,133.9,132.2$, 132.1, 130.8, 130.6 (d, $J=3.4 \mathrm{~Hz}), 129.2,128.8,127.4$ (d, $J=8.0 \mathrm{~Hz}), 127.2,127.1,126.8,126.1,125.6$ (d, $J=1.5 \mathrm{~Hz}), 123.8,122.3,122.3,120.1,115.8(\mathrm{~d}, J=21.6 \mathrm{~Hz}), 76.5,69.5,33.6,18.7 \mathrm{ppm}$.

${ }^{19} \mathrm{~F}$ NMR (377 MHz, $\mathrm{CDCl}_{3}$ ): $-114.4 \mathrm{ppm}$.

HRMS Calculated for $\left[\mathrm{C}_{30} \mathrm{H}_{24} \mathrm{BrFOS}+\mathrm{Na}\right]^{+}: 553.0608$, Found: 553.0606.<smiles>Cc1ccc(Br)cc1C(OCCCOCc1ccccc1)c1ccc(-c2ccc(F)cc2)s1</smiles>

2-((3-(benzyloxy)propoxy)(5-bromo-2-methylphenyl)methyl)-5-(4-fluorophenyl)thiophene, 44.

Reaction run at $0.2 \mathrm{mmol}$ scale and $73.7 \mathrm{mg}(70 \%)$ of colorless liquid isolated.

${ }^{1} \mathrm{H} \mathrm{NMR}\left(\mathrm{CDCl}_{3}, 400 \mathrm{MHz}\right): 7.71(\mathrm{~d}, J=2.1 \mathrm{~Hz}, 1 \mathrm{H}), 7.51-7.45(\mathrm{~m}, 2 \mathrm{H}), 7.33(\mathrm{dd}, J=8.0,2.2 \mathrm{~Hz}, 1 \mathrm{H})$, $7.32-7.22(\mathrm{~m}, 5 \mathrm{H}), 7.06-6.99(\mathrm{~m}, 4 \mathrm{H}), 6.70(\mathrm{dd}, J=3.7,0.9 \mathrm{~Hz}, 1 \mathrm{H}), 5.60(\mathrm{~s}, 1 \mathrm{H}), 4.51(\mathrm{~d}, J=11.8 \mathrm{~Hz}$, $1 \mathrm{H}), 4.49(\mathrm{~d}, J=11.8 \mathrm{~Hz}, 1 \mathrm{H}), 3.69-3.55(\mathrm{~m}, 4 \mathrm{H}), 2.23(\mathrm{~s}, 3 \mathrm{H}), 1.96(\mathrm{p}, J=6.2 \mathrm{~Hz}, 2 \mathrm{H}) \mathrm{ppm}$.

${ }^{13} \mathrm{C} \mathrm{NMR}\left(\mathrm{CDCl}_{3}, 100 \mathrm{MHz}\right): 162.3(\mathrm{~d}, J=245.5 \mathrm{~Hz}), 144.3,143.6,141.6,138.5,134.5,132.2,130.8$, 130.6 (d, $J=3.4 \mathrm{~Hz}), 129.3,128.4,127.7,127.6,127.4$ (d, $J=8.0 \mathrm{~Hz}), 126.7,122.3$ (d, $J=1.2 \mathrm{~Hz}), 120.1$, $115.8(\mathrm{~d}, J=21.6 \mathrm{~Hz}), 76.5,73.1,67.2,66.3,30.2,18.8 \mathrm{ppm}$.

${ }^{19} \mathrm{~F}$ NMR (377 MHz, $\left.\mathrm{CDCl}_{3}\right)$ : $-114.5 \mathrm{ppm}$.

HRMS Calculated for $\left[\mathrm{C}_{28} \mathrm{H}_{26} \mathrm{BrFO}_{2} \mathrm{~S}+\mathrm{Na}\right]^{+}:$547.0713, Found: 547.0709.

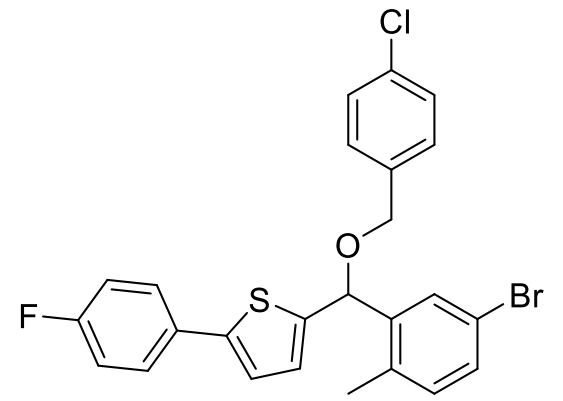

2-((5-bromo-2-methylphenyl)((4-chlorobenzyl)oxy)methyl)-5-(4-fluorophenyl)thiophene, 45.

Reaction run at $0.2 \mathrm{mmol}$ scale and $90.3 \mathrm{mg}(90 \%)$ of colorless liquid isolated.

${ }^{1} \mathrm{H}$ NMR $\left(\mathrm{CDCl}_{3}, 400 \mathrm{MHz}\right): 7.77(\mathrm{~d}, J=2.2 \mathrm{~Hz}, 1 \mathrm{H}), 7.54-7.46(\mathrm{~m}, 2 \mathrm{H}), 7.39-7.27(\mathrm{~m}, 5 \mathrm{H}), 7.07$ 6.99 (m, 4H), $6.72(\mathrm{dd}, J=3.8,0.9 \mathrm{~Hz}, 1 \mathrm{H}), 5.67$ (s, 1H), 4.57 (d, $J=12.1 \mathrm{~Hz}, 1 \mathrm{H}), 4.51$ (d, $J=12.1 \mathrm{~Hz}$, $1 \mathrm{H}), 2.18(\mathrm{~s}, 3 \mathrm{H}) \mathrm{ppm}$.

${ }^{13} \mathrm{C} \mathrm{NMR}\left(\mathrm{CDCl}_{3}, 100 \mathrm{MHz}\right): 162.4(\mathrm{~d}, J=245.8 \mathrm{~Hz}), 144.0,143.7,140.9,136.2,134.6,133.6,132.4$, $131.0,130.9,130.5(\mathrm{~d}, J=3.4 \mathrm{~Hz}), 129.5,129.4,129.2,128.7,127.4(\mathrm{~d}, J=8.0 \mathrm{~Hz}), 127.0,122.4(\mathrm{~d}, J=$ $1.2 \mathrm{~Hz}), 120.2,115.8(\mathrm{~d}, J=21.7 \mathrm{~Hz}), 75.2,69.9,18.8 \mathrm{ppm}$.

${ }^{19} \mathrm{~F}$ NMR (377 MHz, $\left.\mathrm{CDCl}_{3}\right)$ : $-114.3 \mathrm{ppm}$.

HRMS Calculated for $\left[\mathrm{C}_{25} \mathrm{H}_{19} \mathrm{BrClFOS}+\mathrm{Na}\right]^{+}:$522.9905, Found: 522.9899. 
<smiles>COc1ccc(COC(c2ccc(-c3ccc(F)cc3)s2)c2cc(Br)ccc2C)cc1</smiles>

2-((5-bromo-2-methylphenyl)((4-methoxybenzyl)oxy)methyl)-5-(4-fluorophenyl)thiophene, 46.

Reaction run at $0.2 \mathrm{mmol}$ scale and $72.6 \mathrm{mg}(73 \%)$ of yellow liquid isolated.

${ }^{1} \mathrm{H}$ NMR $\left(\mathrm{CDCl}_{3}, 400 \mathrm{MHz}\right): 7.78(\mathrm{~d}, J=2.2 \mathrm{~Hz}, 1 \mathrm{H}), 7.53-7.46(\mathrm{~m}, 2 \mathrm{H}), 7.35(\mathrm{dd}, J=8.1,2.2 \mathrm{~Hz}, 1 \mathrm{H})$, $7.29(\mathrm{~d}, J=8.6 \mathrm{~Hz}, 2 \mathrm{H}), 7.07-6.98(\mathrm{~m}, 4 \mathrm{H}), 6.69(\mathrm{dd}, J=3.6,0.9 \mathrm{~Hz}, 1 \mathrm{H}), 5.66(\mathrm{~s}, 1 \mathrm{H}), 4.56(\mathrm{~d}, J=11.6$ $\mathrm{Hz}, 1 \mathrm{H}), 4.46(\mathrm{~d}, J=11.6 \mathrm{~Hz}, 1 \mathrm{H}), 3.81(\mathrm{~s}, 3 \mathrm{H}), 2.17(\mathrm{~s}, 3 \mathrm{H}) \mathrm{ppm}$.

${ }^{13} \mathrm{C}$ NMR $\left(\mathrm{CDCl}_{3}, 100 \mathrm{MHz}\right): 162.3(\mathrm{~d}, J=245.7 \mathrm{~Hz}), 159.4,144.1,143.7,141.2,134.7,132.3,130.9$, $130.6(\mathrm{~d}, J=3.4 \mathrm{~Hz}), 129.7,129.6,129.6,127.4$ (d, $J=8.0 \mathrm{~Hz}), 126.8,122.3$ (d, $J=1.2 \mathrm{~Hz}), 120.1,115.8$ $(\mathrm{d}, J=21.6 \mathrm{~Hz}), 113.9,74.5,70.3,55.3,18.8 \mathrm{ppm}$.

${ }^{19} \mathrm{~F}$ NMR (377 MHz, $\mathrm{CDCl}_{3}$ ): $-114.5 \mathrm{ppm}$.

HRMS Calculated for $\left[\mathrm{C}_{26} \mathrm{H}_{22} \mathrm{BrFO}_{2} \mathrm{~S}+\mathrm{Na}\right]^{+}: 519.0400$, Found: 519.0397.<smiles>Cc1ccc(Br)cc1C(OCc1ccc([N+](=O)[O-])cc1)c1ccc(-c2ccc(F)cc2)s1</smiles>

2-((5-bromo-2-methylphenyl)((4-nitrobenzyl)oxy)methyl)-5-(4-fluorophenyl)thiophene, 47.

Reaction run at $0.2 \mathrm{mmol}$ scale and $81.9 \mathrm{mg}(79 \%)$ of yellow liquid isolated.

${ }^{1} \mathrm{H} \mathrm{NMR}\left(\mathrm{CDCl}_{3}, 400 \mathrm{MHz}\right): 8.23(\mathrm{~d}, J=8.7 \mathrm{~Hz}, 2 \mathrm{H}), 7.78(\mathrm{~d}, J=2.2 \mathrm{~Hz}, 1 \mathrm{H}), 7.55(\mathrm{~d}, J=8.6 \mathrm{~Hz}, 2 \mathrm{H})$, $7.54-7.48(\mathrm{~m}, 2 \mathrm{H}), 7.38(\mathrm{dd}, J=8.1,2.2 \mathrm{~Hz}, 1 \mathrm{H}), 7.09-7.01(\mathrm{~m}, 4 \mathrm{H}), 6.77(\mathrm{dd}, J=3.6,0.9 \mathrm{~Hz}, 1 \mathrm{H}), 5.73$ (s, 1H), $4.69(\mathrm{~d}, J=13.1 \mathrm{~Hz}, 1 \mathrm{H}), 4.67(\mathrm{~d}, J=13.1 \mathrm{~Hz}, 1 \mathrm{H}), 2.21(\mathrm{~s}, 3 \mathrm{H}) \mathrm{ppm}$.

${ }^{13} \mathrm{C} \mathrm{NMR}\left(\mathrm{CDCl}_{3}, 100 \mathrm{MHz}\right): 162.4(\mathrm{~d}, J=245.7 \mathrm{~Hz}), 147.5,145.3,144.2,143.1,140.6,134.6,132.5$, 131.2, $130.4(\mathrm{~d}, J=3.4 \mathrm{~Hz}), 129.2,127.9,127.4(\mathrm{~d}, J=8.0 \mathrm{~Hz}), 127.2,123.8,122.4(\mathrm{~d}, J=1.2 \mathrm{~Hz}), 120.2$, $115.9(\mathrm{~d}, J=21.7 \mathrm{~Hz}), 76.2,69.6,18.8 \mathrm{ppm}$.

${ }^{19} \mathrm{~F}$ NMR (377 MHz, $\left.\mathrm{CDCl}_{3}\right)$ : $-114.1 \mathrm{ppm}$.

HRMS Calculated for $\left[\mathrm{C}_{25} \mathrm{H}_{19} \mathrm{BrFNO}_{3} \mathrm{~S}+\mathrm{Na}\right]^{+}$: 534.0145, Found: 534.0144. 
<smiles>Cc1ccc(Br)cc1C(OCc1ccccc1Br)c1ccc(-c2ccc(F)cc2)s1</smiles>

2-((5-bromo-2-methylphenyl)((2-bromobenzyl)oxy)methyl)-5-(4-fluorophenyl)thiophene \}, 48.

Reaction run at $0.2 \mathrm{mmol}$ scale and $89.6 \mathrm{mg}(82 \%)$ of white solid isolated.

${ }^{1} \mathrm{H}$ NMR $\left(\mathrm{CDCl}_{3}, 400 \mathrm{MHz}\right): 7.81(\mathrm{~d}, J=2.2 \mathrm{~Hz}, 1 \mathrm{H}), 7.59-7.46(\mathrm{~m}, 4 \mathrm{H}), 7.39-7.31(\mathrm{~m}, 2 \mathrm{H}), 7.16(\mathrm{td}$, $J=7.7,1.7 \mathrm{~Hz}, 1 \mathrm{H}), 7.06-6.99(\mathrm{~m}, 4 \mathrm{H}), 6.75(\mathrm{dd}, J=3.8,0.9 \mathrm{~Hz}, 1 \mathrm{H}), 5.76(\mathrm{~s}, 1 \mathrm{H}), 4.642(\mathrm{~d}, J=13.3$ $\mathrm{Hz}, 1 \mathrm{H}), 4.639$ (d, $J=13.3 \mathrm{~Hz}, 1 \mathrm{H}), 2.22(\mathrm{~s}, 3 \mathrm{H}) \mathrm{ppm}$.

${ }^{13} \mathrm{C} \mathrm{NMR}\left(\mathrm{CDCl}_{3}, 100 \mathrm{MHz}\right): 162.4(\mathrm{~d}, J=245.8 \mathrm{~Hz}), 144.0,143.7,141.0,137.1,134.7,132.6,132.4$, 131.0, $130.6(\mathrm{~d}, J=3.4 \mathrm{~Hz}), 129.5,129.4,129.2,127.6,127.4(\mathrm{~d}, J=8.0 \mathrm{~Hz}), 127.0,122.9,122.4(\mathrm{~d}, J=$ $1.2 \mathrm{~Hz}), 120.2,115.8(\mathrm{~d}, J=21.6 \mathrm{~Hz}), 76.1,70.4,18.8 \mathrm{ppm}$.

${ }^{19} \mathrm{~F}$ NMR (377 MHz, $\left.\mathrm{CDCl}_{3}\right)$ : $-114.4 \mathrm{ppm}$.

HRMS Calculated for $\left[\mathrm{C}_{25} \mathrm{H}_{19} \mathrm{Br}_{2} \mathrm{FOS}+\mathrm{Na}\right]^{+}: 566.9400$, Found: 566.9396.<smiles>Cc1ccc(Br)cc1C(OCc1cccc(Br)c1)c1ccc(-c2ccc(F)cc2)s1</smiles>

2-((5-bromo-2-methylphenyl)((3-bromobenzyl)oxy)methyl)-5-(4-fluoro-phenyl)thiophene, 49.

Reaction run at $0.2 \mathrm{mmol}$ scale and $99.4 \mathrm{mg}(91 \%)$ of colorless liquid isolated.

${ }^{1} \mathrm{H} \mathrm{NMR}\left(\mathrm{CDCl}_{3}, 400 \mathrm{MHz}\right): 7.77(\mathrm{~d}, J=2.2 \mathrm{~Hz}, 1 \mathrm{H}), 7.54-7.48(\mathrm{~m}, 3 \mathrm{H}), 7.44(\mathrm{dt}, J=7.9,1.6 \mathrm{~Hz}, 1 \mathrm{H})$, $7.36(\mathrm{dd}, J=8.1,2.2 \mathrm{~Hz}, 1 \mathrm{H}), 7.30(\mathrm{dt}, J=7.7,1.4 \mathrm{~Hz}, 1 \mathrm{H}), 7.24(\mathrm{t}, J=7.7 \mathrm{~Hz}, 1 \mathrm{H}), 7.08-7.00$ (m, 4H), $6.73(\mathrm{dd}, J=3.7,0.9 \mathrm{~Hz}, 1 \mathrm{H}), 5.68(\mathrm{~s}, 1 \mathrm{H}), 4.57(\mathrm{~d}, J=12.2 \mathrm{~Hz}, 1 \mathrm{H}), 4.51(\mathrm{~d}, J=12.2 \mathrm{~Hz}, 1 \mathrm{H}), 2.19$ (s, 3H) $\mathrm{ppm}$.

${ }^{13} \mathrm{C} \mathrm{NMR}\left(\mathrm{CDCl}_{3}, 100 \mathrm{MHz}\right): 162.4(\mathrm{~d}, J=245.9 \mathrm{~Hz}), 144.0,143.5,140.8,140.0,134.6,132.4,131.0$, 130.9, 130.8, 130.5 (d, $J=3.4 \mathrm{~Hz}), 130.1,129.4,127.4$ (d, $J=8.0 \mathrm{~Hz}), 127.0,126.3,122.6,122.4$ (d, $J=$ $1.2 \mathrm{~Hz}), 120.2,115.8(\mathrm{~d}, J=21.7 \mathrm{~Hz}), 75.5,69.9,18.8 \mathrm{ppm}$.

${ }^{19} \mathrm{~F}$ NMR (377 MHz, $\left.\mathrm{CDCl}_{3}\right)$ : $-114.4 \mathrm{ppm}$.

HRMS Calculated for $\left[\mathrm{C}_{25} \mathrm{H}_{19} \mathrm{Br}_{2} \mathrm{FNOS}+\mathrm{Na}\right]^{+}:$566.9400, Found: 566.9399. 
<smiles>CCOC(c1ccc(-c2ccc(F)cc2)s1)c1cc(Br)ccc1C</smiles>

(((5-bromo-2-methylphenyl)(5-(4-fluorophenyl)thiophen-2-yl)methoxy)methyl)trimethylsilane, $\mathbf{5 0 .}$

Reaction run at $0.2 \mathrm{mmol}$ scale and $76.9 \mathrm{mg}(83 \%)$ of colorless liquid isolated.

${ }^{1} \mathrm{H}$ NMR $\left(\mathrm{CDCl}_{3}, 400 \mathrm{MHz}\right): 7.63(\mathrm{~d}, J=2.1 \mathrm{~Hz}, 1 \mathrm{H}), 7.55-7.48(\mathrm{~m}, 2 \mathrm{H}), 7.34(\mathrm{dd}, J=8.1,2.2 \mathrm{~Hz}, 1 \mathrm{H})$, $7.08-6.99(\mathrm{~m}, 4 \mathrm{H}), 6.66(\mathrm{dd}, J=3.6,1.0 \mathrm{~Hz}, 1 \mathrm{H}), 5.45(\mathrm{~s}, 1 \mathrm{H}), 3.17(\mathrm{~d}, J=12.4 \mathrm{~Hz}, 1 \mathrm{H}), 3.10(\mathrm{~d}, J=12.4$ $\mathrm{Hz}, 1 \mathrm{H}), 2.24$ (s, 3H), 0.10 (s, 9H) ppm.

${ }^{13} \mathrm{C} \mathrm{NMR}\left(\mathrm{CDCl}_{3}, 100 \mathrm{MHz}\right): 162.2(\mathrm{~d}, J=245.5 \mathrm{~Hz}), 144.8,143.4,141.7,134.9,132.2,130.7(\mathrm{~d}, J=3.3$ $\mathrm{Hz}), 130.6,129.7,127.4$ (d, $J=8.0 \mathrm{~Hz}), 126.3,122.2$ (d, $J=1.2 \mathrm{~Hz}), 119.9,115.7$ (d, $J=21.6 \mathrm{~Hz}), 80.4$, 63.0, 18.7, $-3.0 \mathrm{ppm}$.

${ }^{19} \mathrm{~F}$ NMR (377 MHz, $\left.\mathrm{CDCl}_{3}\right)$ : $-114.7 \mathrm{ppm}$.

HRMS Calculated for $\left[\mathrm{C}_{22} \mathrm{H}_{24} \mathrm{BrFOSSi}+\mathrm{Na}\right]^{+}:$485.0377, Found: 485.0377.<smiles>Cc1ccc(Br)cc1C(OCC1CC1)c1ccc(-c2ccc(F)cc2)s1</smiles>

2-((5-bromo-2-methylphenyl)(cyclopropylmethoxy)methyl)-5-(4-fluoro-phenyl)thiophene, 51.

Reaction run at $0.2 \mathrm{mmol}$ scale and $75.1 \mathrm{mg}(87 \%)$ of colorless liquid isolated.

${ }^{1} \mathrm{H} \mathrm{NMR}\left(\mathrm{CDCl}_{3}, 400 \mathrm{MHz}\right): 7.76(\mathrm{~d}, J=2.2 \mathrm{~Hz}, 1 \mathrm{H}), 7.55-7.48(\mathrm{~m}, 2 \mathrm{H}), 7.35(\mathrm{dd}, J=8.1,2.2 \mathrm{~Hz}, 1 \mathrm{H})$, $7.08-7.00(\mathrm{~m}, 4 \mathrm{H}), 6.74(\mathrm{dd}, J=3.7,0.8 \mathrm{~Hz}, 1 \mathrm{H}), 5.71(\mathrm{~s}, 1 \mathrm{H}), 3.42(\mathrm{dd}, J=10.1,6.8 \mathrm{~Hz}, 1 \mathrm{H}), 3.34(\mathrm{dd}$, $J=10.1,6.9 \mathrm{~Hz}, 1 \mathrm{H}), 2.27$ (s, 3H), 1.15 (dddd, $J=13.2,6.8,5.0,2.6 \mathrm{~Hz}, 1 \mathrm{H}), 0.65-0.51$ (m, 2H) , $0.30-$ $0.17(\mathrm{~m}, 2 \mathrm{H}) \mathrm{ppm}$.

${ }^{13} \mathrm{C} \mathrm{NMR}\left(\mathrm{CDCl}_{3}, 100 \mathrm{MHz}\right): 162.3(\mathrm{~d}, J=245.6 \mathrm{~Hz}), 144.2,143.6,141.5,134.6,132.2,130.7,130.6(\mathrm{~d}$, $J=3.3 \mathrm{~Hz}), 129.4,127.4$ (d, $J=8.0 \mathrm{~Hz}), 126.7,122.3$ (d, $J=1.2 \mathrm{~Hz}), 120.1,115.8$ (d, $J=21.6 \mathrm{~Hz}), 75.7$, $73.9,18.8,10.7,3.25,3.24 \mathrm{ppm}$.

${ }^{19} \mathrm{~F}$ NMR (377 MHz, $\left.\mathrm{CDCl}_{3}\right)$ : $-114.6 \mathrm{ppm}$.

HRMS Calculated for $\left[\mathrm{C}_{22} \mathrm{H}_{20} \mathrm{BrFOS}+\mathrm{Na}\right]^{+}$: 453.0295, Found: 453.0288 .<smiles>Cc1ccc(Br)cc1C(OCC1CN(C(=O)OC(C)(C)C)C1)c1ccc(-c2ccc(F)cc2)s1</smiles> 
tert-butyl 3-(((5-bromo-2-methylphenyl)(5-(4-fluorophenyl)thiophen-2-yl)methoxy)methyl)azetidine -1-carboxylate, $\mathbf{5 2}$.

Reaction run at $0.2 \mathrm{mmol}$ scale and $78.7 \mathrm{mg}(72 \%)$ of yellow liquid isolated.

${ }^{1} \mathrm{H}$ NMR $\left(\mathrm{CDCl}_{3}, 400 \mathrm{MHz}\right): 7.67(\mathrm{~d}, J=2.1 \mathrm{~Hz}, 1 \mathrm{H}), 7.54-7.47(\mathrm{~m}, 2 \mathrm{H}), 7.36(\mathrm{dd}, J=8.1,2.2 \mathrm{~Hz}, 1 \mathrm{H})$, $7.08-7.01(\mathrm{~m}, 4 \mathrm{H}), 6.73(\mathrm{dd}, J=3.7,0.8 \mathrm{~Hz}, 1 \mathrm{H}), 5.62(\mathrm{~s}, 1 \mathrm{H}), 4.02(\mathrm{td}, J=8.5,2.1 \mathrm{~Hz}, 2 \mathrm{H}), 3.75-3.58$ (m, 4H), $2.89-2.77(\mathrm{~m}, 1 \mathrm{H}), 2.24(\mathrm{~s}, 3 \mathrm{H}), 1.43(\mathrm{~s}, 9 \mathrm{H}) \mathrm{ppm}$.

${ }^{13} \mathrm{C} \mathrm{NMR}\left(\mathrm{CDCl}_{3}, 100 \mathrm{MHz}\right): 162.3(\mathrm{~d}, J=197.0 \mathrm{~Hz}), 156.4,143.9,143.6,141.1,134.5,132.3,132.2$, $130.4(\mathrm{~d}, J=3.0 \mathrm{~Hz}), 129.2,127.4(\mathrm{~d}, J=12.0 \mathrm{~Hz}), 126.8,122.3$ (d, $J=2.0 \mathrm{~Hz}), 120.1,115.8$ (d, $J=17.0$ $\mathrm{Hz}), 79.4,77.2,76.9,71.2,64.6,64.8,28.4,18.8 \mathrm{ppm}$.

${ }^{19} \mathrm{~F}$ NMR (377 MHz, $\left.\mathrm{CDCl}_{3}\right)$ : $-114.4 \mathrm{ppm}$.

HRMS Calculated for $\left[\mathrm{C}_{27} \mathrm{H}_{29} \mathrm{BrFO}_{3} \mathrm{~S}+\mathrm{Na}\right]^{+}: 568.0928$, Found: 568.0921.

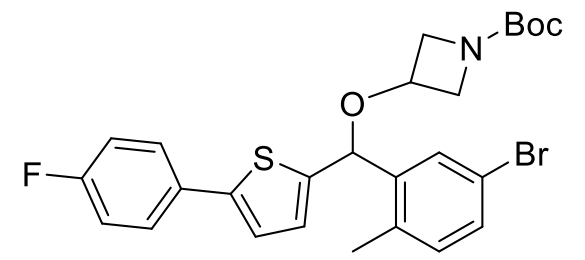

tert-butyl 3-((5-bromo-2-methylphenyl)(5-(4-fluorophenyl)thiophen-2-yl)methoxy)azetidine-1-carboxylate, 53.

Reaction run at $0.2 \mathrm{mmol}$ scale and $91.6 \mathrm{mg}(86 \%)$ of colorless liquid isolated.

${ }^{1} \mathrm{H}$ NMR $\left(\mathrm{CDCl}_{3}, 400 \mathrm{MHz}\right): 7.76(\mathrm{~d}, J=2.1 \mathrm{~Hz}, 1 \mathrm{H}), 7.53-7.46(\mathrm{~m}, 2 \mathrm{H}), 7.36(\mathrm{dd}, J=8.1,2.2 \mathrm{~Hz}, 1 \mathrm{H})$, $7.08-7.00(\mathrm{~m}, 4 \mathrm{H}), 6.78(\mathrm{dd}, J=3.7,0.8 \mathrm{~Hz}, 1 \mathrm{H}), 5.59$ (s, 1H), 4.37 (tt, $J=6.6,4.5 \mathrm{~Hz}, 1 \mathrm{H}), 4.04$ (dddd, $J=14.3,9.4,6.6,1.0 \mathrm{~Hz}, 2 \mathrm{H}), 3.92(\mathrm{ddd}, J=14.3,9.3,4.6 \mathrm{~Hz}, 2 \mathrm{H}), 2.20$ (s, 3H), 1.43 (s, 9H) ppm.

${ }^{13} \mathrm{C} \mathrm{NMR}\left(\mathrm{CDCl}_{3}, 100 \mathrm{MHz}\right): 162.4(\mathrm{~d}, J=246.1 \mathrm{~Hz}), 156.3,144.5,142.8,140.7,134.2,132.3,131.1$, $130.3(\mathrm{~d}, J=3.5 \mathrm{~Hz}), 129.1,127.4(\mathrm{~d}, J=8.0 \mathrm{~Hz}), 127.3,122.4(\mathrm{~d}, J=1.2 \mathrm{~Hz}), 120.1,115.9(\mathrm{~d}, J=21.7$ $\mathrm{Hz}), 79.7,75.0,66.4,57.2-56.3(\mathrm{~m}), 28.4,18.8 \mathrm{ppm}$.

${ }^{19} \mathrm{~F}$ NMR (377 MHz, $\left.\mathrm{CDCl}_{3}\right)$ : $-114.2 \mathrm{ppm}$.

HRMS Calculated for $\left[\mathrm{C}_{26} \mathrm{H}_{27} \mathrm{BrFO}_{3} \mathrm{~S}+\mathrm{Na}\right]^{+}$: 554.0771, Found: 554.0767.

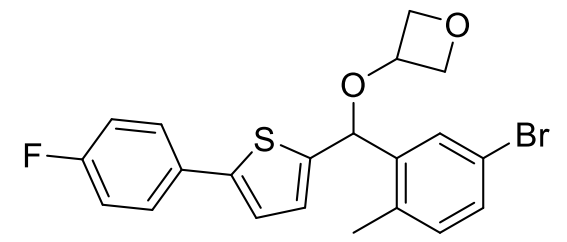

3-((5-bromo-2-methylphenyl)(5-(4-fluorophenyl)thiophen-2-yl)methoxy)oxetane, 54.

Reaction run at $0.2 \mathrm{mmol}$ scale and $39.9 \mathrm{mg}(46 \%)$ of colorless liquid isolated.

${ }^{1} \mathrm{H} \mathrm{NMR}\left(\mathrm{CDCl}_{3}, 400 \mathrm{MHz}\right): 7.78(\mathrm{~d}, J=2.1 \mathrm{~Hz}, 1 \mathrm{H}), 7.53-7.46(\mathrm{~m}, 2 \mathrm{H}), 7.36(\mathrm{dd}, J=8.1,2.2 \mathrm{~Hz}, 1 \mathrm{H})$, $7.08-6.99(\mathrm{~m}, 4 \mathrm{H}), 6.77(\mathrm{dd}, J=3.6,0.8 \mathrm{~Hz}, 1 \mathrm{H}), 5.58(\mathrm{~s}, 1 \mathrm{H}), 4.76-4.62(\mathrm{~m}, 5 \mathrm{H}), 2.20(\mathrm{~s}, 3 \mathrm{H}) \mathrm{ppm}$.

${ }^{13} \mathrm{C}$ NMR $\left(\mathrm{CDCl}_{3}, 100 \mathrm{MHz}\right): 162.4(\mathrm{~d}, J=246.2 \mathrm{~Hz}), 144.4,143.0,140.8,134.1,132.3,131.1,130.3(\mathrm{~d}$, $J=3.4 \mathrm{~Hz}), 129.1,127.4$ (d, $J=8.0 \mathrm{~Hz}), 127.3,122.4$ (d, $J=1.2 \mathrm{~Hz}), 120.1,115.9$ (d, $J=21.8 \mathrm{~Hz}), 79.1$, 
75.3, 71.2, $18.8 \mathrm{ppm}$.

${ }^{19} \mathrm{~F}$ NMR (377 MHz, $\left.\mathrm{CDCl}_{3}\right):-114.1 \mathrm{ppm}$.

HRMS Calculated for $\left[\mathrm{C}_{21} \mathrm{H}_{18} \mathrm{BrFO}_{2} \mathrm{~S}+\mathrm{Na}\right]^{+}: 455.0087$, Found: 455.0083.

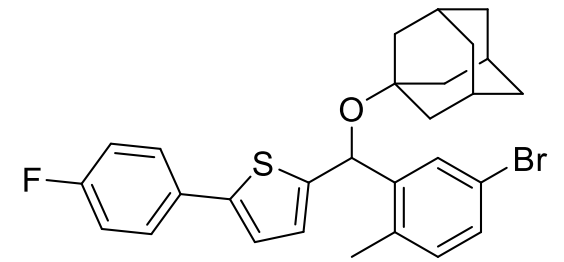

2-((((3S,5S,7S)-adamantan-1-yl)oxy)(5-bromo-2-methylphenyl)methyl)-5-(4-fluorophenyl)thiophene, 55. Reaction run at $0.2 \mathrm{mmol}$ scale and $75.7 \mathrm{mg}(74 \%)$ of white solid isolated.

${ }^{1} \mathrm{H} \mathrm{NMR}\left(\mathrm{CDCl}_{3}, 400 \mathrm{MHz}\right): 7.83(\mathrm{~d}, J=2.2 \mathrm{~Hz}, 1 \mathrm{H}), 7.53-7.46(\mathrm{~m}, 2 \mathrm{H}), 7.32(\mathrm{dd}, J=8.1,2.2 \mathrm{~Hz}, 1 \mathrm{H})$, $7.07-6.98(\mathrm{~m}, 3 \mathrm{H}), 6.95(\mathrm{~d}, J=3.6 \mathrm{~Hz}, 1 \mathrm{H}), 6.42(\mathrm{dd}, J=3.7,1.0 \mathrm{~Hz}, 1 \mathrm{H}), 5.96(\mathrm{~s}, 1 \mathrm{H}), 2.27(\mathrm{~s}, 3 \mathrm{H}), 2.14$ $(\mathrm{q}, J=3.2 \mathrm{~Hz}, 3 \mathrm{H}), 1.83(\mathrm{~d}, J=11.3 \mathrm{~Hz}, 3 \mathrm{H}), 1.76(\mathrm{~d}, J=11.3 \mathrm{~Hz}, 3 \mathrm{H}), 1.63(\mathrm{~d}, J=13.9 \mathrm{~Hz}, 3 \mathrm{H}), 1.60(\mathrm{~d}$, $J=13.9 \mathrm{~Hz}, 3 \mathrm{H}) \mathrm{ppm}$.

${ }^{13} \mathrm{C} \mathrm{NMR}\left(\mathrm{CDCl}_{3}, 100 \mathrm{MHz}\right): 162.2(\mathrm{~d}, J=245.4 \mathrm{~Hz}), 147.3,144.5,143.1,133.2,131.9,130.4(\mathrm{~d}, J=3.4$ $\mathrm{Hz}), 130.3,130.2,127.3$ (d, $J=8.0 \mathrm{~Hz}), 125.8,122.4$ (d, $J=0.9 \mathrm{~Hz}), 119.8,115.7$ (d, $J=21.6 \mathrm{~Hz}), 75.0$, 66.8, 42.6, 36.3, 30.7, $18.9 \mathrm{ppm}$.

${ }^{19} \mathrm{~F}$ NMR (377 MHz, $\left.\mathrm{CDCl}_{3}\right)$ : $-114.9 \mathrm{ppm}$.

HRMS Calculated for $\left[\mathrm{C}_{28} \mathrm{H}_{28} \mathrm{BrFNOS}+\mathrm{Na}\right]^{+}:$533.0921, Found: 533.0916.

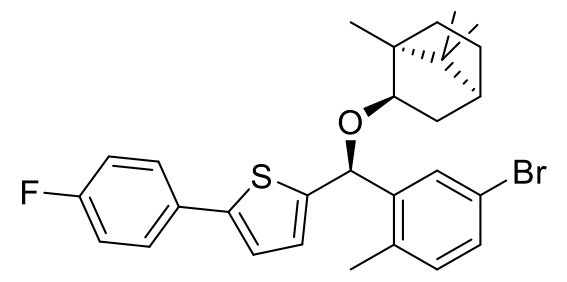

2-((S)-(5-bromo-2-methylphenyl)(((1S,2R,4S)-1,7,7-trimethylbicyclo[2.2.1]heptan-2-yl)oxy)methyl)-5-(4fluorophenyl)thiophene, 56a.

Reaction run at $0.2 \mathrm{mmol}$ scale and $49.3 \mathrm{mg}(48 \%)$ of white solid isolated.

${ }^{1} \mathrm{H}$ NMR $\left(\mathrm{CDCl}_{3}, 400 \mathrm{MHz}\right): 7.69(\mathrm{~d}, J=2.2 \mathrm{~Hz}, 1 \mathrm{H}), 7.55-7.47(\mathrm{~m}, 2 \mathrm{H}), 7.35(\mathrm{dd}, J=8.0,2.2 \mathrm{~Hz}, 1 \mathrm{H})$, $7.08-7.01(\mathrm{~m}, 3 \mathrm{H}), 6.99(\mathrm{~d}, J=3.6 \mathrm{~Hz}, 1 \mathrm{H}), 6.50(\mathrm{dd}, J=3.7,1.1 \mathrm{~Hz}, 1 \mathrm{H}), 5.62(\mathrm{~d}, J=1.1 \mathrm{~Hz}, 1 \mathrm{H}), 3.64$ (ddd, $J=9.1,3.3,1.8 \mathrm{~Hz}, 1 \mathrm{H}), 2.29-2.20(\mathrm{~m}, 4 \mathrm{H}), 2.17-2.07(\mathrm{~m}, 1 \mathrm{H}), 1.78(\mathrm{tq}, J=11.8,4.1 \mathrm{~Hz}, 1 \mathrm{H})$, $1.70(\mathrm{t}, J=4.6 \mathrm{~Hz}, 1 \mathrm{H}), 1.38(\mathrm{ddd}, J=11.9,9.4,4.4 \mathrm{~Hz}, 1 \mathrm{H}), 1.34-1.25(\mathrm{~m}, 1 \mathrm{H}), 1.22$ (dd, $J=12.8,3.2$ $\mathrm{Hz}, 1 \mathrm{H}), 0.86(\mathrm{~s}, 3 \mathrm{H}), 0.85$ (s, 3H), 0.76 (s, 3H) ppm.

${ }^{13} \mathrm{C} \mathrm{NMR}\left(\mathrm{CDCl}_{3}, 100 \mathrm{MHz}\right): 162.2(\mathrm{~d}, J=245.3 \mathrm{~Hz}), 146.2,143.1,141.5,134.9,132.2,130.8(\mathrm{~d}, J=3.4$ Hz), 130.7, 130.2, 127.4 (d, $J=7.9 \mathrm{~Hz}), 125.5,122.3$ (d, $J=1.2 \mathrm{~Hz}), 119.9,115.7$ (d, $J=21.7 \mathrm{~Hz}), 82.5$, 74.6, 49.4, 47.9, 45.2, 36.0, 28.3, 26.9, 19.8, 19.0, 18.8, $13.7 \mathrm{ppm}$.

${ }^{19} \mathrm{~F}$ NMR $\left(377 \mathrm{MHz}, \mathrm{CDCl}_{3}\right)$ : $-114.8 \mathrm{ppm}$.

HRMS Calculated for $\left[\mathrm{C}_{28} \mathrm{H}_{30} \mathrm{BrFNOS}+\mathrm{Na}\right]^{+}: 535.1077$, Found: 535.1081. 
<smiles>Cc1ccc(Br)cc1[C@H](O[C@H]1CC2CCC1(C)C2)c1ccc(-c2ccc(F)cc2)s1</smiles>

2-((R)-(5-bromo-2-methylphenyl)(((1S,2R,4S)-1,7,7-trimethylbicyclo[2.2.1]heptan-2-yl)oxy)methyl) -5-(4-fluorophenyl)thiophene, 56b.

Reaction run at $0.2 \mathrm{mmol}$ scale and $38.0 \mathrm{mg}(37 \%)$ of white solid isolated.

${ }^{1} \mathrm{H}$ NMR $\left(\mathrm{CDCl}_{3}, 400 \mathrm{MHz}\right): 7.76(\mathrm{~d}, J=2.2 \mathrm{~Hz}, 1 \mathrm{H}), 7.54-7.48(\mathrm{~m}, 2 \mathrm{H}), 7.33(\mathrm{dd}, J=8.1,2.2 \mathrm{~Hz}, 1 \mathrm{H})$, $7.07-6.98(\mathrm{~m}, 4 \mathrm{H}), 6.64(\mathrm{dd}, J=3.7,0.9 \mathrm{~Hz}, 1 \mathrm{H}), 5.61(\mathrm{~s}, 1 \mathrm{H}), 3.79(\mathrm{ddd}, J=9.5,3.5,1.8 \mathrm{~Hz}, 1 \mathrm{H}), 2.23$ $(\mathrm{s}, 3 \mathrm{H}), 2.22-2.16(\mathrm{~m}, 1 \mathrm{H}), 2.02(\mathrm{ddd}, J=13.1,9.3,4.1 \mathrm{~Hz}, 1 \mathrm{H}), 1.71(\mathrm{tt}, J=12.2,4.1 \mathrm{~Hz}, 1 \mathrm{H}), 1.61(\mathrm{t}, J$ $=4.6 \mathrm{~Hz}, 1 \mathrm{H}), 1.36-1.19(\mathrm{~m}, 1 \mathrm{H}), 1.03(\mathrm{dd}, J=13.1,3.4 \mathrm{~Hz}, 1 \mathrm{H}), 0.95(\mathrm{~s}, 3 \mathrm{H}), 0.85(\mathrm{~s}, 3 \mathrm{H}), 0.79(\mathrm{~s}, 3 \mathrm{H})$ ppm.

${ }^{13} \mathrm{C} \mathrm{NMR}\left(\mathrm{CDCl}_{3}, 100 \mathrm{MHz}\right): 162.3(\mathrm{~d}, J=196.5 \mathrm{~Hz}), 145.2,143.4,142.8,134.2,132.1,130.7(\mathrm{~d}, J=2.7$ $\mathrm{Hz}), 130.5,129.8,127.3$ (d, $J=6.4 \mathrm{~Hz}), 126.2$ (d, $J=1.4 \mathrm{~Hz}), 122.1$ (d, $J=2.4 \mathrm{~Hz}), 119.8,115.7$ (d, $J=$ $17.3 \mathrm{~Hz}), 83.6,76.0,49.7,47.7,45.1,35.9,28.2,27.1,19.8,19.0,18.9,14.1 \mathrm{ppm}$.

${ }^{19} \mathrm{~F}$ NMR (377 MHz, $\left.\mathrm{CDCl}_{3}\right)$ : $-114.8 \mathrm{ppm}$.

HRMS Calculated for $\left[\mathrm{C}_{28} \mathrm{H}_{30} \mathrm{BrFNOS}+\mathrm{Na}\right]^{+}:$535.1077, Found: 535.1077.

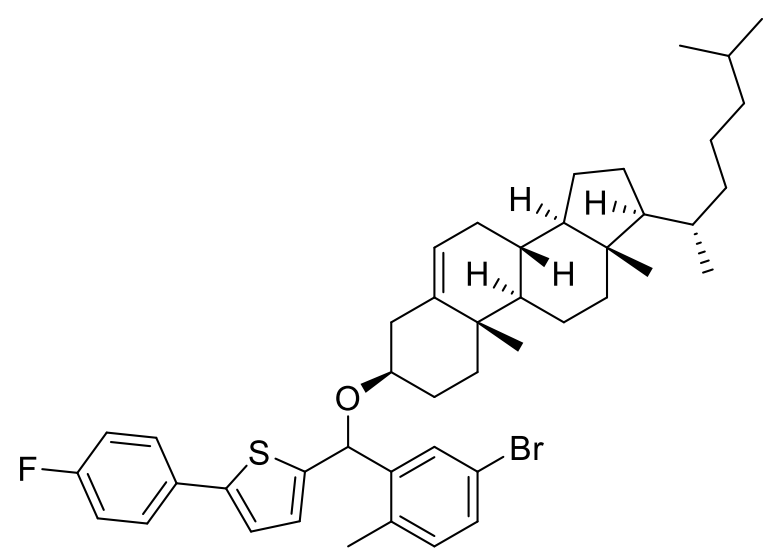

2-((5-bromo-2-methylphenyl) $(((3 S, 8 S, 9 S, 10 R, 13 R, 14 S, 17 R)-10,13$-dimethyl-17-((R)-6-methyl-heptan-2yl)-2,3,4,7,8,9,10,11,12,13,14,15,16,17-tetradecahydro-1 $H$-cyclopenta[ $a]$ phenanthren-3-yl)oxy)methyl)5-(4-fluorophenyl)thiophene, 57.

Reaction run at $0.2 \mathrm{mmol}$ scale and $58.2 \mathrm{mg}(39 \%)$ of pale yellow liquid isolated.

${ }^{1} \mathrm{H} \mathrm{NMR}\left(\mathrm{CDCl}_{3}, 400 \mathrm{MHz}\right): 7.77(\mathrm{~d}, J=2.2 \mathrm{~Hz}, 1 \mathrm{H}), 7.53-7.46(\mathrm{~m}, 2 \mathrm{H}), 7.33(\mathrm{dd}, J=8.1,2.2 \mathrm{~Hz}, 1 \mathrm{H})$, $7.07-6.98(\mathrm{~m}, 4 \mathrm{H}), 6.66(\mathrm{dd}, J=4.6,0.8 \mathrm{~Hz}, 1 \mathrm{H}), 5.81(\mathrm{~s}, 1 \mathrm{H}), 5.33(\mathrm{dd}, J=12.1,5.0 \mathrm{~Hz}, 1 \mathrm{H}), 3.31(\mathrm{td}$, $J=10.2,5.0 \mathrm{~Hz}, 1 \mathrm{H}), 2.50-2.30(\mathrm{~m}, 2 \mathrm{H}), 2.25(\mathrm{~s}, 3 \mathrm{H}), 2.05-1.75(\mathrm{~m}, 4 \mathrm{H}), 1.70-0.93(\mathrm{~m}, 22 \mathrm{H}), 1.02(\mathrm{~s}$, $3 \mathrm{H}), 0.91(\mathrm{~d}, J=6.5 \mathrm{~Hz}, 3 \mathrm{H}), 0.862(\mathrm{~d}, J=6.6 \mathrm{~Hz}, 3 \mathrm{H}), 0.857$ (d, $J=6.6 \mathrm{~Hz}, 3 \mathrm{H}), 0.67$ (s, 3H) ppm. 
${ }^{13} \mathrm{C} \mathrm{NMR}\left(\mathrm{CDCl}_{3}, 100 \mathrm{MHz}\right): 163.3(\mathrm{~d}, J=245.4 \mathrm{~Hz}), 145.0,143.5,142.2,140.7,134.3,132.2,130.6(\mathrm{~d}$, $J=3.2 \mathrm{~Hz}), 129.6,127.4$ (d, $J=7.9 \mathrm{~Hz}), 126.4,122.3,121.88,121.86,120.1,115.7$ (d, $J=21.6 \mathrm{~Hz}), 73.1$, 56.8, 56.1, 50.2, 42.3, 39.8, 39.5, 39.4, 39.2, 37.2, 36.9, 36.2, 35. 8, 31.9, 28.8, 28.5, 28.2, 28.0, 24.3, 23.8, 22.8, 22.6, 21.1, 19.4, 18.9, 18.7, $11.9 \mathrm{ppm}$.

${ }^{19} \mathrm{~F}$ NMR $\left(377 \mathrm{MHz}, \mathrm{CDCl}_{3}\right)$ : $-114.6 \mathrm{ppm}$.

HRMS Calculated for $\left[\mathrm{C}_{45} \mathrm{H}_{58} \mathrm{BrFOS}-\mathrm{OC}_{27} \mathrm{H}_{45}\right]^{+}$(ASAP-MS): 358.9900, Found: 358.9895.

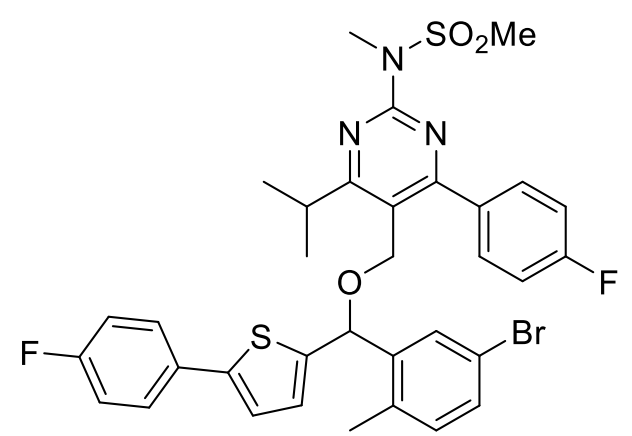

$N$-(5-(((5-bromo-2-methylphenyl)(5-(4-fluorophenyl)thiophen-2-yl)methoxy)methyl)-4-(4-fluorophenyl)6-isopropylpyrimidin-2-yl)- $N$-methylmethanesulfonamide, 58.

Reaction run at $0.2 \mathrm{mmol}$ scale and $133 \mathrm{mg}(93 \%)$ of pale yellow liquid isolated.

${ }^{1} \mathrm{H} \mathrm{NMR}\left(\mathrm{CDCl}_{3}, 400 \mathrm{MHz}\right): 7.83(\mathrm{~d}, J=2.1 \mathrm{~Hz}, 1 \mathrm{H}), 7.77-7.70(\mathrm{~m}, 2 \mathrm{H}), 7.54-7.47$ (m, 2H), 7.39 (dd, $J=8.1,2.2 \mathrm{~Hz}, 1 \mathrm{H}), 7.11-7.02(\mathrm{~m}, 6 \mathrm{H}), 6.74(\mathrm{dd}, J=3.6,0.8 \mathrm{~Hz}, 1 \mathrm{H}), 5.68(\mathrm{~s}, 1 \mathrm{H}), 4.46(\mathrm{~d}, J=10.2 \mathrm{~Hz}$, $1 \mathrm{H}), 4.41(\mathrm{~d}, J=10.2 \mathrm{~Hz}, 1 \mathrm{H}), 3.58(\mathrm{~s}, 3 \mathrm{H}), 3.51$ (s, 3H), 3.34 (sept., $J=6.6 \mathrm{~Hz}, 1 \mathrm{H}), 2.22$ (s, 3H), 1.34 (d, $J=6.6 \mathrm{~Hz}, 3 \mathrm{H}), 1.31(\mathrm{~d}, J=6.6 \mathrm{~Hz}, 3 \mathrm{H}) \mathrm{ppm}$.

${ }^{13} \mathrm{C}$ NMR $\left(\mathrm{CDCl}_{3}, 100 \mathrm{MHz}\right): 178.3,166.6,163.7(\mathrm{~d}, J=248.4 \mathrm{~Hz}), 162.5(\mathrm{~d}, J=246.1 \mathrm{~Hz}), 158.2,144.3$, 143.1, 140.8, 134.3, 134.0 (d, $J=3.2 \mathrm{~Hz}), 132.4,131.4$ (d, $J=8.4 \mathrm{~Hz}), 131.2,130.3$ (d, $J=3.4 \mathrm{~Hz}), 129.2$, $127.44(\mathrm{~d}, J=8.0 \mathrm{~Hz}), 127.37,122.5(\mathrm{~d}, J=1.2 \mathrm{~Hz}), 120.1,118.3,115.9(\mathrm{~d}, J=21.7 \mathrm{~Hz}), 115.4(\mathrm{~d}, J=$ $21.5 \mathrm{~Hz}), 76.6,64.6,42.4,33.1,31.7,22.4,22.2,18.9 \mathrm{ppm}$.

${ }^{19} \mathrm{~F} \mathrm{NMR}\left(377 \mathrm{MHz}, \mathrm{CDCl}_{3}\right.$ ): $-111.1,-114.0 \mathrm{ppm}$.

HRMS Calculated for $\left[\mathrm{C}_{34} \mathrm{H}_{32} \mathrm{BrF}_{2} \mathrm{O}_{3} \mathrm{~S}_{2}+\mathrm{Na}\right]^{+}:$712.1109, Found: 712.1112.<smiles>CCc1ccc2nc(NC(C)=O)sc2c1</smiles>

$\mathrm{N}$-(6-ethyl-1,3-benzothiazol-2-yl)acetamide, $\mathbf{5 9}$.

Reaction run at $2.5 \mathrm{mmol}$ scale and $473 \mathrm{mg}(86 \%)$ of off white solid was isolated.

${ }^{1} \mathrm{H} \mathrm{NMR}\left(\mathrm{CDCl}_{3}, 400 \mathrm{MHz}\right): 10.01$ (s, 1H), 7.69 (m, 2H), 7.31 (m, 1H), 2.80 (q, J= $\left.7.5 \mathrm{~Hz}, 2 \mathrm{H}\right), 2.32$ (s, $3 \mathrm{H}), 1.32(\mathrm{t}, 3 \mathrm{H}) \mathrm{ppm}$.

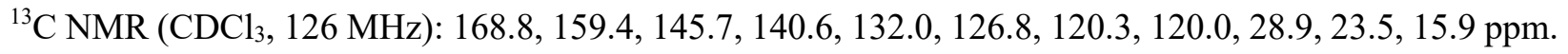
HRMS Calculated for $+\left[\mathrm{C}_{11} \mathrm{H}_{12} \mathrm{~N}_{2} \mathrm{OS}+\mathrm{H}\right]^{+}: 221.0743$, Found: 221.0737. 
<smiles>COC(=O)Cn1nc(C(F)(F)F)c2c1CCCC2</smiles>

methyl [3-(trifluoromethyl)-4,5,6,7-tetrahydro-1H-indazol-1-yl]acetate, $6 \mathbf{0 0}$.

Reaction run at $2.0 \mathrm{mmol}$ scale and $347 \mathrm{mg}(66 \%)$ of white solid was isolated.

${ }^{1} \mathrm{H}$ NMR $\left(\mathrm{CDCl}_{3}, 400 \mathrm{MHz}\right): 4.82$ (s, 2H), 3.76 (s, 3H), 2.56 (m, 4H), 1.80 (m, 4H) ppm.

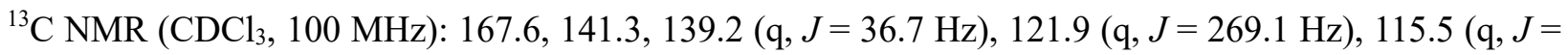
$1.5 \mathrm{~Hz}), 52.7,50.5,22.2,22.0,21.1,19.9 \mathrm{ppm}$.

${ }^{19} \mathrm{~F}$ NMR (377 MHz, $\mathrm{CDCl}_{3}$ ): $-61.7 \mathrm{ppm}$.

HRMS Calculated for $+\left[\mathrm{C}_{11} \mathrm{H}_{13} \mathrm{~F}_{3} \mathrm{~N}_{2} \mathrm{O}_{2}+\mathrm{H}\right]^{+}:$263.1002, Found: 263.0999.

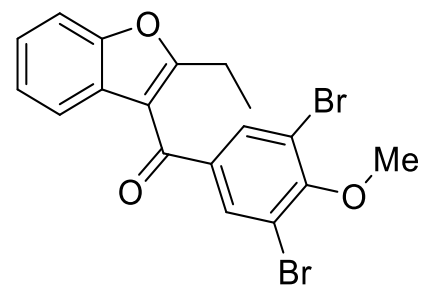

(3,5-dibromo-4-methoxyphenyl)(2-ethyl-1-benzofuran-3-yl)methanone, 61.

Reaction run at $4.0 \mathrm{mmol}$ scale and $1.67 \mathrm{~g}(95 \%)$ of white solid was isolated.

${ }^{1} \mathrm{H} \mathrm{NMR}\left(\mathrm{CDCl}_{3}, 400 \mathrm{MHz}\right): 8.01(\mathrm{~s}, 2 \mathrm{H}), 7.53$ (dt, $\left.J=8.2 \mathrm{~Hz}, J=0.9 \mathrm{~Hz}, 1 \mathrm{H}\right), 7.44(\mathrm{dt}, J=7.6 \mathrm{~Hz}, J=$ $0.9 \mathrm{~Hz}, 1 \mathrm{H}), 7.34$ (ddd, $J=8.3 \mathrm{~Hz}, J=7.3 \mathrm{~Hz}, J=1.5 \mathrm{~Hz}, 1 \mathrm{H}), 7.27(\mathrm{td}, J=7.5 \mathrm{~Hz}, J=1.1 \mathrm{~Hz}, 1 \mathrm{H}), 4.01$ (s, 3H), $2.92(\mathrm{q}, J=7.5 \mathrm{~Hz}, 2 \mathrm{H}), 1.38(\mathrm{t}, J=7.5 \mathrm{~Hz}, 3 \mathrm{H})$

${ }^{13} \mathrm{C} \mathrm{NMR}\left(\mathrm{CDCl}_{3}, 100 \mathrm{MHz}\right): 188.1,166.9,157.7,153.7,137.2,133.6,126.4,124.7,123.9,121.0,118.5$, $115.3,111.2,60.9,22.1,12.2$.

HRMS Calculated for $+\left[\mathrm{C}_{19} \mathrm{H}_{16} \mathrm{Br}_{2} \mathrm{O}_{4}+\mathrm{H}\right]^{+}:$436.9383, Found: 436.9380 .

\section{References}

1. Altenhoff, G.; Goddard, R.; Lehmann, C. W.; Glorius, F. Sterically demanding, bioxazolinederived N-heterocyclic carbene ligands with restricted flexibility for catalysis. J. Am. Chem. Soc., 126, 15195-15201 (2004).

2. Wang, H.-L. et al. Novel vanilloid receptor-1 antagonists: 3. the identification of a secondgeneration clinical candidate with improved physicochemical and pharmacokinetic properties. J. Med. Chem. 50, 3528-3539 (2007).

3. Aoyamo, T.; Teraswa, S.; Sudo, K.; Shioiri, New Methods and Reagents in Organic Synthesis. 46. Trimethylsilyldiazomethane: a convenient reagent for the O-methylation of phenols and enols. Chem. Pharm. Bull., 32, 3759-3760 (1984).

4. Meanwell, M. et al. Direct heterobenzylic fluorination, difluorination and 
trifluoromethylthiolation with dibenzenesulfonimide derivatives. Chem. Sci. 9, 5608-5613 (2018).

5. Barba, I., Chinchilla, R., Gómez, C., Synthesis of phenyl substituted cyclohexa-1,4-dienes and cyclohexa-2,5-dienones by anodic methoxylation of alkylbiphenyls. Tetrahedron 46, 7813-7822 (1990)

6. Sudalai, A., Talluri, S. K. NBS-catalyzed hydroamination and hydroalkoxylation of activated styrenes. Org. Lett., 7, 855-857 (2005).

7 Sawama, Y. et al. Chemoselective and direct functionalization of methyl benzyl ethers and unsymmetrical dibenzyl ethers by ssing iron trichloride. Chem. Eur. J. 20, 2631-2636 (2014).

8. LaLonde, R. T., Ferrara, P. B. Reacrions of arylcyclopronpanes with n-bromosuccinimide in hydroxylic solvents. J. Org. Chem., 37, 2502-2505 (1972).

9. Guinaudau, H. et al. (+)-Uskudaramine: A novel type aporphine-benzylisoquinoline alkaloid. J. Org. Chem. 47, 5406-5407 (1982).

10. Tokumaru, T.; Nakata, $\mathrm{K}$. $\mathrm{InCl}_{3}$-promoted intramolecular decarboxylative etherification of bzenzylic carbonates. Tetrahedron Lett., 56, 2336-2339 (2015).

11. Min, S., Yoshiki, O. Setsuo, T. Photolysis of tetraarylmethanes and 3(triarylmethyl)pyridines Bull. Chem. Soc. Jpn. 63, 2731-2733 (1990).

12. Masui, Y., Hattori, T., Onaka, M. Reversible Generation of labile secondary carbocations from alcohols in the nanospace of $\mathrm{H}$-mordenite and their long-lasting preservation at ambient temperature. J. Am. Chem. Soc. 139, 8612-8620, (2017).

13. Kuribayashi, T. et al. Patent Appl. WO 2009131129 A1 20091029 (2009).

14. Bauer, V. J. et al. Synthesis of spiro[isobenzofuran-1(3H),4'-piperidines] as potential central nervous system agents. 1, J. Med. Chem., 19, 1315-1324 (1976).

15. Kulkarni, G. C., Karmarkar, S. N., Kelkar, S. L., Wadia S. M. Generation of $\alpha$ - acylcarbenium ions : a novel uncatalysed C-C bond formation at room temperature. Tetrahedron., 44, 51895198 (1988). 


\section{NMR spectral Data}

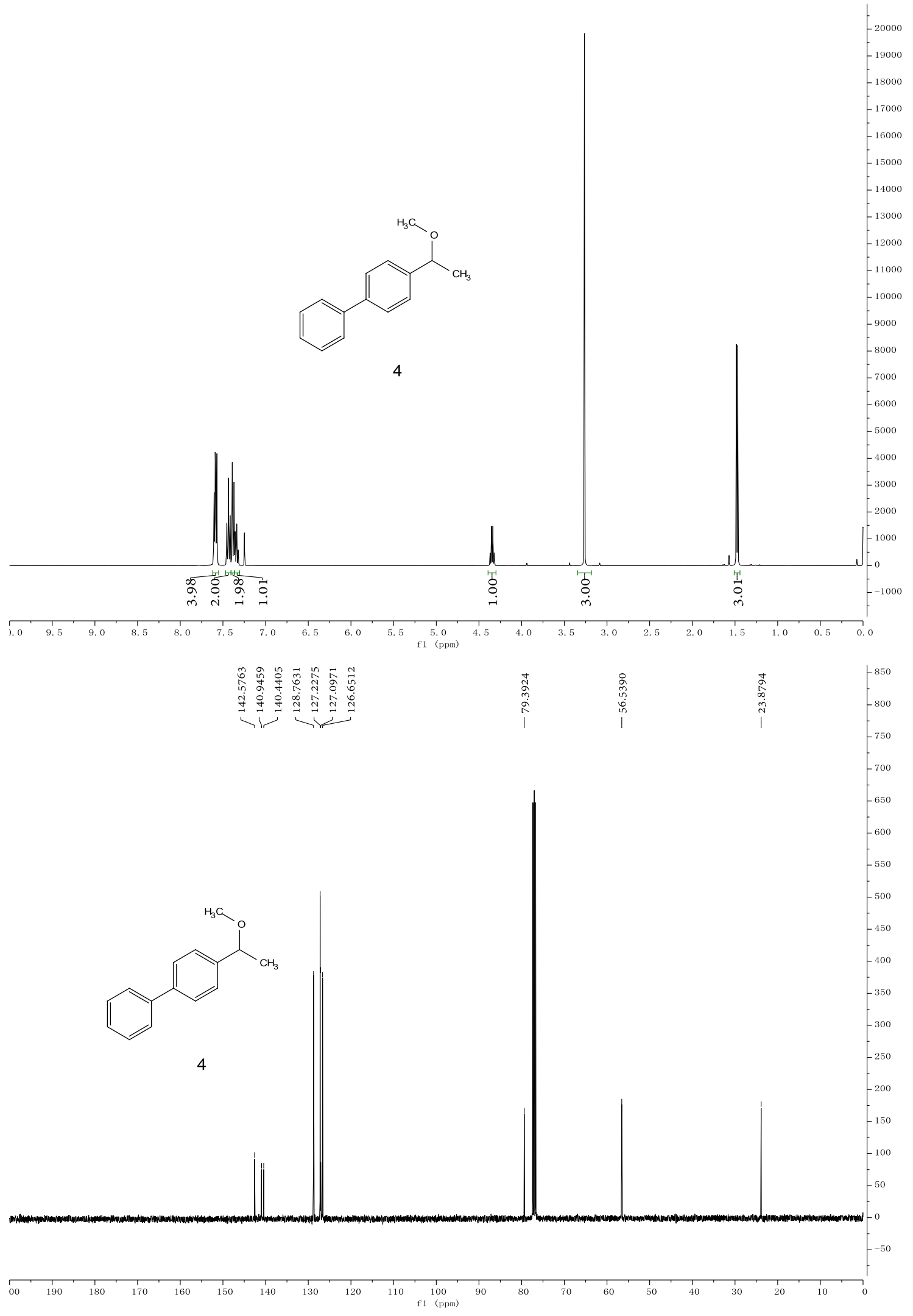




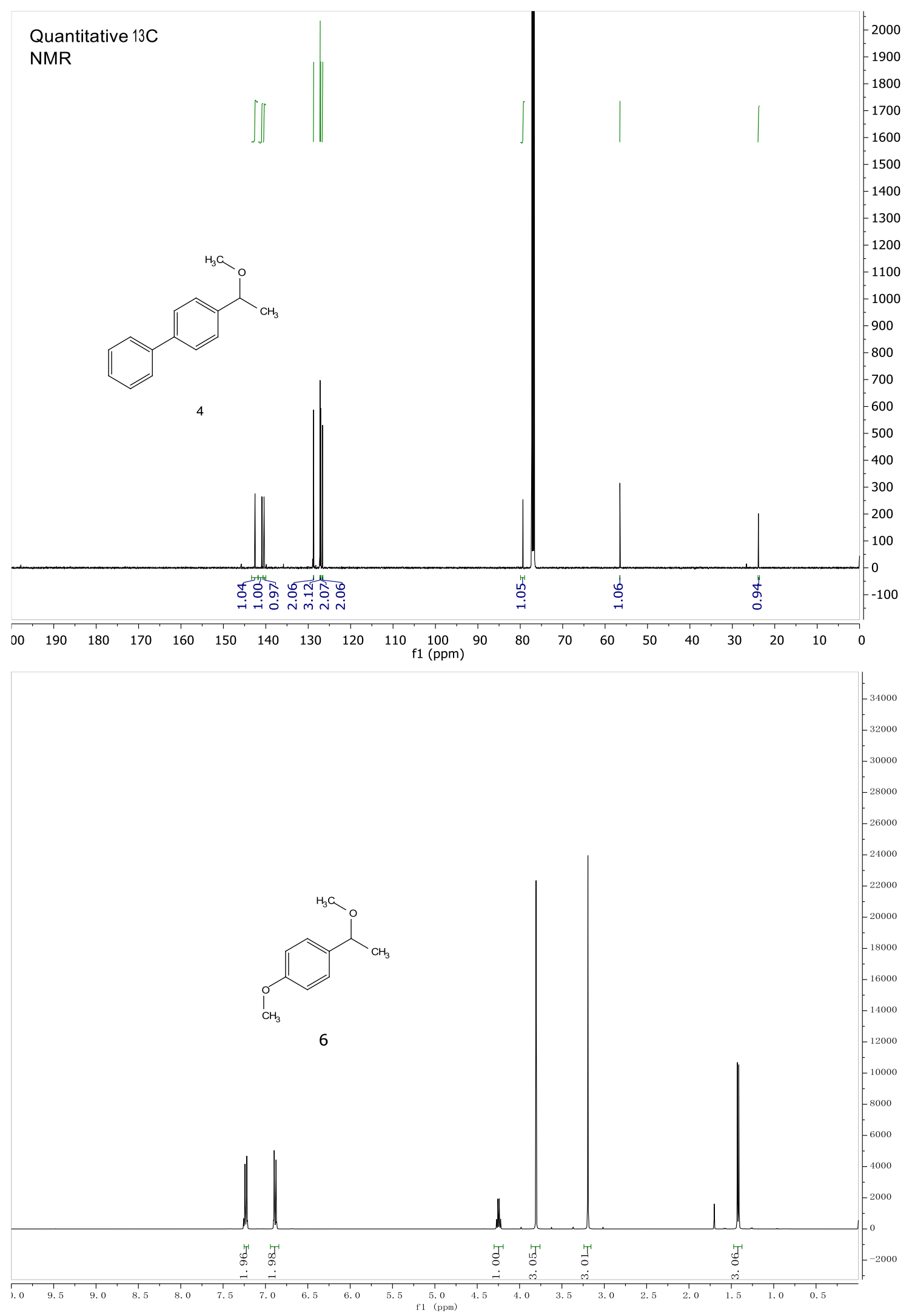




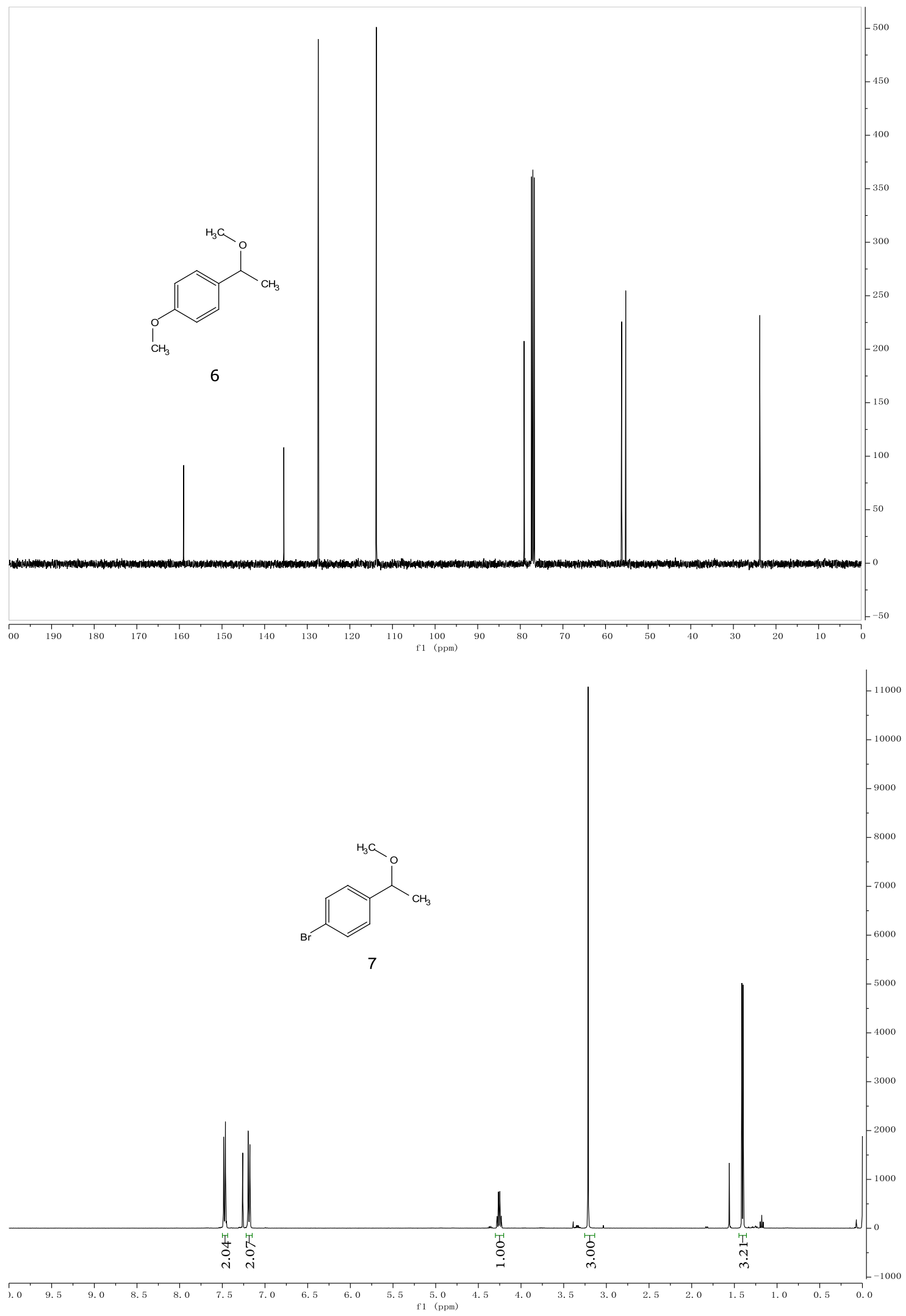




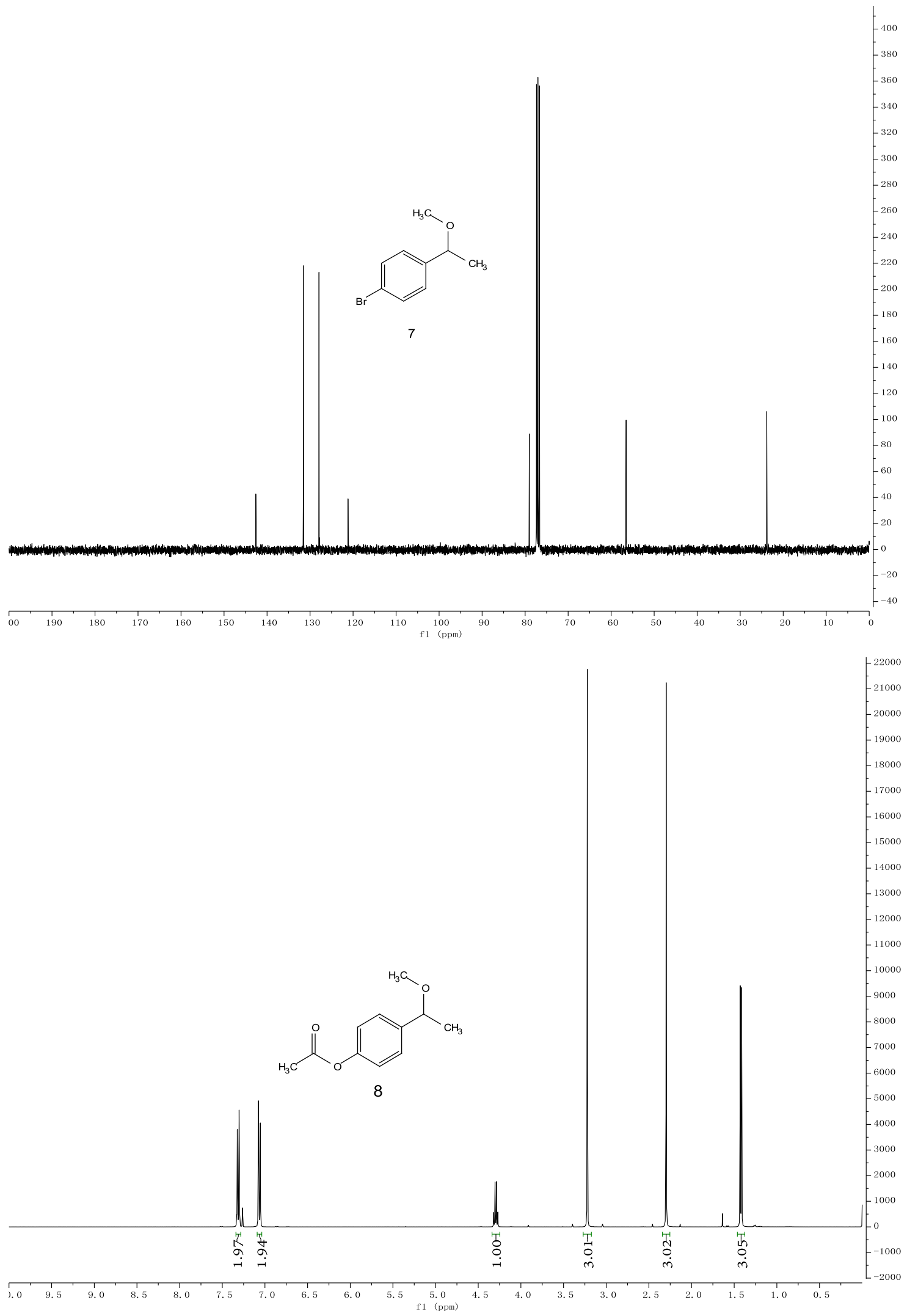



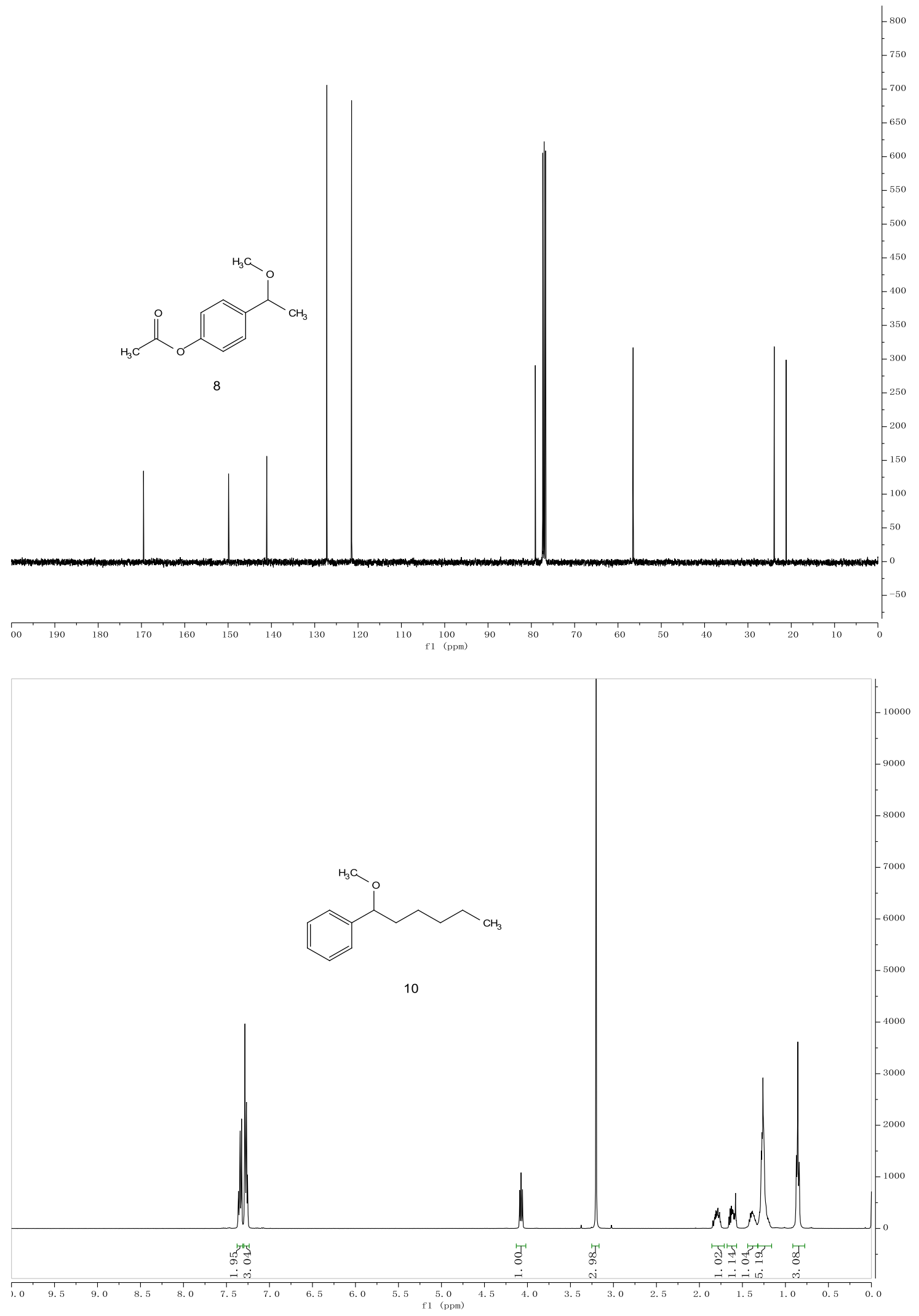

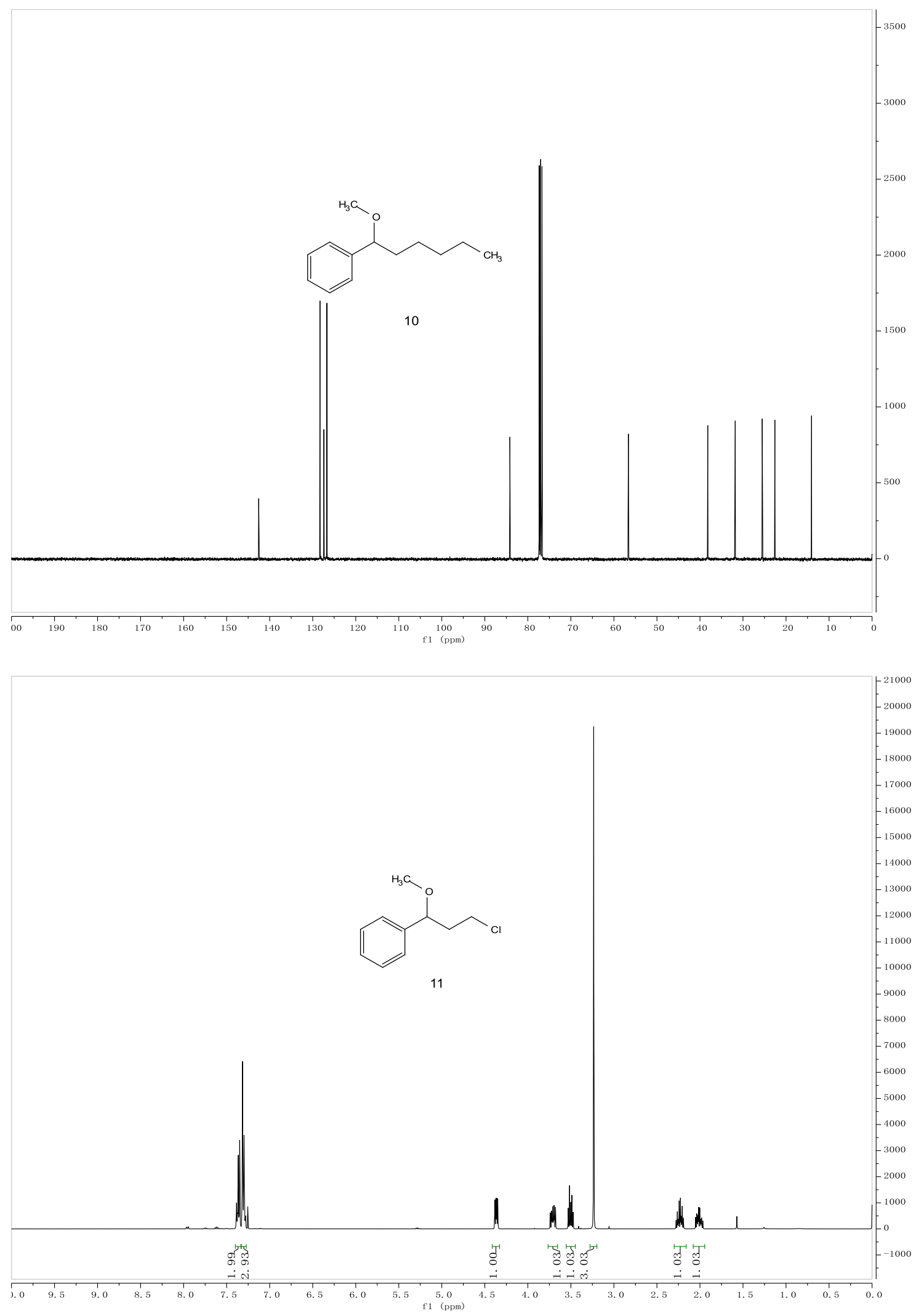

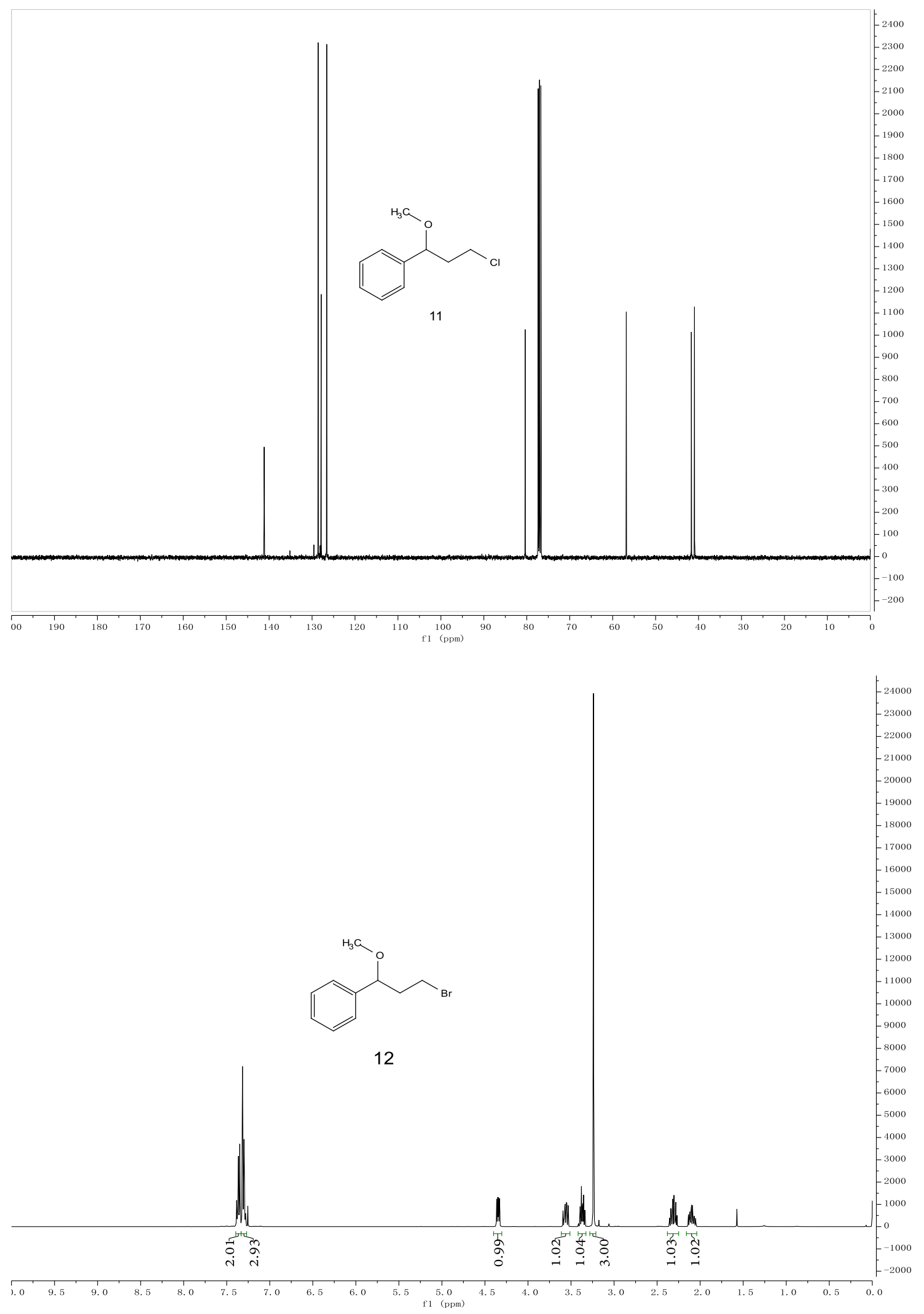

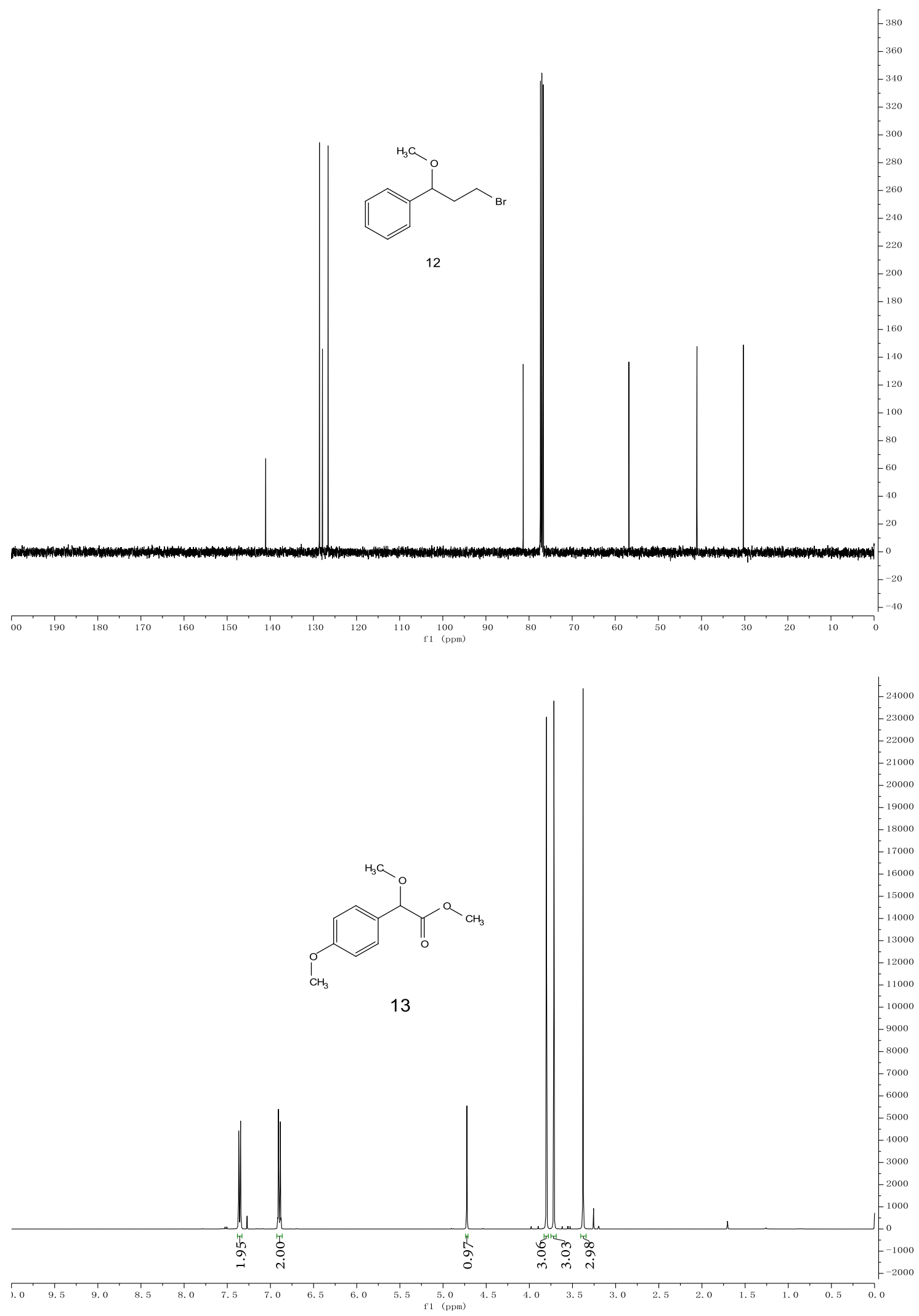


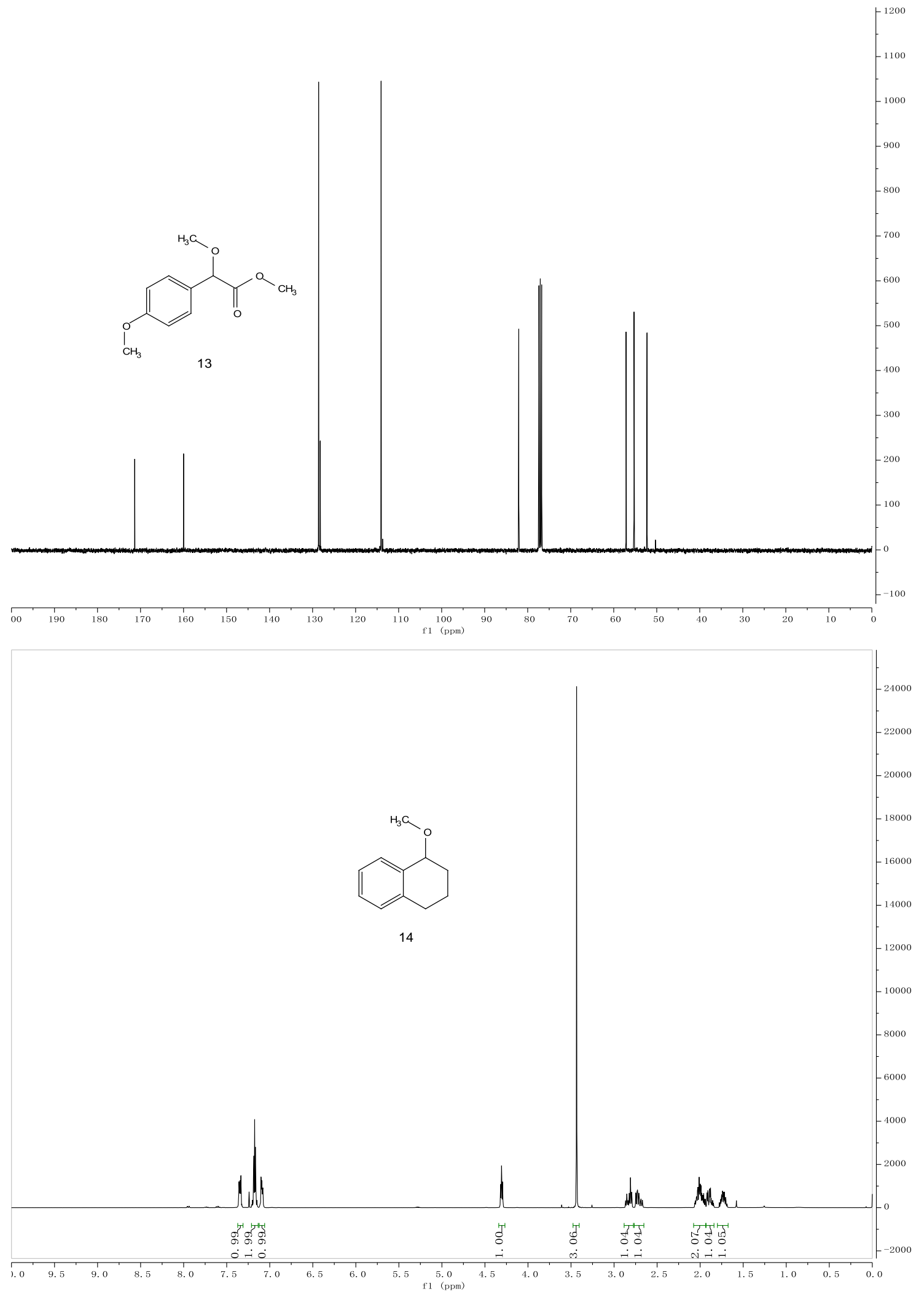



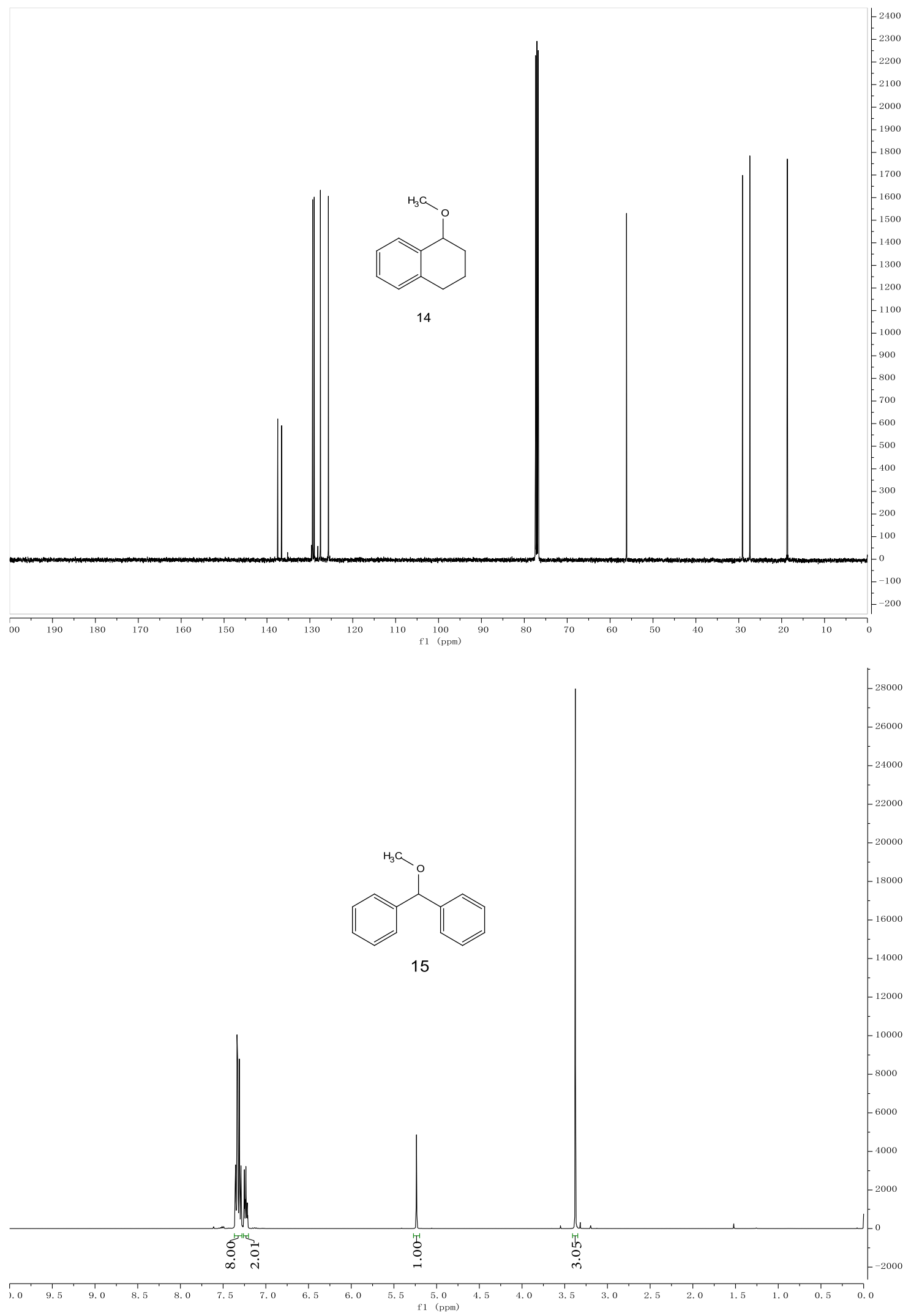

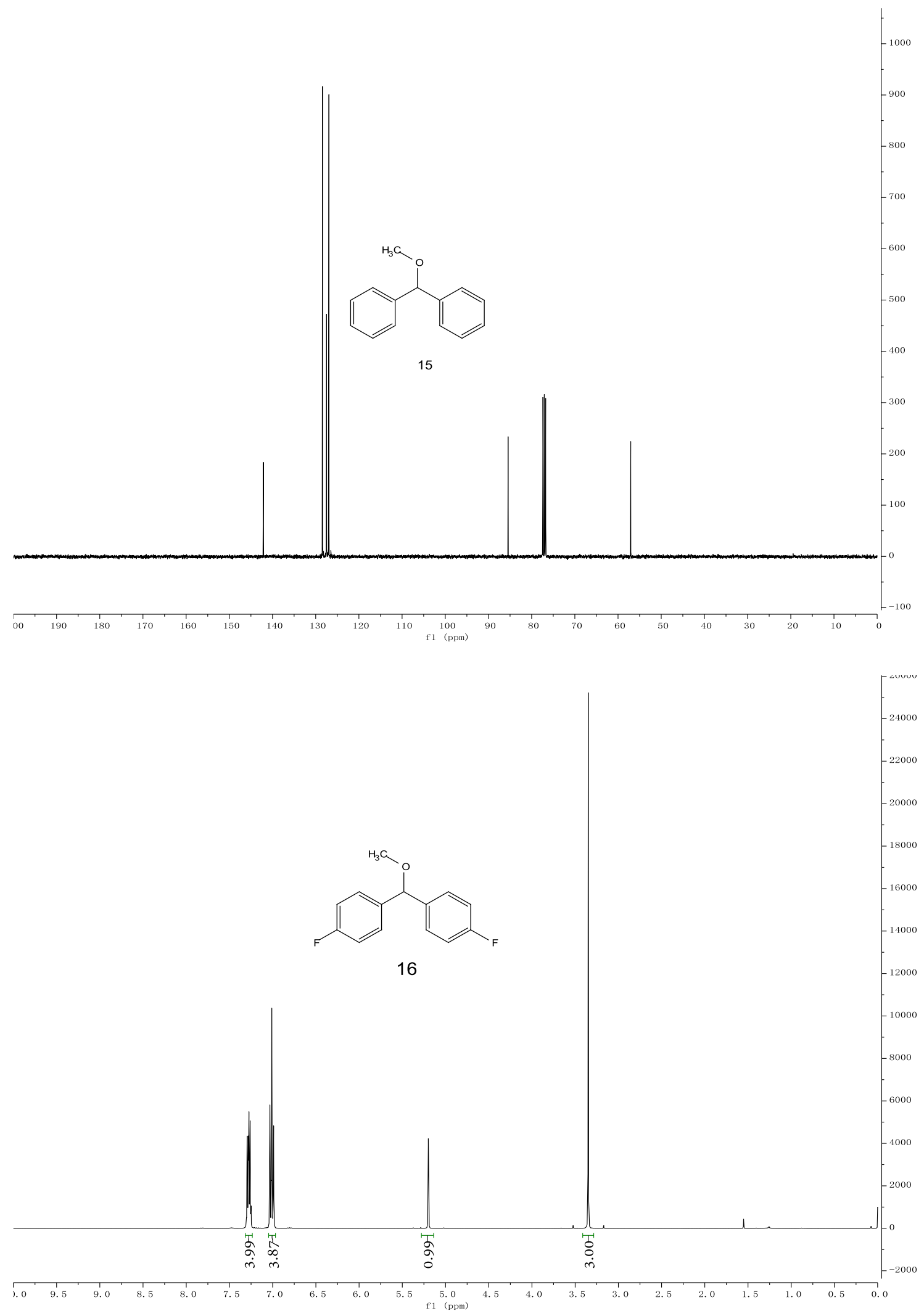

S43 

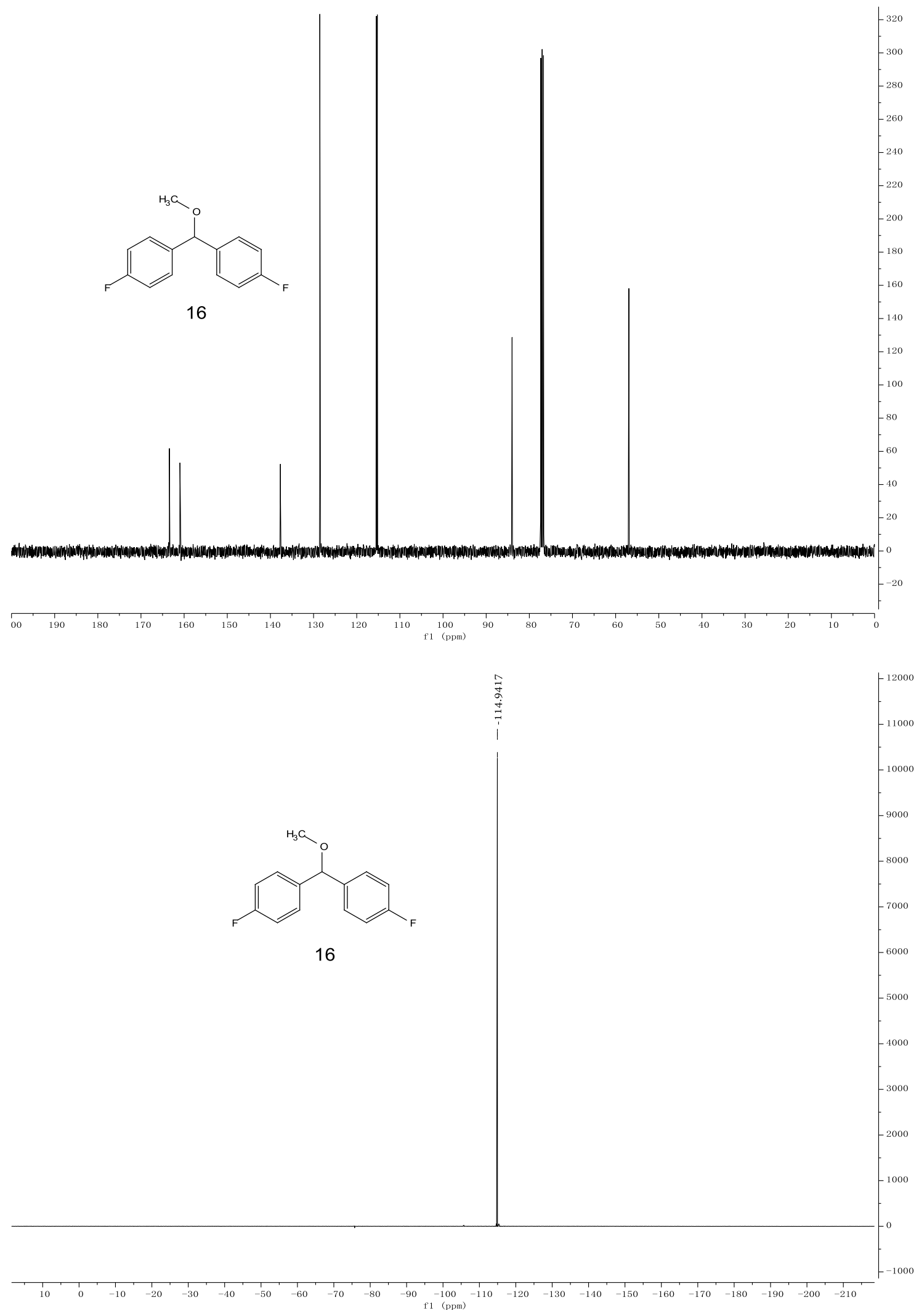

S44 

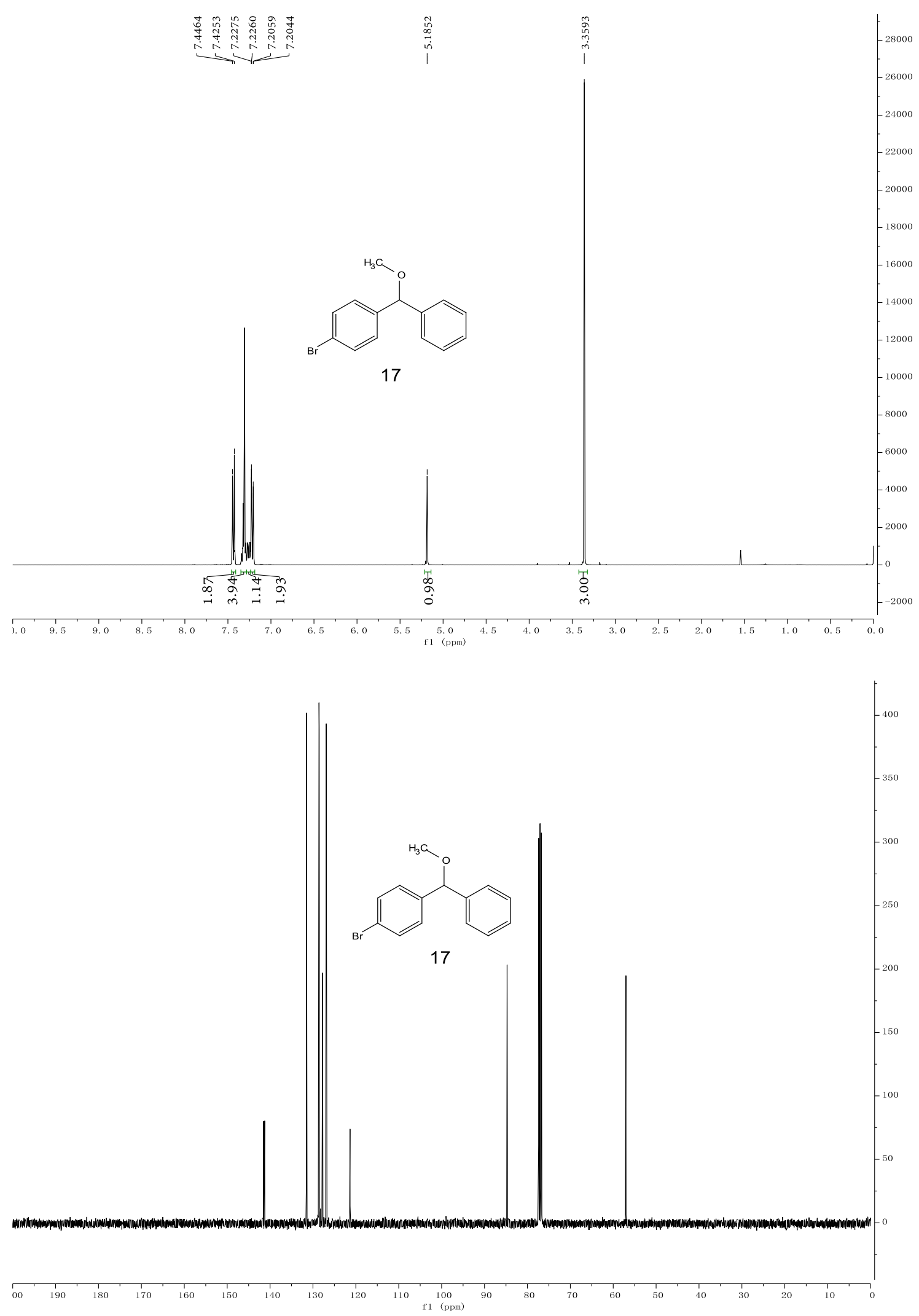

S45 

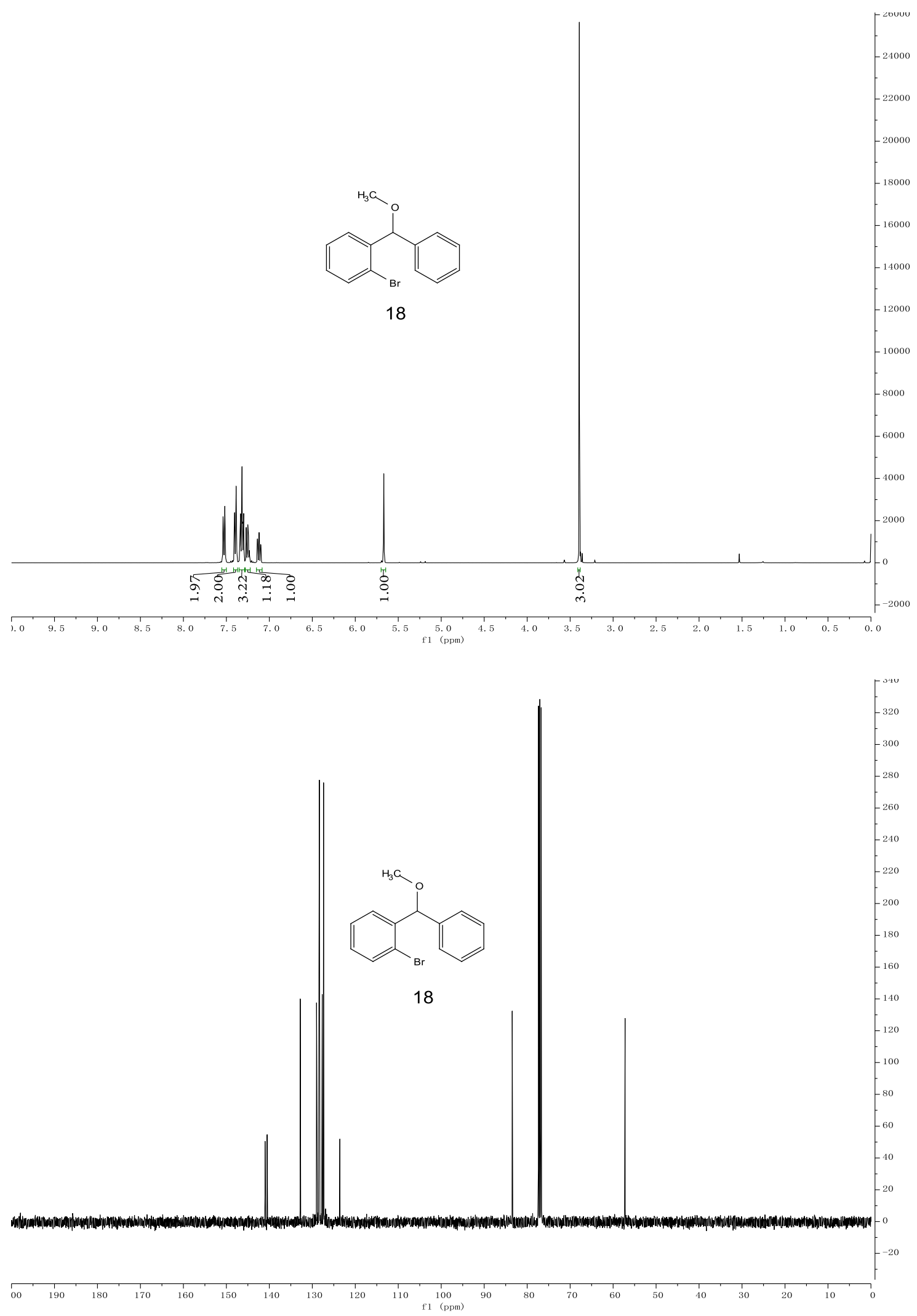


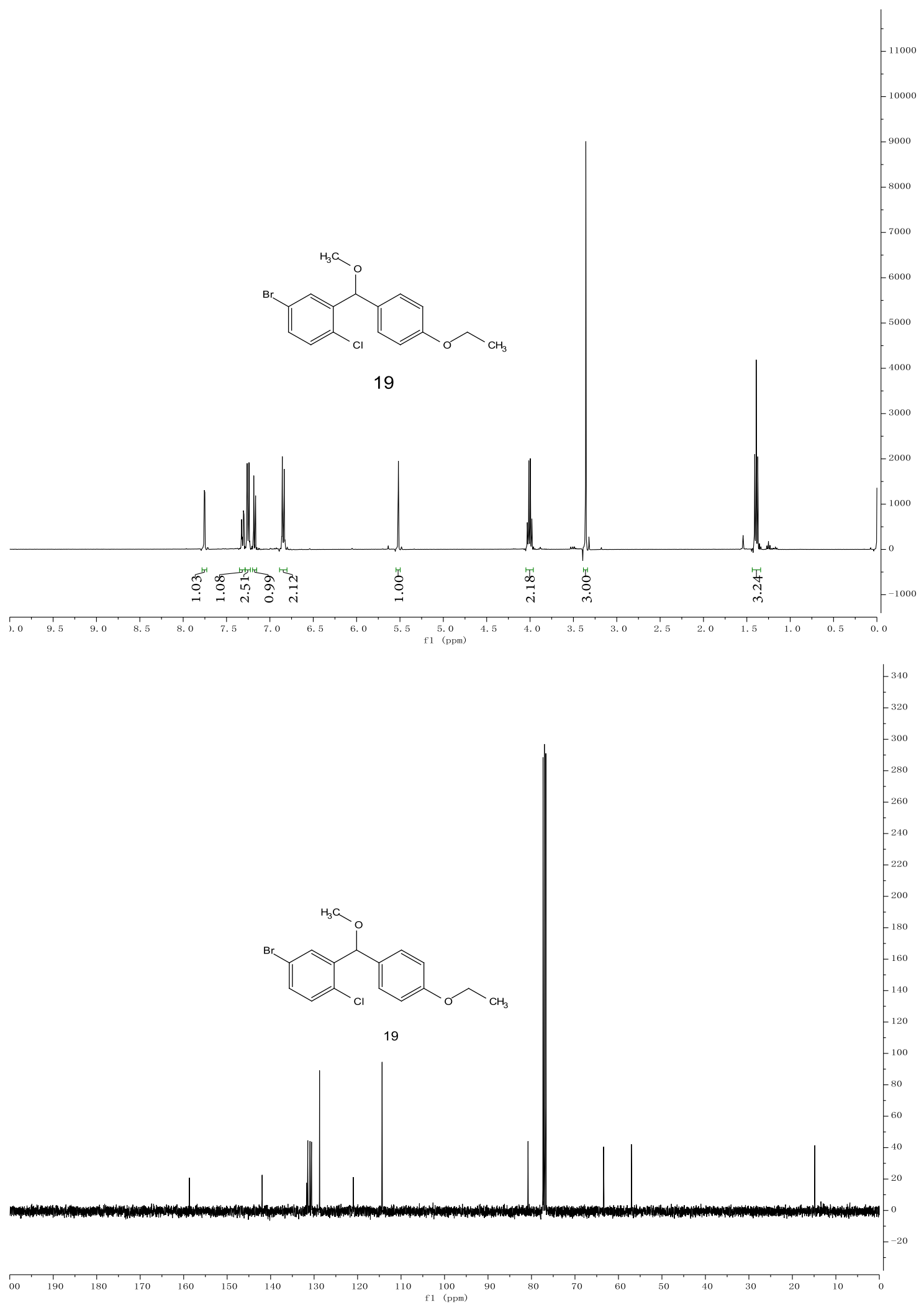




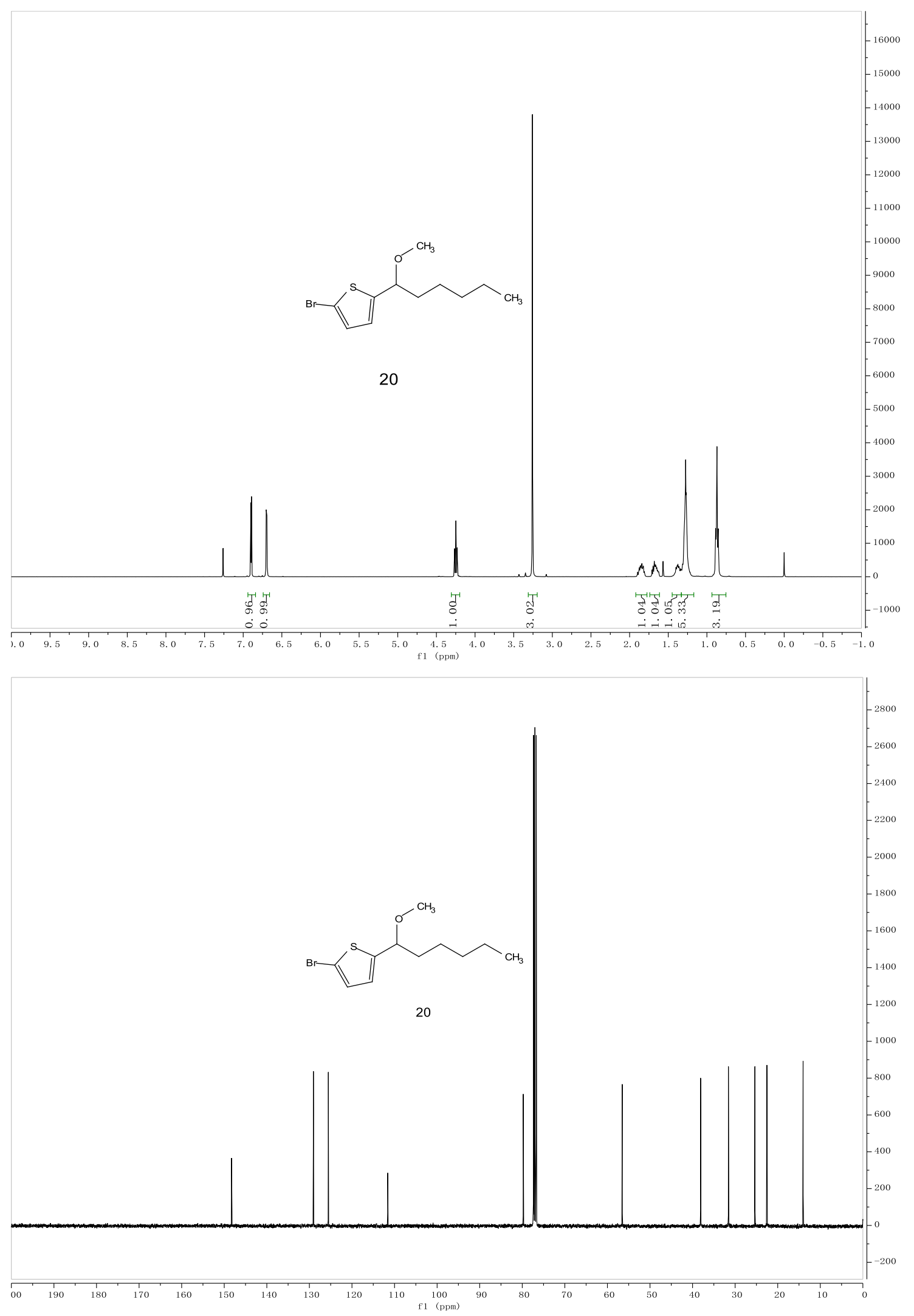



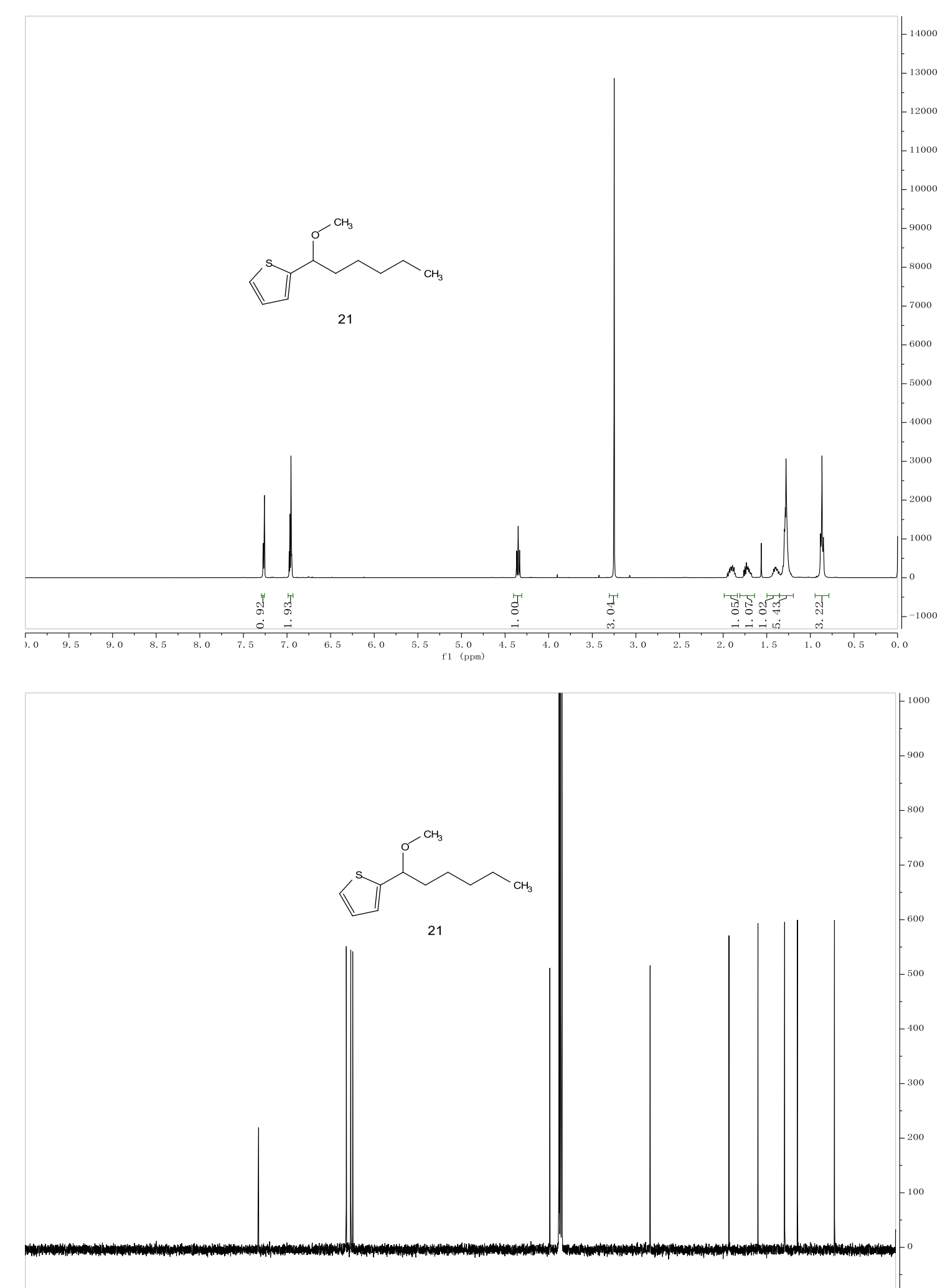


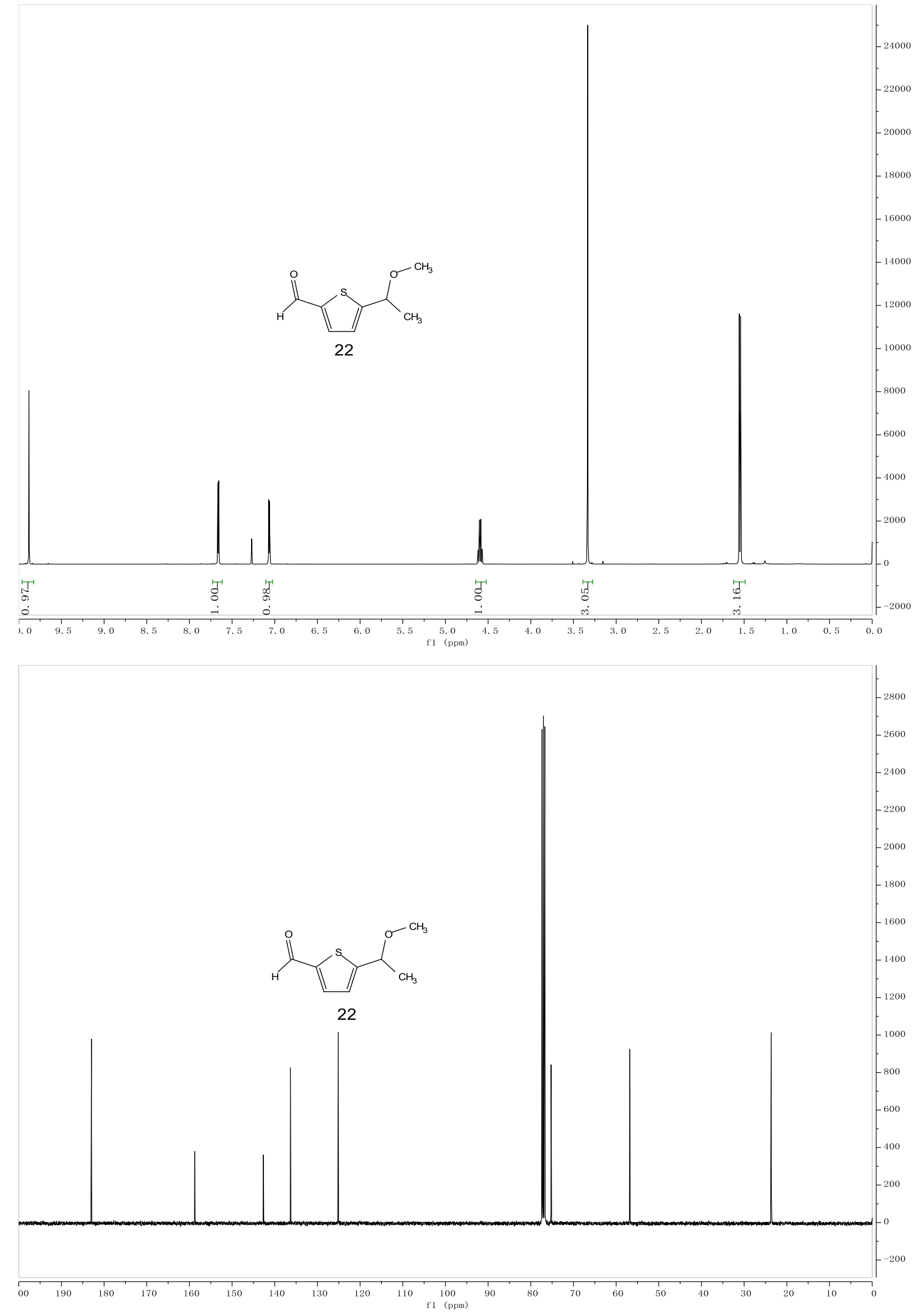



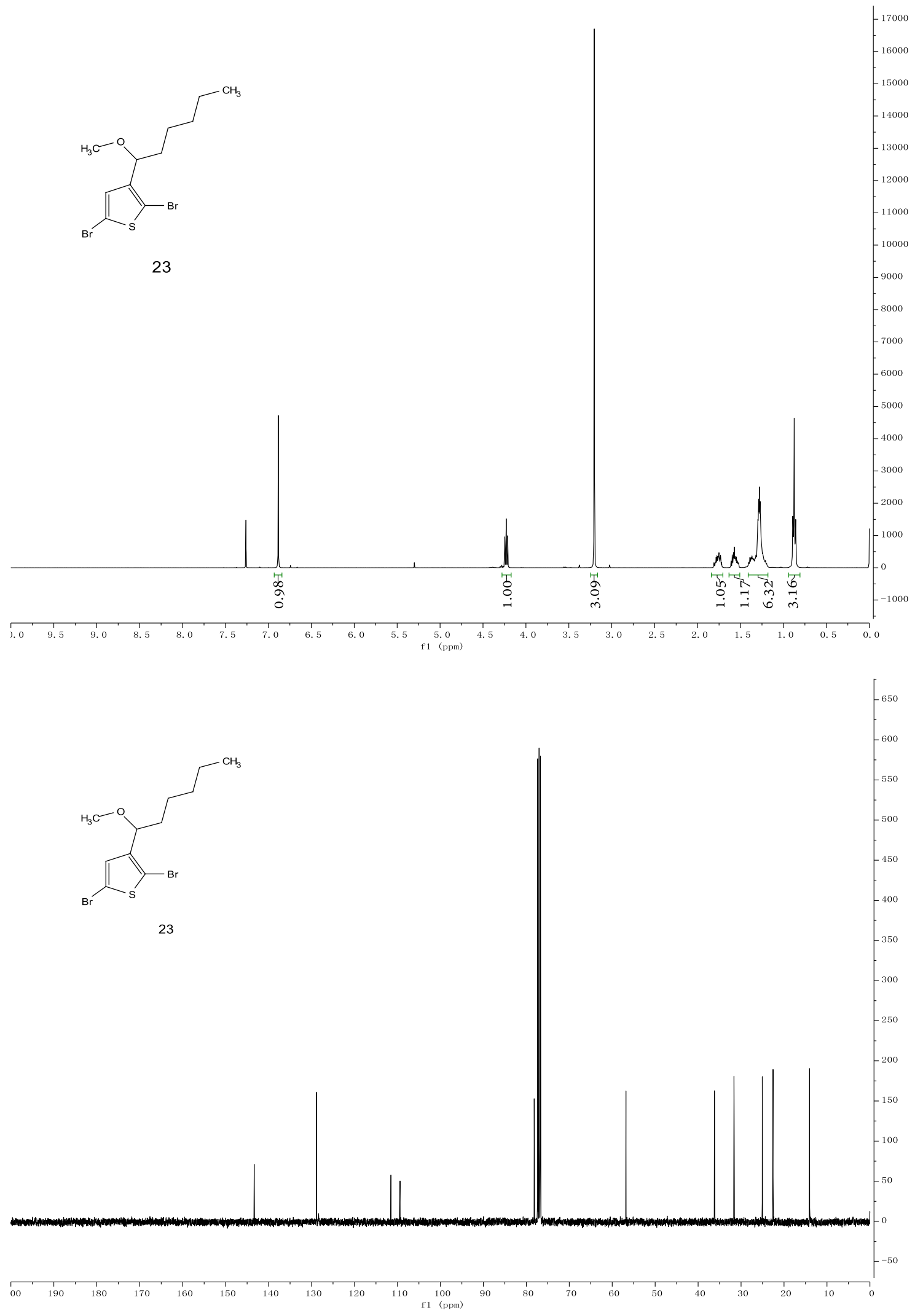

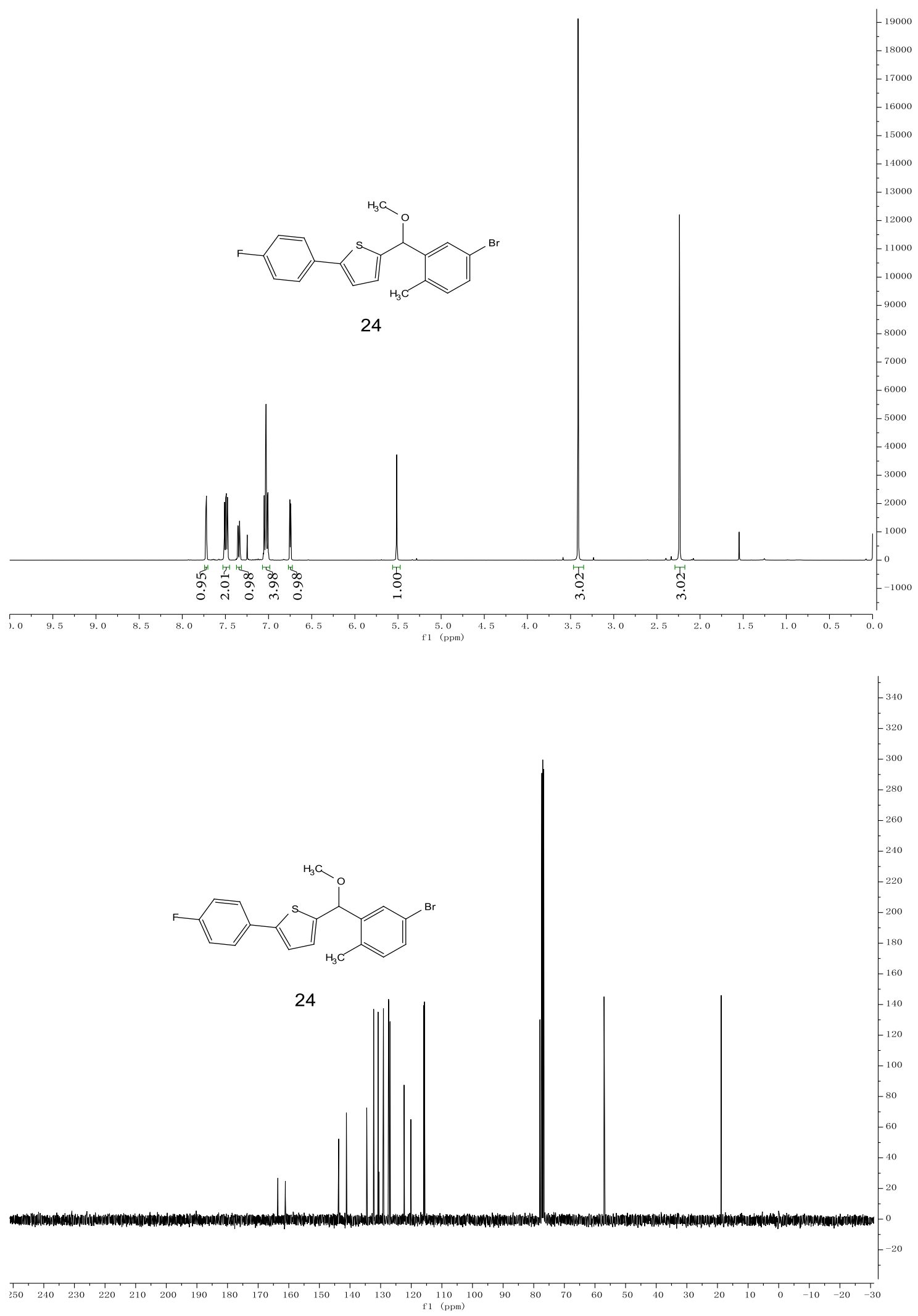


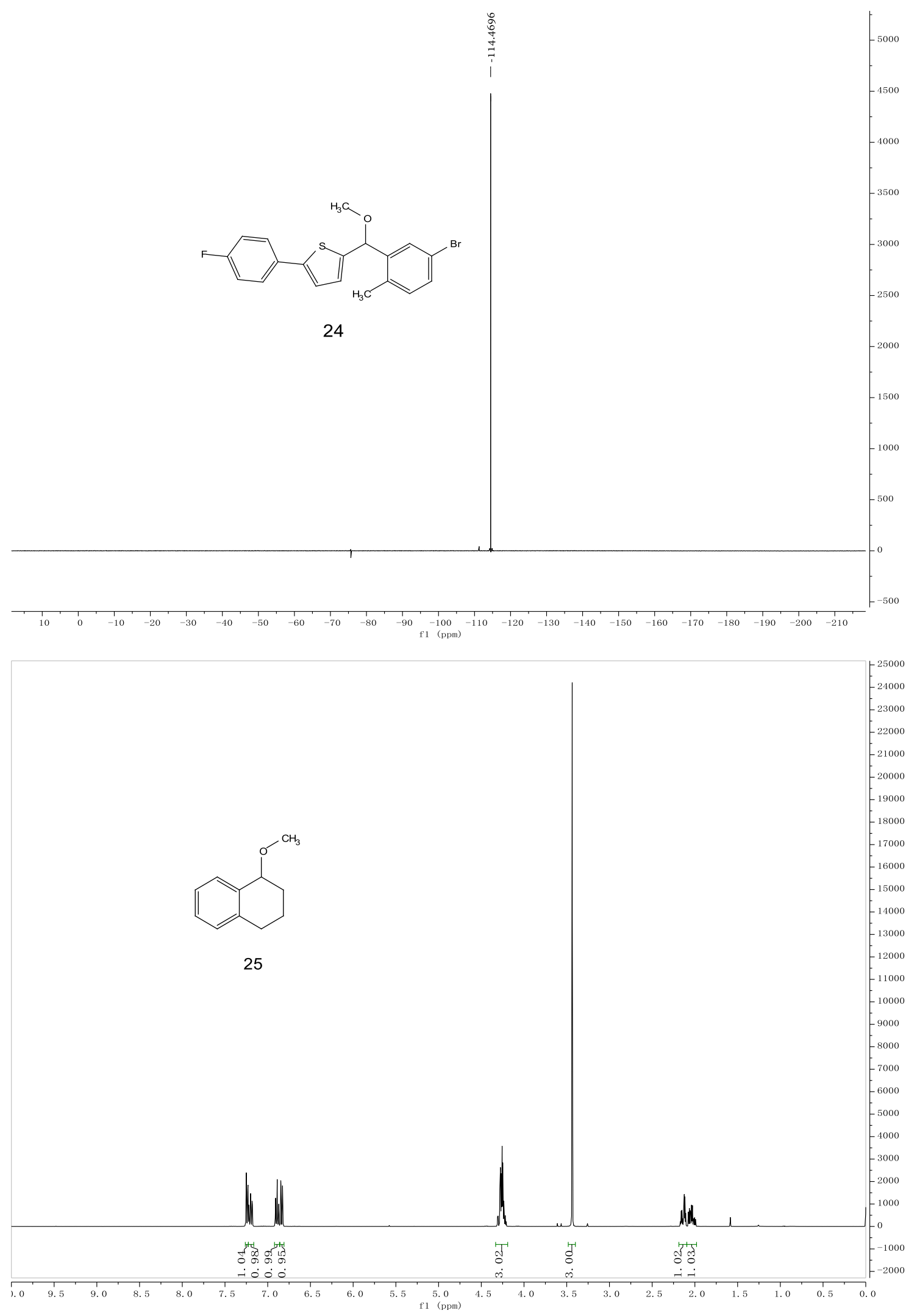




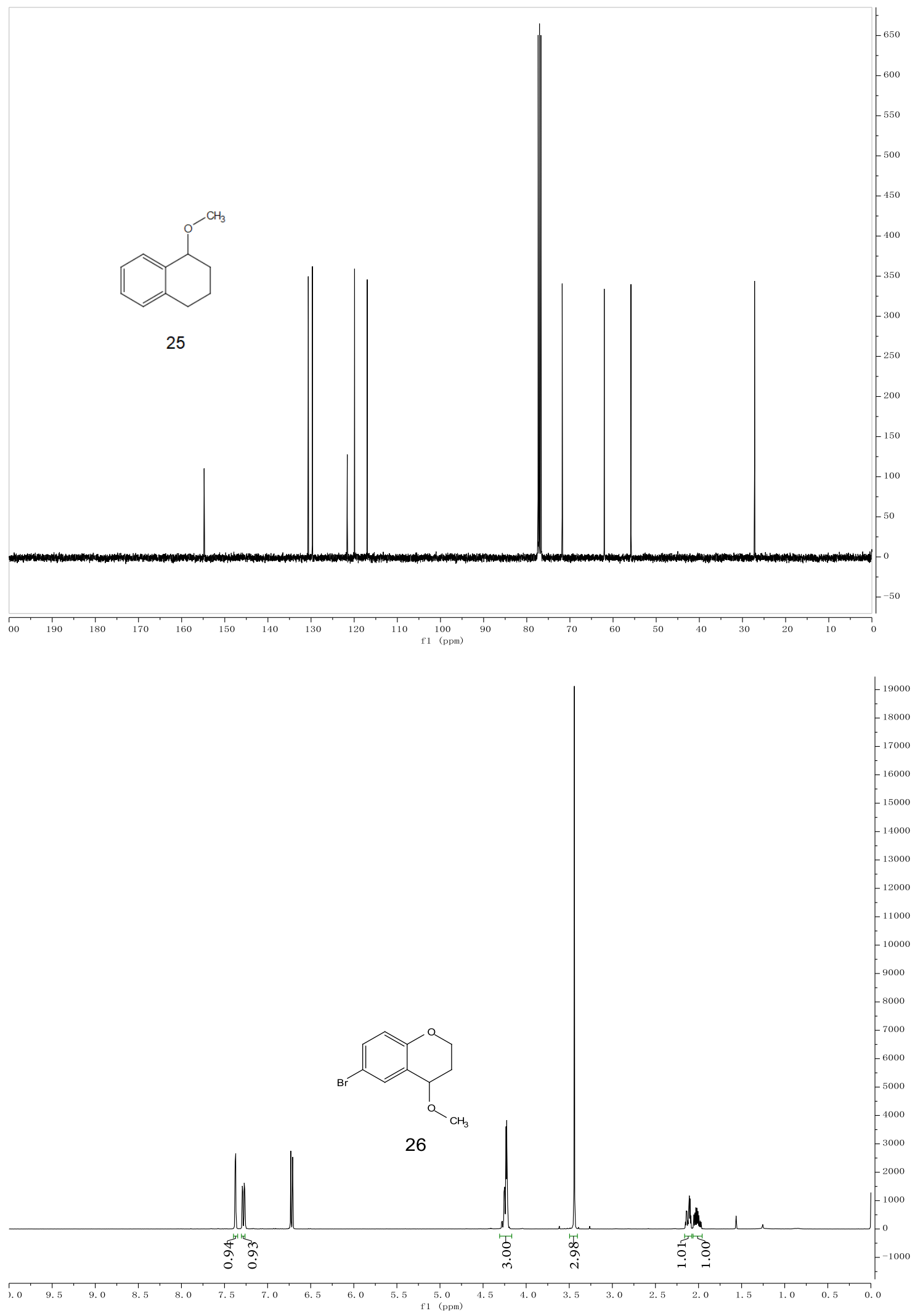




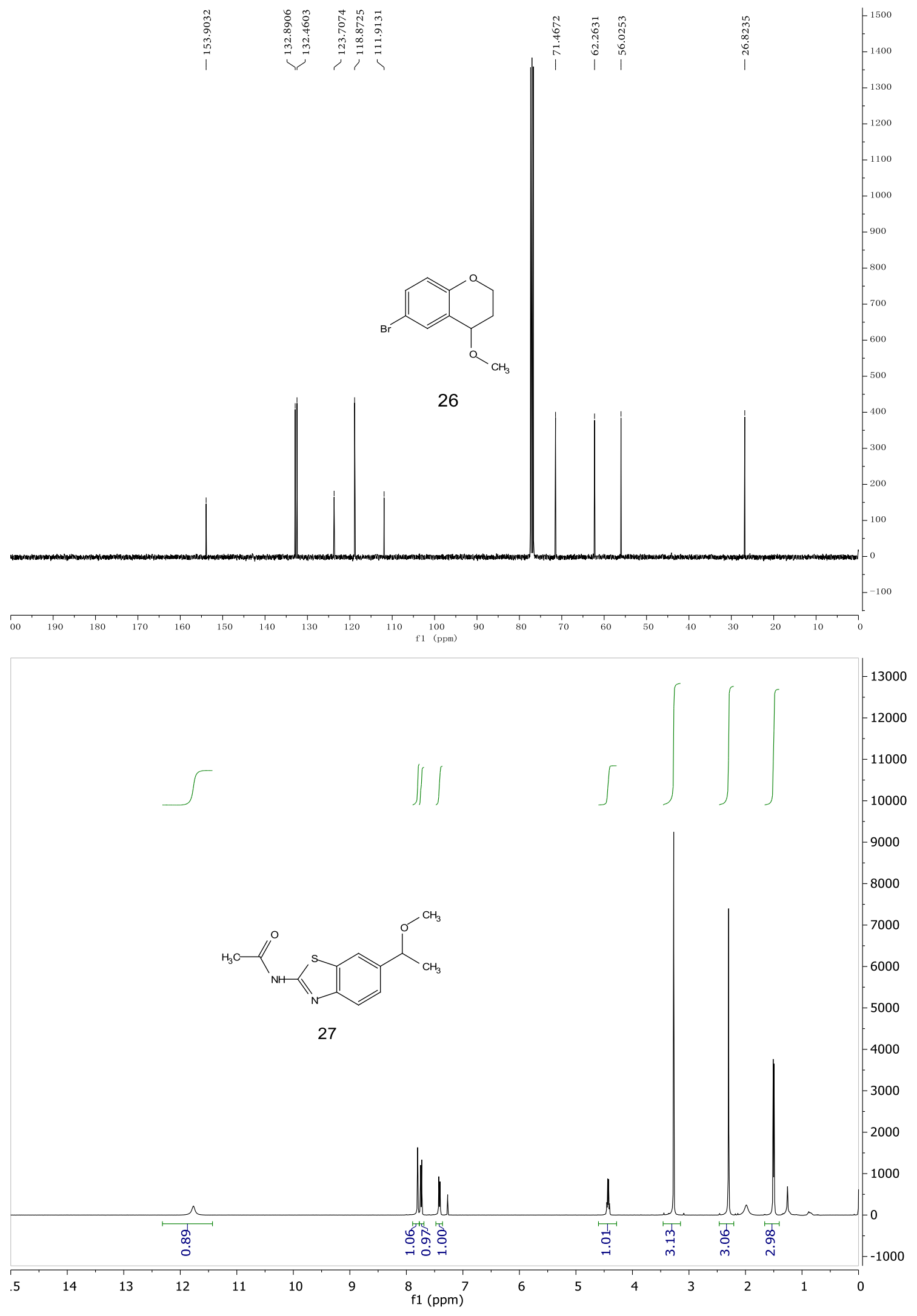




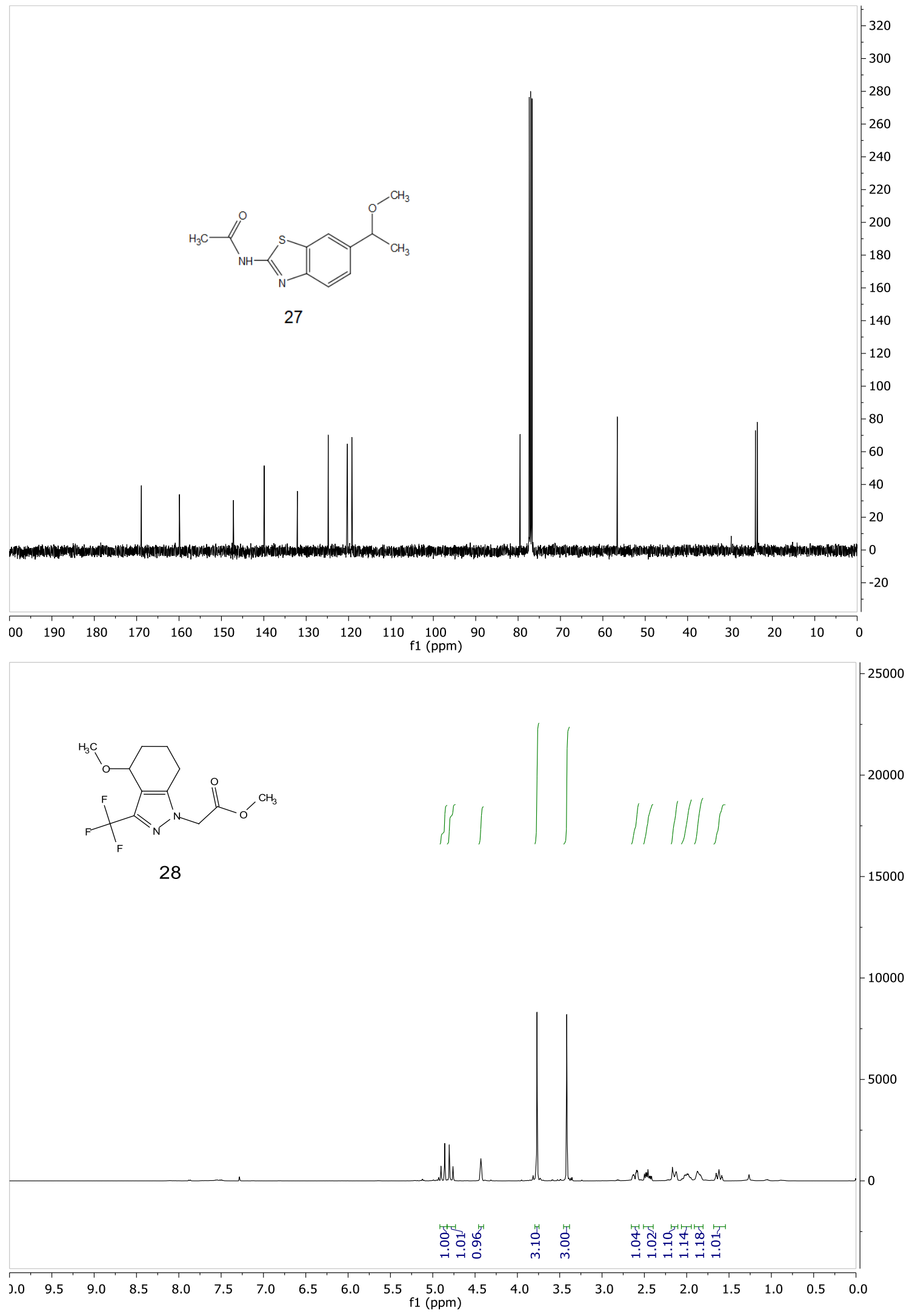




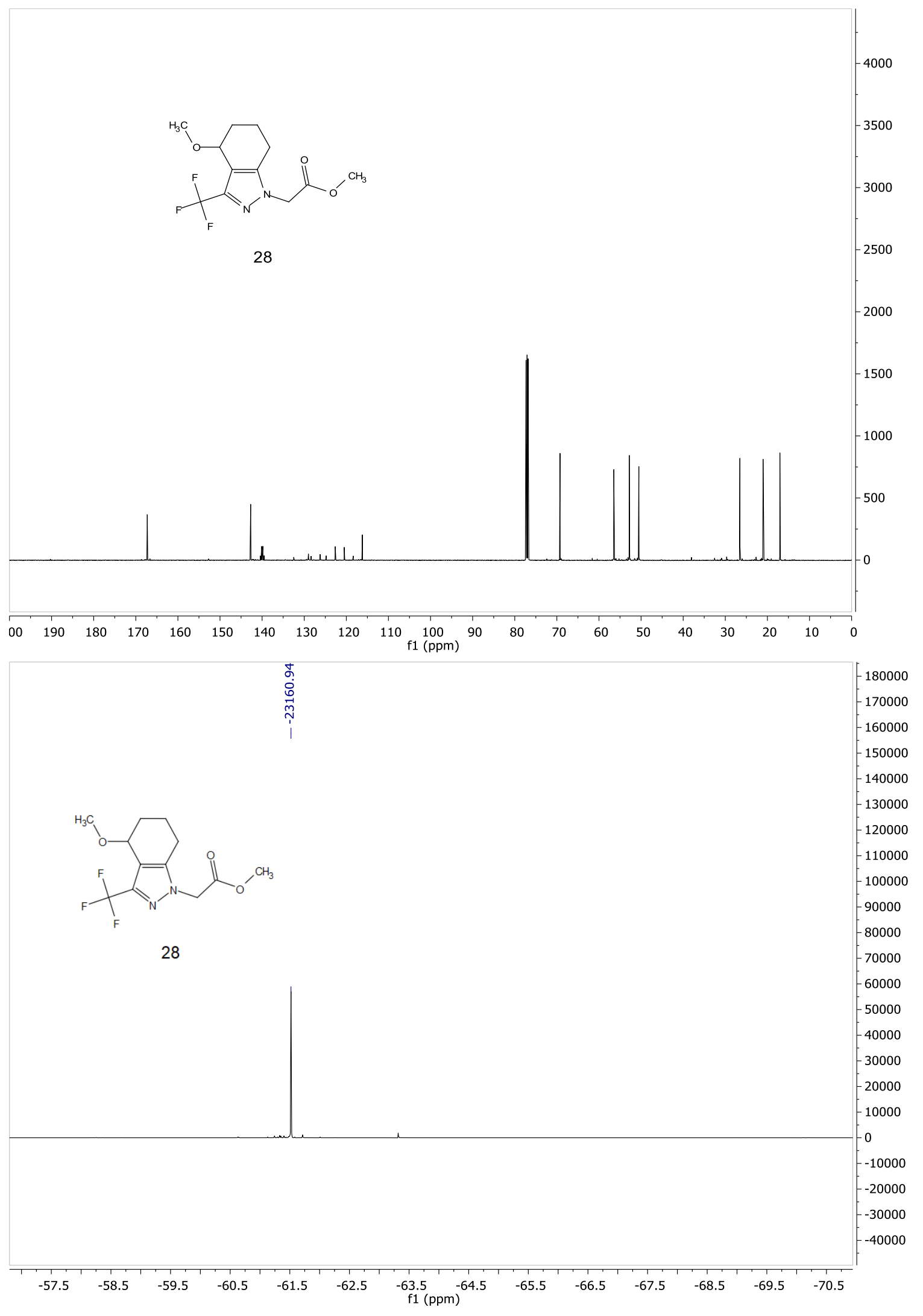




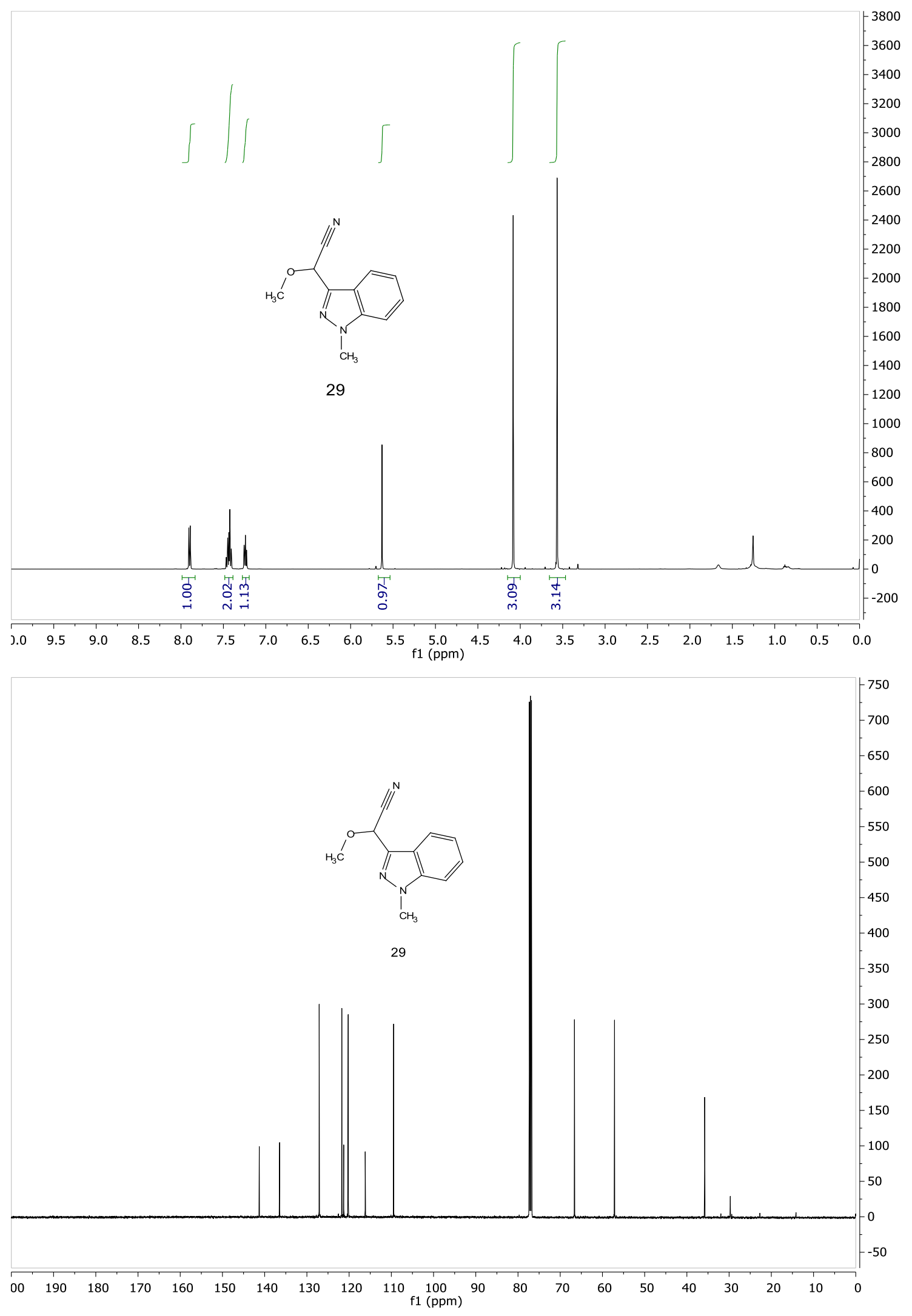




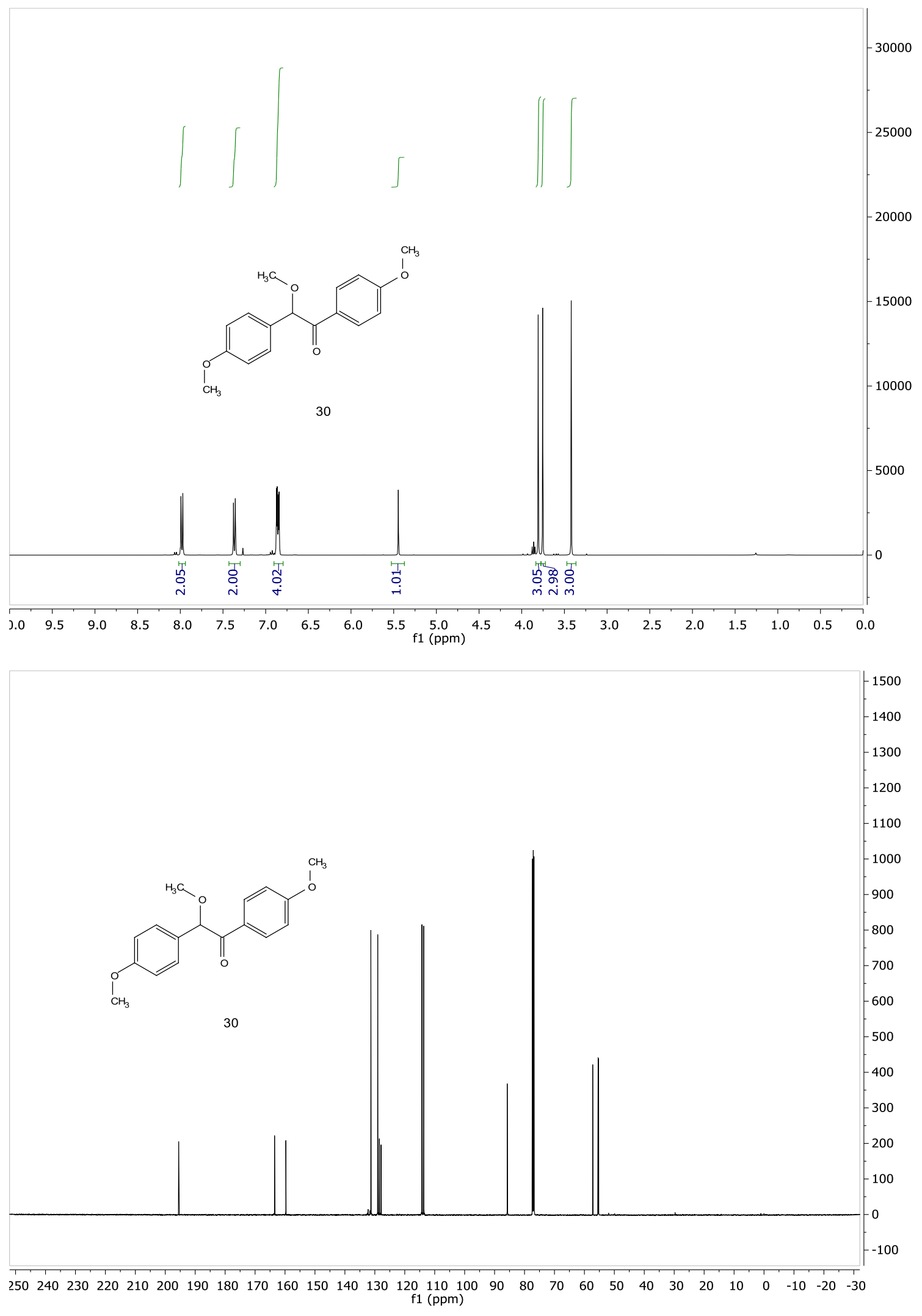



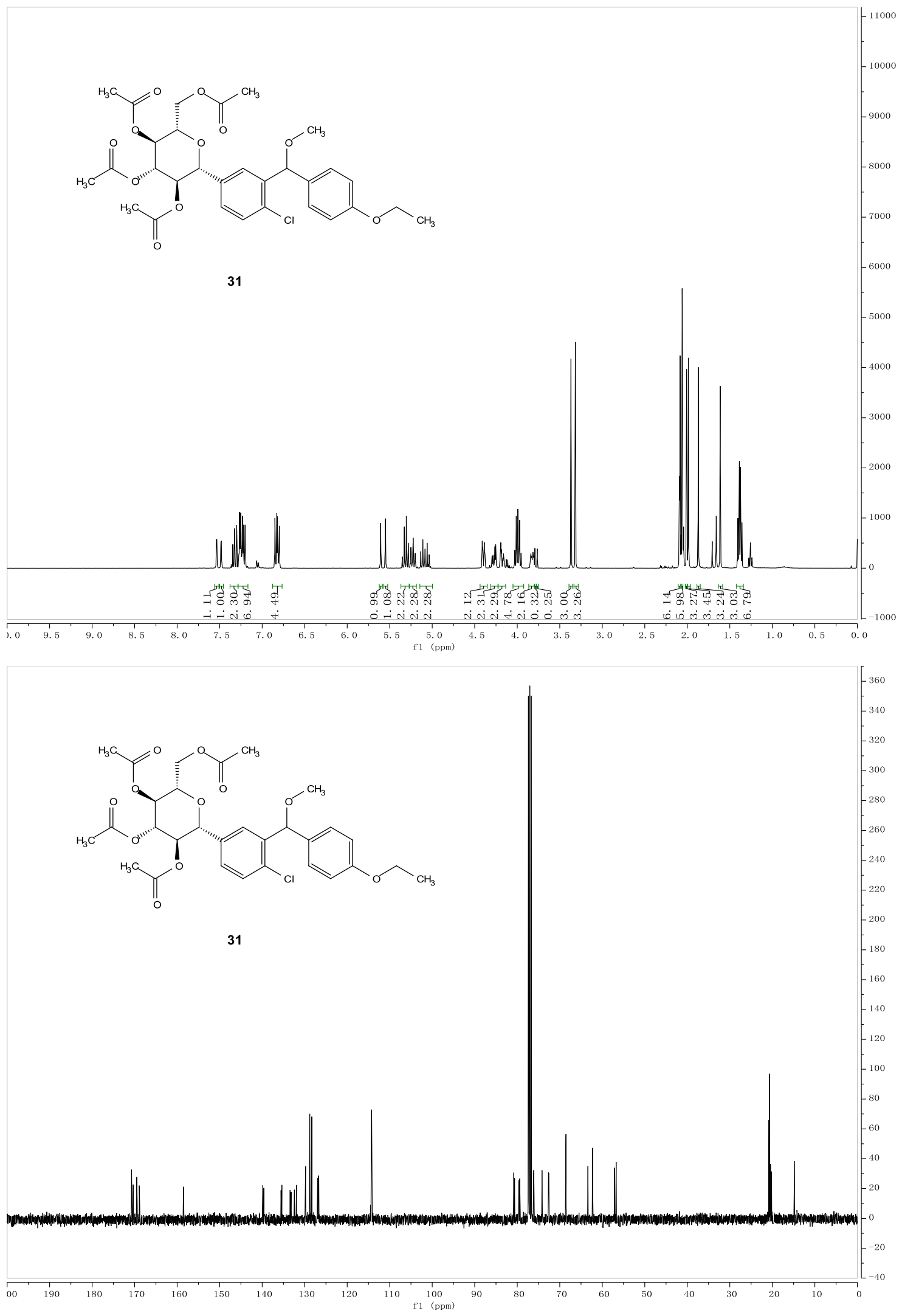

S60 


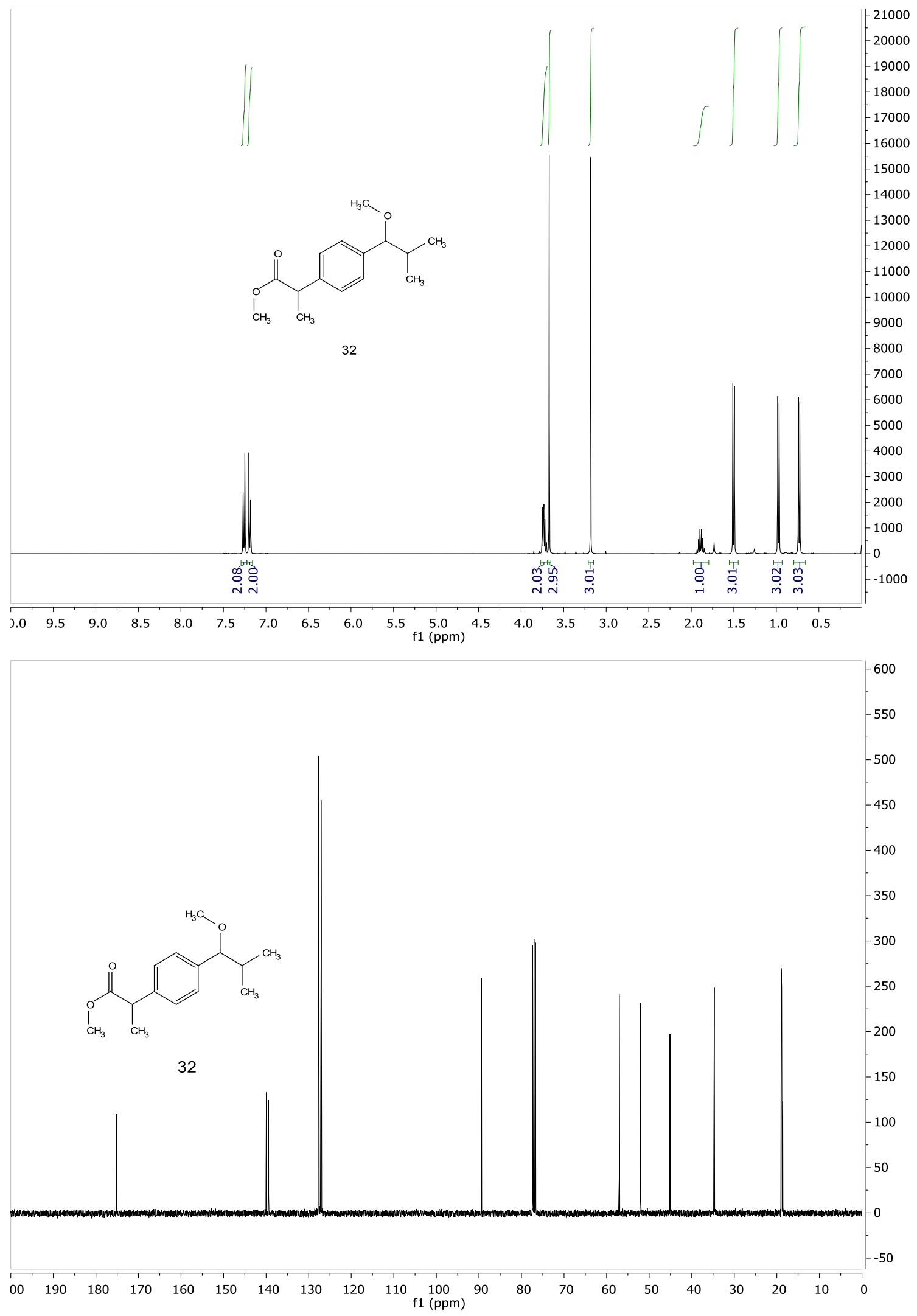




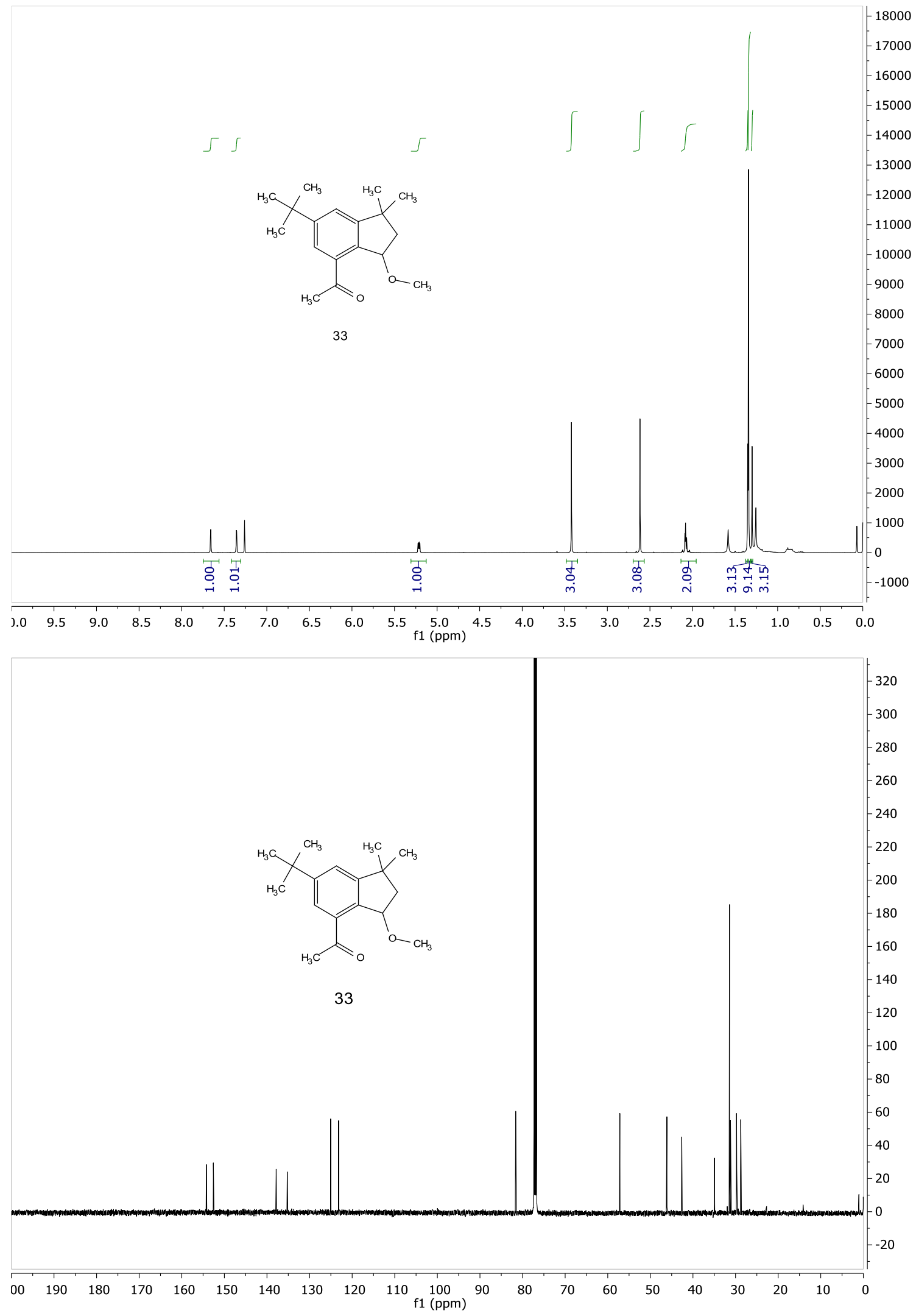




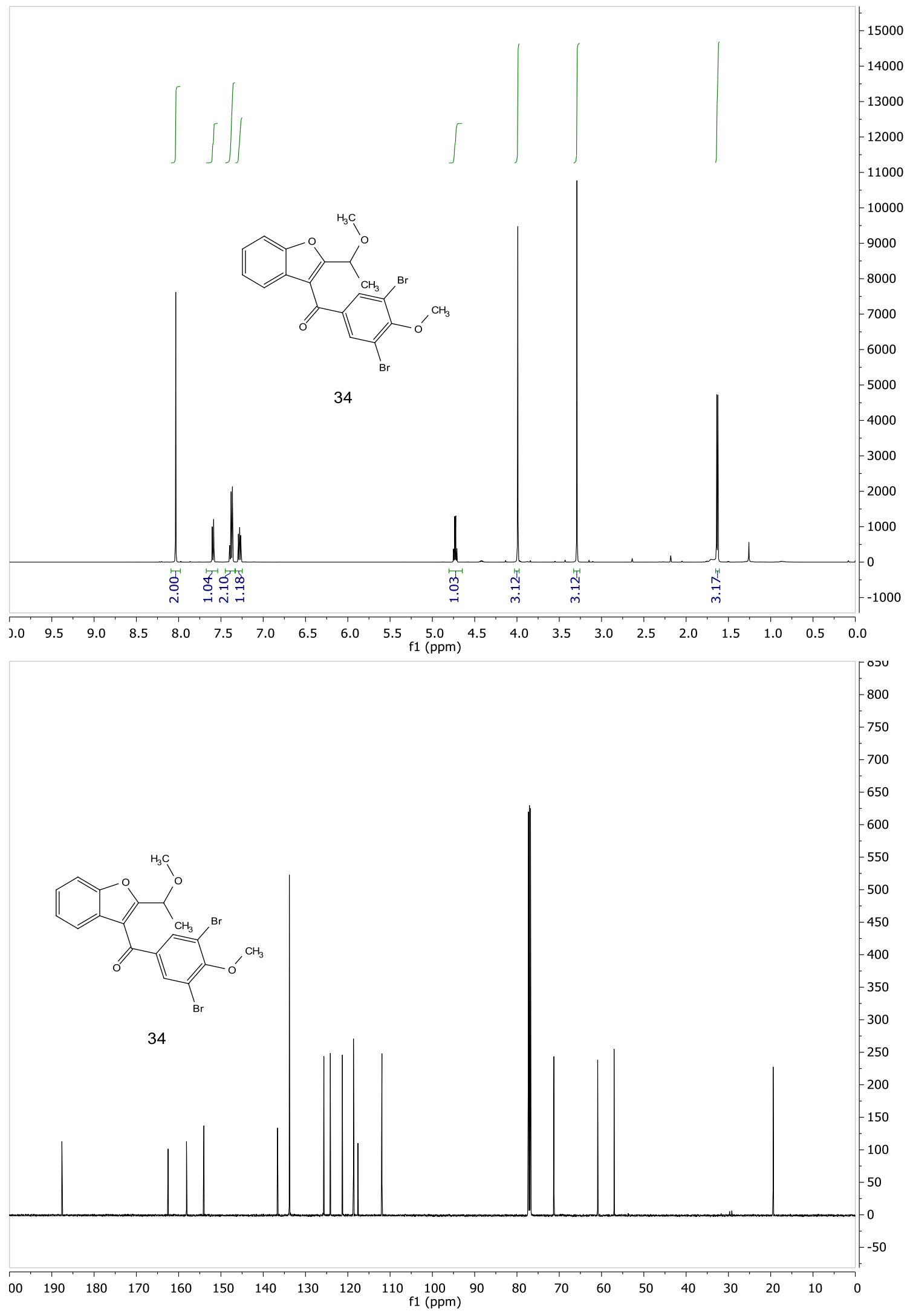




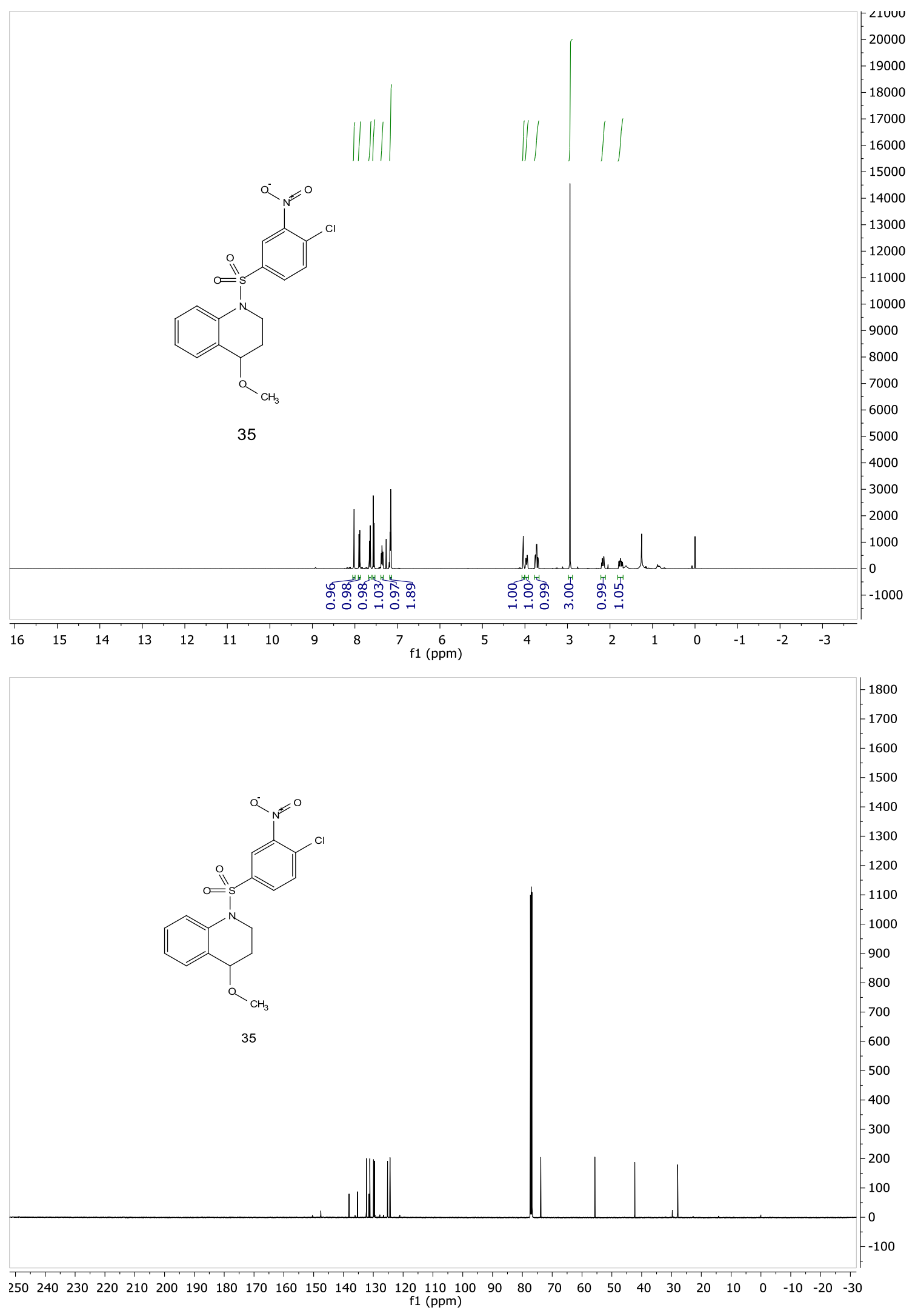



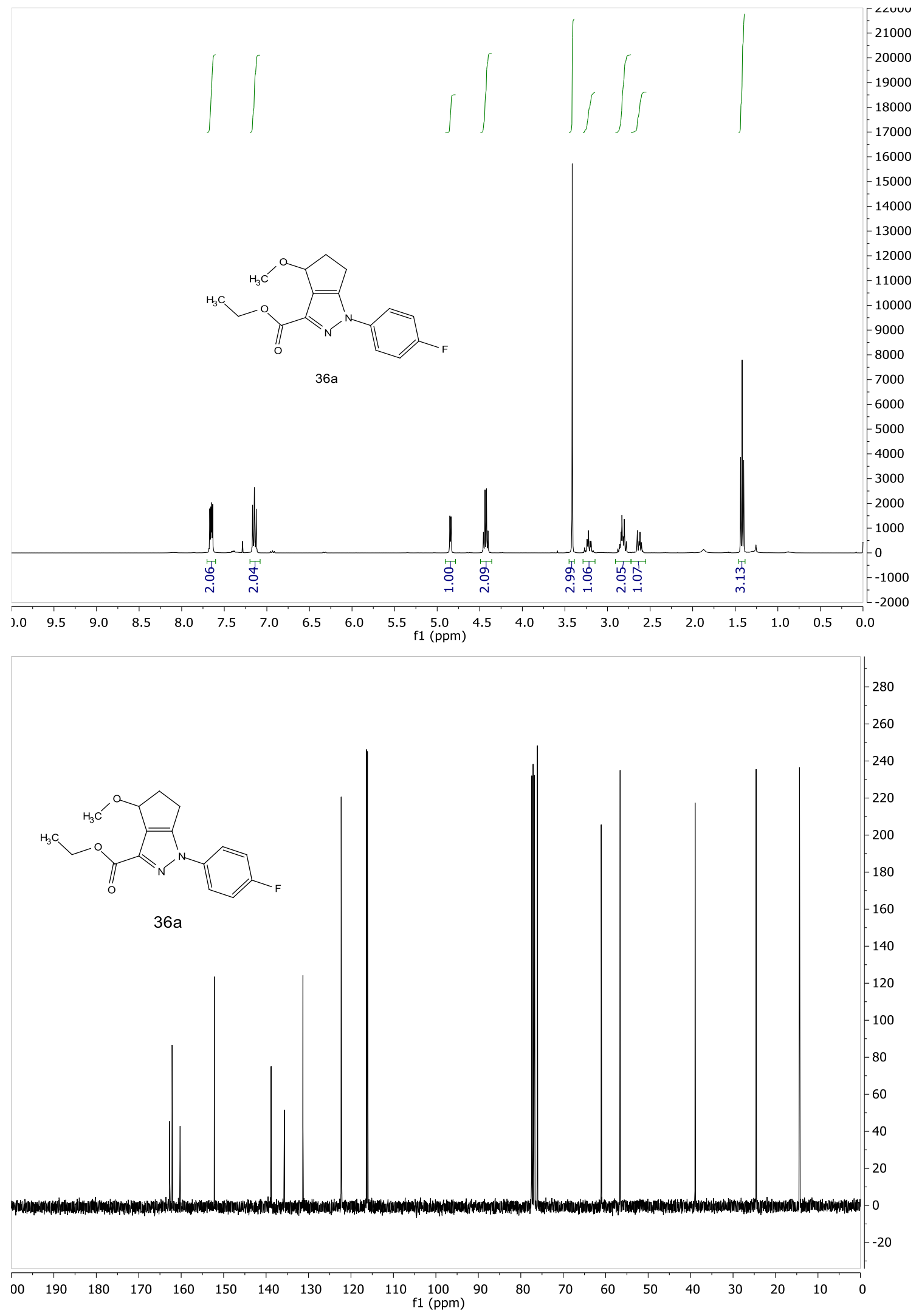


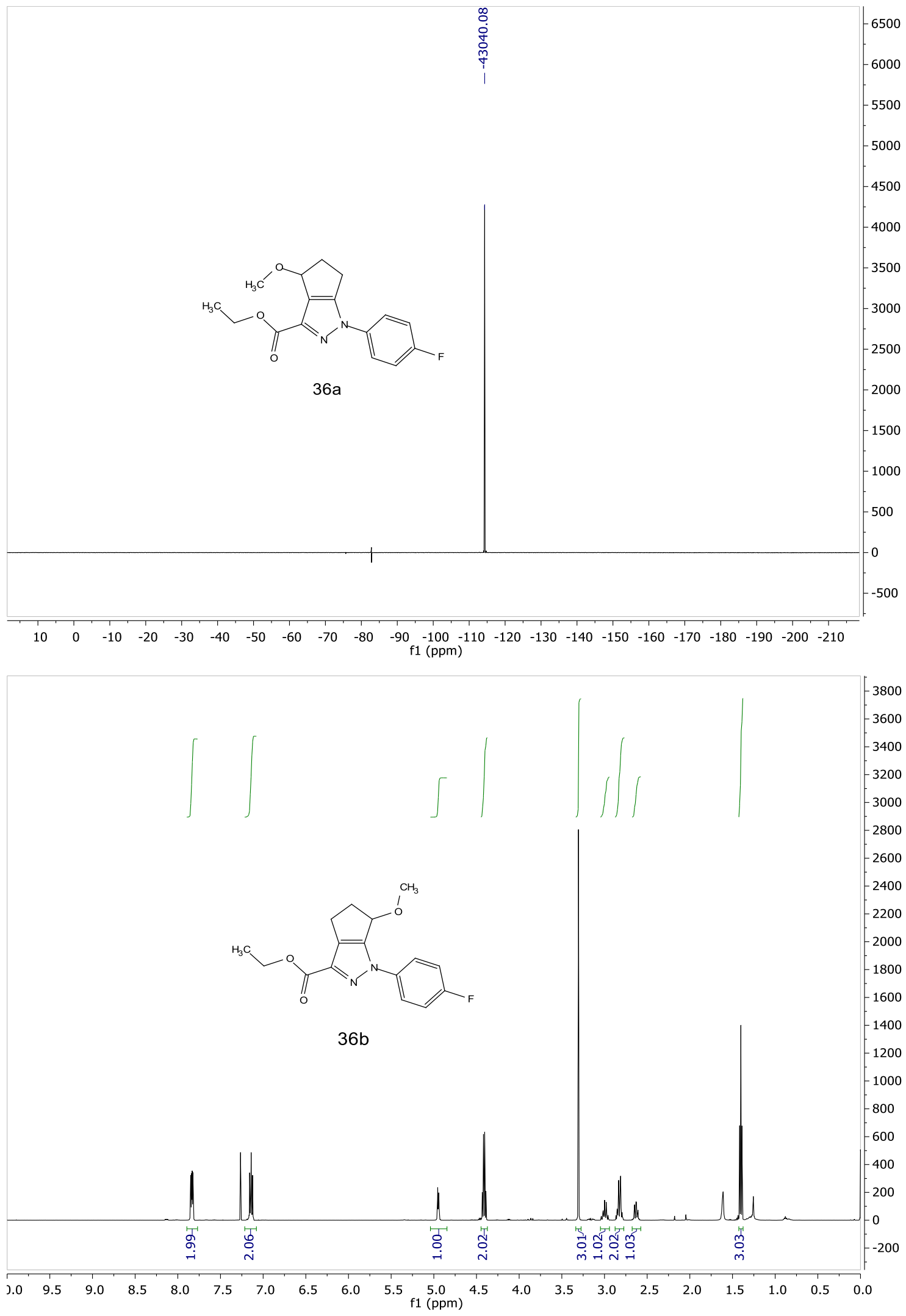



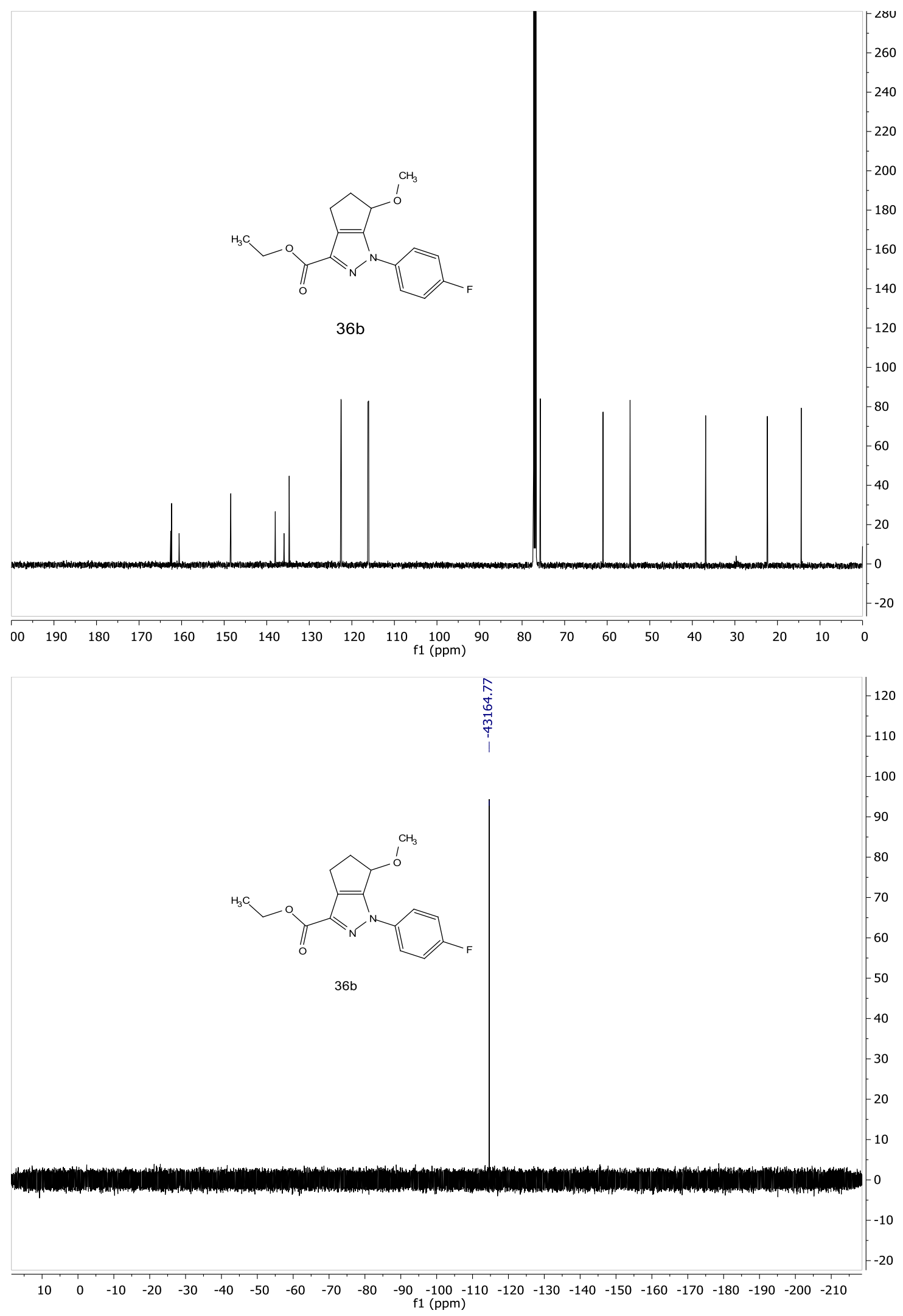

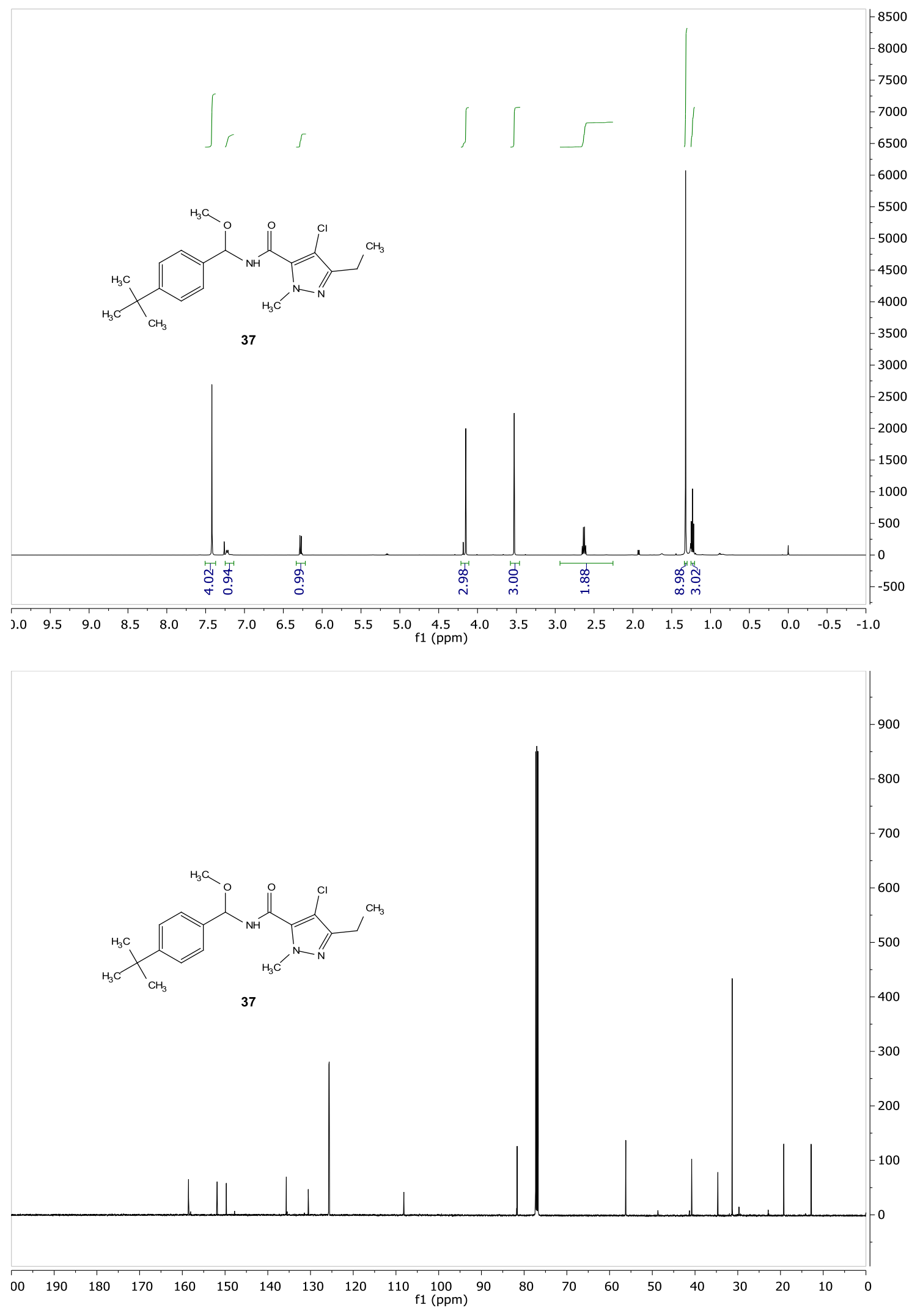


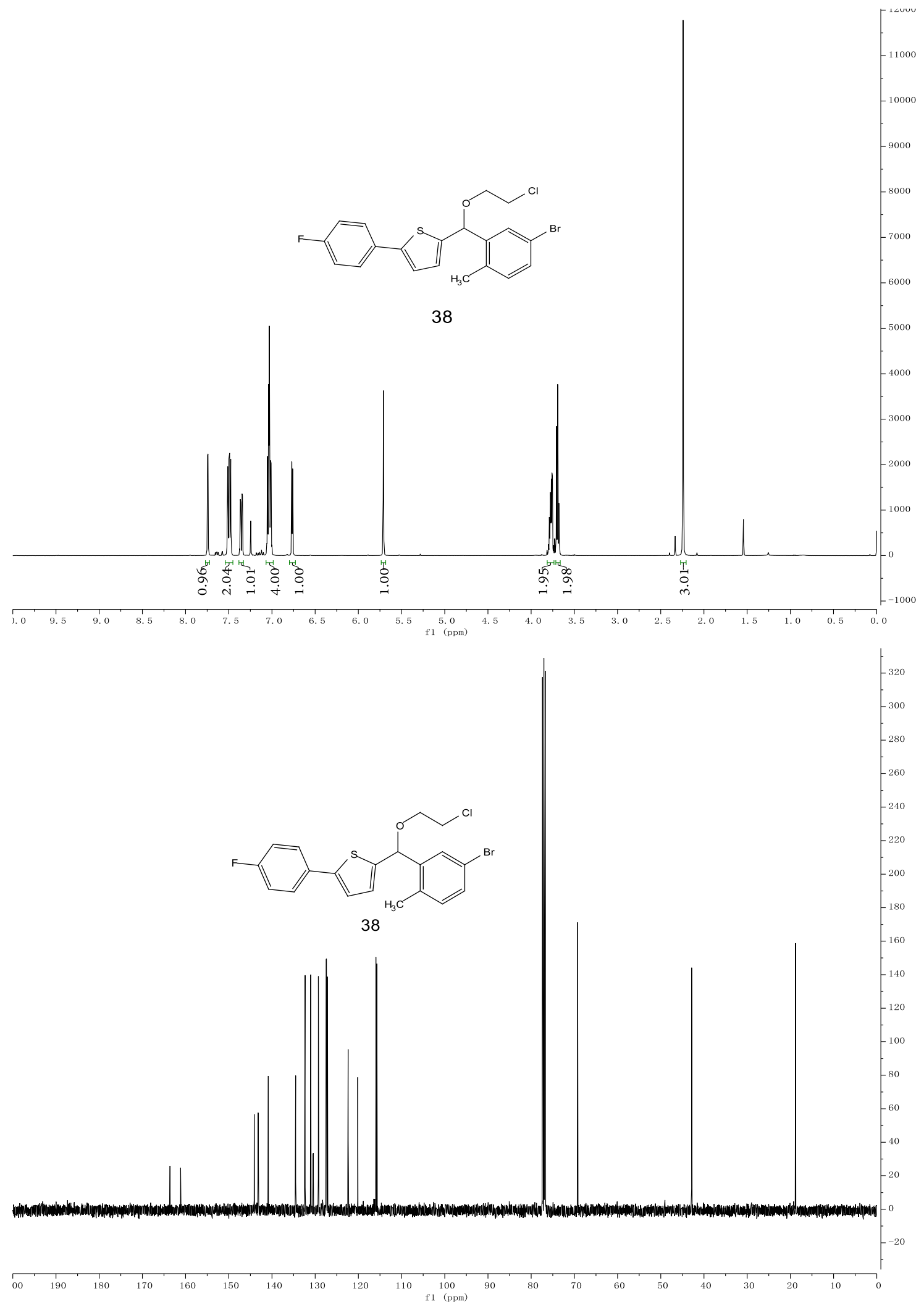

S69 


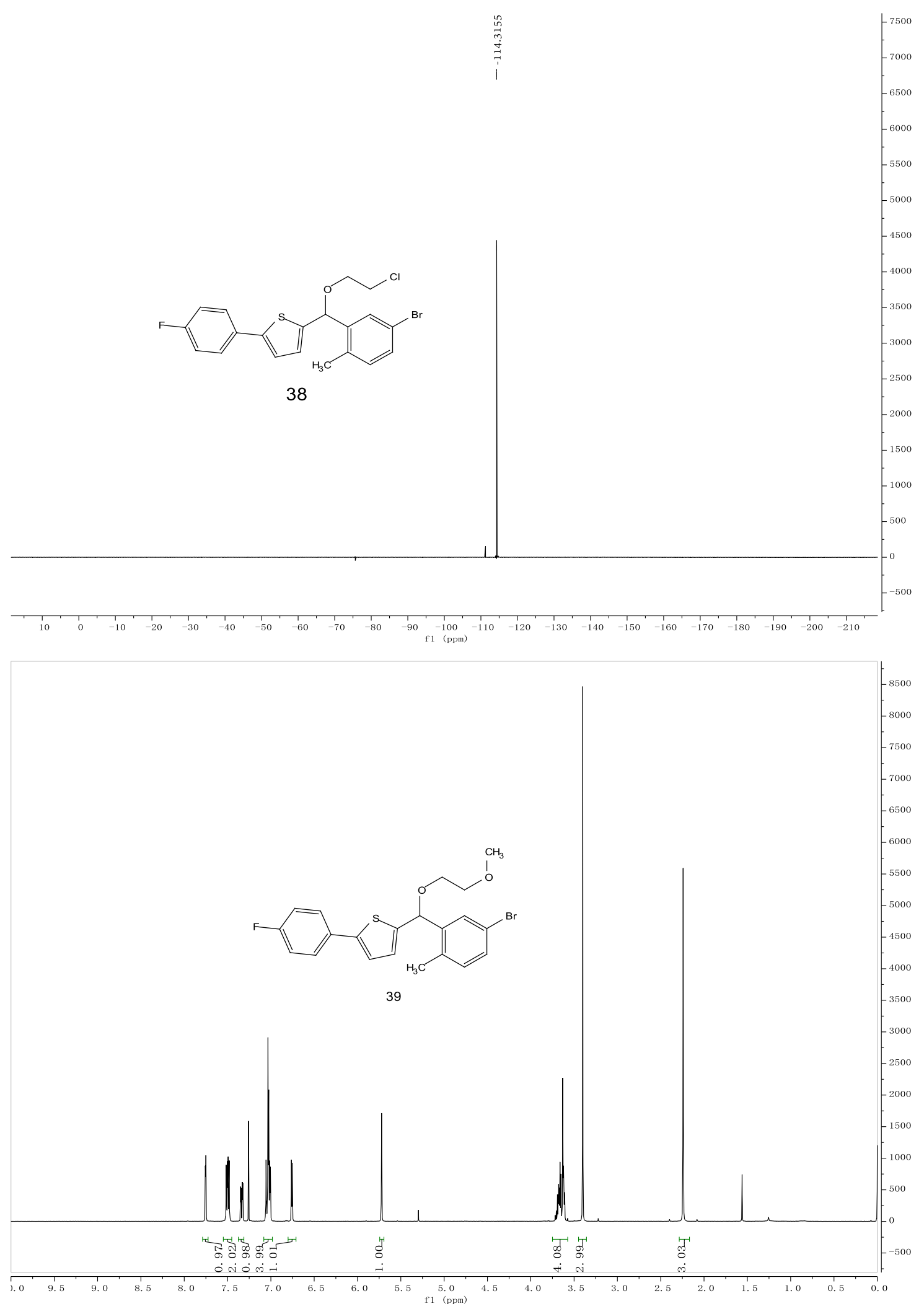




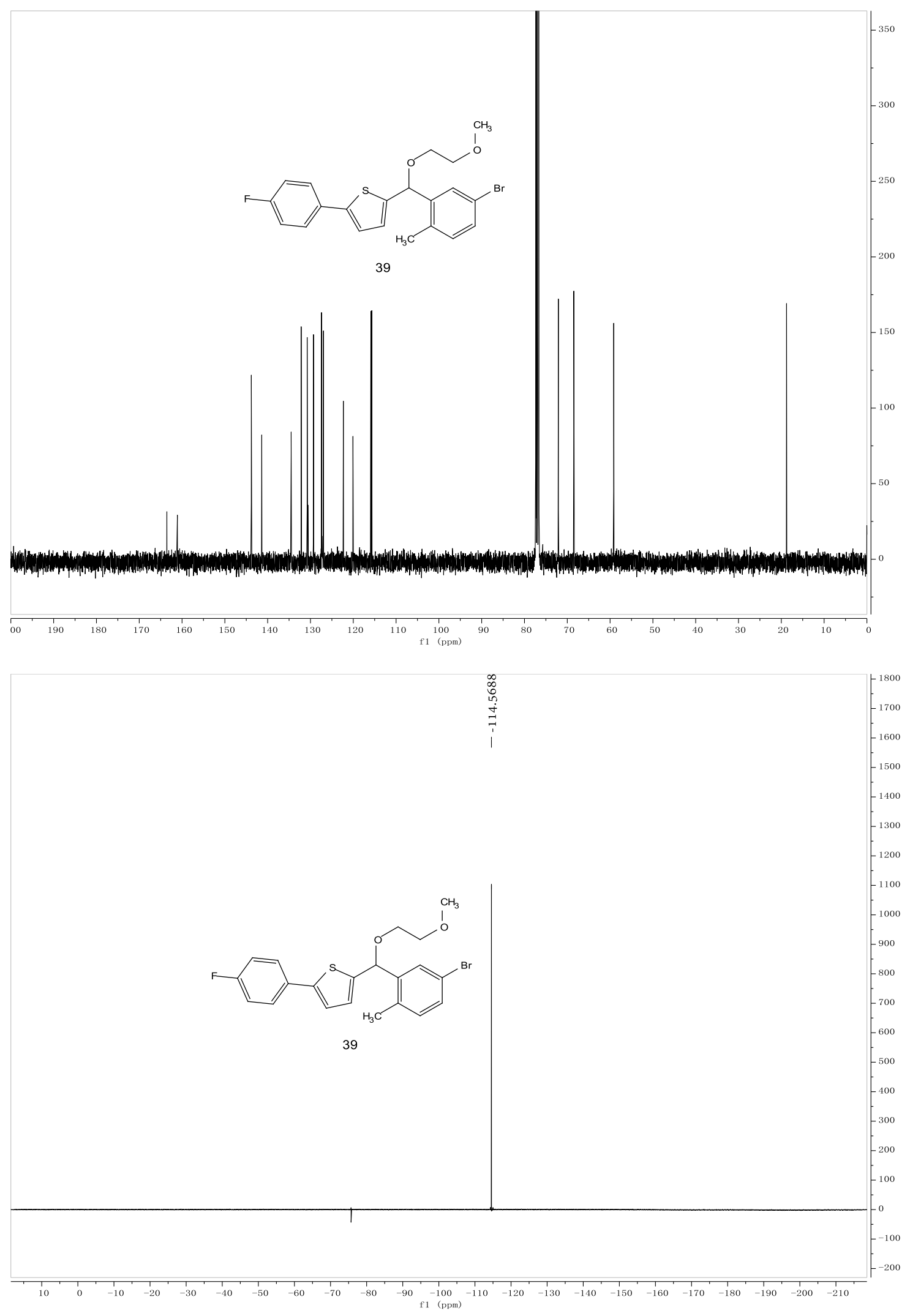




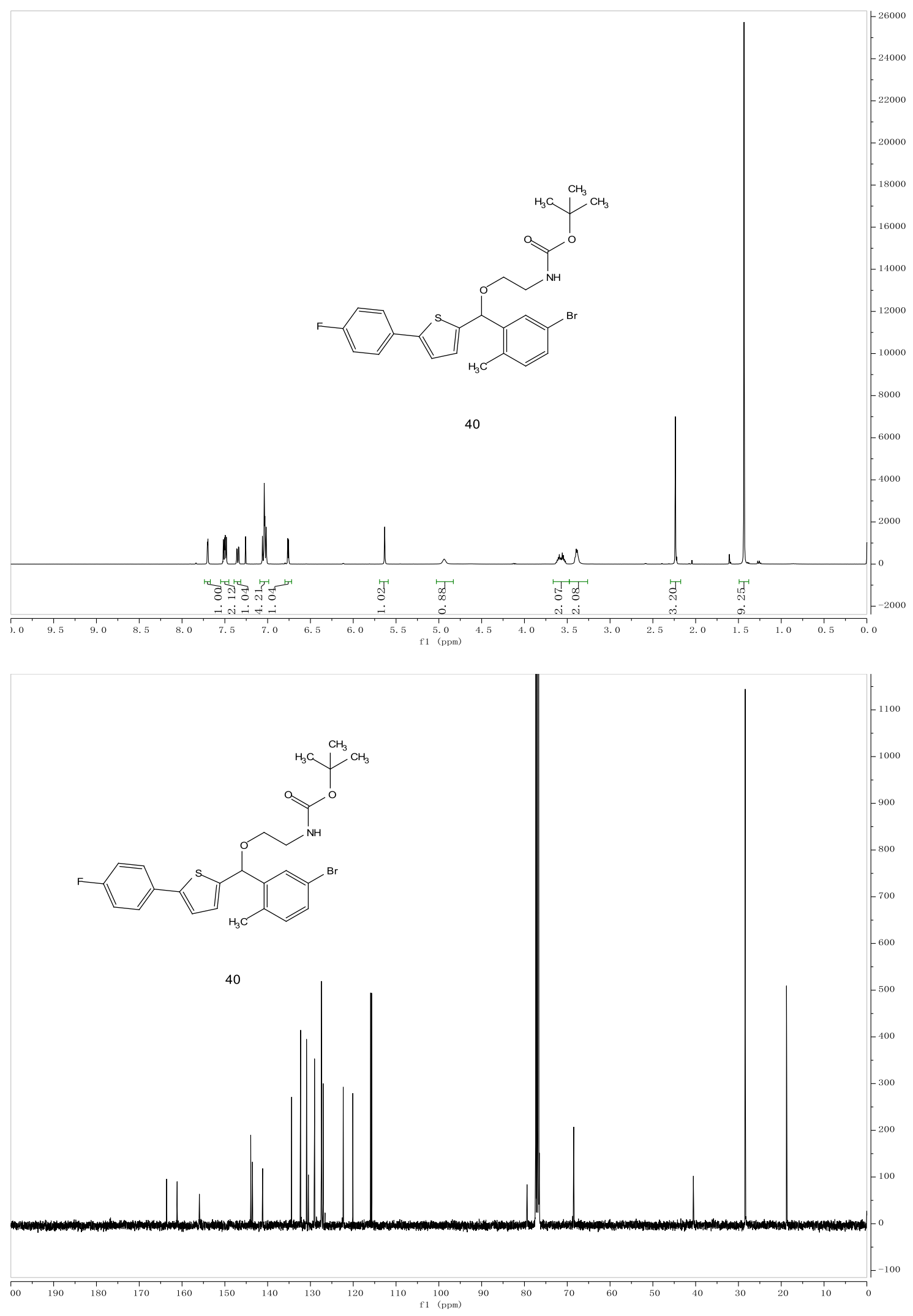



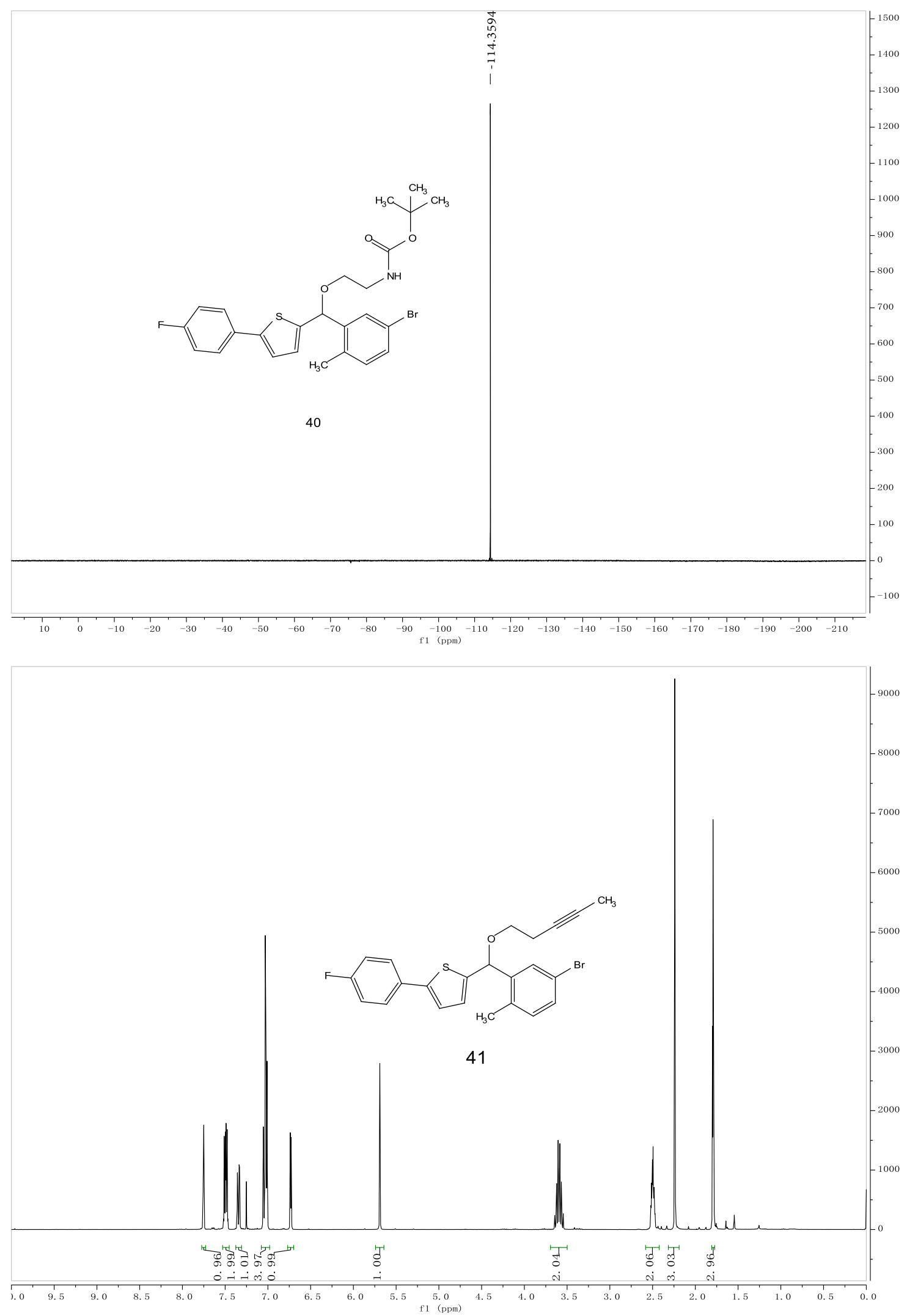


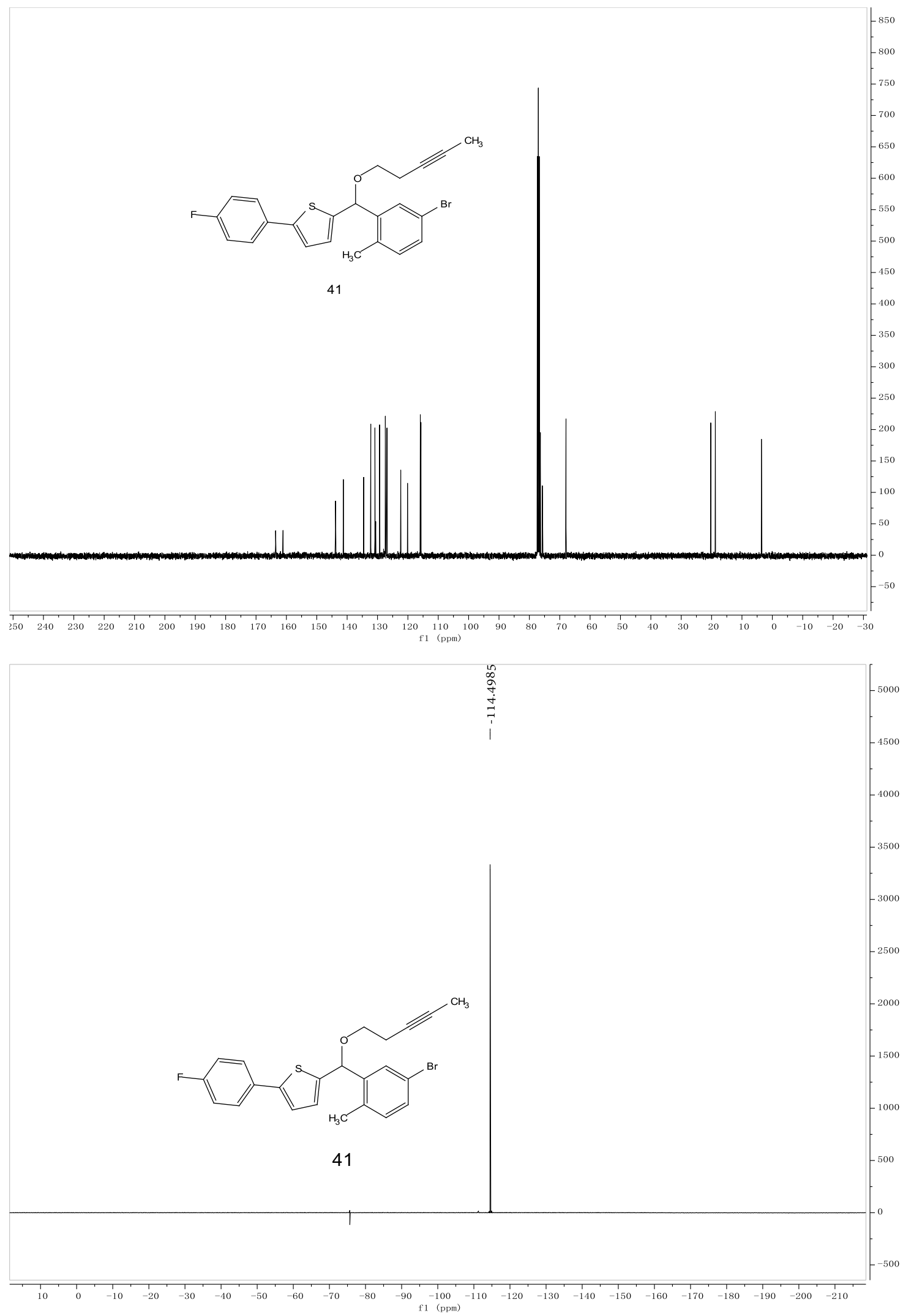




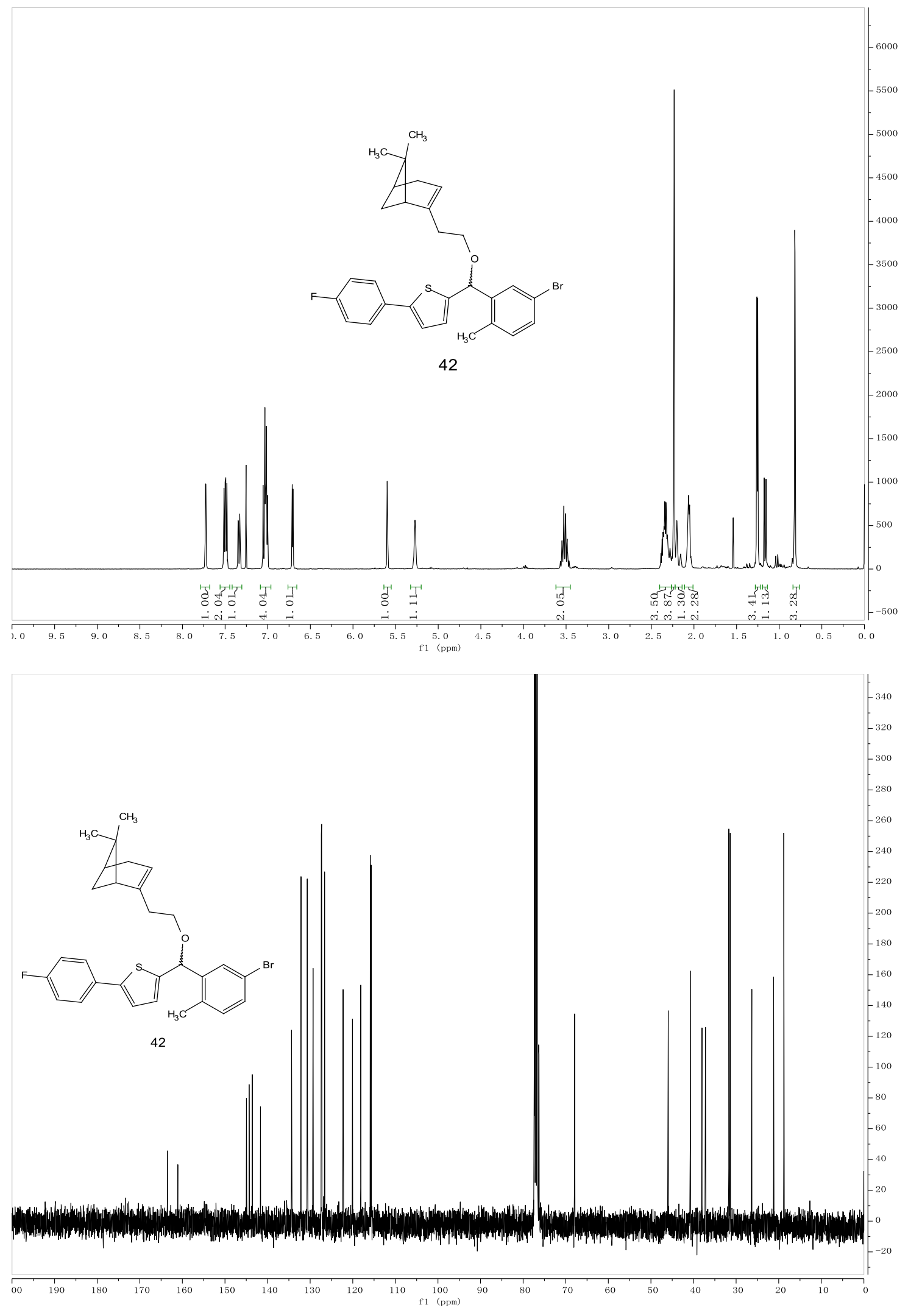



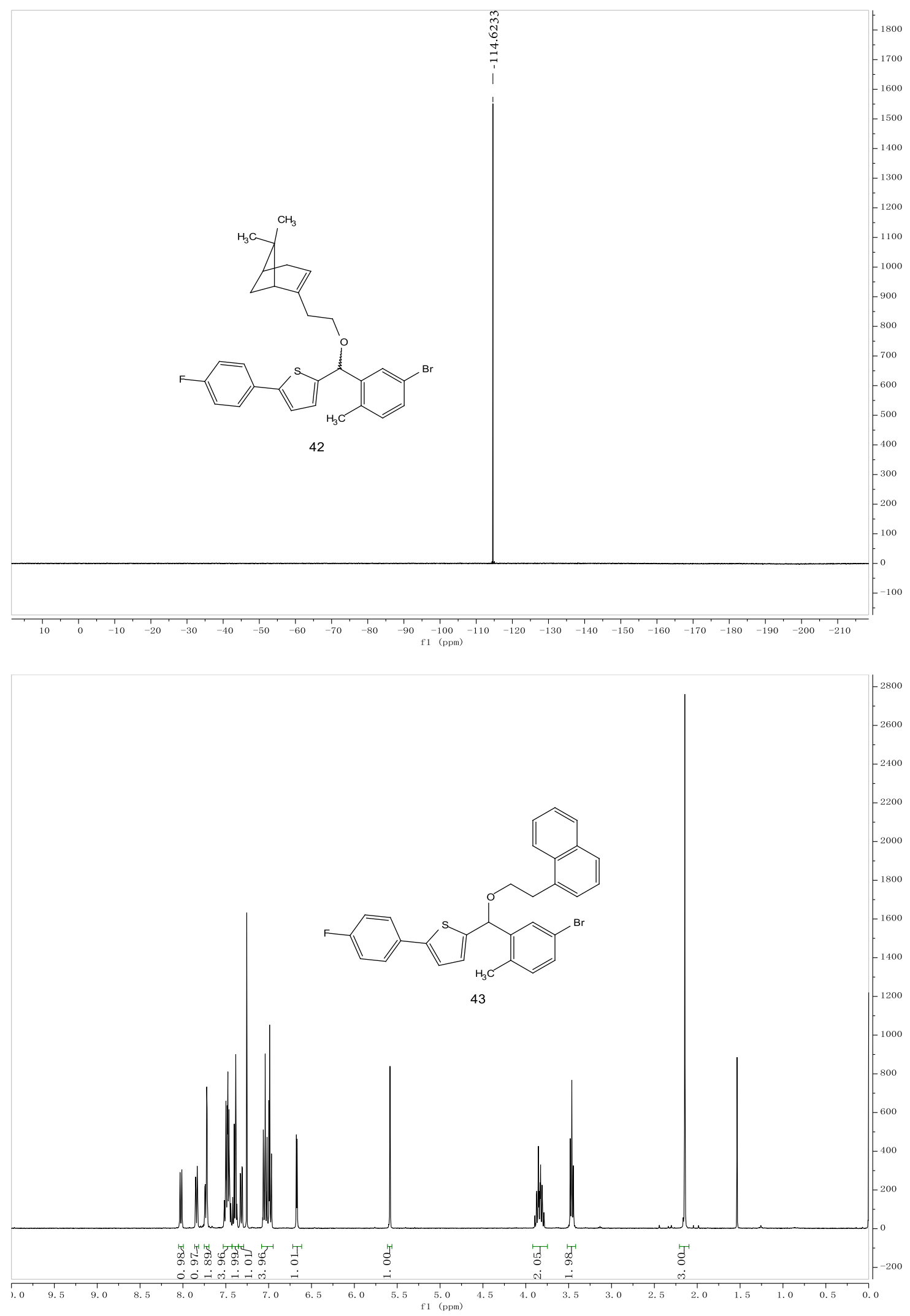

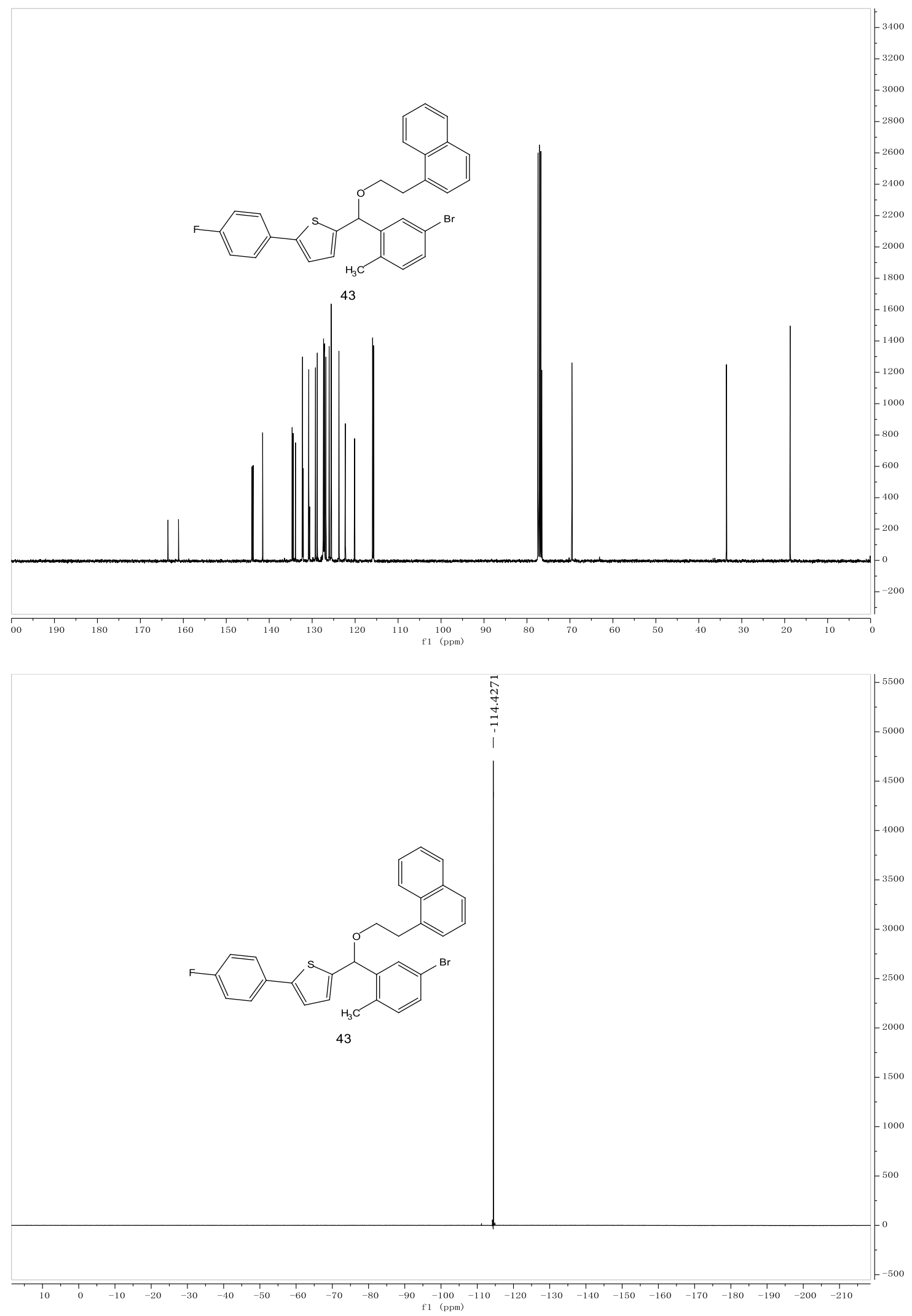

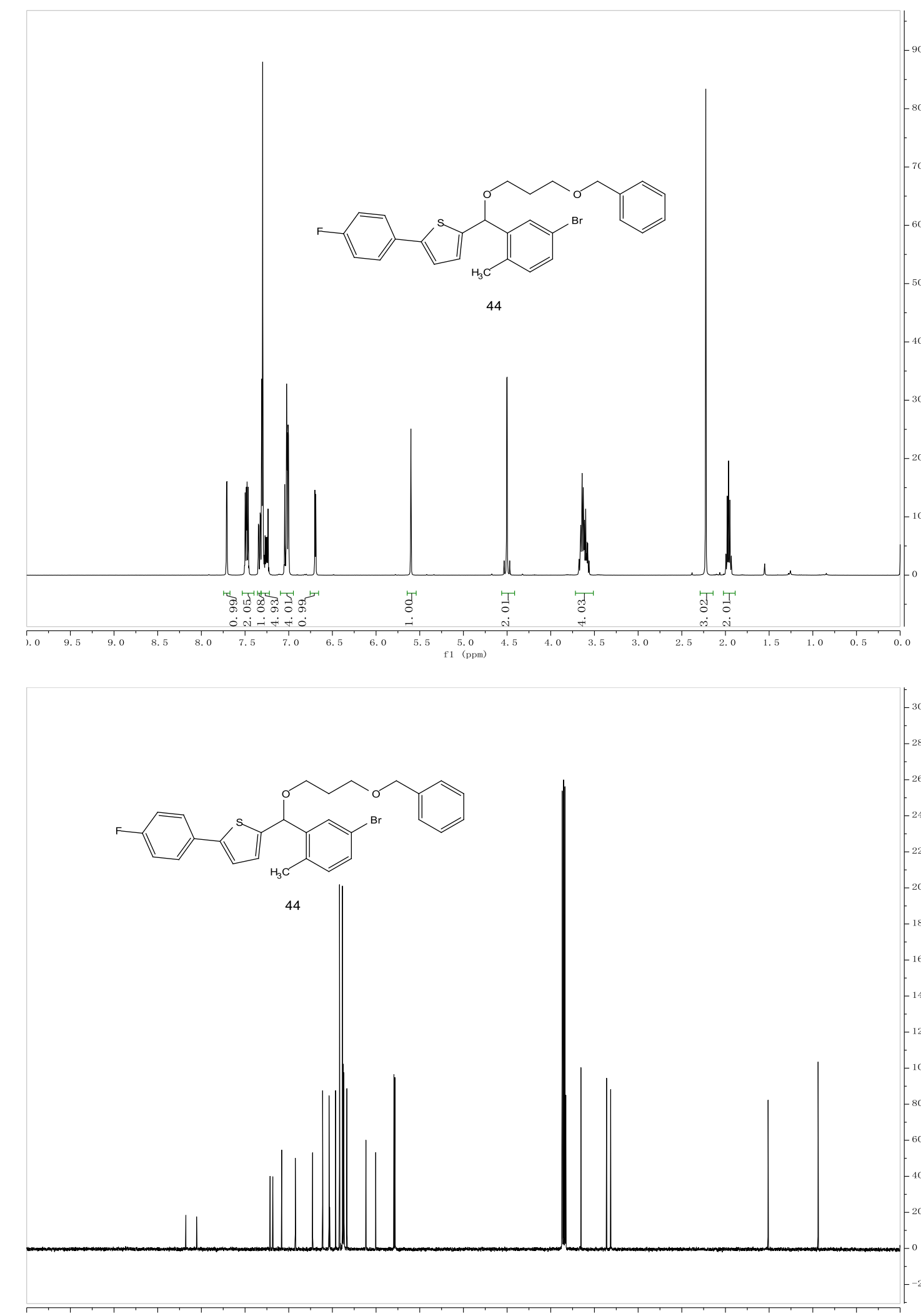


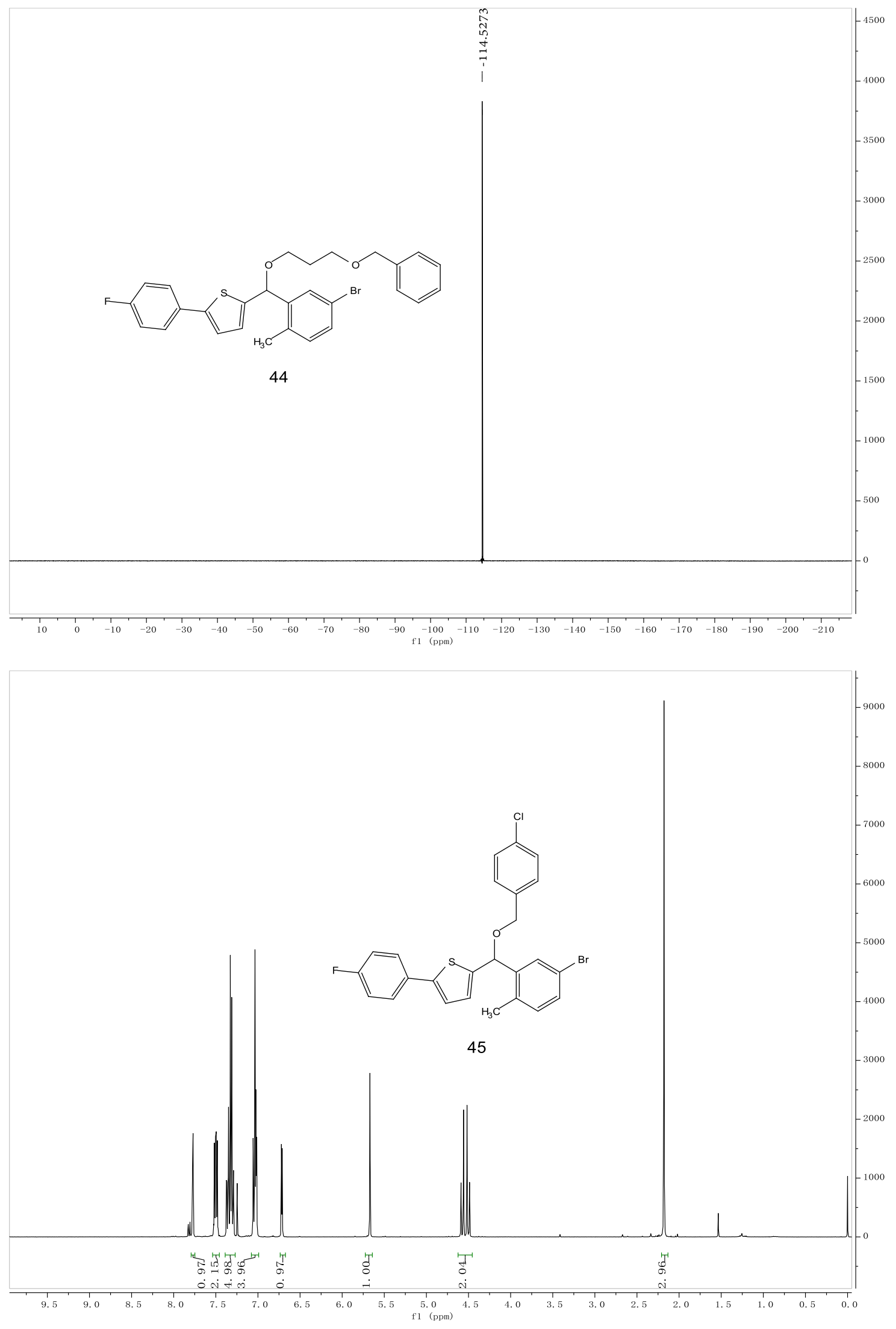




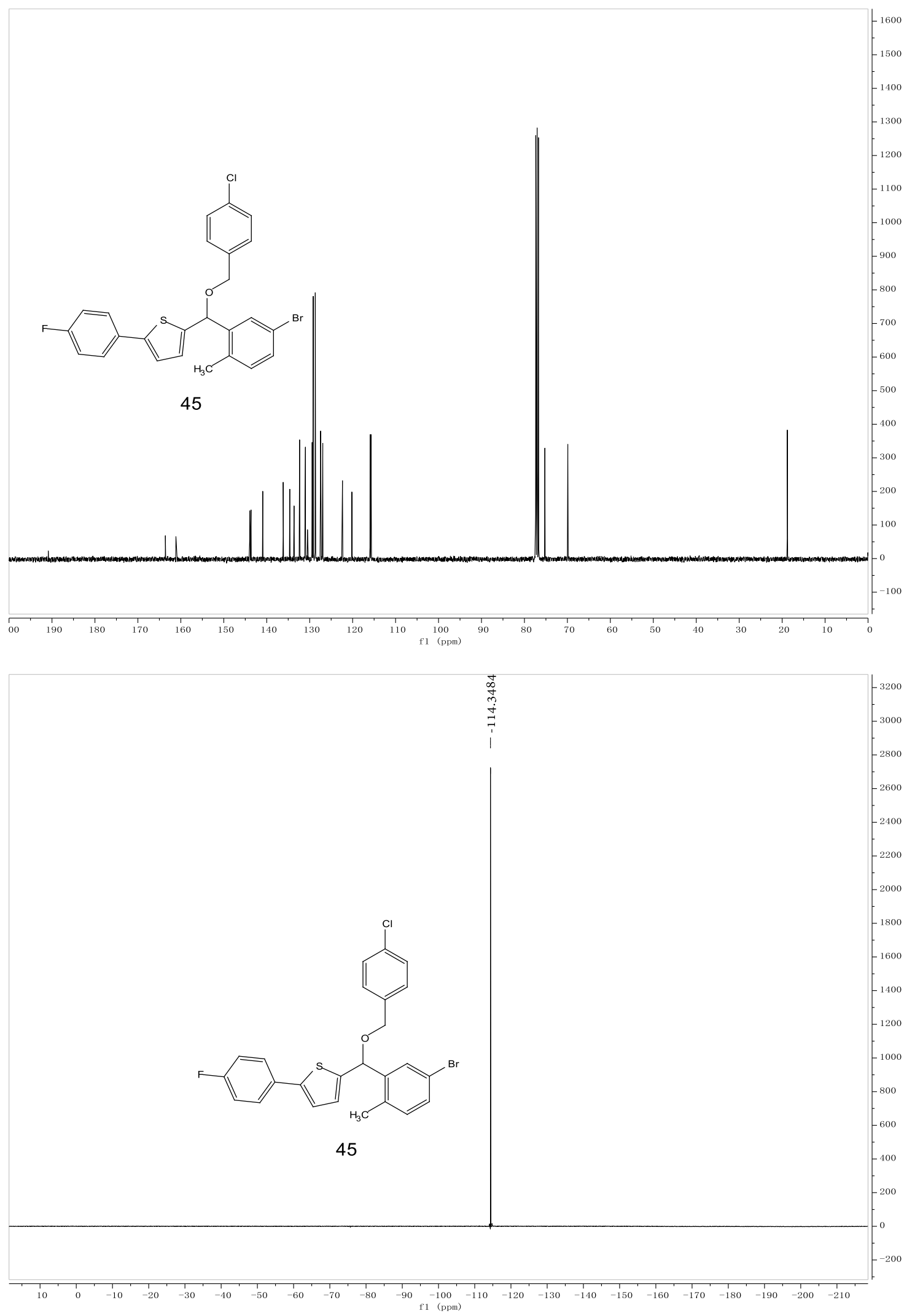



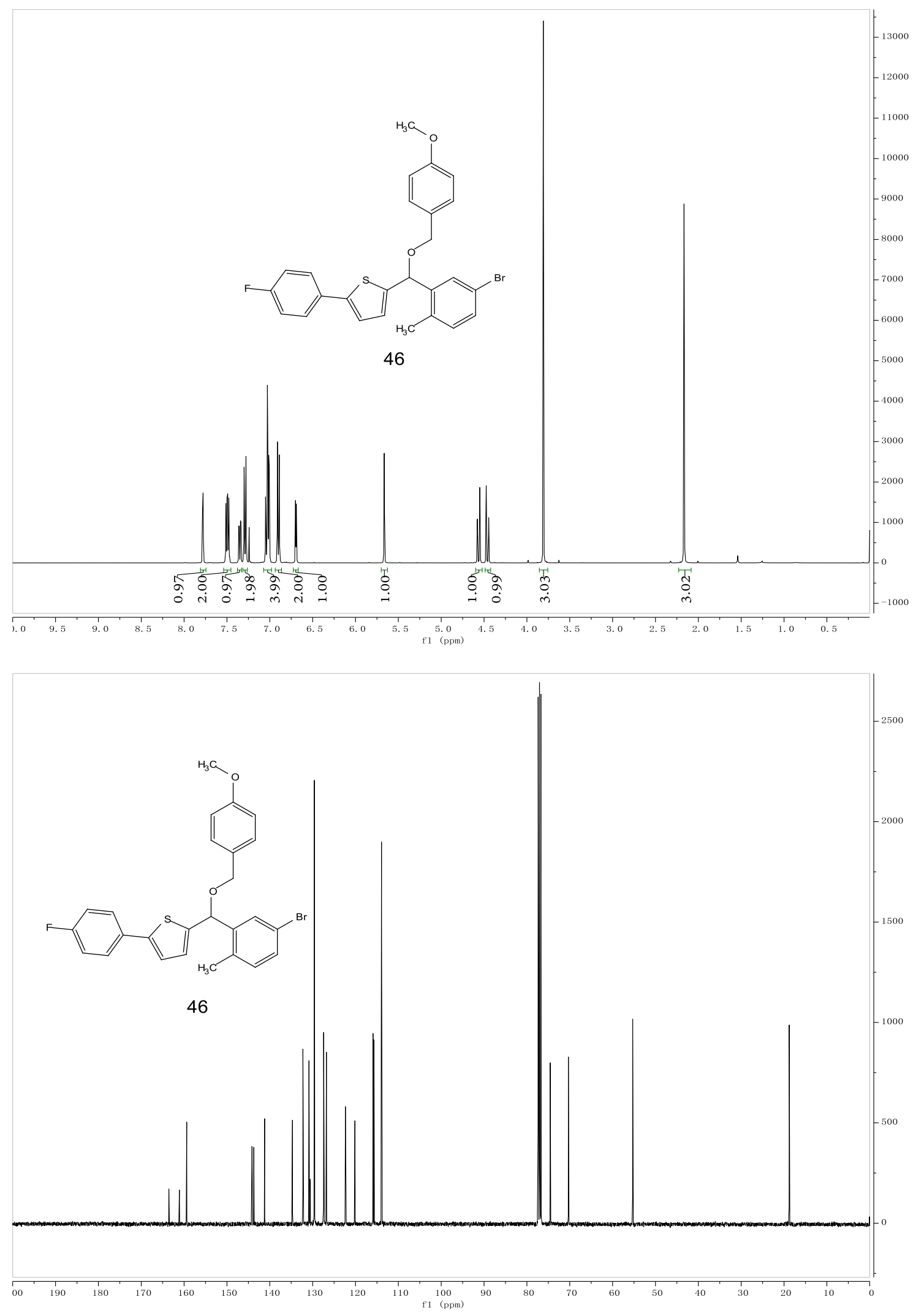

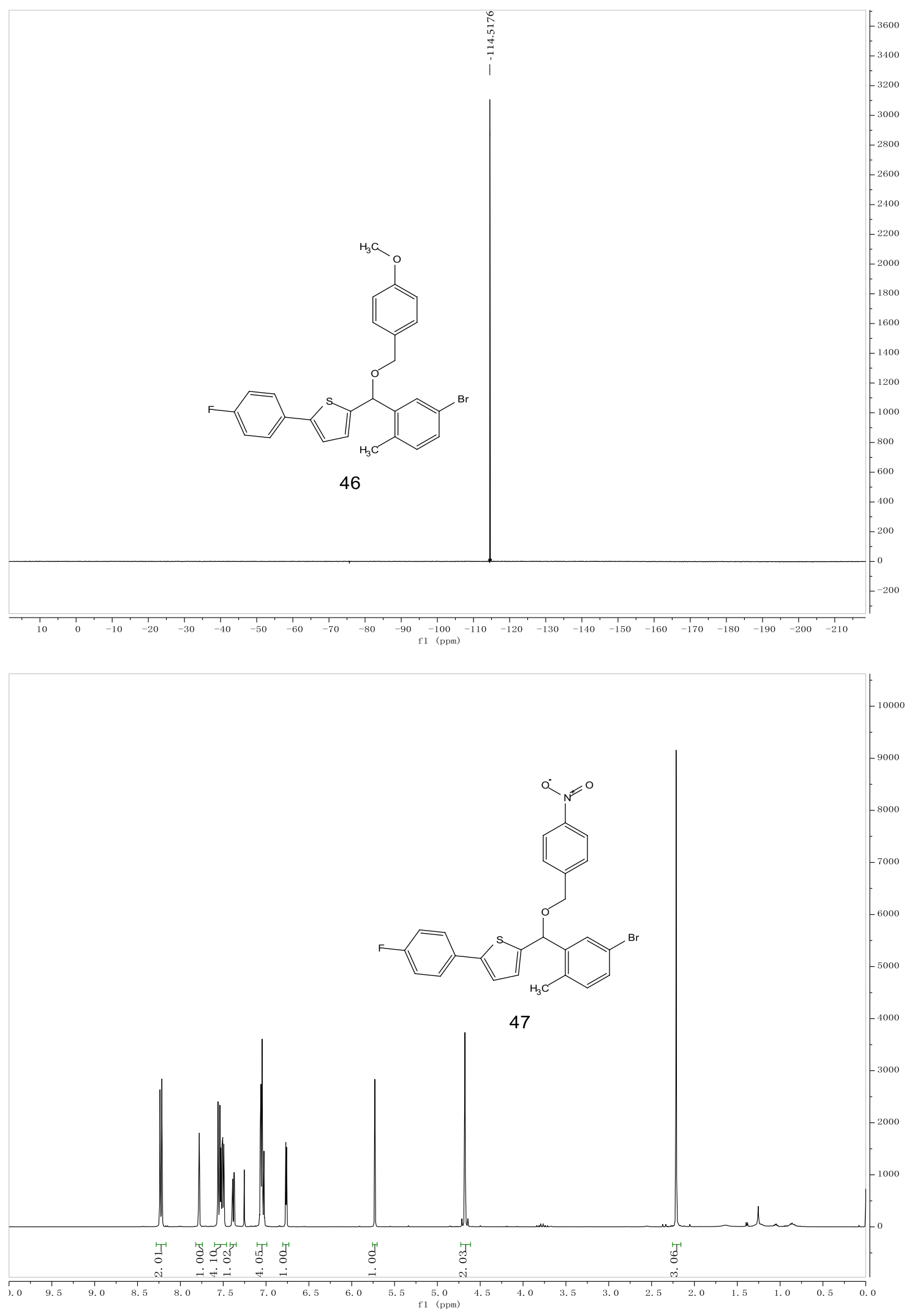


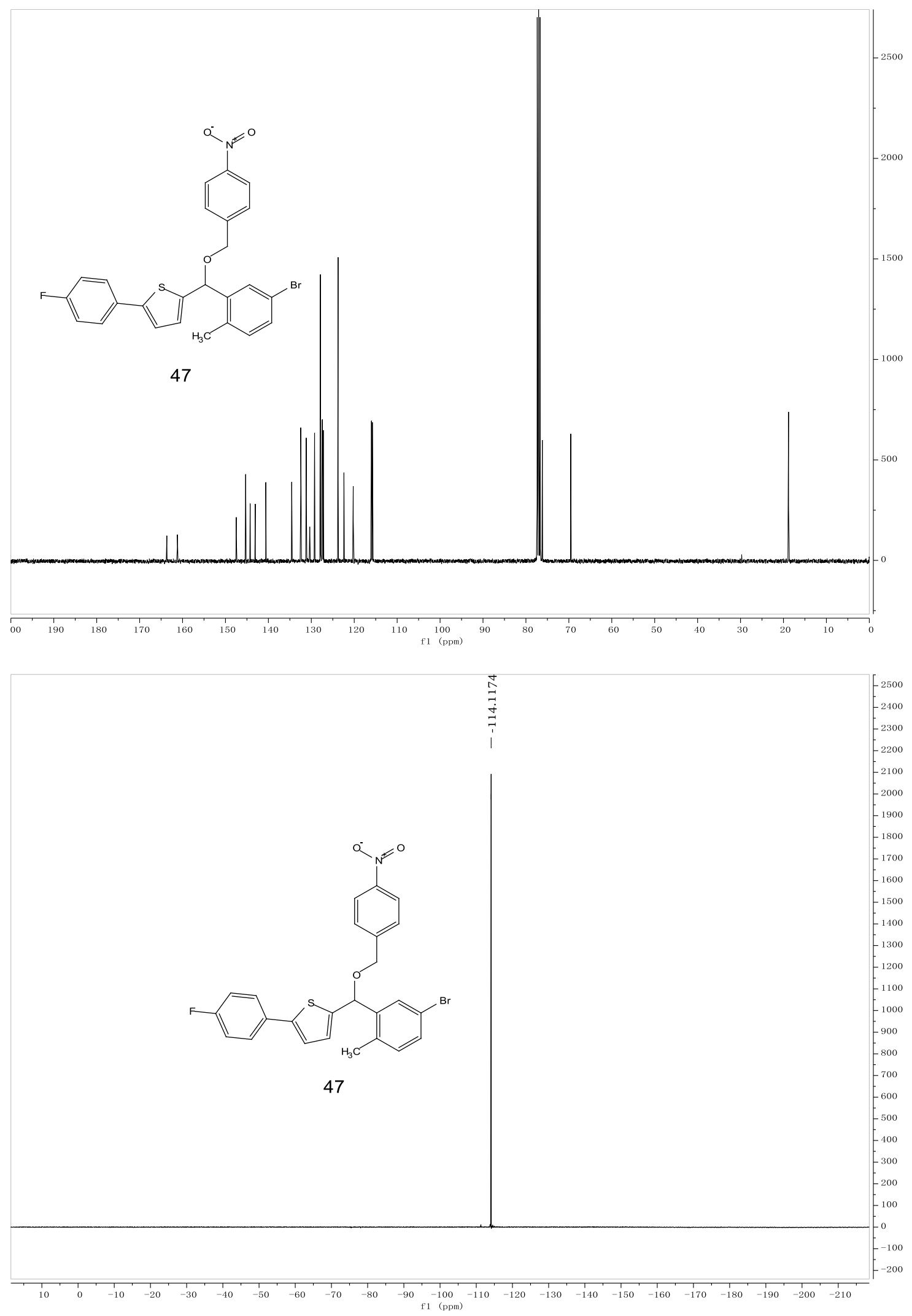




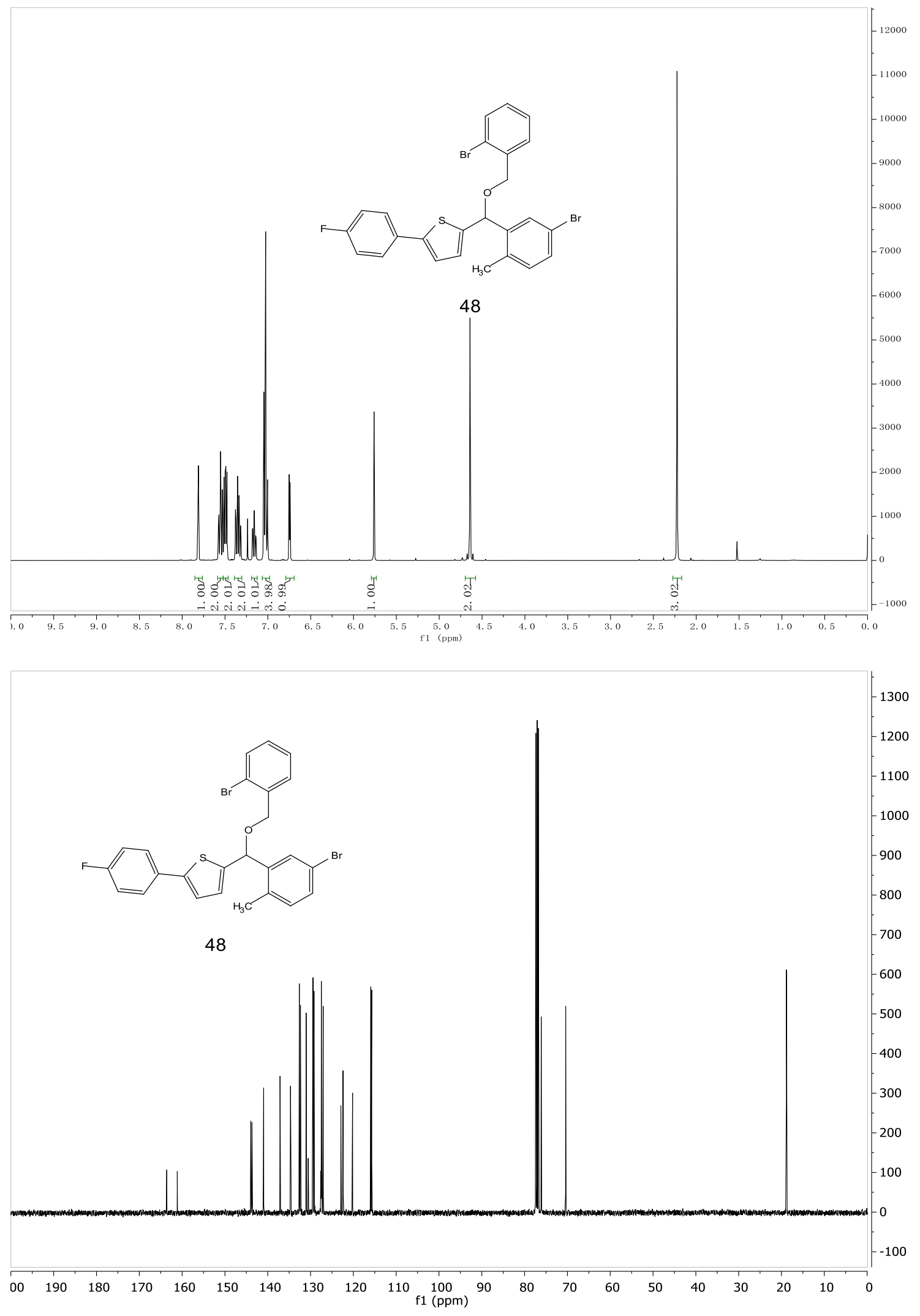



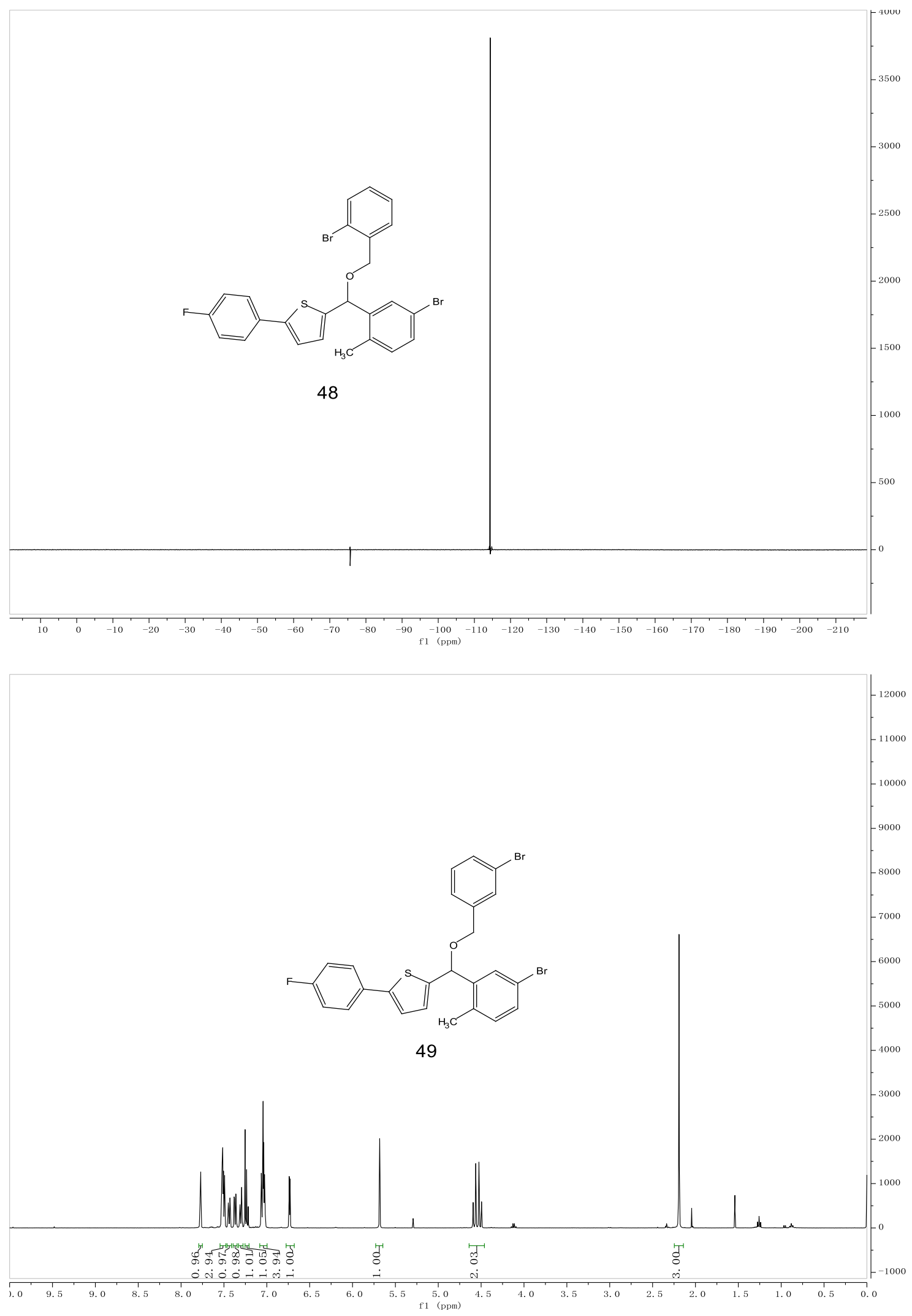


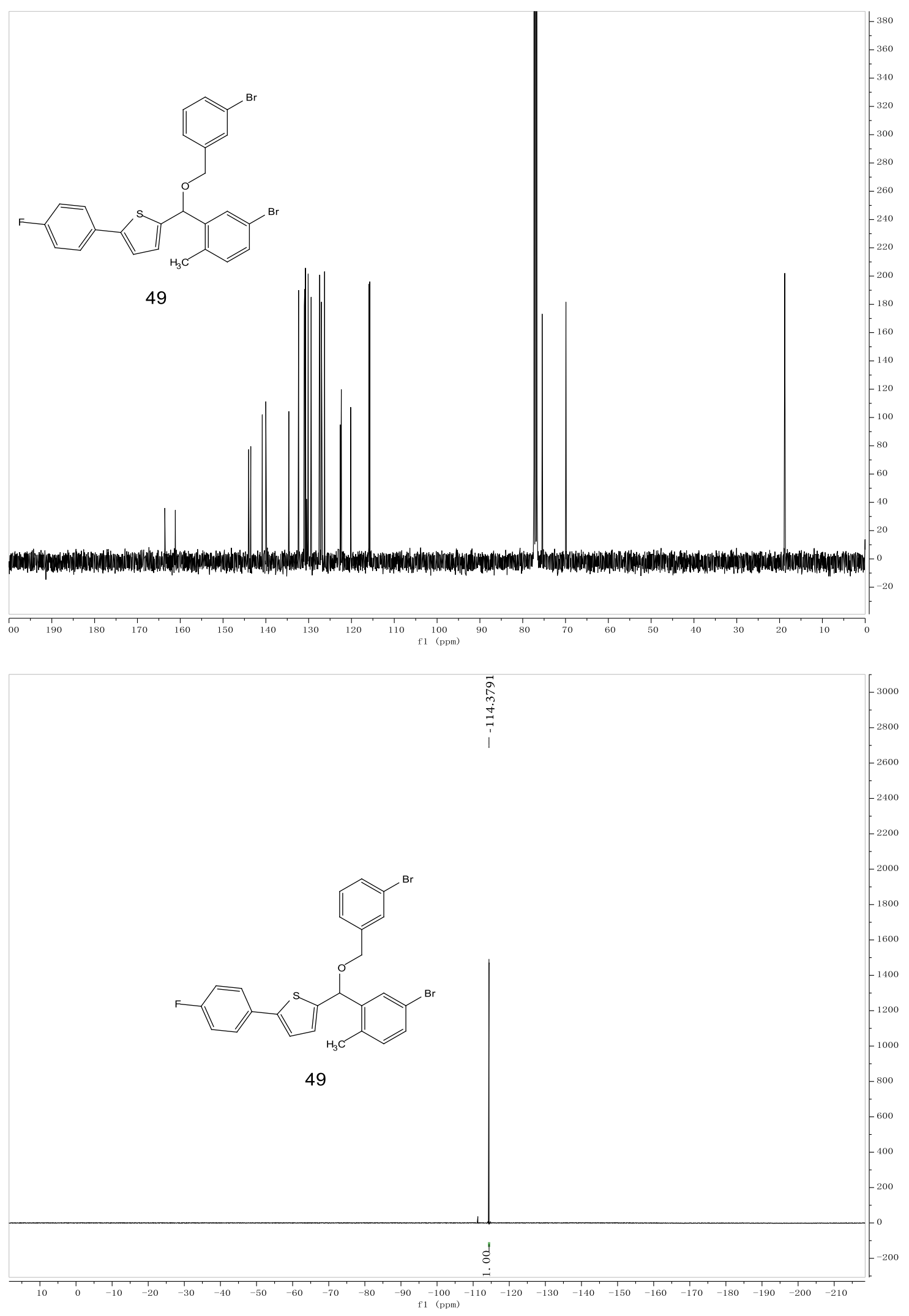




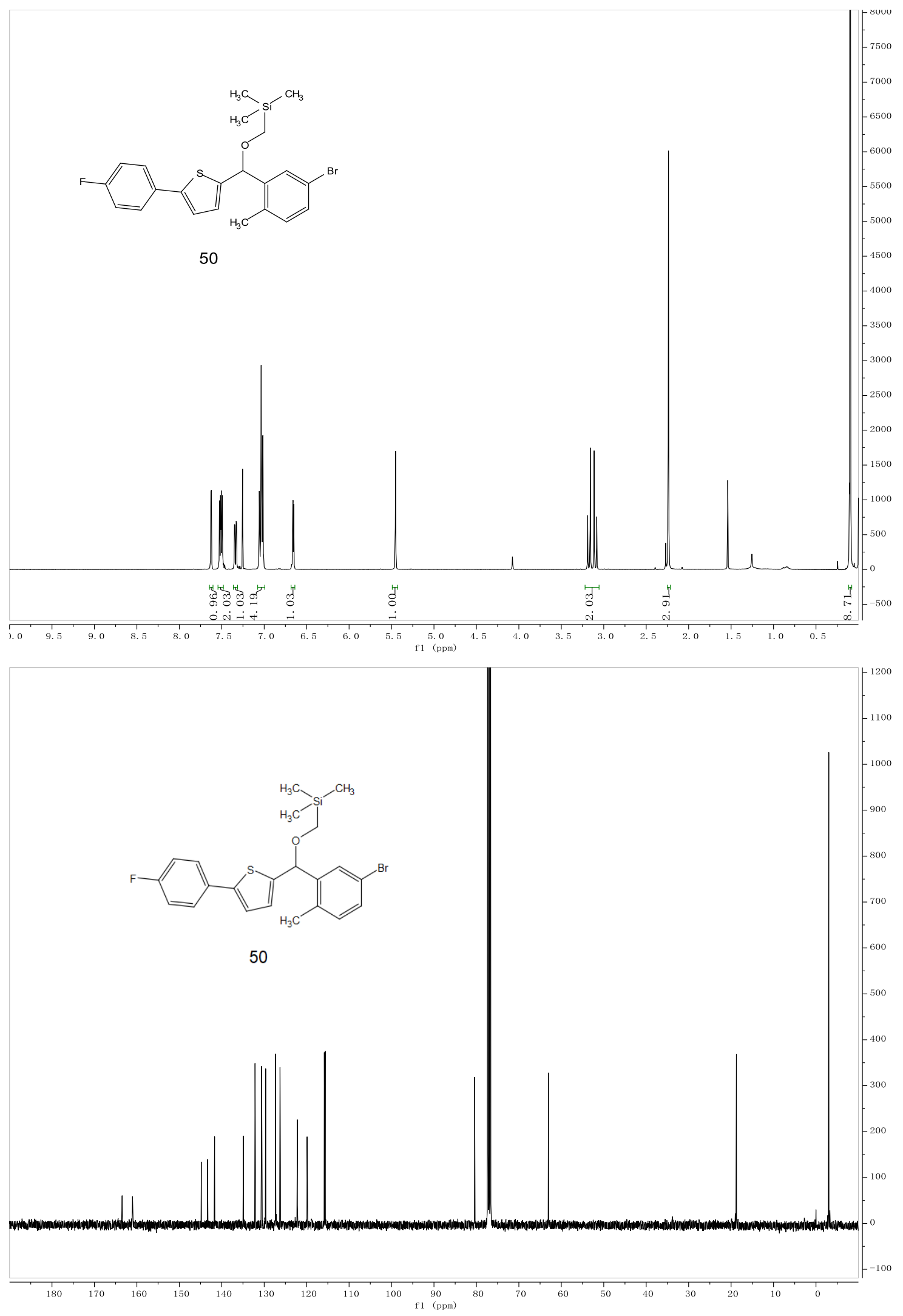



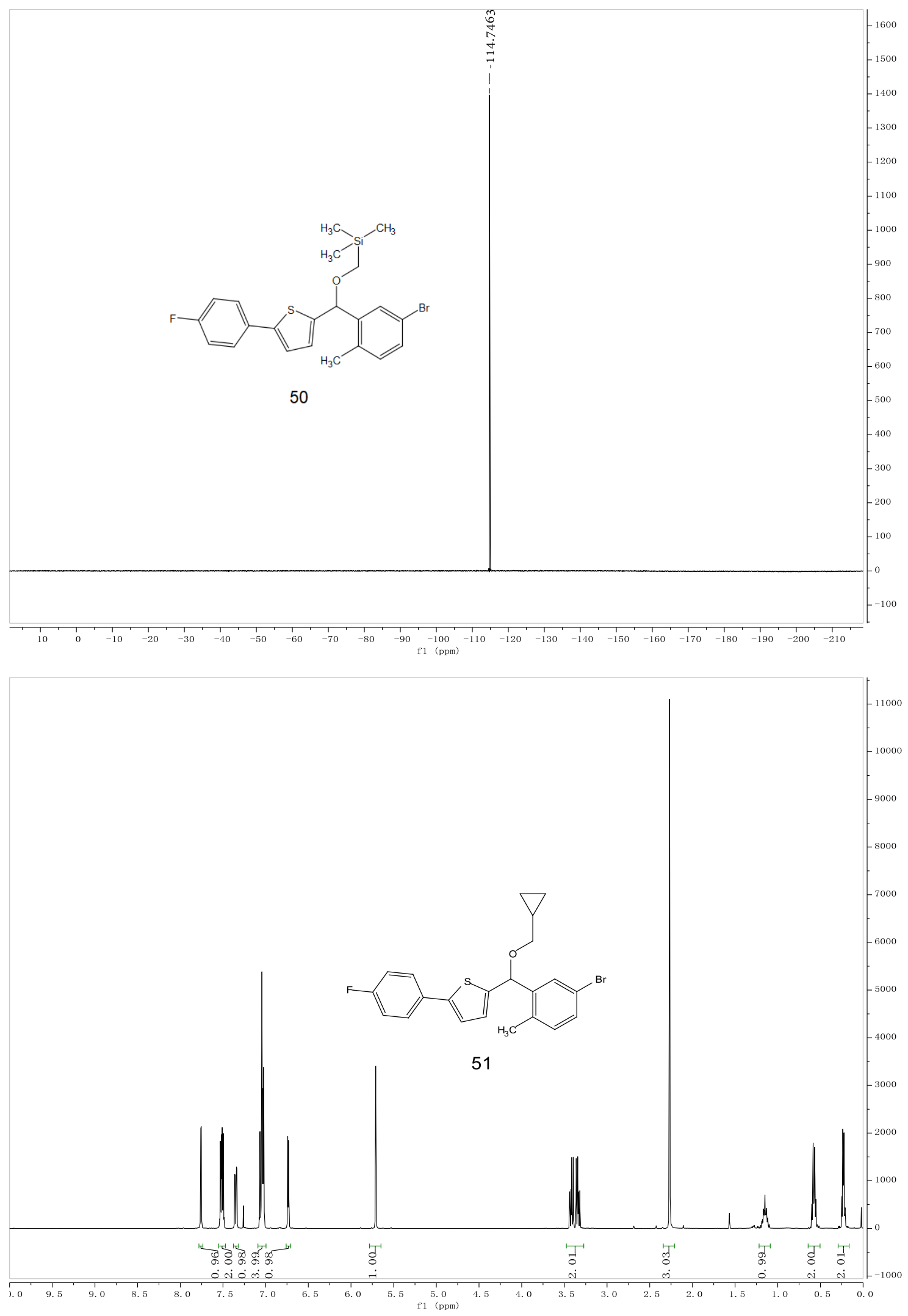

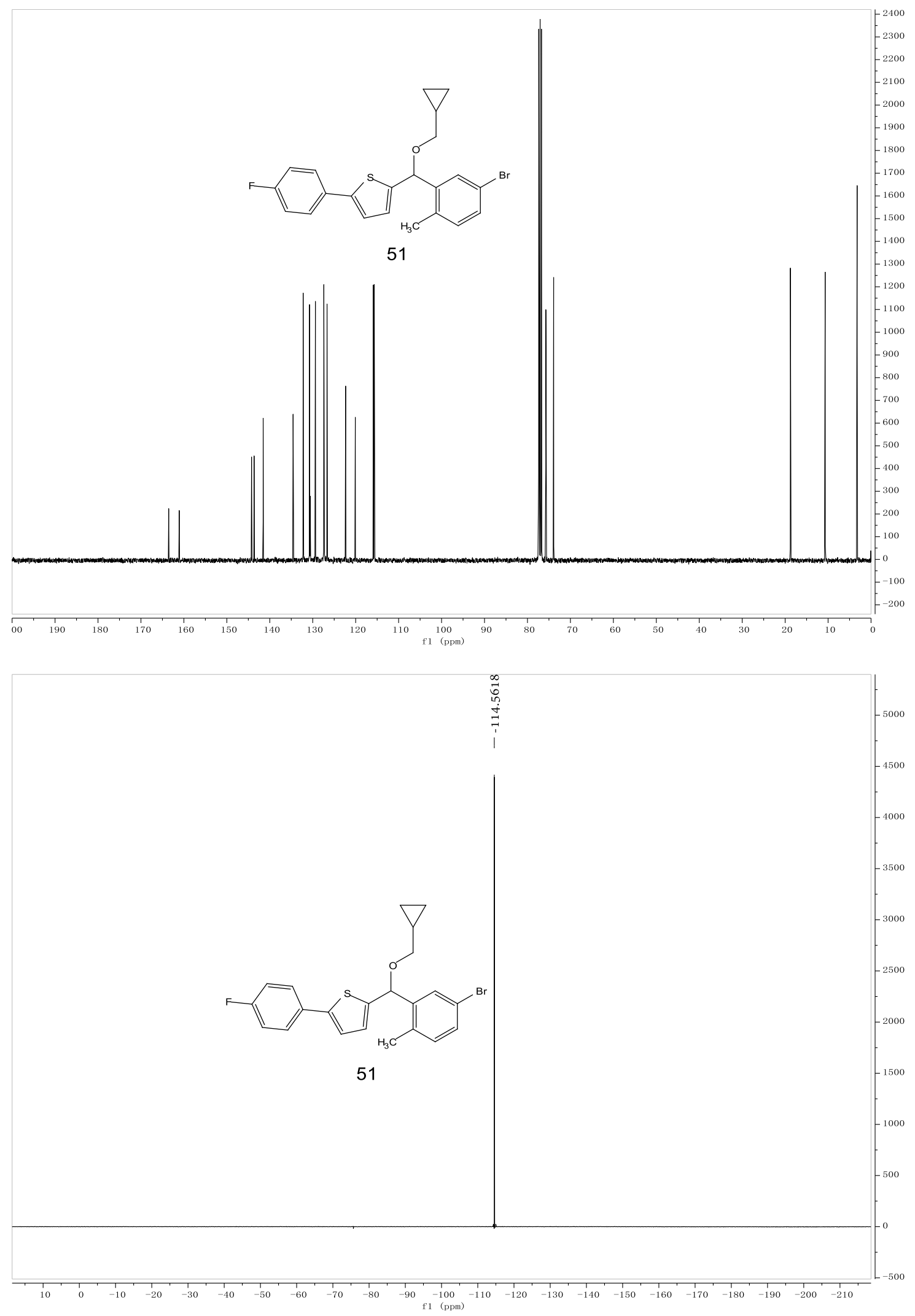


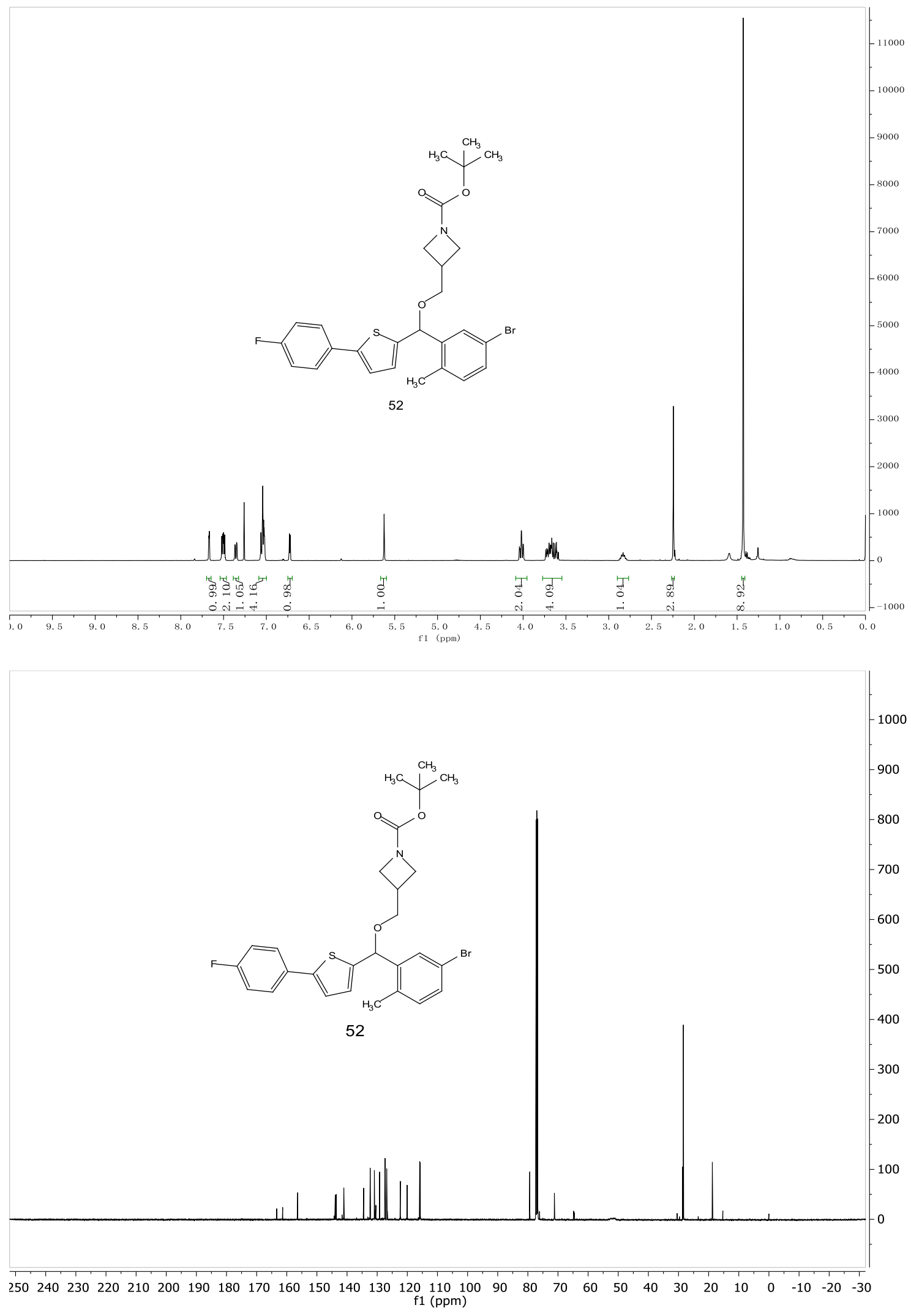



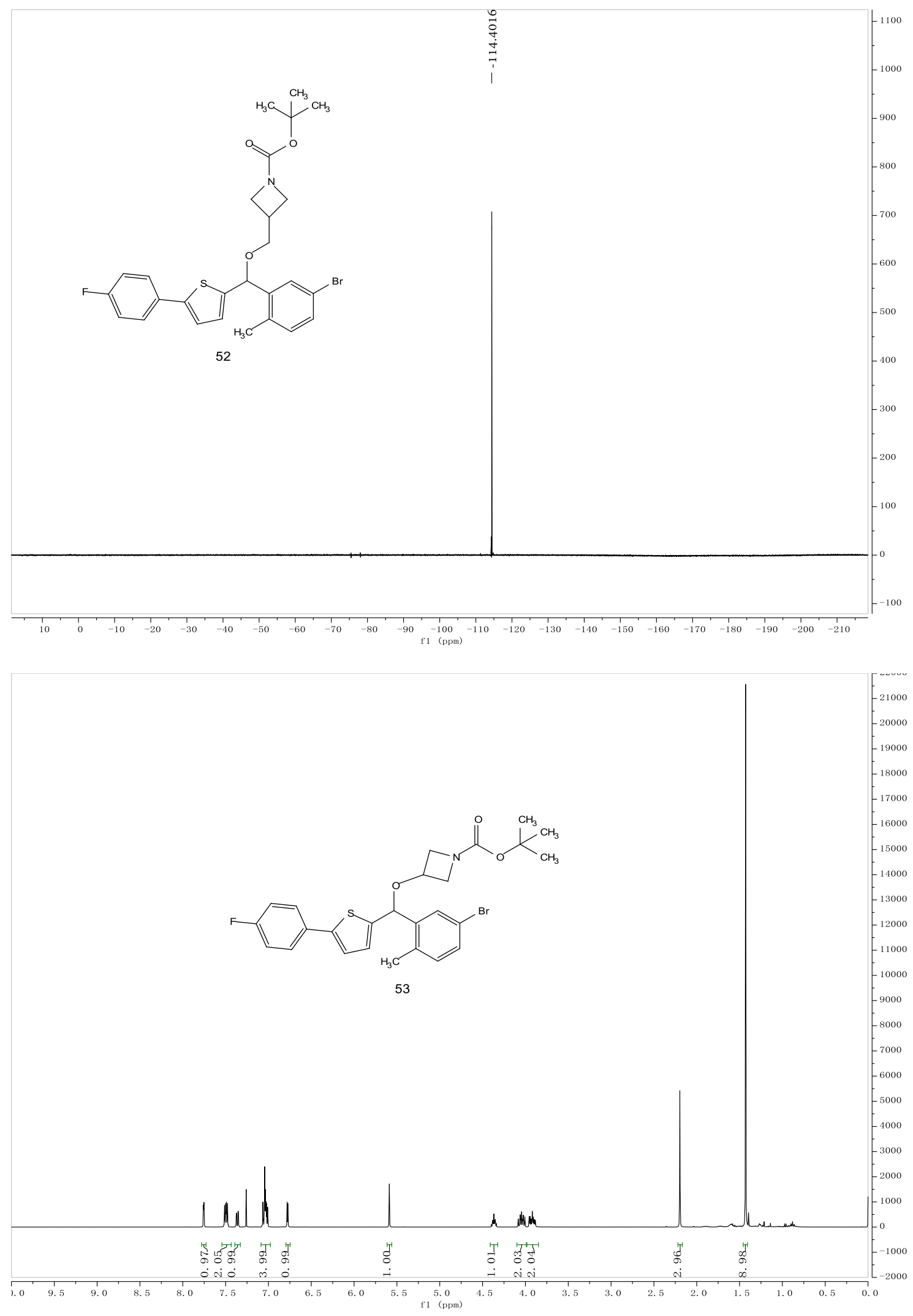


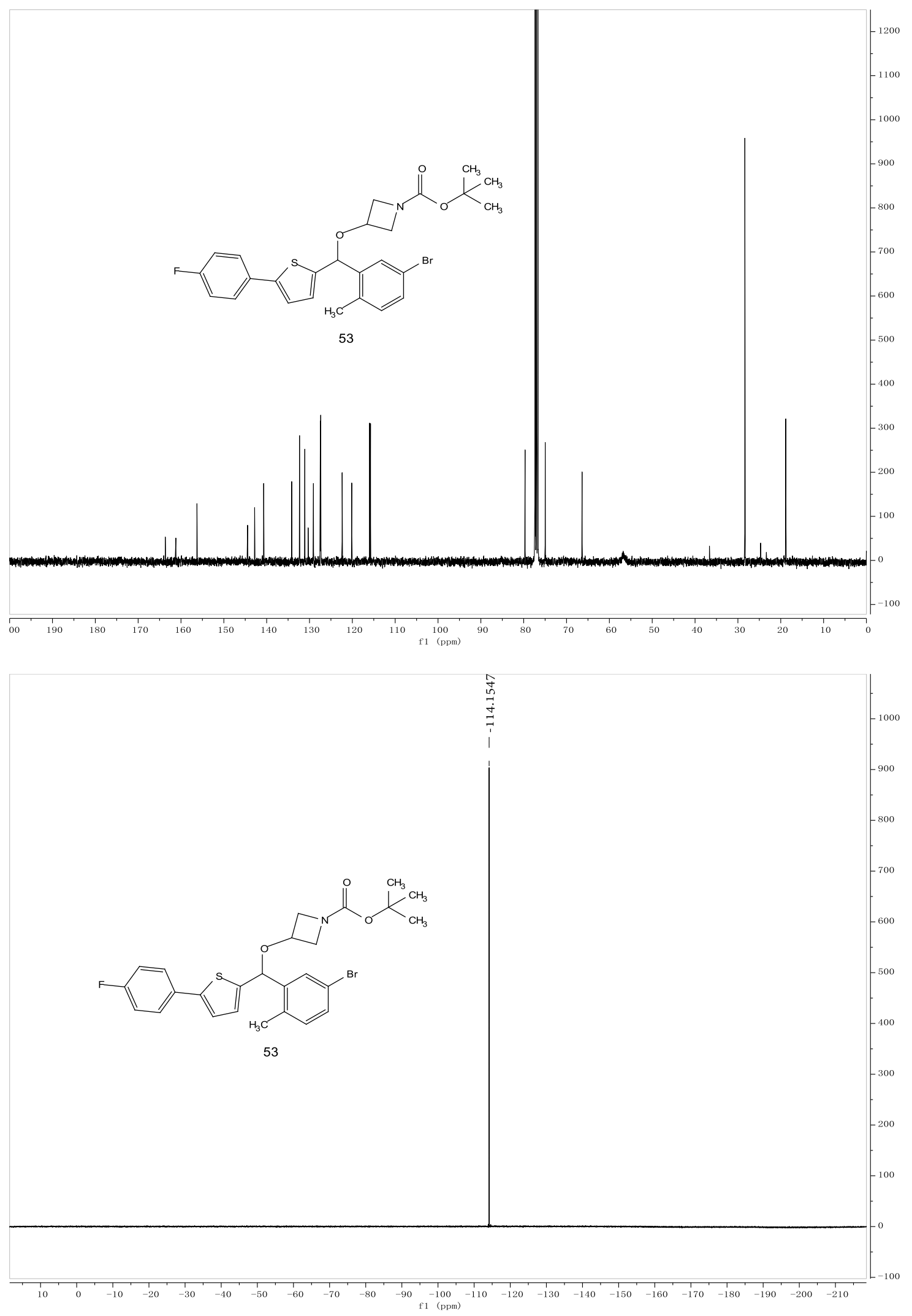



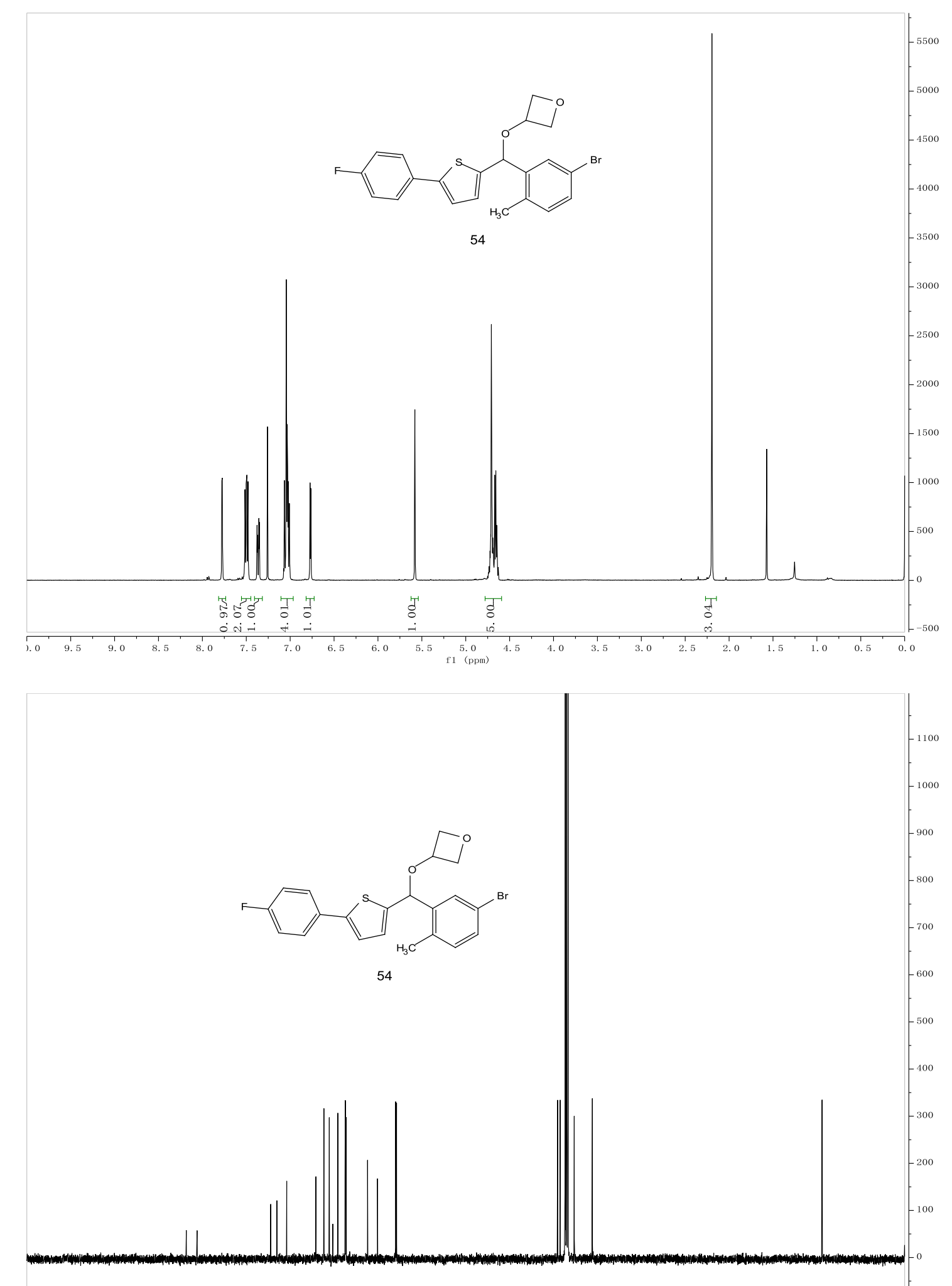

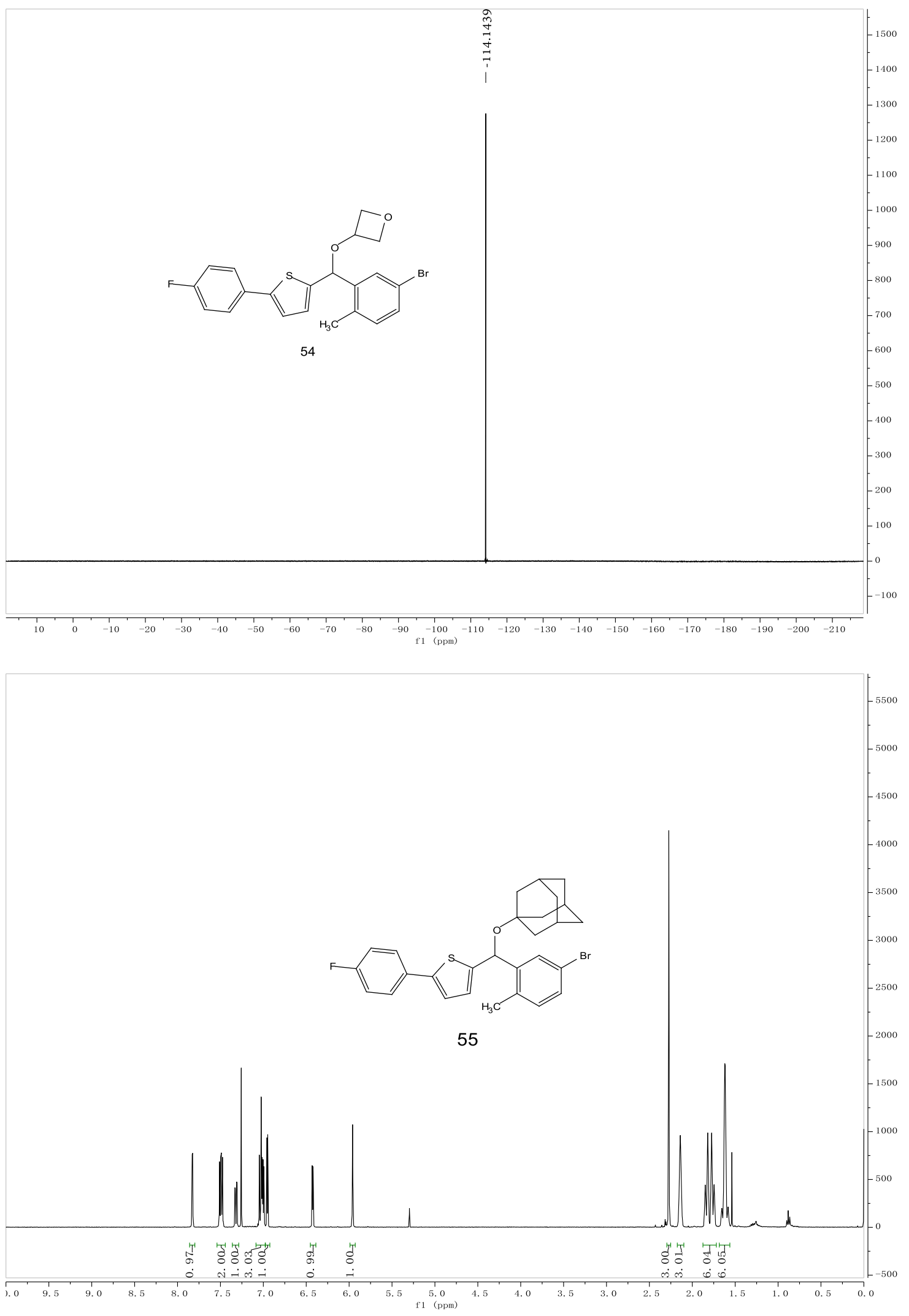

S94 


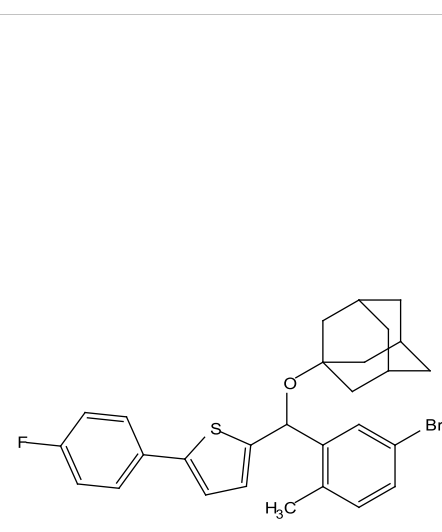

55
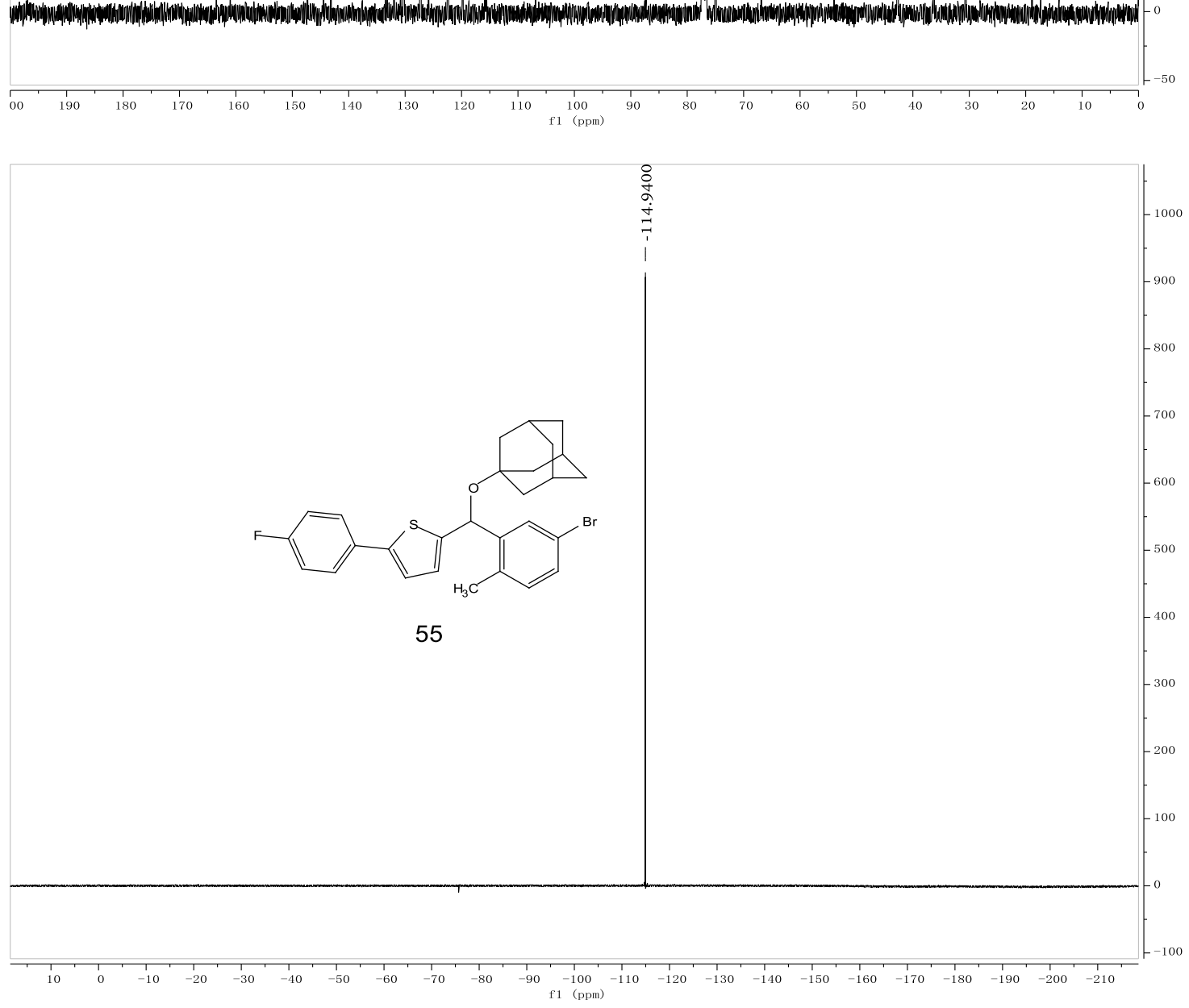

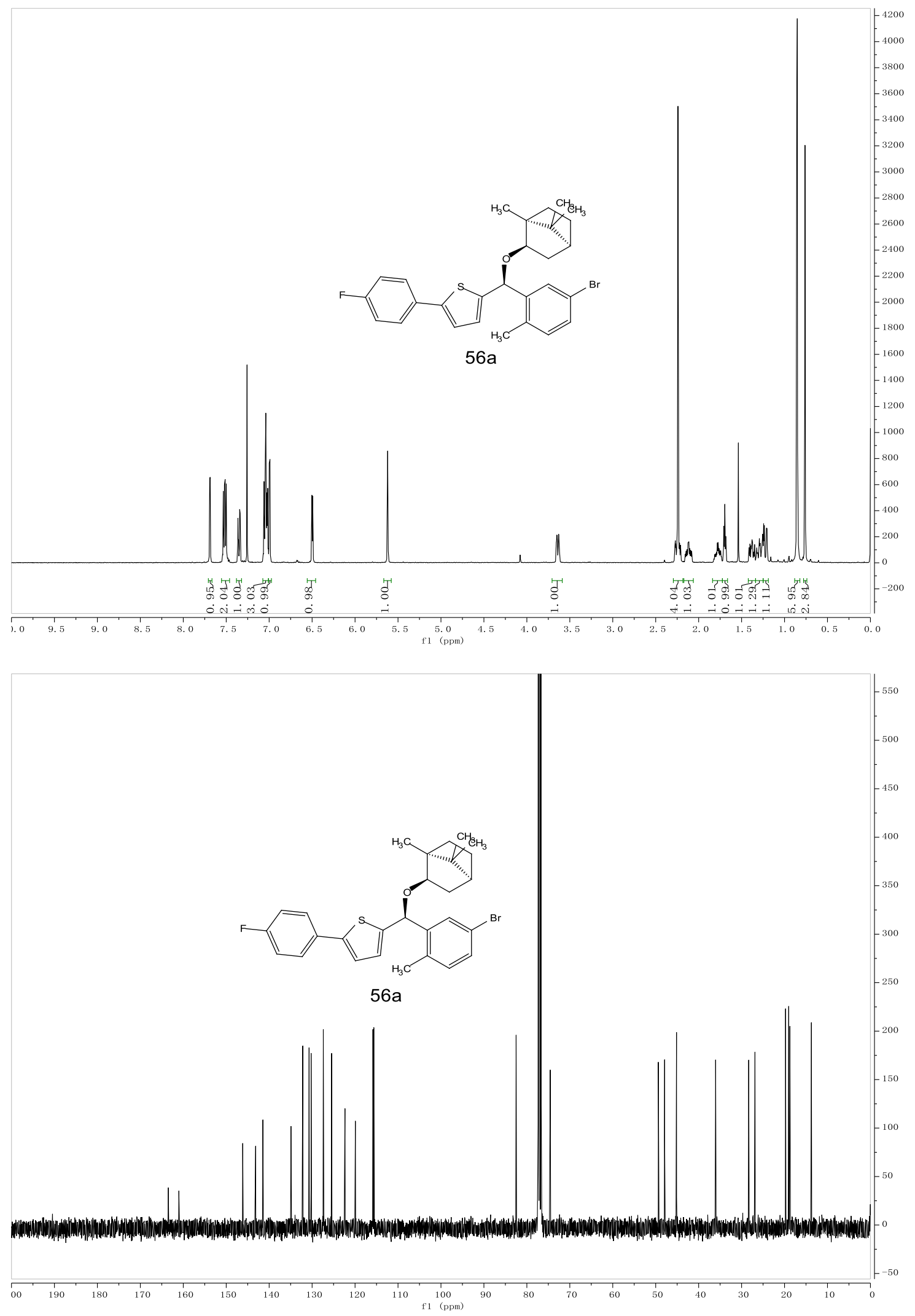

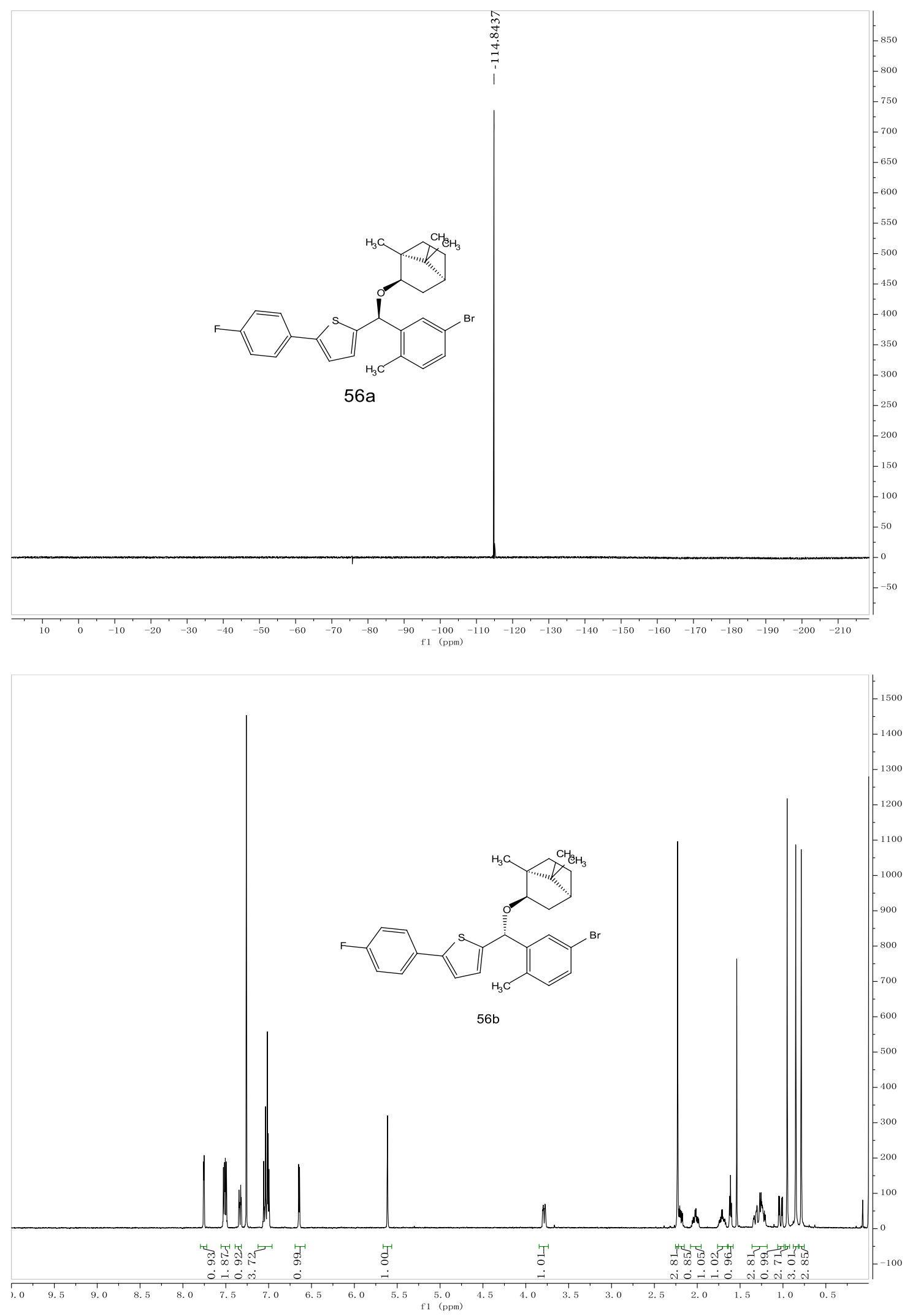


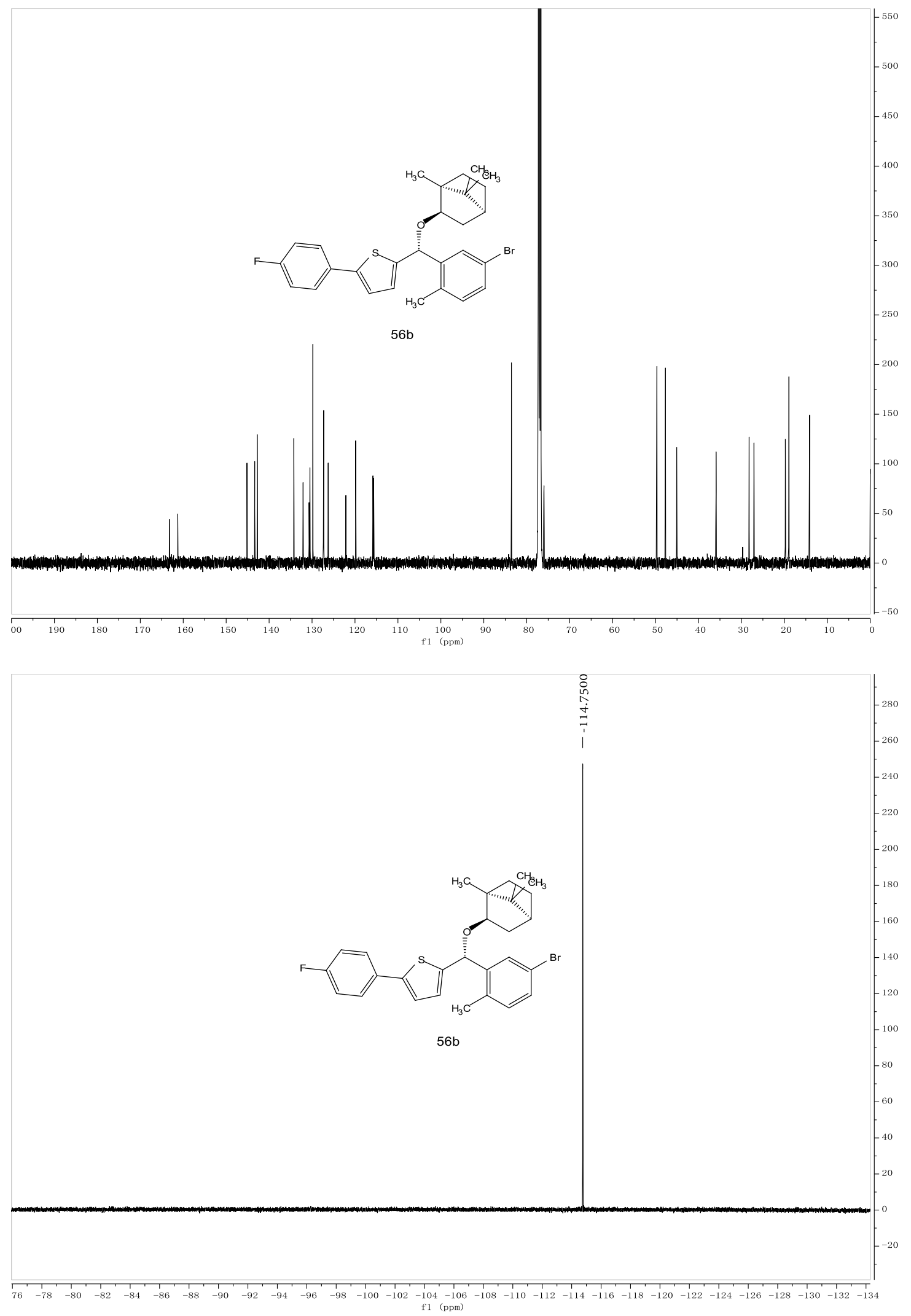




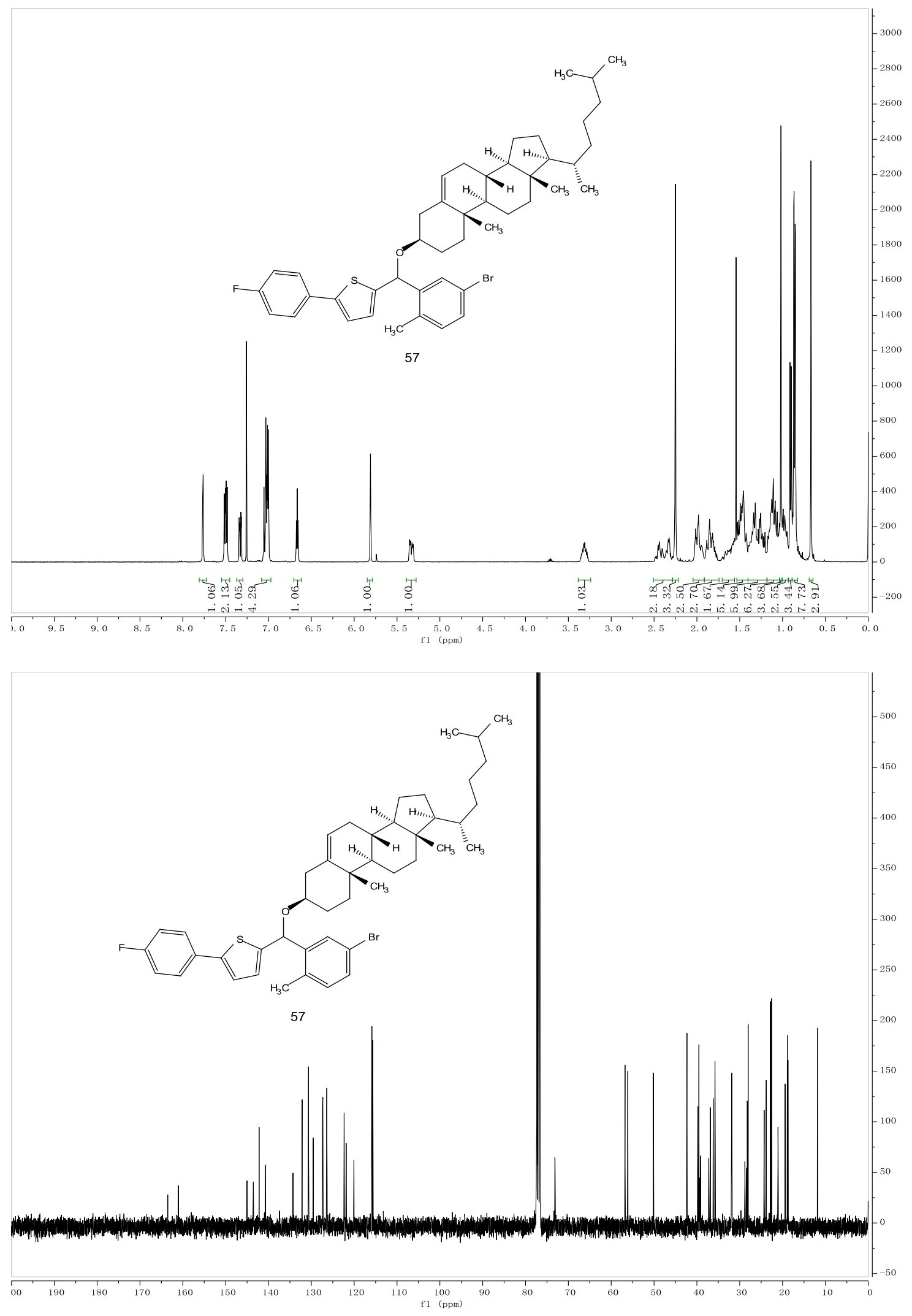



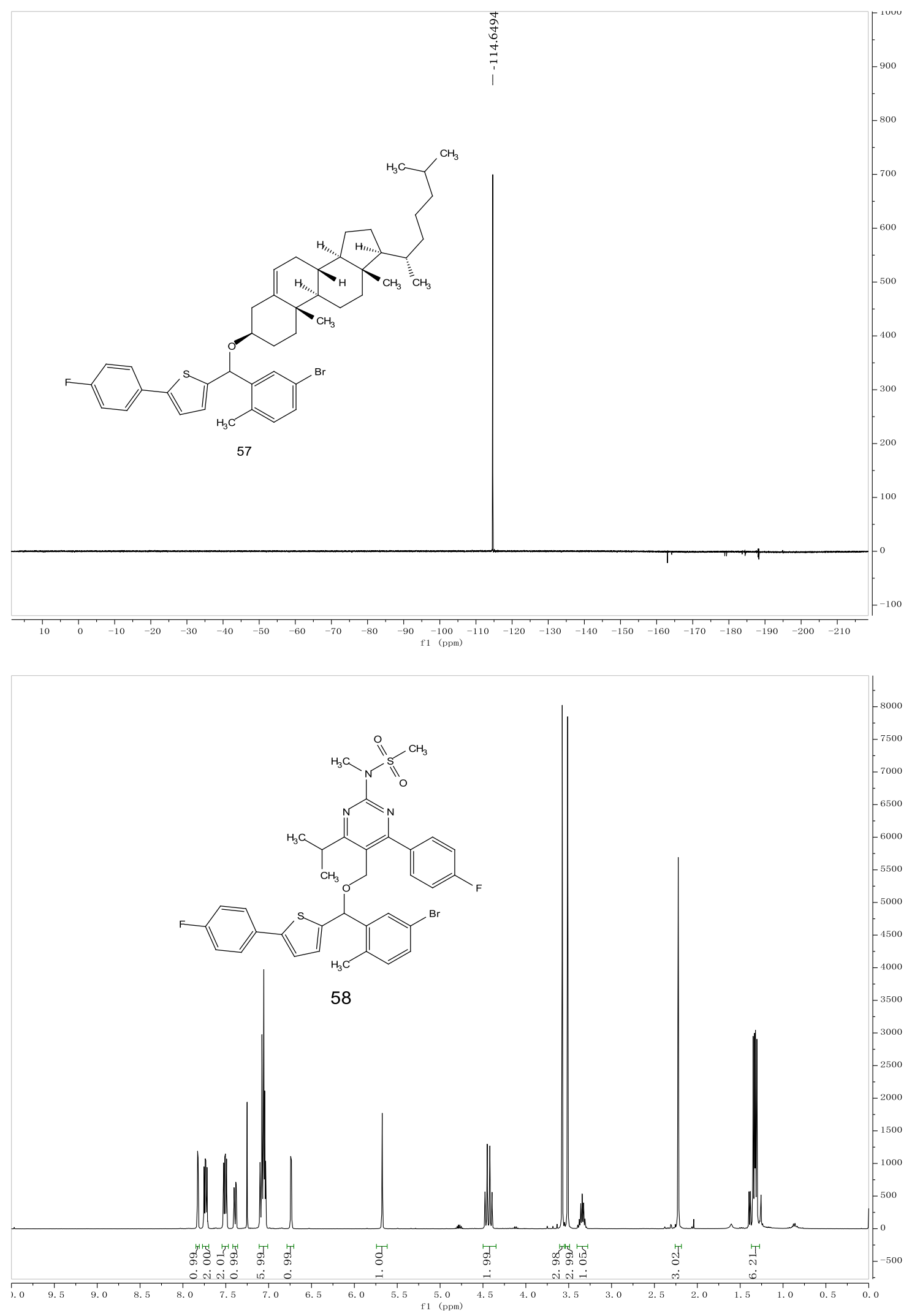


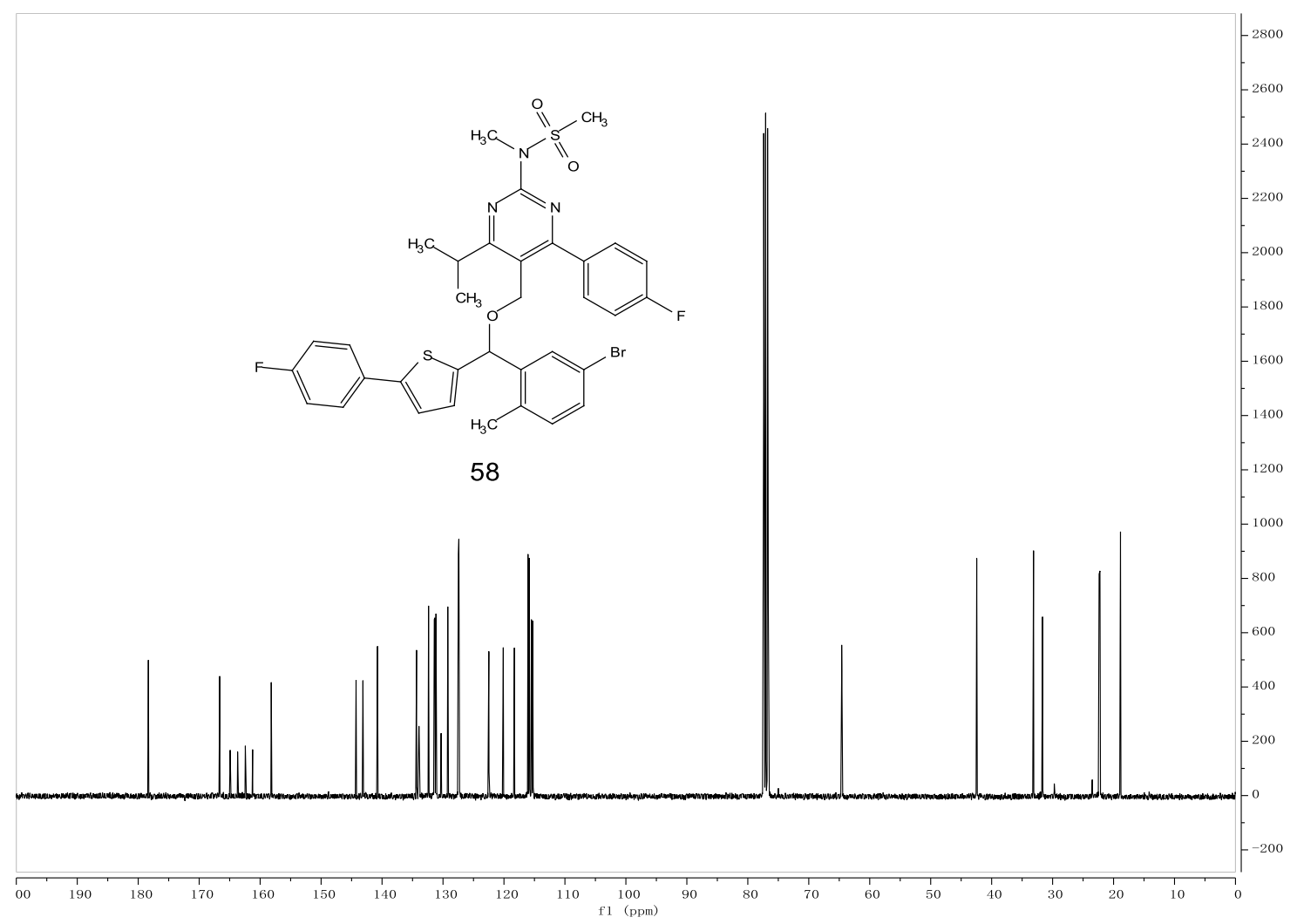




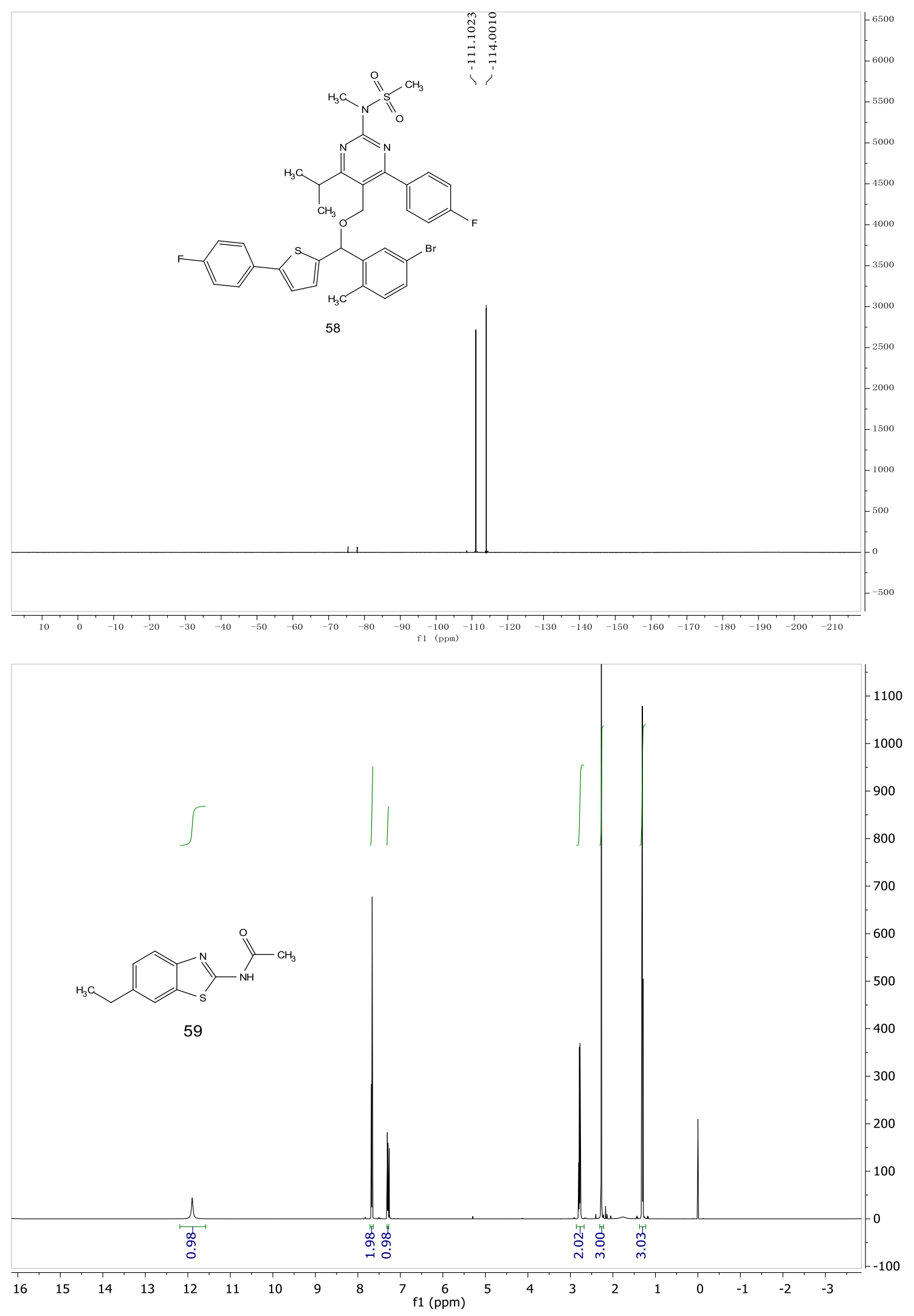




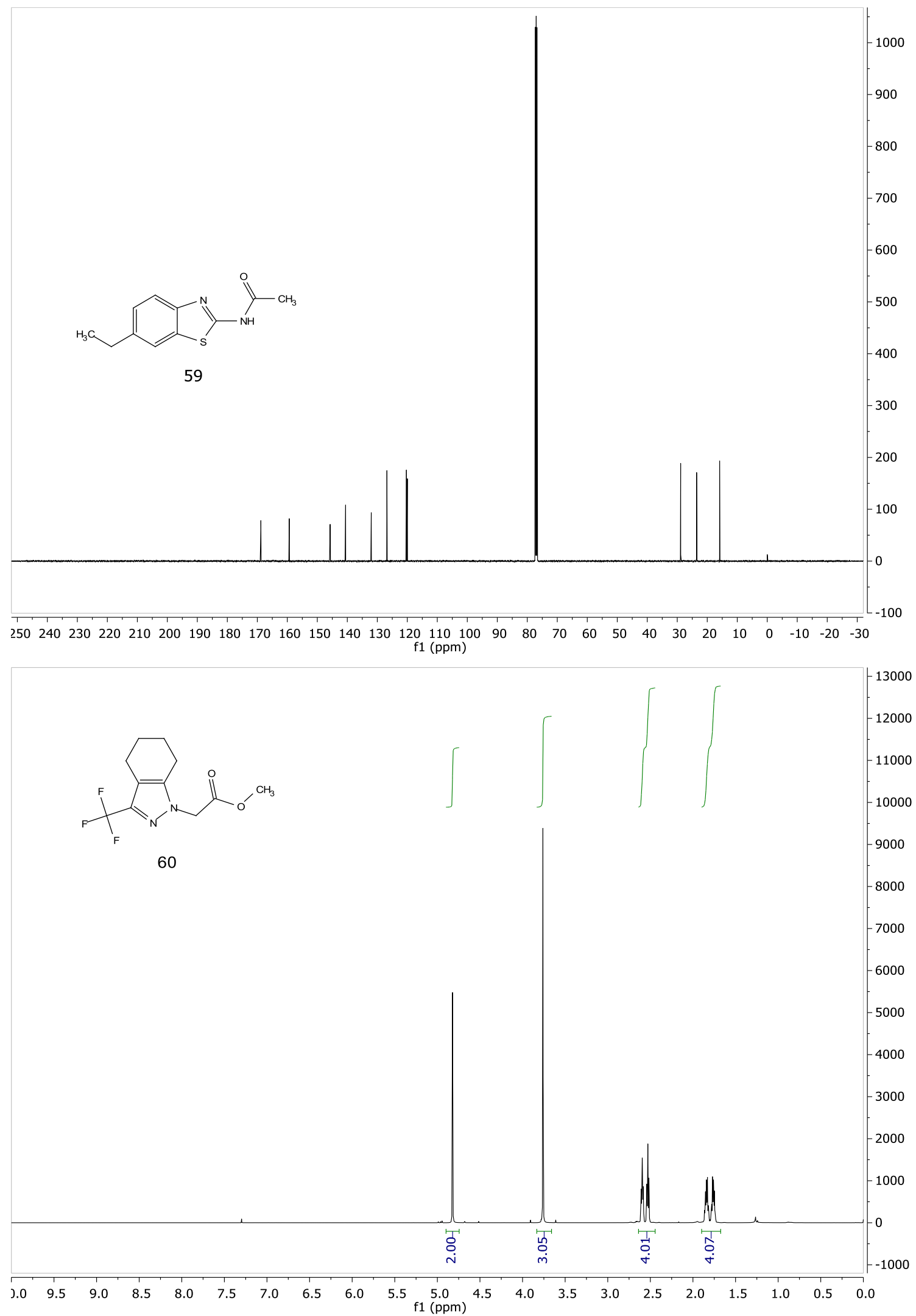




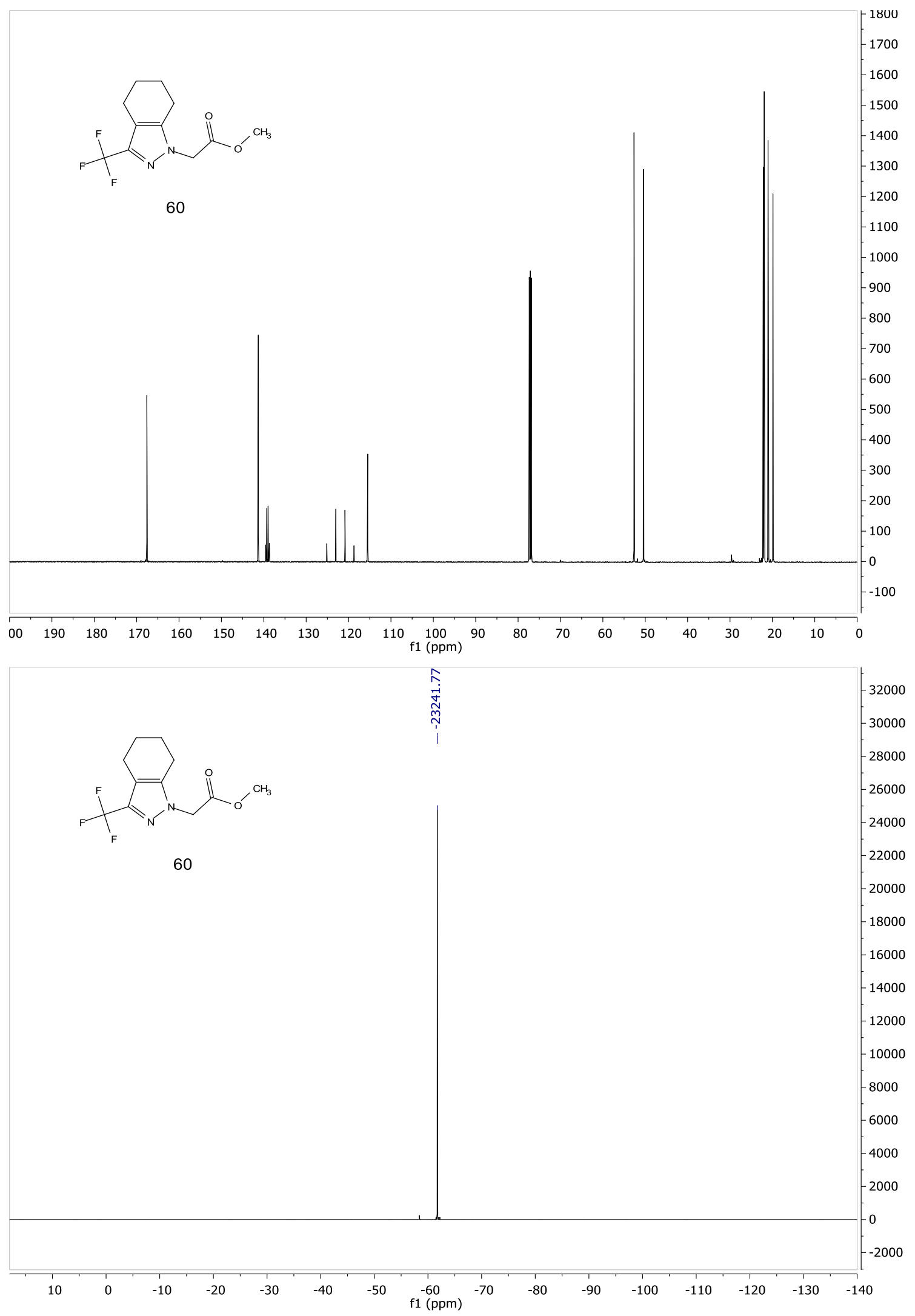




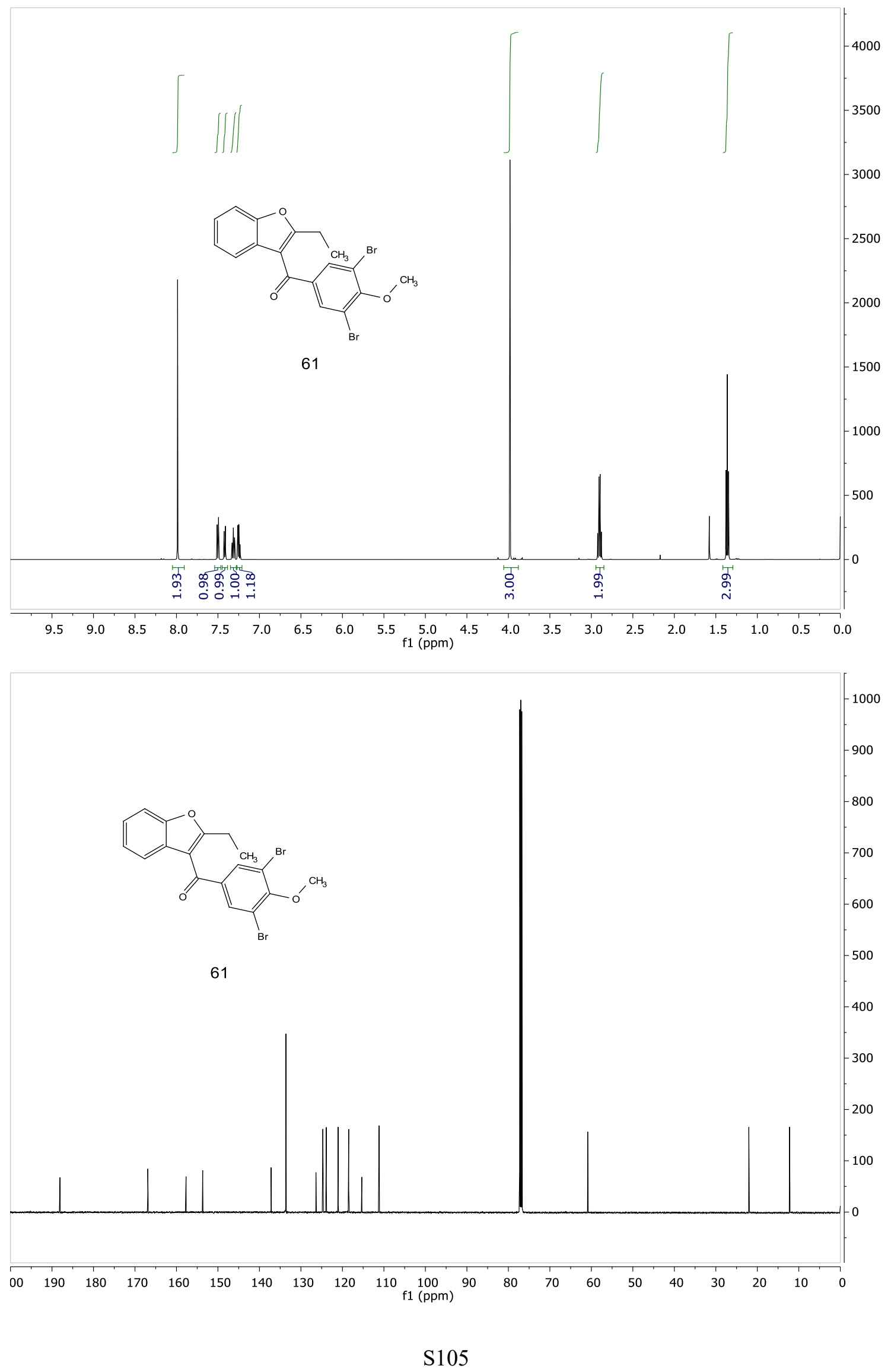


